

\section{Agama dan Bayang-Bayang Etis Syaikh Yusuf Al-Makassari}


Dr. Mustari Mustafa

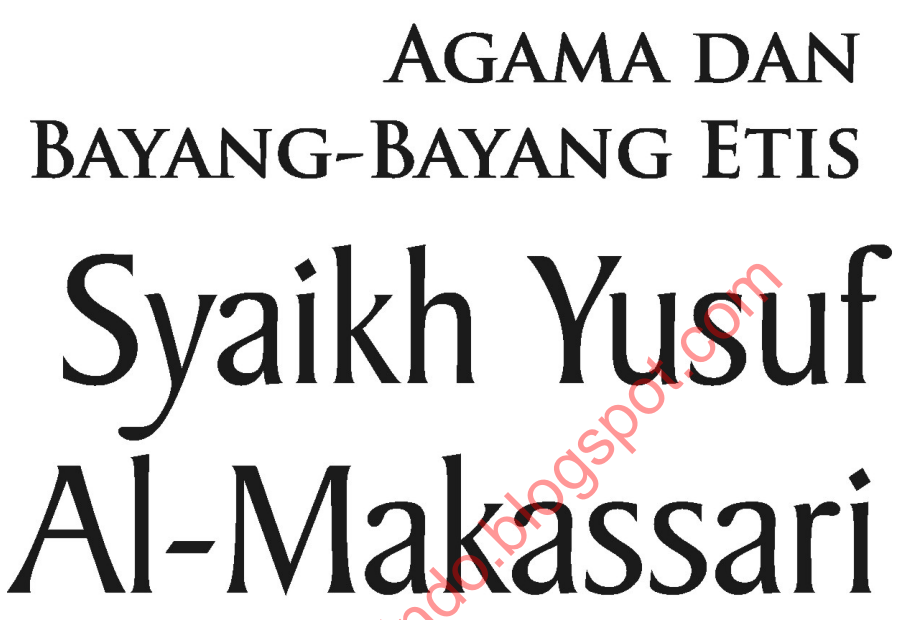

LKÍS 


\section{Agama dan Bayang-Bayang Etis Syaikh Yusuf Al- Makassari \\ Dr. Mustari Mustafa \\ (C) $L K i S, 2011$}

xii +206 halaman; 14,5 x $21 \mathrm{~cm}$

1. Syaikh Yusuf Al-Makassari 2. Etika religius

3. Dakwah pembebasan

ISBN: $979-25-5339-8$

ISBN 13: 978-979-25-5339-0

Editor: Yemmestri Enita

Penyelaras Akhir: Ahmala Arifin

Rancang Sampul: Haitami el-Jaid

Penata Isi: Santo

Penerbit \& Distribusi:

\section{LKiS Yogyakarta}

Salakan Baru No. 1 Sewon Bantul

Jl. Parangtritis Km. 4,4 Yogyakarta

Telp.: (0274) 387194

Faks.: (o274) 379430

http://www.lkis.co.id

e-mail: lkis@lkis.co.id

Cetakan I: Mei 2011

Percetakan:

PT. LKiS Printing Cemerlang

Salakan Baru No. 3 Sewon Bantul

Jl. Parangtritis Km. 4,4 Yogyakarta

Telp.: (0274) 417762

e-mail: elkisprinting@yahoo.co.id 


\section{PENGANTAR REDAKSI}

Buku ini menyajikan tokoh Syaikh al-Haj Yusuf Abu alMahasin Hadiyatullah al-Taj al-Khalwati al-Maqashshariy atau lebih dikenal sebagai Syaikh Yusuf Al-Makassari. Gelar syaikh yang disandang putra Makassar ini memiliki makna universal, yang dalam sejarah Nusantara berhubungan dengan ulama yang menguasai dunia tasawuf. Ia adalah tokoh historis yang mengembangkan ajaran etika religius dalam dakwahnya. Ajarannya bersumber dari kitab suci, tradisi, dan pemikiran tokohtokoh sejarah. Ia berhasil membawa Islam sebagai agama yang berkembang di dalam masyarakat yang majemuk, yang kaya akan pandangan-pandangan atau nilai-nilai tradisional.

Pijakan utama etika religius Syaikh Yusuf bersumber dari konsepsi Al-Qur'an tentang manusia dan kedudukannya di dalam alam semesta. Konsep teologi yang digunakan bercorak sufisme. Menurutnya, "hakikat manusia sebagai bayangan Tuhan di muka bumi" disebut sebagai konsep Al-Insan Al-Kamil. Konsep ini berfokus pada spiritualitas yang dapat mengantar manusia ke alam Ilahiah (alam ketuhanan), melalui potensi batin yang dimilikinya.

Selama hidupnya, Syaikh Yusuf telah menghasilkan puluhan karya/naskah, yang fokus utamanya adalah tasawuf dan etika dakwah. Di dalam karya-karyanya juga, Syaikh Yusuf mengulas tentang kaifiyat dzikir, yaitu dzikir yang mencakup etika religius 
lahir dan batin, sebagai pancaran kesempurnaan tauhid, makrifat, dan ibadah. Ia juga menjelaskan tentang makna kalimat tauhid $L a$ ilaaha illa Allah. Dalam kitab Mathalib Salikin misalnya, Syaikh Yusuf menekankan pentingnya memahami tauhid sehingga tidak mudah terjatuh pada kemusyrikan.

Syaikh Yusuf dikenal sebagai ulama pengembara untuk berguru kepada syaikh/ulama yang dikenal mumpuni. Setelah belajar agama di Makassar, kehausannya terhadap ilmu-ilmu agama dilanjutkan dengan mengembara ke daerah-daerah di Tanah Air terutama ke Banten dan Aceh, serta negara-negara Arab. Syaikh Yusuf meninggal di Cape Town Afrika Selatan setelah diasingkan oleh penjajah kolonial Belanda akibat dakwah dan perjuangannya bersama Sultan Banten. Selama empat tahun di Cape Town, Syaikh Yusuf berhasil membangun komunitas muslim yang solid, sehingga oleh pemerintah Afrika Selatan dinugerahi gelar pahlawan nasional.

Demikianlah poin-poin penting yang disuguhkan dalam kajian tentang Syaikh Yusuf ini. Dalam konteks dakwah Islam Indonesia, kajian tentang etika religius Syaikh Yusuf perlu dikembangkan, karena pesan dakwahnya mencerminkan nilai-nilai Islam yang toleran, damai, dan jauh dari tindakan-tindakan anarkis dan teror terhadap kelompok-kelompok masyarakat yang lain. Oleh karena itu, selayaknyalah pesan-pesan Islam yang damai ini menjadi bagian dari hidup kita dalam beragama, bermasyarakat, dan bernegara.

Kami sampaikan terima kasih kepada Bapak Mustari Mustafa yang telah mempercayakan karyanya ini untuk kami terbitkan. Dan, kepada sidang pembaca yang budiman, buku ini layak dikedepankan untuk mengisi kekeringan religiusitas kita dalam satu dekade terakhir ini. Selamat membaca! 


\section{PENGANTAR PENULIS}

Keterlibatan saya sebagai pengajar dan mubalig merupakan stimulus tersendiri dalam melakukan penelitian ini. Tokoh Syaikh Yusuf menjadi objek kajian karena beliau dikenal sebagai ulama, mubalig, sufi, ahli tarekat, dan pejuang yang menguasai dan mengamalkan ajaran Islam, baik lahir maupun batin. Metode dakwahnya yang adaptif sesuai dengan karakter masyarakat Indonesia yang plural serta kaya akan nilai-nilai tradisional. Etika religius Syaikh Yusuf bersumber dari Al-Qur'an, sunnah, dan filsafat, serta bercorak sufisme. Unsur utama pemikiran Syaikh Yusuf berpusat pada Tuhan, dunia, dan manusia. Menurutnya, manusia adalah bayangan Tuhan di muka bumi yang disebut sebagai Al-Insan alKamil. Dalam karyanya, Zubdatul Asrar, Syaikh Yusuf menekankan pentingnya etika terhadap Tuhan dan alam semesta.

Dari segi pengembangan dakwah, metode Syaikh Yusuf yang adaptif dapat dikatakan berbeda dengan model dakwah yang dilakukan oleh ulama lainnya, sehingga corak dakwahnya perlu dikembangkan dan diapresiasi. Model dakwah Syaikh Yusuf bercorak mengayomi dan mencerahkan, serta jauh dari pemaksaan dan anarkisme terhadap kelompok-kelompok lain.

Sebagai sufi yang memiliki keluasaan ilmu dan berkepribadian kuat, Syaikh Yusuf tak kenal lelah berjuang dalam menegakkan Islam dan melawan penjajahan, termasuk ketika diasingkan ke Cape Town Afrika Selatan. Tak heran, Presiden Nelson Mandella 
(ketika itu) pernah menyatakan bahwa Syaikh Yusuf merupakan salah satu insipiratornya dalam memperjuangkan kemerdekaan dan persamaan hak di Afrika.

Syaikh Yusuf meninggal di Cape Town Afrika Selatan pada tahun 1699. Tetapi keturunan Syaikh Yusuf hingga kini masih terus berdakwah mengembangkan Islam di Afrika. Dalam konteks dakwah di Indonesia, kajian etika religius Syaikh Yusuf dapat menjadi bahan acuan yang patut dikembangkan untuk merumuskan kembali paradigma-paradigma filsafat dakwah yang lebih baik untuk kehidupan keberagamaan yang toleran.

Hasil penelitian ini tentu tidak akan selesai tanpa dukungan berbagai pihak yang telah membantu proses penelitian hingga penulisan. Mereka tidak dapat saya sebutkan satu per satu, hanya doa dan ucapan terima kasih yang setinggi-tingginya, semoga mendapatkan balasan dari Allah Swt.

Terima kasih kepada Prof. Dr. Kaelan MS., Prof. Dr. Djoko Suryo, M.A., dan Prof Dr. Lasiyo, M.A., M.M. yang telah membimbing saya dalam menyelesaikan penelitian ini. Saya juga mengucapkan terima kasih kepada Rektor dan Direktur Sekolah Pascasarjana Universitas Gadjah Mada Yogyakarta, serta seluruh staf dan karyawan atas pelayanan akademiknya yang tulus. Kepada Dr. M. Mukhtasar Syamsuddin, Dekan Fakultas Filsafat Universitas Gadjah Mada yang telah memberikan saran dan waktu luangnya untuk berdiskusi. Juga kepada Prof. Dr. H.R. Soejadi, S.H. dan Prof. Dr. Syamsulhadi, selaku penilai dan penguji sekaligus guru yang telah memberikan evaluasi dan tanggapan kritis atas ide-ide dalam penelitian ini. Demikian juga kepada Prof. Imam Barnadib, M.A., Ph.D. (alm.), dan Dr. Saifan Nur, M.A., selaku Penguji serta guru yang arif. Dr. Abbas Hamami Mintaredja dan Dr. Joko Siswanto sebagai penanggung jawab program studi pascasarjana ilmu filsafat, yang telah memberikan bantuan untuk kelancaran penelitian ini. 


\section{Pengantar Penulis}

Tidak lupa juga ucapan terima kasih kepada rekan seperjuangan yang telah mengorbankan waktu dan tenaganya untuk berdiskusi: Dr. Jenderal (Purn.) AM. Hendropriyono, Dr. Saifur Rohman, Dr. Nurhidayat M. Said, dan Lukmanul Hakim Darusman, Ph.D.

Di lingkungan Universitas Islam Negeri Alaudin Makassar, saya mengucapkan terima kasih kepada rektor, dekan, dan jajaran pimpinan Fakultas Dakwah dan Komunikasi Universitas Islam Negeri Alauddin Makassar, yang telah memberikan kesempatan belajar kepada saya. Tak lupa juga kepada Prof. Dr. M. Sattu Alang, M.A., yang pernah menjadi Dekan Fakultas Dakwah dan Komunikasi Universitas Islam Negeri Alauddin, yang telah memberikan dorongan, semangat, dan menantang saya untuk melanjutkan studi.

Prof. Dr. Andi Rasdiyanah Amir dan Drs. Amir Said (alm.) merupakan sosok yang memiliki tempat tersendiri bagi saya karena mereka menjadikan penelitian ini kaya dengan analisis antropologis melalui penelitian yang telah dilakukannya. Tak lupa juga kepada Prof. Dr. M. Saleh A. Putuhena (alm.), Prof. Dr. Moch. Qasim Mathar, M.A., Prof. Dr. A. Qadir Gassing H.T., M.S., Prof. Dr. Ahmad M. Sewang, M.A., Dr. Sampo Seha, M.Sos.I., dan Mendiang Drs. Husain Sulaiman, M.Ag.

Saya juga ingin mengucapkan terima kasih kepada Bapak Sayun, M.Si. sekeluarga yang telah membagi ilmu serta pengalamannya; sebagai om, beliau sudah memberi warna tersendiri, kadang-kadang saya merasa proses studi serasa berjalan dengan kedekatan keluarga besar. Demikian juga keberadaan om, kakak, adik serta anak-anak lainnya di Yogyakarta yang telah membantu sehingga penulisan ini sampai pada tahap sekarang ini.

Saya harus menghaturkan penghargaan dan ucapan terima kasih kepada Bapak H. Mustafa Ibrahim serta Ibu Hj. Semia, orang 
tua saya yang sangat saya hormati dan cintai. Mereka telah merawat, mendidik, mendewasakan, mengajarkan huruf alif sampai yaa' hingga saya dapat menempuh jenjang pendidikan tertinggi.

Ketika hendak mengakhiri ucapan terima kasih ini, saya teringat mendiang Ibu Hanung yang merupakan sosok penuh cinta dan kasih, yang telah merawat dan mendidik saya hingga seperti sekarang ini. Kakak dan adik-adik tercinta, mendiang Musta'ami sek, Drs. H. Sahidin Mustafa S.H., M.H., sek, Siti Ratna sek, Muh. Tahir sek, Mahmud Yunus sek, Harifa Mustafa S.Ei. sek, Fatmawati, dan Sahrun, yang menjadi penyemangat tersendiri bagi saya selama penelitian dan penulisan.

Untuk Ibu Suwarni dan mendiang Bapak Sumargo beserta keluarga besar mertua di Semarang yang telah membantu kelancaran studi saya dari awal, dan senantiasa mendoakan agar proses penelitian dan penulisan ini selesai.

Akhirnya, saya harus menyebut istri saya tercinta, Diany Marganingsih S.Sos. MPA, serta putri-putriku tersayang, titipan Allah, yang telah memberi banyak kesempatan selama penelitian dan penulisan ini. Keceriaan dan suasana yang romantis senantiasa memberi motivasi dan doa yang tulus bagi saya.

Semoga karya ini menjadi jawaban yang memadai terhadap segala bantuan, bimbingan, dan pendidikan dari semua pihak yang terlibat. Hanya kepada Allah Swt. saya berserah diri dan memohon balasan yang setimpal kepada mereka semua.

Yogyakarta

Penulis 


\section{DAFTAR ISI}

Pengantar redaksi $\$ \mathrm{v}$

Pengantar penulis vii

Daftar Isi $\$$ xi

BAB I

PENDAHULUAN $\rightarrow 1$

\section{BAB II}

BIOGRAFI SYAIKH YUSUF DAN KARYA-KARYANYA $\approx 13$

A. Biografi Singkat dan Latar Belakang Pemikiran Syaikh Yusuf $\rightarrow 19$

1. Kelahiran 19

2. Pendidikan 22

a. Banten 24

b. Aceh $\$ 25$

c. Yaman, Hijaz, Syiria, dan Turki $\$ 26$

d. Makassar, Banten, dan Cape Town (Afrika Selatan) $\$ 27$

3. Kepribadian Syaikh Yusuf dan Guru-gurunya 29

B. Karya-karya Syaikh Yusuf 32

C. Tokoh-tokoh yang Berpengaruh dalam Karya Syaikh Yusuf $\$ 38$ 


\section{BAB III}

BASIS PEMIKIRAN ETIKA RELIGIUS SYAIKH YUSUF 943
A. Syariat $\$ 45$
B. Tarekat 52
C. Hakikat 58
D. Makrifat 65

\section{BAB IV}

UNIVERSALISME PESAN ETIS DALAM KARYA SYAIKH YUSUF $\rightarrow 83$
A. Pesan Ilahi dalam Teks Keagamaan dan Universalisme Islam dalam Karya-karya Syaikh Yusuf 94
B. Etika Religius Syaikh Yusuf dalam Dakwah 97

\section{BAB V}

\section{REFLEKSI TEORETIS ETIKA RELIGIUS}

SYAIKH YUSUF 109
A. Refleksi dalam Konteks Ke-Indonesiaan \$ 110
B. Rekonstruksi dan Tawaran Metodologis \$ 116

\section{BAB VI \\ PENUTUP क 167}

DAFTAR PUSTAKA 9173

INDEKS $\rightarrow 199$

BIODATA PENULIS 205 


\section{Bab I \\ PENDAHULUAN}

Buku ini merupakan hasil penelitian yang dilatarbelakangi oleh kerisauan penulis terhadap krisis keindonesiaan pascareformasi, yang berakibat pada rapuhnya kondisi sosial, ekonomi, dan politik, serta krisis moralitas yang melanda sebagian besar masyarakat Indonesia.

Sikap dan perilaku yang menyimpang bisa dijumpai dalam kehidupan bernegara. Tata hukum dan tata negara disinyalir cenderung berpihak pada kepentingan penguasa. Tampaknya, sistem demokrasi yang ada hanya dinikmati oleh penguasa. Dalam konteks ini, korupsi, kolusi, nepotisme, pelanggaran hukum, dan pelecehan kemanusiaan oleh penguasa didesain dengan sistem dan mekanisme yang samar di mata publik. Padahal, Indonesia diklaim memiliki koridor hukum dan landasan etika (agama) yang jelas. Di sisi lain, Indonesia dikenal sebagai negara dengan penganut agama (Islam) terbesar, sehingga perilaku masyarakatnya dinilai sebagai representasi ajaran agama yang dianutnya.

Kenyataannya, hukum dan peraturan ternyata tidak menjamin terciptanya perilaku etis dalam kehidupan berbangsabernegara. Banyaknya aturan tidak mengurangi pelanggaran yang terjadi. Secara tekstual dan normatif, aturan dan perundangundangan serta agama yang memuat ajaran tentang etika, menolak sikap dan perilaku tidak etis, sehingga di dalamnya termuat sanksi 
dan ancaman terhadap sikap dan perilaku tidak etis. Tampaknya realitas kehidupan berbangsa-bernegara tidak menghargai anjuran-anjuran etika yang ada.

Bangsa Indonesia telah merumuskan etika yang mengatur hubungan manusia dengan Tuhan dan hubungan manusia dengan manusia dalam falsafah negara, yakni Pancasila. Pancasila sarat dengan nilai-nilai luhur dan tidak bertentangan dengan nilai-nilai agama yang ada. Etika di dalam filsafat Pancasila tidak sama dengan etika filsafat sekuler. Nilai-nilai Pancasila sarat dengan etika, dirumuskan berdasarkan nilai-nilai universal dari beberapa agama yang ada di Indonesia, sehingga permasalahan manusia tercakup dalam kelima sila tersebut. ${ }^{1}$

Sistem demokrasi di era globalisasi telah menimbulkan perubahan yang mempengaruhi nilai-nilai etika yang berlaku di masyarakat. Perubahan yang terjadi juga mempengaruhi perkembangan kebudayaan, yang seringkali membongkar etika yang dianut masyarakat. Alam kebebasan yang dibungkus sistem demokrasi, menurut filosof Yunani kuno, Plato, tidak menjamin masa depan manusia yang beradab. Sistem demokrasi memberikan kebebasan berlebih kepada setiap orang untuk mengejar kepentingannya sendiri-sendiri. ${ }^{2}$ Standar kepantasan sosial turut berubah. Apa yang sebelumnya dianggap tidak pantas secara sosial, sekarang dianggap pantas karena banyak masyarakat yang menerimanya. Penerimaan masyarakat terhadap globalisasi dengan unsur modernisasinya cenderung dianggap sebagai gaya hidup dan ukuran kemajuan. ${ }^{3}$ Bahkan ketidakadilan, ketidakpedulian etika sosial dan keagamaan, hukum dalam bermasya-

Lasiyo dan Yuwono, Pancasila; Pendekatan secara Kefilsafatan (Yogyakarta: Liberti, 1985), hlm. 16.

2 Retno Kristy (ed.), Plato: Pemikir Etika dan Metafisika (Jakarta: Gramedia, 2007), hlm.57.

3 Fuad Hassan, Stadium Generale (Bandung: Pustaka Jaya, 2001), hlm.53-144. 


\section{Pendahuluan}

rakat, baik antarnegara maupun di dalam negara dinilai tidak mempunyai motivasi agama, tetapi lebih pada wilayah ekonomi. Namun, justifikasi agama digunakan oleh sebagian kelompok bagi tindakan yang melanggar etika sosial dan keagamaan. ${ }^{4}$

Sikap dan perilaku saling mengancam yang dilakukan oleh negara-negara yang terlibat perang, merupakan pelanggaran etika, dari penghilangan nyawa orang tidak bersalah, perampasan hakhak masyarakat, baik moril maupun materil. Levinas menyatakan bahwa, kebangkrutan etika ditandai dengan pembantaian manusia yang tidak berdosa. Etika yang mengajarkan sebuah kesadaran tentang hidup bersama dengan orang lain, memandang kehadiran orang lain sebagai nilai-nilai yang tidak mungkin ditabrak, dan seharusnya manusia tunduk dengan nilai-nilai tersebut. ${ }^{5}$

Hal penting lainnya adalah munculnya kekerasan atas nama agama yang oleh sebagian kalangan disebabkan oleh sikap putus asa dan kekalahan atas penindasan yang dilakukan oleh pihak yang kuat. Untuk mengatasinya, baik oleh negara maupun kelompok masyarakat, harus melalui perjuangan ideologis, kritis, dan konstruktif yang berlanđáskan pada etika keagamaan universal. ${ }^{6}$

Kekerasan atas nama agama di Indonesia, dapat dijumpai dalam berbagai kasus, misalnya penyerbuan oleh massa anti Ahmadiyah, gerakan Front Pembela Islam (FPI), pemboikotan aliran-aliran sempalan, aksi-aksi untuk solidaritas Palestina, aksiaksi anti-Barat, Yahudi, dan Amerika atas dasar sikap dan kebijakan negara-negara tersebut, serta kasus kecurigaan antara kelompokkelompok penganut agama. Simbol agama tampil dalam wajah demonstrasi massa yang brutal dan tanpa sasaran yang logis,

4 Rafik Issa Beekun, Islamic Business Ethics (Yogyakarta: Pustaka Pelajar, 2004), hlm. 63-64.

5 Armada Riyanto, "Etika Mati di Aushcwitz dan Gaza", Kompas, 17 Januari 2009.

6 Ibid., hlm. 71-72. 
menyebabkan posisi dan kedudukan agama dihubung-hubungkan dengan logika bahwa agama berada di balik tindakan-tindakan tersebut, dan karenanya agama menjadi sistem yang lumpuh, bahkan mungkin hampir mati secara kultural (the end of culture). Ironisnya, negara tampak tidak berdaya dalam menekan konflikkonflik kekerasan. Bahkan tidak jarang pejabat yang berwenang mengeluarkan pernyataan yang seakan-akan menjustifikasi sebagian aksi-aksi kekerasan tersebut.7 Dalam konteks ini, fungsi agama bukan merupakan elemen yang pasif dalam proses perubahan sosial. Seharusnya agama mampu memainkan peranan yang penting bagi konsolidasi sebuah struktur baru. Dalam sejarah politik, telah ditunjukkan kekuatan agama yang dapat menjadi elemen pemicu yang efektif untuk menggerakkan perubahan politik, bahkan revolusi. ${ }^{8}$

Kontradiksi antara ajaran yang baik/benar di dalam agama dengan realitas kehidupan masyarakat, akhirnya memunculkan pertanyaan yang berkaitan dengan sejarah: bagaimana agama dikembangkan di dalam masyarakat? Keberhasilan ajaran-ajaran agama untuk menegakkan etika, dalam sejarahnya, tidak dapat dipungkiri. Akan tetapi, faktor-faktor kegagalannya juga perlu dicermati, terutama pada saat ini. Tampaknya agama belum memperlihatkan caranya dalam mengatasi krisis tersebut. Yang terjadi justru banyak pertentangan yang disertai dengan klaim kebenaran (truth claim) oleh kelompok-kelompok agama sendiri, sehingga mencederai ajaran agama yang secara historis dikembangkan melalui misi etis.

Pemikiran dan ajaran tentang etika dari berbagai sumber, dapat dianggap sebagai ajaran tasawuf yang mengandung kritik

\footnotetext{
Azyumardi Azra, "Radikalisme Kelompok Islam di Indonesia", Kompas, 27 Juli 2007.

8 Sunyoto Usman, Pembangunan dan Pemberdayaan Masyarakat (Yogyakarta: Pustaka Pelajar, 1998), hlm.185.
} 


\section{Pendahuluan}

sosial, mengedepankan inspirasi, dan menjadi sumber energi untuk melakukan perubahan. Oleh karena itu, tasawuf dapat dijadikan koreksi etis terhadap dakwah Islam dengan kendala-kendala yang cukup memprihatinkan bagi perkembangan Islam dan masyarakat Islam.

Beberapa kendala tentang moralitas bangsa antara lain: Pertama, krisis moralitas yang ditunjukkan oleh banyaknya organisasi dakwah dan individu yang berorientasi pada kepentingan kelompok dan anggotanya. Kedua, di lingkungan umat Islam sendiri, dakwah sebagai aspek yang melekat dalam pengembangan dan pengamalan agama, kurang memiliki citra yang kuat dalam menerapkan nilai-nilai filosofis dakwah rasul, Sebab, bentuk dakwah Islam di Indonesia cenderung apatis-skeptis, retoris, dan show of force.

Etika religius menjadi tawaran untuk membebaskan manusia dari segala bentuk keterbelakangan di satu sisi, dan mengembangkan struktur sosial masyarakatuntuk menciptakan keadilan dan kebajikan, di sisi lain. ${ }^{9}$ Selain itu, beberapa macam etika yang perlu mendapatkan perhatian térkait dengan kehidupan beragama dan bermasyarakat adalah etika sosial, ${ }^{10}$ etika profesi hukum, ${ }^{11}$ etika lingkungan, ${ }^{12}$ etika bisnis, ${ }^{13}$ etika kebidanan dan hukum kesehatan, ${ }^{14}$

\footnotetext{
9 Asghar Ali Engineer, Islam and Liberation Theology (Yogyakarta: Pustaka Pelajar, 2003), hlm. 11.

10 JennyTeichman, Social Ethics: A Student's Guide (terj.) (Yogyakarta: Kanisius, 1998).

${ }^{11}$ Abdul Kadir Muhammad, Etika Profesi Hukum (Bandung: Citra Aditya Bakti, 2006).

12 A.Sony Keraf, Etika Lingkungan (Jakarta: Kompas Media Nusantara, 2006).

${ }^{13}$ Dochak Latif, Etika Bisnis: Antara Norma dan Realita (Surakarta: Muhammadiyah University Press, 2006).

${ }^{14}$ Soepardan, Suryani, dan Dadi Anwar, Etika Kebidanan dan Hukum Kesehatan (Jakarta: Penerbit buku Kedokteran, EGC, 2005).
} 
etika customer service, etika bisnis dalam Islam, ${ }^{15}$ dan etika politik dan kekuasaan. ${ }^{16}$ Contoh-contoh etika tersebut menunjukkan bahwa dimensi etika mencakup seluruh aspek kehidupan.

Kehadiran etika religius sangat penting karena adanya proses partikularisasi nilai-nilai keagamaan dalam zaman yang terus berubah. Secara umum, semua agama, khususnya Islam menekankan pentingnya etika religius dalam kehidupan sehari-hari. ${ }^{17}$ Dalam literatur-literatur etika dasar, ada empat alasan tentang pentingnya etika religius. Pertama, masyarakat yang semakin pluralistik, termasuk aspek moral. Banyak ajaran moral saling berhadapan dan seringkali bertentangan, karena adanya truth claim. Kedua, masa transformasi di bawah hantaman gelombang modernisasi. Transformasi di semua bidang menantang nilai-nilai budaya, sehingga etika religius diperlukan agar manusia tidak kehilangan orientasi. Ketiga, proses perubahan sosial, budaya, dan moral tidak jarang dimanfaatkan oleh pihak-pihak tertentu untuk memancing di air keruh. Keempat, bagi kalangan agamawan, etika religius berfungsi untuk menemukan dasar kekokohan iman.

Ajaran-ajaran etika religius digali dari berbagai sumber, antara lain kitab suci, tradisi, ajaran atau pemikiran tokoh. Kajian ini membahas pemikiran Syaikh Yusuf al-Makassary, salah satu tokoh besar dalam sejarah Islam Indonesia. Jejaknya meliputi Sulawesi Selatan, Jawa Barat, hingga Arabia, Sri Lanka, dan Afrika Selatan. Dia adalah tokoh historis yang juga dikenal sebagai da'i, ulama, ahli tarekat, dan sufi besar yang telah mencapai puncak pendakian spiritual tertinggi dalam suluk-nya. Syaikh Yusuf juga tampil dalam peran sosial-politik, dengan menjadi mufti Kerajaan

\footnotetext{
${ }^{15}$ Ahmad Mustaq, Business Ethics in Islam, (Jakarta: Pustaka al-Kautsar, 2006).

${ }^{16}$ Haryatmoko, Etika Politik dan Kekuasaan (Jakarta: Kompas, 2003).

${ }^{17}$ M. Amin Abdullah, Studi Agama, Normativitas atau Historisitas? (Yogyakarta: Pustaka Pelajar, 2004).
} 


\section{Pendahuluan}

Islam Banten, dan pejuang dengan patriotisme besar melawan penjajah di Nusantara. Bahkan ketokohan Syaikh Yusuf telah melampaui batas negara. ${ }^{18}$ Selain itu, Syaikh Yusuf berhasil membawa Islam sebagai agama yang maju di dalam masyarakat yang plural secara agama, suku, etnis, dan nilai-nilai tradisional.

Melekatnya dakwah Islam dengan tradisi, strata, dan latar belakang masyarakat pada masa Syaikh Yusuf merupakan faktorfaktor penting dalam dakwah yang dikembangkannya. Perbedaan status sosial (ekonomi, pendidikan, lingkungan tempat tinggal) telah menyebabkan intensitas dan derajat pemahaman keagamaan menjadi berbeda atau beragam. Bahkan latar belakang pendidikan yang tidak sama, baik dari jenis pendidikan, perlakuan pendidikan (treatment), dan faktor status pelaku dakwah, yakni menyangkut kapasitas, kapabilitas, kualitas, dan profesionalitas, secara personal ataupun institusional, turut mempengaruhi kesadaran dan partisipasi keberagamaan masyarakat. ${ }^{19}$

Kajian dalam buku ini menggunakan perspektif etika yang di dalamnya terkandung nilai-nilai universal, sehingga relevan dan aktual bagi kehidupan masyarakat Indonesia yang sedang menghadapi krisis multi-dimensi. Sejauh ini, kajian terhadap ajaranajaran etika religius Syaikh Yusuf belum banyak dilakukan, terutama relevansinya dengan dakwah Islam di Indonesia. Oleh karena itu, kajian ini berusaha memberikan deskripsi yang berbeda dalam metode analisis dan heuristik. Analisis filosofis dari sudut pandang teori etika religius ditambah teori etika filsafat adalah penelitian baru dalam kajian pemikiran Syaikh Yusuf. Beberapa

18 Tahun 2005, pemerintah Afrika Selatan menetapkan Syaikh Yusuf sebagai pahlawan nasional Afrika Selatan. Lihat, Solichin Salam, Syaikh Yusuf "Singa dari Gowa" (Ulama Kaliber Internasional) (Jakarta: Yayasan Pembina Generasi Muda Indonesia Bekerja sama dengan Gema Salam, 2004), hlm.55.

${ }^{19}$ Mustari, "Studi Metodologi Dakwah Yayasan Paramadina Jakarta". Skripsi (1995) tidak diterbitkan, Fakultas Dakwah dan Komunikasi, UIN Alauddin Makassar. 
penelitian memang telah dilakukan oleh peneliti lain, namun kajian mereka lebih difokuskan pada aspek anthropological approach, historical approach, filological approach, dan sociological approach. Sedangkan aspek philosophical approach belum diungkap sama sekali. Karena itulah kajian dalam buku ini difokuskan pada aspek tersebut.

Karya-karya yang mengkaji Syaikh Yusuf, di antaranya adalah: Takutlah Pada Orang Jujur, Mozaik Pemikiran, karya Mangemba, yang memaparkan riwayat hidup Syaikh Yusuf sebagai pahlawan nasional, penyebar agama Islam, dan pejuang hak asasi manusia. Perbedaannya dengan karya ini terletak pada objek formal dan metode penelitiannya. Objek formal karya bukan karyakarya Syaikh Yusuf, melainkan tulisan mengenai Syaikh Yusuf oleh masyarakat, tempat asal Syaikh Yusuf.

Karya filologi lain yang fokus pada satu karya Syaikh Yusuf adalah "Menyingkap Intisari Segala Rahasia" oleh Lubis. Penelitian ini merupakan penelitian sejarah kelahiran dan filologi. Kajian lain tentang Syaikh Yusuf yang bersifat sejarah dan antropologis adalah kajian yang dilakukan oleh Hamid yang menitikberatkan pada kajian deskriptif-antropologis.

Karya Darusman (2008) yang berjudul Jihad in Two Faces of Shariah, Islamic Jurisprudence and Islamic Sufism (Fiqh and Tasawwuf) Case Studies of Syaikh Yusufal-Maqassary and Syaikh Daud al-Fatani of Thailand (Jihad dalam Dua Wajah Syariah, Fiqh Islam dan Tasawuf Islam: Studi Kasus Syaikh Yusuf al-Makassari dan Syaikh Daud al-Fatani). Karya ini membahas konsep jihad dalam syar'iat Islam, yaitu konsep jihad dalam fiqh dan tasawuf serta konsep syar'iat Islam, dengan pendekatan sejarah secara komprehensif. Artinya, pembahasannya tidak hanya berdasarkan urutan sejarah an sich, tetapi juga menyentuh aspek-aspek teologis, sosiologis, dan filosofis serta analisis yang melatar- 


\section{Pendahuluan}

belakangi munculnya konsep-konsep tersebut dalam tradisi Islam. Selain itu, karya ini juga membahas perkembangan konsep-konsep tersebut dalam dinamika perkembangan pemikiran Islam.

Peneliti luar yang mengkaji Syaikh Yusuf adalah B.F. Matthes yang berjudul "Boeginesche en Makassarsche Legenden" (dalam BKI Vierde Volgreeks deel 1885). Penelitian yang bersifat deksriptif-historis mengemukakan bahwa Syaikh Yusuf lahir di Gowa setelah berkembangnya agama Islam. Syaikh Yusuf atau disebut juga Tuang Salamaka atau yang diberkati, adalah seorang wali yang dikeramatkan. Matthes menceritakan bahwa setelah kembali dari menunaikan haji, Syaikh Yusuf menetap di Banten.

Kajian serupa dilakukan oleh George M. Call Theal LLD yang berujudl "History of South Africa under the Administration of the Dutch East Indian Company (1652-1795)”. George M. Call mendeskripsikan kiprah Syaikh Yusuf dalam membela Kerajaan Banten menentang kompeni Belanda yang dianggap menindas. Syaikh Yusuf merupakan seorang tokoh agama yang memiliki pengaruh besar. Baik kajian George M. Call maupun Matthes, keduanya merupakan karya sejarah yang termasuk langka dan sulit ditemukan di Indonesia. Oleh karena itu, penulis merujuk pada ulasan Prof. Dr. Tudjimah.

Selain itu, ada beberapa ulasan singkat tentang Syaikh Yusuf yang pernah dilakukan oleh Ligtvet (1880), Hendrik Carel Vos Leibbrandt (1896), G.W.J. Drewes (1926), A.A. Cense (1950), dan P. Vorhoove (1957).

Berdasarkan identifikasi karya-karya terdahulu, maka kajian tentang etika religius Syaikh Yusuf belum pernah dibahas secara khusus, terlebih jika melihat relevansinya dengan gerakan sosial Islam, yaitu dakwah di tengah-tengah krisis moral.

Teori yang digunakan dalam kajian ini bertolak dari teori etika yang dikemukakan oleh Toshihiko Izutsu dan Soren Kierkegaard, 
tentang keberagamaan yang integral antara moral-spiritual dan amal-sosial. Kedua hal tersebut di dalam karya-karya Syaikh Yusuf dikenal dengan istilah syari'at, tarekat, hakikat, dan makrifat. Izutsu dan Kierkegaard menawarkan suatu konsep universal dalam memahami hakikat agama, yang mana hal tersebut relevan dengan penelitian ini. Untuk memahami pesan-pesan kitab suci, seorang penganut agama harus memiliki perasaan religius yang mendalam untuk memahami Tuhan dan segala kreativitas Tuhan di dunia.

Kierkegaard menyatakan bahwa etika keberagamaan dapat dimulai dari pandangan tentang iman. Menurutnya, seluruh pemahaman akan iman tercermin pada tindakan seseorang. Manusia hanya memiliki dua tujuan dalam hidup, yaitu keabadian atau mencapai kebahagiaan hakiki dari Tuhan: kebahagiaan di dunia dan kebahagiaan di akhirat. ${ }^{20}$ Jiwa manusia berasal dari Tuhan, maka ia telah direncanakan oleh Tuhan untuk hidup secara seimbang sesuai dengan kehendak-Nya.

Sementara itu, Isutzu ${ }^{21}$ menekankan perlunya mengetahui terma-terma etika moral-keagamaan yang terdapat dalam alQur'an dan membandingkannya dengan konsep-konsep etika yang dianut oleh masyarakat Arab pra-Islam. Menurut Izutsu, poros etika Islam adalah sikap manusia terhadap kebaikan Tuhan yang berupa unsur kerendahan hati dan kelembutan. Etika merupakan implementasi dari aspek spiritual Islam. Aspek pertama adalah bahwa Islam sejak awal selalu menekankan tentang Allah yang Maha Murah dan Baik. Di hadapan Tuhan, semua manusia adalah sama dan tidak ada perbedaan derajat dan keturunan (QS. alHujurat: 1041-1042). Kedua, Islam menekankan pentingnya sikap penyerahan diri kepada Allah (QS. ar-Rum: 805). Penyerahan diri

\footnotetext{
${ }^{20}$ Soren Kierkegaard, On Authority and Revelation (New Jersey: Princeton University Press, 1955).

21 Toshihiko Izutsu, God and Man in the Koran: Semantics of the Koranic Weltanschauung (Yogyakarta: Tiara Wacana, 2003), hlm.82.
} 


\section{Pendahuluan}

secara moral dan sukarela merupakan ciri dasar dan syarat utama kesalehan yang Islami. ${ }^{22}$

Kajian ini adalah penelitian kepustakaan dan bersifat kualitatiffilosofis. Sumber data yang digunakan adalah buku, tulisan di jurnal, majalah, bulletin, serta manuskrip/naskah yang memuat pemikiran Syaikh Yusuf. Sumber primernya adalah literatur yang berisi ajaran-ajaran umum dan ajaran-ajaran moral Syaikh Yusuf, sedangkan sumber sekunder adalah literatur yang berkaitan dengan aspek etika atau filsafat moral. Sementara itu, literatur tentang sosiologi, antropologi, sejarah, dakwah, tasawuf, dan literatur Islam lainnya dipergunakan untuk memperkuat analisis dan memahami keterkaitan budaya dan sejarah Syaikh Yusuf.

Penggunaan terjemahan karya-karya Syaikh Yusuf dalam kajian ini lebih sebagai bahan perbandingan, dengan pertimbangan bahwa terjemahan ini merupakan karya yang dapat dipertanggungjawabkan karena dilakukan oleh penulis yang berkompeten di bidang kajian ini.

Kajian pustaka dengan sumber data sekunder tentu saja bermanfaat, sehingga kajian ini bersifat deskriptif-analisis yang mendalam (thick description). ${ }^{23}$ Pendekatan yang berbasis pada ontologi, epistemologi, dan aksiologi dalam mengkaji tokoh beserta karya-karyanya, menjadi sangat penting dan merupakan dimensi pokok kajian kefilsafatan. ${ }^{24}$

Penelitian kualitatif pada umumnya berorientasi eksploratif dan logis. Pendekatannya bersifat induktif, yakni peneliti berupaya

22 Ibid.

${ }^{23}$ Clifford Geertz, The Interpretation of Cultures (New York: Basic Books, 1973), hlm.3-30.

${ }^{24}$ Arief Furchan dan Agus Maimun, Studi Tokoh, Metode Penelitian Mengenai Tokoh (Yogyakarta: Pustaka Pelajar, 2005). 
menyikapi situasi dengan cara rasional. Metode ini menekankan pentingnya pemahaman makna dari perilaku manusia dan konteks sosio-budaya dari suatu interaksi sosial. Metode ini mengembangkan pemahaman empiris antara persepsi personal dan perilakunya.

Tahapan metodis dalam kajian ini adalah mengumpulkan sumber-sumber data yang berhubungan dengan objek kajian. Data yang diperoleh diklasifikasi dan dideskripsikan secara padat dan mendalam. Metode ini dipakai sejak persiapan penelitian, pengumpulan data, dan analisis data.

Tahapan selanjutnya adalah analisis data yang dilakukan sejak tahapan pengumpulan data. Karena objek penelitian yang dikaji berkaitan dengan teks, sejarah, keadaan individu dan sosial masyarakat, maka digunakan beberapa metode dan pendekatan, antara lain: metode historis untuk analisis sejarah, dalam hal ini menganalisis sejarah kelahiran dan pendidikan Syaikh Yusuf. Metode verstehen untuk memahami data berdasarkan karakteristiknya masing-masing, terutama konsep-konsep karya Syaikh Yusuf. Metode interpretasi untuk menunjukkan arti, serta mengungkapkan pemikiran filosofis secara objektif. Metode hermeneutik untuk menangkap makna sesuai dengan konteksnya, khususnya konsep-konsep etika yang terdapat di dalam karyakarya Syaikh Yusuf. Metode analitik bahasa untuk menganalisis konsep pemikiran dalam teks yang sifatnya terminologis. Metode abstraksi untuk melakukan analisis dan menangkap makna sampai pada tingkat hakikat. Terakhir, metode intuitif dan metode heuristik, yaitu untuk menemukan suatu jalan baru yang merupakan suatu pemikiran baru setelah melakukan penyimpulan, kritik atau menemukan suatu metode baru. ${ }^{25}$

\footnotetext{
${ }^{5}$ M.S.Kaelan, Metode Penelitian Kualitatif Bidang Filsafat (Yogyakarta: Paradigma, 2005), hlm.250-254. Joko Suyo, Sumber-Sumber Sejarah: Untuk Penelitian Sejarah Indonesia, Sebuah Pengantar (Surabaya: Perpustakaan Nasional RI, Penyajian Materi Metode Penelitian Sejarah di Jurusan Sejarah Universitas Airlangga, 2006).
} 


\section{Bab II \\ BIOGRAFI SYAIKH YUSUF DAN KARYA-KARYANYA}

Sejarah Syaikh Yusuf tidak terlepas dari sejarah suku BugisMakassar Sulawesi Selatan. Di antara sumber-sumber penelitian tentang kehidupan suku Bugis-Makassar adalah pertama, Lontara atau Lontarak, yakni kitab bacaan yang merupakan rekaman masa lalu Sulawesi Selatan. ${ }^{1}$ Kedua, La Galigo atau I La Galigo, yakni karya sastra Bugis yang disebut-sebut sebagai karya sastra terbesar tahun 1860 oleh bangsawan Bugis dari Tanate bernama Collipujie Arung Pancana Toa Datu Tanate. ${ }^{2}$ Ketiga, arsip-arsip atau naskah yang ditulis oleh sarjana asing atau sebagai arsip-arsip kolonial yang walaupun masih menimbulkan banyak polemik. ${ }^{3}$

Istilah Lontara atau dalam bahasa Makassar Lontarak merujuk pada beberapa pengertian, yaitu: abjad atau huruf, cerita

1 Farid, Andi Zainal Abidin, Lontara Sulawesi Selatan sebagai Sumber Informasi Ilmiah, dalam Andi Rasdiyanah (ed.), (Ujungpandang: IAIN Alauddin, 1982).

2 R.AKern, I Laga Ligo, Catalogus der Boegineesche tot den I Laga Ligo-cyclus behorende handschriften bewaard in het Legatum Warnerianum te Leiden alsmede in andre Europeesche bibliotheken. Leiden, Legatum Warnerianum, 1939., Catalogus van de Boeginese, tot de I La Galigo-cyclus behorende hanschriften van Jajasan Matthes (Matthes-stichting) te Makassar (Indonesiae), Jajasan Matthes, 1954., Een episode uit het I Lagaligo epos, Bijdragen tot de Taal-Land- en Volkenkunde, 1961. (Edisi terjemahan ini adalah hasil terjemahan beberapa bagian dari Karya-karya tersebut di atas. (1993).

3 Ahmad Sewang, Islamisasi Kerajaan Gowa, (Jakarta: Yayasan Obor Indonesia, 2005). 
atau bacaan, sejenis pohon dan lain-lain yang semuanya menjadi lambang identitas suku Bugis, Makassar, termasuk Mandar. ${ }^{4}$ Sedangkan La Galigo merupakan naskah kuno yang menceritakan keadaan atau sejarah Sulawesi Selatan sebelum masuknya Islam. La Galigo sendiri menurut Soebadio. ${ }^{5}$ merupakan peninggalan budaya yang telah diakui mempunyai kepentingan besar sekali guna memahami pikiran yang meskipun berbau mitologi dan berupa masa yang sudah lampau namun konteksnya masih berlaku dan menjadi dasar yang sangat penting untuk memahami sendisendi perwatakan suku di Sulawesi Selatan.

Latar belakang budaya atau masyarakat pada waktu Syaikh Yusuf dilahirkan dan dibesarkan pada abad XVI bercirikan keterbukaan terhadap pengaruh luar yang kian besar. ${ }^{6}$ Sejak awal sejarah, orang-orang Sulawesi Selatan telah mengenal suatu sistem kepercayaaan. ${ }^{7}$ Nenek moyang orang Sulawesi Selatan telah mengenal nama-nama dewa, dan beberapa jenis upacara persembahan telah dilakukan. Inti kepercayaan tersebut adalah konsep-konsep tentang dewa tertinggi yang di sebut To Palaenroe atau sang pencipta Dato Palanro, sang pengatur Aji Patoto, yang dipertuan La Puange, yang mengkaruniakan Rahmat dan menghukum yang bersalah. ${ }^{8}$ Konsep dewa tertinggi ini adalah sisasisa kepercayaan lama orang Bugis pra-Islam yang secara umum disebut Attoriyolong yang secara harfiah berarti tata cara leluhur. Di Kajang disebut Patentung, yang berarti penuntun yang dipimpin oleh seorang yang bergelar Ammatowa yang berarti ayah tertua.

\footnotetext{
4 Abd. Kadir Manyambeang dkk, Lontarak Syekh Yusuf Suatu Analisis Filologi Kultural, (Ujungpandang: Universitas Hasanudin, 1990), hlm. 2.

5 Kern, I Laga Ligo, hlm.5.

6 Mattulada, "Islam di Sulawesi Selatan", dalam Agama dan Perubahan Sosial (1983).

7 Ibid., hlm. 413.

8 Kern, I Laga Ligo, hlm.4.
} 


\section{Biografi Syaikh Yusuf dan Karya-Karyanya}

Kepercaaan tersebut lama-kelamaan kehabisan pengikut dan lambat laun mungkin akan dilupakan. ${ }^{9}$

Pada awal peradabannya, masyarakat Sulawesi Selatan sangat dipengaruhi oleh mitos, ${ }^{10}$ baik yang berwujud tradisi lisan maupun tulis. Misalnya mitos tentang Simpuruh Siang di Luwu, Sinegiri di Bone, Petta Sekkangnili di Soppeng, Puteri Tamalatte di Gowa yang semuanya merupakan To Manurung yang membentuk corak kebudayaan orang Bugis dan Makassar di Sulawesi Selatan. Sedangkan mitos dalam Surek Galigo (sure' galigo) menceritakan tentang awal mula dihuninya negeri Bugis yaitu ketika Batara Guru dari dunia atas Botinglangi bertemu dengan We Nyilitimo dari dunia bawah. ${ }^{11}$

Ada rangkaian peristiwa sejarah yang menandai sejarah masyarakat Sulawesi Selatan pada abad XVI, yaitu: Pertama, ditaklukkannya Malaka oleh Portugis pada tahun $1511 .{ }^{12}$ Selain menyebabkan terjadinya penyebaran agama Kristen, juga menyebarkan benih-benih yang mengganggu jalur perdagangan Nusantara yang selama itu berjalan baik. Berdasarkan beberapa sumber dapat disimpulkan bahwa sebagai akibat jatuhnya Malaka, Sulawesi Selatan menjalin hubungan yang semakin intensif dengan kerajaan-kerajaan lainnya seperti, Aceh, Patani, Johor, Banjarmasin, dan Demak, yang semuanya merupakan pusat-pusat jaringan perdagangan pribumi di Nusantara yang belum menerima Islam sebagai agama resmi. ${ }^{13}$

9 Halilintar Latif, Bissu, Pergulatan dan Peranannya di Masyarakat Bugis (Depok \& Makassar: Desantara dan Latar Nusa, 2004), hlm. 8-9.

${ }^{10}$ Mattulada, "Islam di Sulawesi Selatan", hlm. 413.

${ }^{11}$ Latief, (2004), hlm. 19 dan Kern, I Laga Ligo, hlm 24.

12 Mattulada, "Islam di Sulawesi Selatan", hlm. 387.

${ }^{13}$ Pelras, Christian, The Bugis, (Jakarta: Forum Jakarta-Paris EFEO, 2005), hlm.148150. 
Kedua, perang antara Makassar (Gowa dan Tallo) dengan aliansi besar TellumpoccoE (Bone, Soppeng, dan Wajo) yang bertujuan untuk membendung kekuasaan dan pengaruh kerajaan Gowa yang mulai kuat tahun $1611 .{ }^{14}$ Kedua peristiwa penting tersebut menandai berakhirnya serangkaian peristiwa di abad XVI dan menyebabkan perubahan besar-besaran di Sulawesi Selatan. Penerimaan Islam oleh kerajaan Makassar (Gowa dan Tallo) terjadi pada 1605, 6 tahun sebelum genderang perang ditabuh, diawali dengan dakwah tiga mubalig atau Datuk tallua dari Minangkabau. Orang pertama yang menerima Islam adalah mangkubumi kerajaan Gowa yang juga raja Tallo, bernama I Mallingkang Daeng Awwalul Islam serta raja Gowa XIV sendiri, yang bernama I Mangarangi Daeng Manrabia yang bergelar Sultan Alauddin. Menurut Mattulada (Sewang, 2005: 2) peristiwa masuk Islamnya di kerajaan Makassar merupakan tonggak sejarah Islam di Sulawesi Selatan yang ditandai adanya dekrit Sultan Alauddin tahun 1607 untuk menjadikan Islam sebagai agama kerajaan dan agama masyarakat termasuk kerajaan tetangga, sehingga hal ini menimbulkan gejolak penolakan.

Penguasa Gowa dan Tallo merasa bahwa setelah masuk Islam, peluang menjadi pemimpin seluruh wilayah Sulawesi Selatan yang memang merupakan impian utama, kian terbuka lebar. Begitu kerajaan kembar tersebut menjadikan Islam sebagai agama resmi kerajaan, kemudian mengajak seluruh penguasa di Sulawesi Selatan untuk mengikuti jejaknya. Penolakan terhadap ajakan ini menyebabkan terjadi perang antara kerajaan Gowa dan Tallo yang telah memeluk Islam dengan kerajaan tetangga yang tergabung dalam aliansi TellumpoccoE yaitu kerajaan Bone, Soppeng, dan Wajo. Perang tersebut dalam Lontara Bugis sebagai Musu' Selleng (perang Islam), yang oleh Pelras diterjemahkan sebagai Islamic

${ }^{14}$ Ibid., hlm. 148. 
Wars. ${ }^{15}$. Pada tahun 1608, berhasil menaklukkan Bacukiki', Suppa', Sawitto', dan Mandar, di wilayah Pantai Barat serta Akkoteneng dan Sakholli' di pantai Timur Wajo. Kemudian pada tahun 1609 M, Sidenreng dan Soppeng pun dikuasai menyusul Wajo satu tahun berikutnya. Menyerahnya Bone pada tahun $1611 \mathrm{M}$, membuat seluruh Sulawesi Selatan kecuali Toraja resmi memeluk Islam. ${ }^{16}$

Sekitar tahun 1575, Abdul Makmur, seorang penyiar agama Islam asal Minangkabau yang tampaknya telah menerima pengajaran Islam di Aceh, tiba di Sulawesi Selatan untuk pertama kalinya, dalam upayanya menyebarkan ajaran agama Islam. Dia terhambat oleh berbagai hal seperti kegemaran masyarakat makan dendeng babi, hati rusa mentah yang dicincang dan disajikan dengan bumbu, darah, serta kebiasaaan minum tuak (Pelras, 2006: 158). Abdul Makmur ditemani oleh dua rekannya, yaitu Sulaiman atau Dato ri Patimang dan Abdul Jawad atau Dato ri Tiro; ketiganya adalah orang Minangkabau yang belajar di Aceh dan datang atas perintah Sultan Johor.

Ketika dakwah di Makassar menghadapi tantangan besar, ketiganya meninggalkan Makassar menuju Luwu. Apa yang telah dilakukan merupakan suatu upaya yang ternyata membuahkan hasil. Ketiganya berhasil mengislamkan penguasa Luwu, La Pattiware Daeng Parabung yang secara resmi mengucapkan dua kalimat syahadat, dan mengganti nama menjadi Sultan Muhammad Waliyul Mudaruddin, pada tanggal 5 Februari 1605 M. ${ }^{17}$

Setelah itu, kembali ke Makassar delapan bulan kemudian. Karaeng Matoaya pun masuk Islam dengan mengambil nama Abdullah Awalul Islam dan mendorong kemenakan sekaligus

\footnotetext{
${ }^{15}$ Sewang, Islamisasi Kerajaan Gowa, hlm. 3.

${ }^{16}$ Pelras, The Bugis, hlm.160.

17 Ibid., hlm. 159.
} 
muridnya, raja Gowa I Mang Rangi Daeng Manrabia yang masih muda, untuk memeluk Islam dan mengganti nama menjadi Sultan Alauddin pada sekitar tahun 1607 M. ${ }^{18}$

Pengislaman penguasa Luwu terutama merupakan wujud kepiawaian Dato ri Patimmang yang mampu mewujudkan dogma teologis tauhid atau ajaran tentang keesaan Tuhan, tentang kepercayaan Bugis Saweri Gading dan tarekat yang diajarkannya. ${ }^{19}$ Bahkan sampai saat ini, ajarannya masih dapat ditemukan dalam Lontarak Luwu tentang ajaran tasawuf yang digabungkan dengan mitos Bugis, yaitu dengan menyamakan kisah Adam dan Hawa dengan pasangan yang menurunkan para dewa yang ada dalam siklus naskah La Galigo, serta menggambarkan Saweri Gading sebagai seorang nabi yang meninggalkan bumi dan meramalkan turunnya al-Qur'an. ${ }^{20}$

Setelah berhasil mengislamkan penguasa Luwu, tidak lama kemudian ketiganya mampu mengatasi penentangan penguasa Makassar. Namun demikian, usaha mengajarkan Islam secara mendalam membutuhkan waktu lebih panjang dari perkiraan semula. Meskipun ajaran Islam ortodok terus menerus disebarkan, sisa-sisa kepercayaan leluhur masih dapat ditemukan di pedalaman Bugis. Pada situasi sosial politik seperti inilah Syaikh Yusuf lahir, tumbuh, dan memperoleh pendidikan dasarnya dalam bidang agama dan kemasyarakatan sebelum keluar dari Makassar untuk menuntut ilmu yang lebih tinggi.

\footnotetext{
${ }^{18}$ Ibid., hlm. 159.

${ }^{19}$ Kern, I Laga Ligo, hlm. 107.

${ }^{20}$ Kern, I Laga Ligo, hlm. 100, dan Pelras, The Bugis, hlm.160.
} 


\section{A. Biografi dan Latar belakang Pemikiran Syaikh Yusuf}

\section{Kelahiran}

Yusuf (nama kecil Syaikh Yusuf) lahir di Makassar pada tahun 1626 M. Lontarak Syaikh Yusuf ${ }^{21}$ menceritakan bahwa Yusuf lahir di istana Tallo pada 3 Juli 1626 M/8 Syawal 1036 H, dari puteri Gallarang Moncongloe di bawah pengawasan Raja Gowa. Menurut Da Costa dan Davis, ${ }^{22}$ orang tua Syaikh Yusuf termasuk kaum bangsawan. Ibunya memiliki hubungan darah dengan Raja-raja Gowa, sedangkan ayahnya masih kerabat Sultan Alauddin, salah satu penguasa di Sulawesi Selatan pada saat itu. ${ }^{23}$ Gelar "syaikh" diperoleh dari seorang mursyid tarekat yang membimbingnya, sesuai dengan tradisi ahli tasawuf.

Dalam Tuhfat al-Mursalah, karya Syaikh Yusuf, tertulis nama al-Syaikh Yusuf al-Taj Abu al-Harkani Majalawi. Nama ini menunjukkan seorang waliyullah yang mengetahui asal-usulnya, yaitu keturunan bangsawan Lili negeri Majalawi Makassar. Dalam al-Naba Fi I'rab La ilaaha illallah, tertulis nama al-Syaikh Yusuf bin Abdullah al-Jawi al-Makassari, yang menunjukkan bahwa dia adalah wali sufi dari Tanah Jawi dan Makassar. ${ }^{24}$ Gelar "syaikh" diperoleh menurut tradisi tasawuf setelah ia mendapat izin dari gurunya di Damaskus yang bernama al-Syaikh Abu al-Barokah Ayyub bin Ahmad bin Ayyub al-Khalawaty al-Quraisy, karena Syaikh Yusuf memiliki kemampuan dan penguasaan dalam tarekat. Bagi kalangan sufi, hanya orang-orang yang telah mencapai tingkat tertentu yang berhak memperoleh gelar itu. Nama lengkapnya

\footnotetext{
${ }^{21}$ Manyambeng dkk. (1990), hlm. 16.

${ }^{22}$ Dangor, S., Yusuf Da Costa, Achmad Davis, The Foot Steps in the Companions: SheikhYusuf of Macassar 1626-1699) in Pages from Cape Muslim History (Cape Town: Cape MuslimPress, 1994), hlm, 19.

${ }^{23}$ Mangemba, (1994), hlm.1.

${ }^{24}$ Sultan, Sahib, Allah dan Jalan Mendekatkan Diri Kepada-Nya dalam Konsepsi SysikhYusuf, (Jakarta: Penerbit al Quswa, 1989), hlm. 5.
} 
dalam bahasa Arab adalah Syaikh al-Haj Yusuf Abu al-Mahasin Hadiyatullah al-Taj al-Khalwati al-Maqashshariy. ${ }^{25}$ Nama itu dalam bahasa Indonesia memiliki arti: "Syaikh Haji Yusuf yang mempunyai berbagai macam kebajikan”. Menurut Azumardi Azra, gelar syaikh memiliki makna universal, yang dalam sejarah Nusantara berhubungan dengan ulama yang menguasai tasawuf.

Syaikh Yusuf adalah tokoh tasawuf dari Makassar yang berpengaruh dan berperan dalam pengembangan dakwah Islam, ${ }^{26}$ sehingga namanya disebut juga Syaikh Yusuf Taj al-Khalwaty alMakassary. ${ }^{27}$

Berdasarkan cerita rakyat, pada awal perkembangan Islam di Sulawesi Selatan, orang-orang Makassar, termasuk anak-anak raja meninggalkan negerinya untuk mempelajari tasawuf Islam dan memusatkan perhatiannya pada ilmu kebatinan, kepada seorang guru yang dikenal dengan nama Syaikh Abdul Jabbar Khatib Bungsu di Tiro. Tidak heran bila banyak yang kemudian menjadi sufi dan wali yang memiliki berbagai macam kekeramatan. ${ }^{28} \mathrm{Hal}$ itu, menurut Patunru, seorang sejarawan Makassar, karena keinginan penduduk yang lebih senang pada ajaran-ajaran kebatinan. Alasan inilah yang mempengaruhi dai-dai Islam mengajarkan aliran yang berpaham kebatinan.

Menurut cerita sejarah lokal, ada salah seorang yang diduga murid Datuk ri Tiro yang pergi ke Komara kemudian ke Moncong Loe dan berdiam di sana (diperkirakan sekitar tahun 1625, yaitu sekitar satu tahun sebelum kelahiran Syaikh Yusuf). Murid tersebut adalah seorang tua yang tidak dikenal namanya, kecuali

\footnotetext{
${ }^{25}$ Ibid., hlm.1-3.

${ }^{26}$ Ahmad Purwadaksi, Ratib Samman dan Hikayat Syaikh Muhammad Samman, (Jakarta: UI Press, 2001), hlm. 335.

${ }^{27}$ Cawidu, (1994), hlm. 1.

${ }^{28}$ Sultan, (1989), hlm. 4.
} 


\section{Biografi Syaikh Yusuf dan Karya-Karyanya}

sebagai seorang yang keramat. Oleh sebab itu, orang-orang di sana memberinya gelar penghormatan dan menyebutnya Tuanta Manjalawi. Kata "Manjalawi” diartikan dengan negeri Maniang atau daerah Selatan. Maksudnya adalah daerah-daerah yang ada di sebelah Selatan Gowa dan Tallo. Tetapi, ada juga yang mengatakan bahwa yang dimaksud Manjalawi adalah Moncong Loe itu sendiri, seperti menurut A.A. Cense, bahwa mungkin yang dikatakan Majalawi adalah Moncong Loe. ${ }^{29}$

Pengertian ini menurut Sultan, agaknya tidak tepat karena ayah Syaikh Yusuf bukan berasal dari Moncong Loe asli; ia hanya datang ke Moncong Loe dari Manjalawi. Tampaknya, Manjalawi dalam arti "daerah-daerah Selatan" lebih mendekati kebenaran, terlebih telah ada orang-orang yang dikatakan bangsawan dari daerah-daerah Selatan yang mengaku keturunan Syaikh Yusuf dengan memperlihatkan silsilah keturunan sebagai berikut: $\mathrm{H}$. Raden Muhammad Kamaluddin Dg. Tombong, Qadli Takalar terakhir, H. Andi Muhammad Alwi Arif Dg. Masikki dari Takalar, KH. Abd Qadir Dg. Sutte Pattalassang, Aba Yazid Bostam Dg. Mama’ja Karaeng Galesong XVII, dan H. Madong Dg. Ngampa Soreang. ${ }^{30}$

Menurut pihak bangsawan Gowa, Syaikh Yusuf adalah putra Sultan Alauddin dari istrinya yang bernama Gallarang Moncong Loe. Sultan Alaudin kemudian menceraikan sang istri, dan anaknya diambil alih dan diasuh oleh Sultan Alauddin di istana. Permaisuri sendiri tidak tahu akan hal itu karena perkawinan Sultan Alauddin dengan puteri Gallarang Moncongloe itu dirahasiakan. Setelah diceraikan, janda Sultan Alauddin itu menikah dengan seorang Arab bernama Khidir. Syaikh Yusuf kemudian dididik dan

\footnotetext{
${ }^{29}$ Ibid., hlm.5.

${ }^{30}$ Ibid.
} 
dibesarkan di istana Raja Gowa dengan pengetahuan Islam dan budaya masyarakat. ${ }^{31}$

\section{Pendidikan}

Sejak kecil Syaikh Yusuf hidup di lingkungan yang agamis, dan kecenderungannya pada bidang keruhanian atau spiritualitas Islam. Puang Rama menulis, pada usia 3-4 tahun, Syaikh Yusuf mulai mempelajari huruf al-Qur'an hingga tamat, dan menyempurnakan tajwid dan qira'at dengan fasih, kepada seorang guru yang bernama Daeng Ri Tasammang. Pada usia 8-9 tahun, ia melanjutkan pelajaran ilmu agama Islam kepada seorang ulama besar, mufti Haramayn Makah dan Madinah yang bernama asSyaikh Sayyid Baa Alwi Assegaf bin Abdullah al-Allaamatuttahir Assegaf di Bontoala Makassar. Sang mufti datang ke Sulawesi Selatan pada tahun 1625 M. Dialah orang pertama yang membuka pendidikan agama Islam di Bontoala pada tahun 1635 M.32

Menginjak usia 16-17 tahun, Syaikh Yusuf berkunjung ke Cikowang Takalar untuk belajar ilmu tasawuf kepada ulama besar yang bernama as-Syaikh Syayyid Jalaluddin al-Aidid dari Hadramaut lewat Aceh pada tahun 1645 M. Peran kedua gurunya di Bontoala dan Cikowang inilah yang mendorong Yusuf berangkat ke Makah. Berbekal surat pengantar dari kedua gurunya itu, Syaikh Yusuf menghadap Mufti Makah Imam Syafi'i untuk belajar hingga mencapai puncak intelektual dan spiritual yang tinggi. Sebelum tiba di Makah, Syaikh Yusuf singgah di Banten, lalu ke Aceh.

Selain belajar di Gowa dan Aceh, Syaikh Yusuf juga pernah belajar di Yaman, Hijaz atau Makah dan Madinah, Syam, Damaskus. Setelah tiba di Makah, ia disambut baik oleh mufti dan seorang

31 Ibid., hlm. 99.

32 Puang Rama, S. Djamaluddin Assegaf, "Penyebaran Ajaran Syaikh Yusuf di Sulawesi Selatan", Makalah Seminar Masional diselenggarakan oleh Universitas Hasanuddin, Ujung Pandang, 1994. 


\section{Biografi Syaikh Yusuf dan Karya-Karyanya}

ulama besar yang memegang jabatan sebagai Imam madzhab Syafi'i. Syaikh Yusuf kemudian dinikahkan dengan salah seorang putri Imam Syafi'i. Pernikahannya ini menyebabkan namanya tersebar dan memiliki pengaruh di Jazirah Arab. ${ }^{33}$ Selain itu, dia juga belajar di perguruan tarekat sufi di negeri-negeri Jazirah Arab, sehingga banyak memperoleh ijazah beserta silsilahnya. Setelah kembali ke Tanah Air, Syaikh Yusuf menjadi ulama besar. Syaikh Yusuf mempelajari dan menguasai beberapa tarekat, seperti Qadiriyah, Naqsyabandiyah, Ba'alwiyah, Syattariyah, dan Khalwatiyah. ${ }^{34}$

Lebih detailnya, sejarah pendidikan Syaikh Yusuf dapat dijabarkan sebagai berikut: Setahun setelah Sultan Alauddin wafat pada 15 Juni 1639 M, Syaikh Yusuf bersama Lokmok ri Antang dan Datok ri Paggentungan mengadakan perjalanan ke pedalaman Sulawesi Selatan untuk mencari ilmu. Pengasuhan dan pendidikan Syaikh Yusuf kemudian diambil alih oleh ayahanda Sultan Hasanuddin, yaitu Sultan Muhammad Said, Raja Gowa ke-15 (16391653). ${ }^{35}$

Di Makassar, Syaikh Yusuf sejak kecil dibiasakan hidup menurut norma-norma agama. Kebiasaan yang dianut oleh masyarakat Islam ketika itu, termasuk Gowa dan Tallo misalnya kewajiban belajar al-Qur'an sampai khatam. Setelah itu, dilanjutkan dengan pelajaran bahasa Arab, tauhid, fiqh, dan lain-lain. ${ }^{36}$ Tradisi itu juga dijalani oleh Syaikh Yusuf. Gurunya, I Daeng ri Tasammeng, melihat minat Syaikh Yusuf pada ilmu tasawuf, sehingga ia meminta Syaikh Yusuf untuk mendalami ilmu tasawuf di luar Makassar.

\footnotetext{
33 Ibid., hlm. 2.

${ }^{34}$ Sultan (1989), hlm. 236.

${ }^{35}$ Mangemba (2004), hlm. 99.

${ }^{36}$ Sultan (1989), hlm.12.
} 
Menurut sejarah rakyat setempat, yang mula-mula memperkenalkan tasawuf Islam kepada Syaikh Yusuf adalah dua orang alim di Gowa, yaitu Datuk ri Pagentungan dan Lokmok ri Antang. Kedua orang alim ini kemudian membawa Syaikh Yusuf untuk berkelana ke pedalaman daerah pegunungan hingga ke Latimojong, Bulusaraung, dan Bawakaraeng. Kemudian di atas puncak Gunung Bawakaraeng, ketiganya bertemu dengan seorang waliyullah. ${ }^{37}$

Saat sang guru menganggap pelajaran telah selesai, Syaikh Yusuf diberi pesan untuk melanjutkan perjalanannya menuntut ilmu ke Makah. Kebetulan, pada saat itu Kerajaan Gowa yang sedang berkembang membutuhkan seorang ulama yang mumpuni. Oleh karena itu, beberapa pembesar kerajaan menganjurkan Syaikh Yusuf untuk memperdalam ilmu ke negeri lain. Saat iu, Syaikh Yusuf berusia 18 tahun dan baru saja menikah dengan I Sitti Daeng Nisanga, putri Sultan Alauddin. Sebelum berangkat ke Makah, Syaikh Yusuf terlebih dahulu belajar di pusat-pusat pendidikan Islam, seperti di Banten dan Aceh. ${ }^{38}$

\section{a. Banten}

Syaikh Yusuf tiba di Banten pada masa Sultan Abu al-Mufakhir Mahmud Abdul Qadir yang memerintah tahun 1596-1651. ${ }^{39}$ Semangat merantau dan menuntut ilmu ini sepertinya dipengaruhi oleh hubungan antara Makassar dan Banten-Aceh, sebagai kerajaan-kerajaan Islam, yang sama-sama berjuang menghadapi Portugis dan Belanda. ${ }^{40}$

\footnotetext{
37 Sultan (1989), hlm. 12.

38 Ibid., hlm. 13.

${ }^{39}$ Sebagian pihak menyebut sekitar tahun 1598-1650. Lihat, Solichin Salam, Syaikh Yusuf "Singa dari Gowa" (Ulama Kaliber Internasional) (Jakarta: Yayasan Pembina Generasi Muda Indonesia bekerja sama Gema Salam, 2004).

${ }^{40}$ Nabilah Lubis, Syaikh Yusuf al-Taj al-Makassari, Menyingkap Intisari Segala Rahasia (Bandung: Mizan, 1996).
} 


\section{Biografi Syaikh Yusuf dan Karya-Karyanya}

Setelah menuntut ilmu, Syaikh Yusuf pulang ke Banten dan menjadi ulama yang berpengaruh. Pada tahun 1660 M, Syaikh Yusuf memimpin pasukan perang dan berkali-kali berhasil melumpuhkan musuh, baik melalui strategi kekuatan laut (melalui pelaut-pelaut ulung Banten) maupun kekuatan darat (pasukan gerilya yang berani mati). ${ }^{41}$ Di Banten, Syaikh Yusuf diterima dengan baik oleh Sultan Abdul Qadir. Selain menjadi ulama, Syaikh Yusuf juga menjadi kerabat Kesultanan Banten. Menurut temuan Tudjimah, di Banten banyak murid, termasuk raja-raja Jawa Barat, yang diakibatkan oleh perkawinan dan dakwah, yang mungkin tidak seperti di Makassar. Di Banten, Syaikh Yusuf juga bersahabat dangan Abdul Fattah bin Abu al-Ma'ali bin Abu Mufakhir, putra mahkota yang kelak menjadi raja Banten dengan gelar Sultan Ageng Tirtayasa. Persahabatan ini di kemudian hari memberikan pengaruh yang cukup besar bagi perjalanan hidup Syaikh Yusuf. ${ }^{42}$ Memang tidak disebutkan sampai berapa lama Syaikh Yusuf berada di Banten. Hanya disebutkan bahwa setelah beberapa lama, Syaikh Yusuf melanjutkan pengembaraannya ke Aceh.

\section{b. Aceh}

Syaikh Yusuf tiba di Aceh pada masa pemerintahan Sultan Taj al-Alam Safiatuddin Syah (1641-1675), putra Sultan Iskandar Muda, janda Sultan Iskandar Tsani. Di Aceh Syaikh Yusuf menemui seorang ulama terkemuka yang menjadi mufti kerajaan, yaitu alSyaikh Nuruddin al-Raniri. Dari al-Raniri, Syaikh Yusuf belajar tasawuf dan tarekat dan memperoleh ijazah dalam Tarekat Qadiriyah. ${ }^{43}$ Menurut Lubis, Syaikh Yusuf belajar kepada al-Raniri bukan hanya di bidang agama saja, melainkan juga filsafat kenegaraan. Al-Raniri adalah pengarang kitab terkenal Bustan al-

\footnotetext{
41 Mangemba (1994), hlm.3.

${ }^{42}$ Sultan (1989), hlm.14

43 Ibid., hlm. 14.
} 
Salatin (Taman Raja-raja), yaitu kitab yang mengulas tentang sistem pemerintahan Islam. Menurut sebagian sejarawan, pertemuan Syaikh Yusuf dan al-Raniri terjadi di Gujarat India, bukan di Aceh. Hal ini didasarkan pada fakta bahwa ketika Syaikh Yusuf melanjutkan pengembaraannya ke Makah, al-Raniri sebelumnya telah kembali ke India.

\section{c. Yaman, Hijaz, Syiria, dan Turki}

Dari India, Syaikh Yusuf menuju Timur Tengah, yaitu ke Yaman, Hijaz, Syiria, dan Turki. Di Yaman, Syaikh Yusuf berguru kepada dua orang syaikh yang terkenal pada masa itu, yaitu alSyaikh Abu Abdullah Muhammad Abdul Baqi dan Syaikh Sayyid Ali. Guru yang kedua ini menetap di Zabaid, salah satu wilayah negeri Yaman. Saat itu, Yaman lebih populer dengan sebutan Hadramaut. Dibandingkan Jazirah Arab, Yaman atau Hadramaut lebih dikenal oleh para penuntut ilmu dari Tanah Jawi atau Nusantara. Maka tidaklah mengherankan bila Syaikh Yusuf lebih dahulu memilih Yaman daripada Makah. Dari kedua guru ini, Syaikh Yusuf memperolah ijazah dari Tarekat Naqsyabandiyah dan Ba'alwiyah. Dari Tarekat Naqsyabandiyah, Yusuf diinisiasikan ijazah tarekatnya oleh Syaikh Muhammad Abdul Baqi. Dari Tarekat Ba'alwiyah Syaikh Yusuf mendapatkan ijazah dari Sayyid Ali. ${ }^{44}$

Dari Yaman, Syaikh Yusuf menunaikan ibadah haji ke Makah dan berziarah ke makam Nabi Muhammad di Madinah. Di Madinah, Yusuf bertemu dengan seorang syaikh tarekat Syattariyah, yaitu Syaikh Burhanuddin al-Mulla bin Syaikh Ibrahim ibnu al-Husain bin Syihab al-Din al-Kurdi al-Kurani alMadani. Syaikh Yusuf kemudian menimba ilmu dari Syeikh Ibrahim dan mendapatkan ijazah Tarekat Syattariyah. ${ }^{45}$

\footnotetext{
${ }^{44}$ Sultan (1989), hlm. 15 \& Lubis (1996), hlm. 21-22.

45 Ibid., hlm. 15.
} 


\section{Biografi Syaikh Yusuf dan Karya-Karyanya}

Merasa dahaga intelektual dan pengetahuannya belum terpenuhi, Syaikh Yusuf kemudian menuntut ilmu ke Syiria dan berguru kepada Syaikh Abul Barakat Ayyub bin Ahmad bin Ayyub al-Khalwati al-Quraisyi sampai ia menerima gelar al-Taj dalam Tarekat Khalwatiyah. Menurut riwayat pendidikannya, selain lima aliran tarekat yang disebut di depan, Syaikh Yusuf juga mempelajari beberapa aliran tarekat terkenal, seperti Dasuqiyah, Syadziliyah, Hasytiyah, Rifaiyah, al-Idrusiyyah, Sanusiyah, Maulawiyah, Suhrawardiyah, Makhdumiyah, Kubrawiyah, Madariyah, dan juga Ahmadiyah. ${ }^{46}$

Selain itu, Syaikh Yusuf juga berkesempatan mendatangi Istanbul (Turki). Menurut Hamka, selain belajar ilmu keagamaan, selama di luar negeri Yusuf juga belajar ilmu-ilmu ketatanegaraan. ${ }^{47}$ Setelah kurang lebih 23 tahun mengembara, Syaikh Yusuf kemudian kembali ke tanah air pada tahun $1668 \mathrm{M}$.

\section{d. Makassar, Banten, dan Cape Town (Afrika Selatan)}

Syaikh Yusuf kembali ke tanah air tepat setelah terjadi perjanjian Bongaya antara VOC Belanda dan Makassar, dan perlawanan Raja Gowa tidak lagi memiliki pengaruh yang berarti. Pada saat itu, Arung Palakka, Sultan Bone, memilih berpihak pada VOC Belanda di bawah Spelman, daripada mendukung Sultan Hasanuddin dari Makassar.

Keadaan tersebut di atas menyebabkan masyarakat kembali pada kebiasaan lamanya, yaitu menyabung ayam, minum tuak, dan berjudi. Syaikh Yusuf berusaha untuk memperbaiki keadaan tersebut dengan menemui Raja Gowa saat itu, yaitu Sultan Amir Hamzah (1669-1674), yang masih memiliki hubungan darah dengannya, untuk memberantas kemaksiatan. Namun, raja tidak

\footnotetext{
46 lbid., hlm. 16.

47 Ibid., hlm. 16-17.
} 
memenuhi keinginan Syaikh Yusuf. Kecewa atas sikap raja, Syaikh Yusuf memutuskan untuk meninggalkan Makassar menuju Banten, dan berharap dapat mengembangkan ajaran Islam di bawah pemerintahan Sultan Ageng Tirtayasa, sahabatnya, tahun $1971 .^{48}$ Sebelum meninggalkan Makassar, Syaikh Yusuf telah menyiapkan beberapa kader, termasuk Abdul Qadir Karaeng Majenneng dan Abdul Bashir Dharir, agar tetap melanjutkan dakwahnya.

Menurut Puang Rama, dalam pengembaraannya hingga akhir hayatnya, Syaikh Yusuf tidak kembali lagi ke Makassar. Orang yang melanjutkan dakwahnya adalah muridnya yang bernama Abdul Fathi Abdul Bashir (dengan gelar Tuan Rappang), yang datang ke Gowa pada tahun 1655 M. Tarekat yang diajarkan oleh Tuan Rappang adalah Tarekat Khalwatiyah Yusuf Attajul Khalwaty.

Di Banten, Syaikh Yusuf diterima dengan senang hari oleh Sultan Ageng Tirtayasa dan dinikahkan dengan putrinya sendiri, yaitu Ratu Aminah.49 Di Banten, Syaikh Yusuf menjadi ulama berpengaruh karena pengetahuannya yang mendalam. Sultan Ageng Tirtayasa mengangkatnya menjadi qadli (hakim) dan guru besar agama Islam serta guru besar tarekat sekaligus panglima perang. Karena pada saat itu Banten sedang berkonflik dengan VOC Belanda, Syaikh Yusuf turut serta berperang melawan Belanda. Sejak 1660, pasukan yang dipimpin oleh Syaikh Yusuf berkali-kali memukul mundur pasukan Belanda. Para pelaut Banten yang terkenal keberaniannya turut membantu perjuangan Syaikh Yusuf menghadapi Belanda. ${ }^{\circ}$

Pertengahan tahun 1683, Belanda mengadakan pengejaran secara teratur untuk menangkap Syaikh Yusuf dan putra Sultan Ageng Tirtayasa yang memihak Syaikh Yusuf, yaitu pangeran

\footnotetext{
${ }^{48}$ Mattulada (1983), hlm. 248.

${ }^{49}$ Mangemba (2004), hlm. 99.

${ }^{50}$ Ibid., hlm. 100.
} 
Purbaya. Pengejaran itu berlangsung secara terus menerus, hingga Syaikh Yusuf ditangkap dan diasingkan ke Tanjung Harapan atau Afrika Selatan hingga wafat. ${ }^{1}$

Syaikh Yusuf diasingkan terpisah dari keluarga dan sahabatsahabatnya, yaitu di tempat yang jauh, sekitar 70 kilometer dari Tanjung Harapan. Di tempat pengasingannya, di perkebunan Zandvliet, Syaikh Yusuf mampu meyakinkan kelompok masyarakat yang tertindas lainnya untuk mempertahankan jati dirinya sebagai muslim dan mengaku berasal dari Indonesia. ${ }^{2}$ Jumlah pekerja paksa yang dipekerjakan di perkebunan Zandvliet memang tidak banyak. Namun, wibawa dan pengaruh Syaikh Yusuf mampu masyarakat Cape Melayu hingga dapat bertahan sebagai kelompok yang mempunyai identitas diri hingga saat ini. 53

Perjuangan Syaikh Yusuf melawan Belanda berlangsung kurang lebih 23 tahun, yaitu sejak ia berusia 34 tahun. Daerahdaerah perjuangannya meliputi Banten, Sri Lanka, Cape Town Afrika Selatan. Oleh karena itu, pembahasan tentang Syaikh Yusuf terkait dengan koneksi Melayu-Indonesia yang sangat luas hingga Afrika Selatan.

\section{Kepribadian Syaikh Yusuf dan Guru-gurunya}

Berbagai literatur menggambarkan pribadi Syaikh Yusuf yang begitu agung. Di Makassar sosoknya dikenal sebagai pribadi yang impresif. Meskipun lahir dari keluarga berada dan di dalam lingkungan istana, syaikh Yusuf senantiasa tampil sebagai orang biasa.

\footnotetext{
${ }^{51}$ lbid., hlm.102-106.

52 Abdul Nasier, Saya Asal Macassar, Ramadhan KH dan Fitria Sari, (ed.) (Jakarta: Yayasan Obor Indonesia, 2005), hlm. 225.

${ }^{5}$ Ibid.
} 
Keinginan syaikh Yusuf untuk belajar patut dijadikan teladan. Meskipun derajat ilmunya sudah tinggi, Syaikh Yusuf tidak berhenti menuntut ilmu. Jika terjadi penyimpangan, Syaikh Yusuf tidak segan-segan untuk menyampaikan pandangan atau kritiknya, meskipun, misalnya, di lingkungan istana, tempat ia dibesarkan. Syaikh Yusuf langsung menemui raja dan berdialog dengan tujuan untuk mengingatkan raja. Jika raja tidak mengikuti pendapatnya, Syaikh Yusuf meminta izin untuk hijrah dengan alasan untuk memperdalam ilmu.

Syaikh Yusuf tidak mengenal lelah menuntut ilmu. Di manapun, Syaikh Yusuf mengajarkan kehidupan yang seimbang antara kebutuhan jasmani dan rohani, dahaga intelektual dan biologis secara halal dan benar. Meskipun memiliki derajat tersendiri dan menjadi sufi andal, Syaikh Yusuf tetap rendah hati. Ia bukan seorang sufi yang ekstrem, melainkan sufi moderat yang menguasai ilmu lahir dan batin, tetap membumi dan merakyat. Ia menjadi mufti kerajaan sekaligus tokoh pejuang melawan penjajajan kolonial.

Ketekunan menulis Syaikh Yusuf dilakukan dalam berbagai kondisi, baik normal maupun saat ditahan atau ketika berada di pengasingan. Dia juga tak segan-segan mengajarkan ilmunya kepada masyarakat. Hal ini menunjukkan bahwa Syaikh Yusuf memiliki pribadi yang progresif, sebab ia memiliki metode mengajar yang humanis dan etis.

Ketokohan dan kepribadian Syaikh Yusuf dapat dikategorikan ke dalam empat hal: seorang sufi atau ulama; seorang intelektual atau teknokrat; seorang patriot; dan seorang mubalig.

Adapun guru-guru Syaikh Yusuf adalah sebagai berikut:

1 Sayyid Syaikh Baa'Alwi Assegaf bin Abdullah Allamatuttahir Assegaf (Bontoala, Makassar). 
2 Sayyid Syaikh Jalaluddin Aidid (Makassar).

3 Sayyid Syaikh Hasan bin Ali bin Umar bin Yahya al-Makki (Makah).

4 Sayyid Syaikh ibnu Abdullah Muhammad Assayati Annakasa bandi al-Yamani (Yaman).

5 Sayyid Maulana Syaikh Ibrahim bin Hasan bin Sihabuddin alQurdi.

6 Sayyid Syaikh Muhammad al-Marzu al-Madani (Madinah)

7 Sayyid Syaikh Muhammad ibnu Wajih Assa'di al-Yamani (Yaman)

8 Sayyid Syaikh Maulana Muhammad Baqi al-Naksabandi (Yaman).

9 Sayyid Syaikh Abul Madani di Baghdad (Iraq).

10 Sayyid Syaikh Ayyub bin ahmad al-Ayyubi al-Khalwati alQuraisyi Assani

11 Sayyid Syaikh Muhammd bin Ahmad bin Fadhillah al-Burhan Annufari

12 Syaikh Nuruddin bin Muhammad al-Hamidi al-Quraisyi alRaniri (Aceh)

13 Sayyid Syaikh Abdullah Muhammad Abdul Baqi al-Yamani (Yaman)

14 Sayyid Ibrahim Hasan bin Sihabuddin

15 Syaikh Abu Ayyubi bin Ahmad

16 Sayyid Syaikh Yusuf Abul Madani

Di dunia tarekat, Syaikh Yusuf memperoleh ijazah dari beberapa guru, yaitu:

1 As-Syaikh Nuruddin bin Muhammad Al-Hamidi Al-Quraisy ArRaniri (Tarekat Qadiriyah). 
2 As-Syayyid Syaikh Abdullah Muhammad Abdul Baqi Al-Yamani (Yaman, Tarekat Naqsyabandiyah).

3 As-Syaikh Ibrahim Hasan bin Sihabuddin (Tarekat Syattariyah).

4 Syaikh Abu Ayyubi bin Ahmad (Tarekat Khalwatiyah).

5 As-Sayyid Syaikh Abdul Madani (Tarekat Syadziliyah), serta guru-gurut tarekat yang lain, seperti Ba'alwiyah, Rifaiyah, Muhamadiyah, Maulawiyah, dan sebagainya.

\section{B. Karya-karya Syaikh Yusuf}

Tinjauan umum terhadap naskah atau karya-karya Syaikh Yusuf dalam buku ini merujuk pada penelitian Tudjimah, selain pada naskah atau manuskrip asli yang terdapat di dalam sumber yang lain.

Karya-karya Syaikh Yusuf umumnya didominasi oleh dimensi tasawuf. ${ }^{54}$ Hal ini tidak lepas dari keterlibatan Syaikh Yusuf sendiri dalam berbagai tarekat. Dalam konteks buku ini, penulisan atau pembicaraan tentang etika Syaikh Yusuf menjadi bagian yang tidak terpisahkan dari ajaran-ajaran tasawufnya. Tasawuf menurut Syaikh Yusuf ${ }^{55}$ bertujuan untuk bertemu dengan Tuhan (Allah), melalui syarat kesucian hati (qalbu).

Adapun naskah atau karya-karya Syaikh Yusuf adalah sebagai berikut:

1. Al-Barakat al-Sailaniyyah Minal Futuhat al-Rabbaniyyah

Naskah ini berisi ajaran-ajaran etika dalam berdzikir kepada Allah, tujuan dan makna zikir, macam-macam zikir, cara-cara berdzikir.

${ }^{54}$ Cawidu (1994), hlm.1.

55 Ibid., hlm.2. 


\section{Bidayatul Mubtadi}

Naskah ini menjelaskan tentang prinsip-prinsip kepercayaan (keimanan) dalam Islam, utamanya tentang keimanan kepada Allah Swt., kitab-kitab-Nya, malaikat-malaikat-Nya, nabi-nabiNya, dan qada' dan qadlar. Naskah ini juga menekankan pentingnya kepercayaan atau keimanan bagi seorang muslim sebelum mendalami ajaran-ajaran Islam.

3. Al-Fawaih al-Yusufiyyah fi Bayan Tahqiq al-Sufiyyah

Naskah ini menjelaskan hakikat sufi, yaitu seseorang yang telah mencapai pengetahuan mendalam tentang Allah, dengan melaksanakan syari'at secara lahir dan batin. Selain itu, naskah ini juga membicarakan tentang syarat-syarat seseorang dapat mencapai derajat kewalian, yaitu dengan membersihkan hati dari segala penyakit hati dan cinta dunia. Untuk itu, hal pertama yang harus dilakukan adalah melakukan zikir terus-menerus sehingga merasakan kehadiran Allah dan meyakini bahwa Allah akan menjadi penolong di dunia dan akhirat. Jelasnya, naskah ini menjelaskan jalan yang harus ditempuh oleh seseorang yang ingin mendalami tasawuf tanpa meninggalkan syari'at, sehingga tidak menyimpang dari inti ajaran Islam. ${ }^{6}$

4. Hasyiah fi Kitab al-Anbah fi I'rabi La ilaaha illallah

Menjelaskan makna kalimat tauhid La ilaaha illa Allah. Menurut orang-orang yang tidak meyakini keesaan Tuhan (kafir), terdapat benda-benda lain yang dapat digunakan untuk mendekatkan diri kepada Tuhan yang paling tinggi. Padahal, hanya Allah-lah yang dapat memberi manfaat dan mudarat. ${ }^{57}$

\footnotetext{
56 Tudjimah,Syaiikh Yusuf Makasar, Riwayat dan Ajarannya (Jakarta: UI Press, 1997), hlm. 34-38, dan Naskah Arab RI.

57 Ibid., hlm. 38-39 dan Naskah Arab, Bundel A, hlm. 110.
} 
5. Kifiyat al-Munji wal itsbat bi al-Hadis al-Qudsi

Menerangkan tentang dzikir dan etika dalam berdzikir, penjelasan tentang manfaat-manfaat dan sebab-sebab pentingnya berdzikir kepada Allah.

6. Matalib Salikin

Membicarakan tiga hal penting, yaitu tauhid, makrifat, dan ibadah. Untuk memudahkan para pembaca dan muridnya, Syaikh Yusuf memberikan perumpamaan tentang ketiga hal tersebut sebagai sebuah pohon. Ketiganya merupakan satu kesatuan yang integratif dalam menuju Tuhan. Syaikh Yusuf menganalogikan tauhid sama dengan pohon, makrifat seperti dahan dan daunnya, serta ibadah seperti buahnya. Bagi siapa saja yang ingin memahami hakikat ketuhanan dan menjadi muslim yang sempurna, ketiga hal tersebut harus dipahami dengan baik dan benar. Seseorang dapat menuju Tuhan dengan melaksanakan seluruh perintah dan menjauhi larangan-Nya berlandaskan ilmu tauhid. Dalam kitab Matalib Salikin, Syaikh Yusuf menekankan arti pentingnya memahami tauhid agar tidak jatuh dalam kemusyrikan. ${ }^{5}$

7. Al Nafhah al Saylaniyah

Menurut Tudjimah, naskah ini merupakan ringkasan dari tulisan-tulisan Syaikh Yusuf yang membahas tentang kondisi seseorang saat menuju Allah, seperti fana fillah atau baqa billah, yaitu tentang keadaan leburnya jiwa seorang salik dalam prosesnya mencapai makrifat kepada Tuhan.59 (Tudjimah, 1990: 72; Yusuf, naskah Arab, Perpustakaan Nasional RI).

58 Ibid., hlm. 49-72 dan naskah Arab, bundel A, hlm. 101.

59 Tudjimah (1990), hlm. 72-76 dan Naskah arab. 
8. Qurratul Ain

Penjelasan tentang dzikir dan tafakur. Mengajarkan tentang bagaimana seorang muslim dalam usahanya mendekatkan diri kepada Allah harus melakukan dzikir dan tafakur.

9. Sirrul Asrar

Menjelaskan tentang hakikat makrifat kepada Allah. Yaitu, hakikat mengenal Allah, mulai dari mengenal sifat-sifat dan kebesaran-Nya. Selain itu, juga menjelaskan rahasia pentingnya berdzikir kepada Allah, baik melalui lisan maupun gerak dan hati. ${ }^{60}$

10. Surah

Menjelaskan tentang tiga hal penting: eksistensi Allah, alam, dan manusia, masing-masing dengan kedudukannya. Syaikh Yusuf menekankan bahwa Allah itu berdiri sendiri, sedangkan ruh berdiri dengan Allah. Badan berdiri dengan ruh, lahir berdiri dengan batin, sebagaimana alam berdiri dengan Allah dan bukan karena tempat dan waktu. Allah sebagai poros sentral seluruh jagad raya adalah pencipta segala sesuatu (Tudjimah, 1990: 82; Yusuf, naskah Arab, bundel A. 101).

11. Taj al-Asrar fi Tahqiq Masyarib al-Arifin

Membahas tentang makrifat, yaitu tentang hubungan antara hamba dan Tuhan serta perkataan-perkataan hamba yang telah mencapai makrifat dalam berhubungan dengan Tuhan Allah. ${ }^{61}$

12. Zubdat al-Asrar fi Tahqiq ba'dha Masyarib al-Akhyar

Tentang etika suluk yang selayaknya dilakukan oleh para salik (hamba yang menuju Tuhan). Yaitu, bagaimana etika seorang

60 Ibid, hlm. 76-81.

${ }^{61}$ Tudjimah (1990), hlm. 83 \& naskah Arab, bundle A, hlm. 101. 
salik dalam beribadah, berdzikir, dan berpikir tentang Tuhan dan tujuan hidupnya di dunia dan akhirat. ${ }^{62}$

13. Fathu Kayfiyyat al Dzikr

Menekankan pentingnya dzikir La ilaaha illa Allah dan maknanya. Selain itu, Syaikh Yusuf juga membahas etika yang selayaknya dilakukan oleh seorang salik ketika berdzikir melafalkan kalimat syahadat, baik etika lahiriah maupun batiniah. ${ }^{63}$

14. Daf'ul Bala

Adalah risalah tasawuf yang membahas tentang sifat-sifat Allah, sifat-sifat dan hakikat waliyullah, serta etika dalam berzikir.

15. Hadzihi fawaid azhimat al-dzikr La ilaaha illalah

Membahas tentang faedah-faedah mengucapkan dzikir $L a$ ilaaha illa Allah, dzikir hu, hu, hu, serta dzikir Allah, Allah.

16. Muqaddimah al-Fawaid allati ma labudda minal aqaid

Risalah ini membicarakan tentang hakikat iman dan syaratsyarat seseorang dapat menjadi waliyullah.

17. Tahsilul Inayat wa al-Hidayat

Risalah ini berisi pelajaran tentang hubungan para waliyullah dengan sifat-sifat Allah serta juga pelajaran tentang dzikir dalam upaya mendekatkan diri kepada Allah. ${ }^{64}$

18. Ghayatul ikhtisar wa Nihayat al-intizar

Tulisan ini berisi tentang pengertian dan hukum-hukum ala'yan al-thabitah, (segala sesuatu yang tetap), ibaratnya, dan maknanya. ${ }^{65}$

62 Ibid.

63 Ibid.

${ }^{64}$ Tudjimah (1990), hlm. 104-107 dan Naskah Arab, Bundel A, hlm. 101.

${ }^{65}$ Ibid., hlm. 107-108. 


\section{Biografi Syaikh Yusuf dan Karya-Karyanya}

19. Tuhfatul Amr fi Fadlilat al-dzikr

Risalah ini berisi ajaran tentang sifat-sifat Allah serta kemuliaan zikir La ilaaha illa Allah. ${ }^{66}$

\section{Tuhfat al-Abhar li Ahlil Asrar}

Risalah ini berisi ajaran tentang tauhid, akhlak (etika), kiblat menurut pemahaman kaum sufi dan juga para waliyullah. ${ }^{67}$

21. Al-Washiyyat al-Munjiyyat an-mudahar al-Hijaib

Risalah ini berisi ajaran tentang wasiat yang menerangkan kesempurnaan sifat-sifat Allah, yang suci dari segala kelemahan dan kekurangan. Selain itu, juga berisi wasiat-wasiat tentang pentingnya memperbanyak dzikir kepada Allah. ${ }^{68}$

Saat itu Syaikh Yusuf hanya menulis risalah-risalah pendek. Hal ini karena beberapa hal, pertama, situasi politik yang membuat Syaikh Yusuf disibukkan dengan perjuangan dan pembinaan umat. Hal serupa juga terjadi pada seorang ulama Betawi yang terkenal, yaitu Kiai Syafi'i Hadzami. ${ }^{69}$

Kedua, aspek pengulangan sebagai metode yang mungkin dimaksudkan agar tetap melekat sehingga pesan-pesan dalam pengajaran tidak mudah terlupakan. Pengulangan juga merupakan suatu tradisi dalam sistem hafalan. Keilmuan seseorang dalam tradisi Islam juga dinilai dari kekuatan hafalan serta banyaknya ilmu pengetahuan yang dihafal. Itulah sebabnya mengapa dalam karya-karya Syaikh Yusuf seringkali ditemukan pengulanganpengulangan. Ketiga, kebiasaan atau ciri ulama sufi yang memiliki

\footnotetext{
${ }^{66}$ Ibid., hlm.110-111 dan Naskah Arab.

${ }^{67}$ Tudjimah (1990), hlm. 112-114 dan Naskah Arab, Bundel A, hlm. 101.

68 Ibid., hlm. 114-118.

${ }^{69}$ Retno Kristy, (ed.), Plato, Pemikir Etika dan Metafisika (Jakarta: PT. Gramedia, 2007), hlm. 38.
} 
kedalaman ilmu pengetahuan seringkali tidak mendokumentasikan karyanya secara tertulis; hanya dilihat pada saat menjawab pertanyaan-pertanyaan yang ditujukan kepadanya.

\section{Tokoh-Tokoh yang Berpengaruh terhadap Karya Syaikh Yusuf}

Tokoh-tokoh yang berpengaruh dalam karya-karya Syaikh Yusuf adalah Ibrahim bin Adham, Imam al-Ghazali, Ibnu 'Ataillah al-Iskandari, Abdul Qadir Jailani, Abdul Karim al-Jilli, dan Rabiah al-Adawiyah.

Ibrahim bin Adham. Meskipun tidak ditemukan karya lengkapnya, petuah dan pandangan-pandangannya sering disebut dalam karya Syaikh Yusuf sebagai sufi awal yang memberikan landasan filsafat etis pada perkembangan tasawuf Islam selanjutnya.

Nama lengkapnya adalah Ibrahim bin Adham bin Sulaiman Ibnu Mansur al-Balkhi, keturunan bangsawan yang hidup berkecukupan. Kesadaran spiritualnya muncul ketika sedang berkelana dan memasuki dunia sufisme. Kemudian ia pergi ke Makah, bergabung dengan tokoh sufi Sufyan at-Tsauri. Lalu, berpetualang ke Syam dan memilih bekerja serabutan demi mencari rezeki yang halal, sebagai penjaga kebun dan tukang petik panen. Selain dikenal sebagai seorang tokoh tasawuf, ia juga merupakan seorang ahli hadits. ${ }^{70}$

Imam al-Ghazali, lahir di Tus Iran, adalah tokoh yang sering disebut dalam karya-karya Syaikh Yusuf. Ia seorang ulama yang terkenal menekankan harmonisasi tasawuf dan syari'at ${ }^{71}$ serta

\footnotetext{
${ }^{70}$ Maulana Abdurrahman Jami, Nafahat al Uns min Hadharat al Quds, (terj.) (Beranda, 2007), hlm. 30-32.

${ }^{71}$ Imam, Al-Gazali, Bidayatul Hidayah (terj.) (Jakarta: Khatulistiwa Press, 2007).
} 


\section{Biografi Syaikh Yusuf dan Karya-Karyanya}

membela kaum sufi dari tuduhan yang mengatakan kaum sufi tidak peduli pada syari'at (fiqh). ${ }^{72}$

Dalam dunia sufisme, menurut al-Ghazali, setelah mengenal dirinya dengan benar, maka manusia dapat mengenal Tuhannya. Al-Ghazali menguatkan pendapatnya dengan mengutip hadits Nabi yang berbunyi: "barangsiapa yang mengenal dirinya, ia akan mengenal Tuhannya”.73 Oleh karena itu, orang suci sejati (sufi) akan mengetahui bahwa orang yang tidak bisa menguasai nafsunya, tidak pantas disebut manusia. ${ }^{74} \mathrm{Al}-$ Ghazali juga membahas tentang pentingnya mengenal hakikat dunia setelah mengenal diri dan Tuhan. ${ }^{75}$

Al-Ghazali juga menekankan pentingnya mengenal akhirat. ${ }^{76}$ Keselamatan hanya bagi orang-orang yang mengikuti ajaran Allah, Tuhan yang Maha Esa.77 Ia juga menekankan pentingnya muhasabah dan zikir. ${ }^{78}$ Seorang yang bijak pasti akan melakukan muhasabah setiap pagi setelah shalat subuh ${ }^{79}$ dan berkata kepada jiwanya: "Wahai jiwaku, tujuan hidupmu hanya satu" ${ }^{80}$

Mengenai zikir, tokoh sufi yang sering disebut oleh Syaikh Yusuf adalah Ibnu 'Ataillah al-Iskandari. Menurut Ibnu 'Ataillah, zikir merupakan perintah Allah yang utama. ${ }^{81}$ Dalilnya adalah hadits Nabi (HR. Abu Darda), yang berbunyi:

\footnotetext{
72 Ibid., hlm. 11-29.

${ }^{73}$ Ibid., hlm. 30.

${ }^{74}$ Ibid., hlm. 49.

75 lbid., hlm. 50.

${ }^{76}$ Ibid., hlm. 61-68.

77 Ibid., hlm. 62-82.

78 Ibid., hlm 99.

${ }^{79}$ Ibid., hlm. 100-102.

${ }^{80}$ Ibid., hlm. 103-110.

81 Ibnu Athaillah al-Iskandari, Miftahul Falah wa Misbahul Arwah (terj.) (Jakarta: Serambi Ilmu Semesta, 2006), hlm. 133-192.
} 
"Maukah kuberi sesuatu kepada kalian amal terbaik yang paling mengangkat derajat yang paling bersih di sisi Tuhan kalian? Lebih utama bagi kalian daripada berderma emas dan perak, serta lebih baik daripada memenggal leher mereka yang kafir dan mereka memenggal leher kalian?". Para sahabat menjawab, "Tentu kami mau ya Rasulullah". Beliau bersabda: "Dzikir, mengingat Allah. Makna dzikir Allah terhadap hambanya adalah bahwa barangsiapa yang mengingat-NYa dengan tauhid, niscaya Allah akan mengingatnya dengan surga dan tambahan karunia".

Syaikh Abdul Qadir Jailani, seorang sufi yang juga disebut dalam karya Syaikh Yusuf. Mengenai etika kepada Allah, Syaikh Abdul Qadir menyatakan:

"Tunduk dan rendah hatilah kepada Allah, sampaikanlah segala keperluanmu kepada-Nya. Jangan menganggap amal baik telah kau lakukan. Berpikirlah bahwa amal baikmu dapat terwujud karena karunia Allah. Anggap dirimu tidak berdaya untuk berbuat amal baik apapun. ${ }^{82}$

Abdul Karim al-Jilli. Nama lengkapnya adalah Abdul Karim Qutbuddin ibnu Ibrahim al-Jiili. Dilahirkan dari keluarga sufi agung, Syaikh Abdul Qadir Jailani. Al-Jilli lahir tahun 767 H (1366 M) di Jailan dan wafat tahun 832 H (1430 M). Al-Jilli dinilai sangat berpengaruh dalam tulisan Syaikh Yusuf, dengan konsepnya alInsan al-Kamil atau manusia sempurna. Beberapa kali dalam karyanya Syaikh Yusuf membahas tentang konsep ini, dan menyebut-nyebut al-Jilli sebagai seorang yang memformulasikan konsep tasawuf falsafi.

Pemikiran al-Jilli yang perlu dikemukakan adalah konsep insan kamil tentang duplikasi seseorang dengan yang lainnya. Kesempurnaan seseorang tidak terkurangi sedikit pun dalam hal arad-nya (aksiden). Misalnya, kaki dan tangannya terputus karena satu dan lain hal, atau terlahir dalam keadaaan buta dalam rahim ibunya (cacat bawaan). Jika tidak ada kendala aksiden, manusia

${ }^{82}$ Jailani (2006), hlm. 15. 


\section{Biografi Syaikh Yusuf dan Karya-Karyanya}

satu sama lain adalah cermin dan duplikat bagi insan kamil lainnya, laksana dua cermin yang saling berhadapan, bisa melihat duplikat dirinya sendiri. Namun, di antara manusia sempurna itu ada yang lebih menonjol dalam kedigdayaannya, ada pula karena perbuatannya, yaitu manusia terkasih dan wakil Tuhan (para nabi dan wali). Nabi Muhammad Saw. adalah hakikat insan kamil. Tidak ada satu pun makhluk di dunia ini yang mengungguli Muhammad dalam kesempurnaan dan keutamaan. ${ }^{83}$

Rabiah al-Adawiyah adalah seorang sufi perempuan, yang suci dan agung. Dia sangat dimuliakan oleh para sufi pada zamannya karena pengetahuan dan ibadahnya. ${ }^{84}$

Menurut Rabiah, pemurnian jiwa perlu dengan membersihkan keinginan-keinginan pikiran dan kegemaran pribadi yang buruk. Tujuan utama berdoa bukanlah semata-mata sebagai sarana penghubung, melainkan sebagai kesempatan untuk berkomunikasi dengan Tuhan yang memungkinkan sang hamba untuk mengetahui kehendak yang diberikan oleh-Nya. ${ }^{85}$

Rabiah adalah sufi pertama dalam tasawuf yang mengajarkan konsep cinta, yang membimbing seorang sufi di jalan mistis dan hanya melalui jalan cinta, seseorang akan sampai pada tingkat kesempurnaannya. ${ }^{86}$

\footnotetext{
${ }^{83}$ Abdul Karim Al- Jilli, Al Insan al Kamil Fi Ma'rifatil Awail wal Awakhir (terj.) (Jakarta: Serambi Ilmu, 2006), hlm. 316.

${ }^{84}$ Margareth Smith, Studies in Early Mysticism in the Near and Middle East (terj.) (Jakarta: Gaya Media Pratama, 2007), hlm. 177.

${ }^{85}$ Ibid., hlm. 281-281.

${ }^{86}$ Ibid., hlm. 282.
} 



\section{Bab III \\ BASIS PEMIKIRAN ETIKA RELIGIUS SYAIKH YUSUF}

Pada prinsipnya, karya-karya Syaikh Yusuf menekankan pada pentingnya penguasaan syar'iat, baik secara lahir maupun batin. Hampir semua karyanya yang berhasila ditemukan berkaitan dengan masalah tasawuf dan tarekat, selain masalah keislaman lainnya. Hamid mengidentifikasi karya Syaikh Yusuf berjumlah 29 karya, ${ }^{1}$ sedangkan Tudjimah mengidentifikasi 23 karya. ${ }^{2}$

Penulis mendapatkan karya-karya Syaikh Yusuf dalam bahasa Arab, yang pembahasannya berkisar pada masalah tasawuf. Dimensi mistiknya sangat dominan, bahkan dapat dikatakan merupakan master key dari seluruh karyanya. Menurut Cawidu, ${ }^{3}$ keterlibatan Syaikh Yusuf dalam tarekat dan tasawuf sangat dalam dan total. Hal ini terlihat dari kisah pengembaraan ilmiahnya ke berbagai negara, berguru kepada syaikh-syaikh tarekat dan sufisufi besar, sehingga hampir semua tarekat besar di dunia Islam telah dijalani.

Abu Hamid, Syaikh Yusuf, Seorang Ulama, Sufi dan Pejuang (Jakarta: Yayasan Obor Indonesia, 2005).

2 Tudjimah, Syaikh Yusuf Makasar, Riwayat dan Ajarannya (Jakarta: UI Press, 1997).

3 Cawidu, Harifuddin, "Peringatan 300 Tahun Mendaratnya Syaikh Yusuf AlKhlwaty Al-Makassary di Afrika Selatan", Makalah Seminar Nasional), Ujung pandang: Universitas Hasanuddin, 1994, hlm.1-14. 
Perlu dikemukakan di sini bahwa trend mempelajari tasawuf pada zaman Syaikh Yusuf (abad XVIII M) memang sangat mengglobal di dunia Islam. Seperti kita ketahui, setelah pusat kekuasaan politik dan peradaban Islam hancur, baik di Timur (Baghdad-Abbasiyah) maupun di Barat (Cordova, Granada, Sevilla-Andalusia) pada abad XIII dan XIV M, umat Islam mengalami kemunduran dalam semua bidang kehidupan. Sebaliknya, umat Islam memasuki era kejayaan spiritualisme dengan ciri utamanya adalah kehidupan mistik atau tasawuf. ${ }^{4}$ Kemudian muncul tiga kerajaan besar Islam pasca Abbasiyah, yaitu Shafawiyah di Persia, Mughal di India, dan yang paling besar Utsmaniyah di Turki. Namun, kerajaan-kerajaan itu tidak lagi mengembangkan peradaban keilmuan dan intelektualisme seperti era Baghdad atau Cordova, kecuali Shafawiyah di Persia yang beraliran Syiah. Shafawiyah tetap memelihara tradisi keilmuan, namun gaungnya tidak keluar karena dominasi kaum Sunni yang lebih menonjolkan spiritualisme ketimbang intelektualisme. Menurut Cawidu, ${ }^{5}$ Islam yang masuk ke Indonesia adalah Islam mistik versi Ghazalian dan sedikit bercorak Arabian (Ibn Arabi), sehingga tarekat dan tasawuf sangat subur di Nusantara. Di sisi lain, Syaikh Yusuf lahir dan besar ketika tarekat dan tasawuf tumbuh subur di Indonesia. Oleh karena itu, pembahasan tentang etika dari ajaran-ajaran Syaikh Yusuf merupakan bagian yang tidak terpisahkan dari ajaran-ajaran tasawufnya. ${ }^{6}$

Konsep etika religius menitikberatkan pada perbuatan dan pengamalan dari ajaran agama. Etika religius Syaikh Yusuf dipandang sangat relevan dengan kondisi di Indonesia pada saat

4 Harun Nasution, Falsafah dan Mistisisme dalam Islam (Jakarta: Bulan Bintang, 1973), hlm.1043.

5 Ibid., hlm.2-4.

6 Fadiman, James F. and Robert Franger (eds.), (terj.) (Yogyakarta: Pustaka al-Furqan, 2007 ). 


\section{Basis Pemikiran Etika Religius Syaikh Yusuf}

ini, karena pemikirannya mengandung kritik sosial dengan menawarkan hakikat Islam secara lahir dan batin atau mengerti syari'at dan tasawuf, lebih-lebih jika dikaitkan dengan perkembangan dakwah Islam di Indonesia saat ini. Di tengah kegandrungan juru dakwah yang mengadopsi ulama Timur Tengah atau Arab, eksistensi tokoh lokal justru jauh lebih kontekstual dengan karakteristik masyarakat Indonesia.

Untuk memahami landasan etika religius Syaikh Yusuf, kita perlu mengetahui terlebih dahulu beberapa konsep kunci dalam karya-karyanya. Konsep-konsep tersebut merupakan empat tingkatan dalam praktik sufisme, yaitu syari'at, tarekat, hakikat, dan makrifat.

\section{A. Syari'at}

Syari'at adalah jalan terang dan jalan baik yang dapat diikuti oleh setiap orang. ${ }^{7}$ Syaikh Yusuf memberikan makna filosofis dalam karyanya, al-Nafhat al-Sailaniyya, bahwa syari'at adalah katakata atau pemahaman Islam (teaching of Islam.) ${ }^{8}$ Makna yang paling mendasar, syari'at adalah etika dan moralitas yang bisa ditemukan pada semua agama. Syari'at menyediakan tuntutan untuk hidup dengan sebaik-baiknya di dunia ini. Tanpa mengikuti syari'at, ibarat membangun rumah tanpa fondasi. Karena kehidupan dibangun di atas prinsip-prinsip moral dan etika, maka mistisisme tidak dapat berkembang.

Syari'at adalah tahapan di mana gagasan tentang Tuhan berkesan pada manusia sebagai wibawa yang merujuk pada rasa

\footnotetext{
7 Syaikh Yusuf, "Al Barakat al Sailaniyyah minal Futuhat al Rabbaniyyah", dalam Tudjimah (ed.), Syaikh Yusuf, Riwayat, Hidup, Karya dan Sejarahnya (Jakarta: UI Press, 1997).

8 Martin Lings, What is Sufism (Yogyakarta: Futuh Printika, 2004). Lihat juga, Martin Lings, Muhammad: His Life Based on the Earliest Source (Jakarta: PT. Serambi Ilmu Semesta, 2007), hlm.123.
} 
tunduk kepada Tuhan. Ini adalah laku kesadaran, bukan wujud ketakutan sebagaimana yang sering diperkirakan orang. Misalnya, seseorang berdoa, menyembah, dan memikirkan Tuhan, serta memilih untuk membangun hubungan dengan-Nya, sehingga di saat tidak berdaya maka ia akan kembali kepada Tuhan.

Syari'at adalah tahapan ketika seseorang berpikir tentang sesuatu yang menyenangkan atau mengecewakan. Diawali dengan mempelajari agama dari orang tuanya, bahwa perbuatan baik akan membahagiakan dan kesombongan akan mengecewakan. Ganjaran baik dan hukuman dapat dilihat dari keseharian seseorang, jadi tidak perlu menunggu ketika ia berada di surga atau neraka, karena setiap hari adalah surga atau neraka apabila menyadari bahwa segala sesuatu memiliki reaksi, ada timbal-balik dari perbuatan yang dilakukan. Yang dimaksud dengan tahapan syari'at adalah bahwa kaum sufi tetap melaksanakan kewajiban-kewajiban hukum (fiqh). Jadi memahami syari'at dalam konteks ini adalah kaum sufi tetap terikat pada hukum-hukum yang disepakati oleh para fuqaha meskipun mereka telah sampai pada derajat makrifat.

Tasawuf didasarkan pada keyakinan, bukan pada pendapat. Tasawuf tidak dapat diganggu gugat karena mistisisme sering disebut sebagai gudang kebenaran dalam pengertian yang sesungguhnya, terutama yang menyangkut Yang Maha Mutlak, Yang Maha Agung dan Abadi. ${ }^{9}$ Ilmu tasawuf memiliki hak sekaligus kewajiban untuk ditawar, bukan hanya secara objektif dengan menyatakan bahwa segala sesuatu yang pertama adalah pertama, melainkan secara subjektif juga menempatkan yang pertama. Sementara pengetahuan hanya menyelamatkan manusia untuk melakukan transformasi.

9 Syah, Omar Ali, Sufism as Theraphy (terj.) (Yogyakarta: Futuh Printika, 2004), hlm. 225-226. 


\section{Basis Pemikiran Etika Religius Syaikh Yusuf}

Aspek eksklusivitas dari tasawuf ini hanya mengidentifikasi pada orang-orang yang memenuhi kualifikasi untuk menjadi penempuh jalan Tuhan (salik) dalam pengertiannya yang utuh, meskipun secara periodik, aspek eksklusivitas ini merupakan sarana keterbukaan. Sebagian kaum agnostik dan ateis menjadi demikian, karena alasan-alasan yang tidak dapat dinilai salah sama sekali. Ateisme ataupun agnotisisme bisa merupakan pemberontakan seorang ahli mistik sejati yang menentang batasan-batasan eksoterisme. Sebab, dalam diri seseorang tidak mustahil terdapat sifat seperti ini, tetapi tidak berkembang. Sedangkan kualifikasikualifikasi dalam tasawuf lebih memungkinkan dicapai oleh naluri manusia sebagai makhluk yang diberi kesadaran untuk kembali kepada Sang Pencipta.

Dzikir, yang menjadi bagian dari tarekat, berfungsi untuk menjaga hubungan antara manusia dan Tuhan serta meneguhkan tujuan dalam diri. ${ }^{10}$ Dzikir dalam hati merupakan sarana berkomunikasi dengan Tuhan. Dalam konteks ini jiwa esensial akan terhubung dengan pengulangan dzikir dan pengakuan atas kualitas-kualitas dzikir. Artinya, jiwa esensial akan dapat merasakan pengaruh dari hubungan yang dilakukan seseorang dengan dzikir yang ikhlas dan benar.

Berkenaan dengan dzikir yang berlandaskan syari'at, yaitu menjaga tauhid dari unsur-unsur syirik, Syaikh Yusuf menjelaskan tiga macam dzikir dalam karyanya, al-Barakat al-Saylaniyyah, sebagai berikut:

1. Dzikir al nafi wa ithbat, yang berupa La ilaaha illa Allah.

2. Dzikir mujarrad wal jalala, yang beruapa Allah Allah.

3. Dzikir al Ishara wal Anfas, yang beruapa $H u, H u$.

\footnotetext{
${ }^{10}$ Yusuf, dalam Tudjimah, hlm. 22.
} 
Dzikir yang pertama disebut dzikir lisan, yang kedua disebut zikir qalb, dan yang ketiga dzikir sirr. Dzikir pertama disebut makanan lisan, yang kedua disebut makanan hati, dan yang ketiga disebut makanan rahasia. Ada yang mengatakan La ilaaha illa Allah itu hidupnya hati, Allah, Allah itu hidupnya ruh, dan $H u$, $\mathrm{Hu}$ itu hidupnya rahasia. ${ }^{11}$

Pada hakikatnya, dzikir merupakan buah dari keimanan dalam Islam. Dzikir yang pertama adalah keyakinan teguh untuk mengakui hanya Allah sebagai Tuhan yang patut disembah dan tempat bergantung. Zikir ini disebut penetapan, yaitu untuk menekankan pentingnya pengetahuan bahwa hanya Allah yang menjadi Tuhan. Sementara penolakan terhadap tuhan-tuhan kecil menunjukkan pandangan dasar filosofi tauhidbahwa kebenaran adalah hanya dengan mengakui Tuhan Yang Satu.

Dzikir yang kedua penekanannya hanya menyebut nama Tuhan (Allah), karena tahapan dzikir ini lebih tinggi dari dzikir yang pertama, yaitu menghujamkan keyakinan bahwa hanya Tuhan Allah-lah kebenaran yang satu. Menurut Syaikh Yusuf, dzikir ini merupakan pelatihan untuk mendekatkan diri kepada Yang Maha Mutlak dalam konsepsi ontologis tentang Tuhan dan manusia.

Dzikir yang ketiga adalah dzikir yang telah menghujam dalam dada dan hidup di dalam keyakinan seorang muslim tentang ontologisme Tuhan dan hubungannya dengan hamba. Pengucapannya menjadi lebih ringkas karena merujuk hanya kepada Dia, yang dalam bahasa Arab disebut Huwa; tidak lagi menyebut nama. Hal ini karena kedekatan hati, dan kedekatan ini merupakan konsep yang sangat rahasia. Karena itulah, dzikir ini disebut rahasia hati.

Pada akhirnya, tidak ada yang maujud secara hakikat, kecuali Allah. Pelaku dzikir yang pertama disebut ahl al-Bidaya min al

11 Ibid. 
awam, dzikir yang kedua disebut ahl al-khawas, dan dzikir yang ketiga disebut zikir ahl khas al-khawas.

Bagaimana mengingkari nyatanya alam ini, yang bisa dilihat dengan mata telanjang, bahwa alam itu ada tanpa keraguan sama sekali? Dalam istilah ahli ketuhanan, wujud yang benar itu hanya yang berdiri sendiri, sedangkan yang fana itu wujudnya hanya khayal dan tidak sebenarnya. Al-Salik itu harus dzikir. ${ }^{12}$

Syaikh Yusuf membagi tingkatan dan tahapan orang-orang yang melakukan dzikir ke dalam tiga bagian: tingkat dasar, tingkat menengah, dan tingkat tinggi. Merujuk pada al-Qur'an, Syaikh Yusuf menulis: "Ingatlah kepadaku, Aku akan ingat kepadamu. Dzikir yang paling utama adalah dzikir La ilaaha illa Allah, dengan menunjuk pada hadits yang artinya: Ummul mukminin telah berkata, Rasulullah Saw: mengingat Tuhan setiap waktu dari segala keadaan. Wahai murid, mengertikah engkau ucapan Nabi, dan syahadat itu ada dua macam: Al-shayahadat al Mukhtassah dan asy-Syahadah al Mutlaqa. Yang pertama adalah kalimat Asyhadu an La ilaaha illallah wa asyhadu anna muhammada rasulallah, sedangkan yang kedua adalah Asyhadu an La ilaaha illallah wahdahu la syarikalahu wa asyhadu anna muhammadan abduhu wa rasulallah. ${ }^{13}$

Orang yang berdzikir dengan kalimat La ilaaha illa Allah ada empat macam: (1) Mengucapkan dengan lisan dan hati, tetapi tidak percaya, maka disebut munafik; (2) Mengucapkan dengan lisan dan hati, disebut mukmin yang umum; (3) Mengucapkan dengan hati saja disebut orang khusus; (4) Mengucapkan dengan kesungguhan hati dan ia fana dari segala sesuatu selain Allah dan hanya melihat Allah, disebut khas al- khas. ${ }^{14}$

\footnotetext{
12 Ibid., hlm.23.

13 Ibid.

14 Ibid.
} 
Syaikh Yusuf juga mengklasifikasi waktu dzikir ke dalam tiga mukashafa: (1) Mukhasafa hati dari zikir, La ilaaha illa Allah; (2) Mukashafa ruh dari zikir, Allah, Allah; (3) Mukashafa sirr dari zikir, $\mathrm{Hu}, \mathrm{Hu} .^{15}$

Syaikh Yusuf juga menekankan pentingnya keikhlasan dalam melaksanakan dzikir. Terkait dengan ini, beberapa ahli fana berkata:

Siapa yang tidak merasa tidak tahu rahasia Tuhan yang diberikan kepada hamba-Nya di antara orang arif yang sempurna. Dikatakan: Membuka rahasia Tuhan itu kafir, hal itu tidak diketahui kecuali oleh "Man Kana huwa nahnu huwa". Berkata di antara mereka yang besar: "Siapa yang berdiri pada tempat (sembahyangnya), puasanya dan merasakan makanannya dan mengerti perkataaanya, maka ketahuilah ia". ${ }^{16}$

Dalam Bidayat al-Mubtadi, Syaikh Yusuf menerangkan pentingnya pemahaman akan syari'at, yaitu pemahaman tentang hakikat Tuhan dan kewajiban muslim.

Sesungguhnya Tuhan itu "Laisa ka mithlihi syai", Allah itu satu, tidak ada teman dalam zat, sifat, dan af'al-Nya. Tuhan berbeda dari semua yang dikhayalkan dalam pikiran. Semua kepercayaan itu kembali pada surat al-Ikhlas. Adapun tawajjuh kepada Allah itu supaya menghadap dengan sepenuh hati dalam berbagai keadaan kepada Allah, yaitu tidak ada yang lain dalam pikiran kecuali Allah. Selain itu, Tuhan mengajarkan hakikat makrifat sehingga tidak ada hijab antara Tuhan dan hamba-Nya karena mengucapkan La ilaaha illa Allah dengan melupakan semua ciptaan-Nya pada waktu dzikir. ${ }^{17}$

Dalam Tuhfat al-Amr Fi Fadilat Al-dzikir, Syaikh Yusuf menjelaskan tentang keutamaan dzikir:

\footnotetext{
15 Ibid., hlm.23-24.

16 Ibid., hlm.26-27.

17 Ibid., hlm.99-100.
} 


\section{Basis Pemikiran Etika Religius Syaikh Yusuf}

Ketahuilah wahai talib, yang ingin pada kebaikan, yang mencari berkah. Seorang hamba yang salik yang mencari dzikir yang paling mulia, yaitu dzikir La ilaaha illa Allah, karena sabda Nabi Saw: "Yang kuucapkan dan diucapkan oleh nabi-nabi sebelumku yang paling mulia adalah La ilaaha illa Allah.

Sabda Nabi Saw: Jika Allah menginginkan hamba-Nya menjadi baik, Dia memberi ilham untuk berdzikir kepada-Nya. Allah memerintahkan untuk memperbanyak dzikir kepada-Nya dengan firman-Nya: "Ingatlah kepada Tuhan banyak-banyak". ${ }^{18}$

Dzikir bagi Syaikh Yusuf merupakan gerbang utama untuk memahami ontologi dan epistemologi hubungan Tuhan dengan manusia, karena dzikir (La ilaaha illa Allah) merupakan bagian penting dari tauhid.

Menurut Syaikh Yusuf, hakikat kefakiran adalah saat manusia tidak membutuhkan makhluk ciptaan Tuhan lainnya. Siapa pun yang memilih jalan tasawuf, ia harus mengetahui bahwa tasawuf dimulai dari kelembutan jiwa. Jalan tasawuf ditempuh dalam delapan cara. Pertama, sebagaimana kemurahan Nabi Ibrahim; kedua, ridla Nabi Ishaq; ketiga, kesabaran Nabi Ayub; keempat, isyarat Nabi Zakaria; kelima, kesepian Nabi Yahya; keenam, busana bulu domba Nabi Musa; ketujuh, langlang buana Nabi Isa, dan kedelepan, kefakiran Nabi Muhammad Saw. ${ }^{19}$

Adapun adab/etika dalam berdzikir adalah sang salik terlebih dahulu bertaubat dan memperbaiki jiwa dengan latihan-latihan rohani, menjauhi hal-hal yang duniawi, dan tidak ada rintangan. Selain itu, ia harus memahami ilmu-ilmu agama yang bersifat wajib dan memiliki dzikir yang sesuai dengan keadaannya. ${ }^{21}$ Etika lainnya

\footnotetext{
${ }^{18}$ Abdul Qadir al Jailani, Adab al Suluk wa Tawasul ila Manazil al Muluk (terj) (Jakarta: Pustaka al Furqan, 2006), hlm.252-253.

19 lbid., hlm. 254.

${ }^{20}$ Ibnu Athaillah al-Iskandari, Miftahul Falah wa Misbahul Arwah (terj.) (Jakarta: Serambi Ilmu Semesta, 2006), hlm. 62.

${ }^{21}$ Ibid., hlm.63.
} 
adalah menggunakan pakaian yang halal, suci dan wangi. Kesucian batin dapat terwujud dengan memakan makanan yang halal, karena dzikir pada hakikatnya dapat melenyapkan dosa dari sesuatu yang haram. Jika batin telah kosong dari yang haram/syubhat, maka dzikir akan berfungsi menerangi qalbu atau hati. ${ }^{22}$ Etika lainnya adalah niat yang ikhlas atau hatinya sepi dari selain Allah. ${ }^{23}$

Dzikir dengan membaca al-Asma al-Husna diyakini berfungsi sebagai obat bagi penyakit qalbu, sekaligus sarana bagi salik untuk mendekatkan diri kepada Allah. ${ }^{24}$

Jelasnya, etika Syaikh Yusuf menekankan tiga hal: (1) Etika yang berkaitan dengan pencarian kebahagiaan; (2) Etika yang berhubungan dengan rasionalitas dan ilmu; (3) Etika sebagai pengobatan rohani. Sementara itu, etika dalam melaksanakan syari'at untuk mencapai makrifat adalah: (1) Menjalin persahabatan dengan orang-orang fakir melalui sikap tawadlu; (2) Memiliki sikap yang baik; (3) Dermawan; (4) Mampu mengendalikan hawa nafsu, karena makhluk yang paling dekat dengan Allah adalah orang yang memiliki akhlak, dan sebaik-baik perbuatan adalah menjaga hati agar tidak berpaling kepada selain Allah. ${ }^{25}$

\section{B. Tarekat}

Dalam al-Nafhat al-Sailaniyya, Syaikh Yusuf memaknai tarekat sebagai hal atau kondisi diri untuk menghampiri Allah (the way to God). ${ }^{26}$ Tarekat mengacu pada praktik atau laku sufisme. Jalan ini tidak selalu terang seperti halnya jalan raya, dan juga

\footnotetext{
22 Ibid., hlm. 62-68.

${ }^{23}$ Ibid., hlm.77.

24 Jailani, hlm. 254.

${ }^{25}$ Yusuf dalam Tudjimah (1997), hlm. 42.

${ }^{26}$ Fadiman, James F. and Robert Franger (ed.), (terj) (Yogyakarta: Pustaka al-Furqan, 2007), hlm. xxi.
} 
bukan jalan yang bisa dilihat dengan kasat mata. Dalam konteks ini, syari'at hanya mengacu pada aspek lahiriah, sedangkan tarekat pada laku batiniah/sufisme. Pemandu yang dibutuhkan adalah seorang syaikh atau guru sufi yang dapat menunjukkan jalan untuk mencapai Tuhan. Syari'at membuat kehidupan sehari-hari menjadi menarik, sedangkan hakikat dirancang untuk membentuk kehidupan batin menjadi bersih dan murni. Dalam hal ini, syari'at dan hakikat bersifat saling melengkapi. ${ }^{27}$

Sebagai institusi, tarekat muncul pada abad IX. Pada masa itu kaum sufi terkenal zuhud, dan mereka berkumpul dalam suatu ikatan persaudaraan yang tidak terorganisir, tetapi mempunyai pertemuan rutin yang biasa disebut ribat. Kemunculan tarekat merupakan suatu ijtihad untuk mengarahkan konsep menuju Tuhan yang lebih terorganisir. Karena itu, kaum sufi diharuskan memiliki syaikh atau mursyid. Seperti dituturkan oleh Syaikh Yusuf:

... jika kamu seorang salik, maka wajib bagimu untuk mencari syaikh yang saleh dan arif yang dapat menunjukkan jalan menuju Tuhan, meskipun engkau harus meninggalkan keluarga dan negaramu untuk mencarinya. Sesungguhnya orang-orang sesudah Nabi tidak terpelihara dari maksiat dan dosa, sebagaimana sabda Nabi Saw: "Siapa yang terpelihara dari dosa sesudah aku, maka ia bukan umatku, ketahuilah itu. ${ }^{28}$

... dalam bertarekat, kamu harus menyatukan syari'at dan hakikat, karena Nabi bersabda: "Aku diutus membawa syari'at dan hakikat". Nabi-nabi tidak diutus untuk membawa syari'at saja. Sabda Nabi yang lain: "Syari'at itu kata-kataku, tarekat itu hal-ku, dan hakikat itu hatiku. Seperti dikatakan bahwa Syaikh al-Imam abu Yazid al-Bustami mengatakan: "Tiap-tiap syari'at tanpa hakikat itu batil, dan semua hakikat tanpa syari'at itu kurang sempurna". ${ }^{29}$

\footnotetext{
${ }^{27}$ Yusuf dalam Tudjimah, hlm. 41-42 dan Yusuf dalam Naskah Arab bundle A. hlm.101.

${ }^{28}$ Yusuf dalam Tudjimah, hlm. 42.

29 Ibid., hlm. 43.
} 
... siapa berilmu, tetapi tidak bertasawuf, itu fasik. Siapa yang bertasawuf, tetapi tidak berfigh, itu zindik. Siapa yang berfigh dan bertasawuf ia berhakikat. Di antara mereka ada yang berkata: Seorang salik pada lahirnya memegang teguh syari'at dan batinnya terikat pada hakikat. Dikatakan bahwa jalan dan suluk yang terpuji itu ada yang lahir dan ada yang batin. Lahirnya disebut syari'at, batinnya disebut hakikat. ${ }^{30}$

Syaikh Yusuf menekankan pentingnya pengetahuan dasar yang bersumber dari syari'at Islam. Pemahaman yang benar tentang syari'at akan membawa seseorang mencapai hakikat kebenaran. Seseorang akan mengetahui dan memahami ontologi hubungan antara Tuhan dan ciptaan-Nya berdasarkan epistemologi yang benar, yaitu syari'at.

Menurut Syaikh Yusuf, jalan kepada Allah itu banyak, sama banyaknya dengan jiwa makhluk. Jalan yang paling dekat ada tiga, yaitu: (1) Jalan al-akhyar. Memperbanyak sembahyang, puasa, membaca al-Qur'an, hadits, jihad. Salik yang sampai kepada Allah dengan jalan ini sangatlah sedikit. (2) Jalan ashab al-Mujahadat al-shaqa, yaitu mensucikan hati. Salik yang sampai pada jalan ini lebih banyak dari salik di jalan yang pertama. Jalan pertama hanya melihat amal lahir tanpa amal batin, sedangkan jalan yang kedua memperhatikan batin daripada lahir. (3) Jalan ahli dzikir, yaitu mencintai Tuhan lahir-batin. Mereka adalah salik yang sampai pada ahli bidaya dan memperhatikan amal lahir dan batin. ${ }^{31}$

Namun, Syaikh Yusuf menyatakan bahwa bahwa jalan menuju Tuhan terdiri dari sepuluh macam, yaitu: diawali dengan taubat kepada Allah, zuhud di dunia, tawakal kepada Allah, mensyukuri apa yang diberikan Allah, menjauhkan diri dari seluruh aktivitas duniawi, tawajjuh kepada Allah, sabar menghadapi malapetaka, rela pada qada dan qadar, menyerahkan

30 Ibid., hlm. 58-59.

${ }^{31}$ Ibid., hlm. 43. 


\section{Basis Pemikiran Etika Religius Syaikh Yusuf}

semua urusan kepada Tuhan, berdzikir dan mendekatkan diri kepada Allah. Seperti dinyatakan dalam hadits: "Sembahlah Allah seperti engkau melihat Dia. Jika engkau tidak melihat Dia, sesungguhnya Dia melihat engkau. Ketahuilah itu semua." ${ }_{22}$

Dalam Sirr al-Asrar, Syaikh Yusuf menjelaskan:

Seorang salik itu harus tahu bahwa Allah itu bersamanya di mana pun ia berada, sebagaimana firman Tuhan: wahuwa ma'akum ainama kuntum. Juga sabda Nabi Saw.: "Iman yang terbaik bagi seorang hamba adalah agar ia mengetahui bahwa Allah bersamanya, di mana ia berada". Bagaimana Tuhan dapat bersama kita, bagaimana gambaran maiyyah itu, sedang Allah itu laisa kamitslihi syai'? ${ }^{33}$

... wajib atas salik untuk mengetahui bahwa setiap makhluk hidup itu bertasbih kepada-Nya. ${ }^{34}$

Pelaksanaan syari'at secara lahir (fiqh) haruslah selaras dengan kesucian hati (tasawuf). Hal ini diharapkan agar dapat mengantarkan salik mencapai tingkat makrifat atau pengetahuan yang hakiki tentang Tuhan. Dalam hal ontologi dan epistemologi Tuhan, alam, dan manusia, serta kaitannya dengan hal-hal yang perlu diperhatikan oleh seorang salik, Syaikh Yusuf dalam Tuhfat al-Abrar Li Ahli al-Asrar mengatakan:

.... la harus memiliki etika dan akhlak yang baik sebagaimana sabda Nabi Saw: "Aku diutus ke dunia ini untuk menyempurnakan akhlak yang mulia." Dan tasawuf adalah akhlak yang baik, yang tujuannya adalah menuju Allah dan berakhlak dengan akhlak Allah. Sabda Nabi Saw: "Allah mempunyai akhlak yang banyak. Siapa yang berakhlak dengan satu di antaranya, maka ia akan masuk surga". Seorang salik harus berprasangka baik terhadap Tuhan ataupun manusia, karena Allah tidak memaafkan orang yang menyekutukanNya. ${ }^{35}$

${ }^{32}$ Ibid., hlm. 58.

${ }^{33} \mathrm{Ibid}$., hlm. 68 dan Yusuf, bundle A, hlm. 101.

${ }^{34}$ Ibid., hlm. 101.

${ }^{35}$ Abdul Qadir al Jailani, Adab al Suluk wa Tawasul ila Manazil al Muluk, (Jakarta: Pustaka al Furqan, 2006), hlm. 256. 
Khan menyebutkan bahwa etika merupakan syarat yang ditekankan Syaikh Yusuf dalam rangka menuju kebenaran yang hakiki. Dan tarekat merupakan tahapan untuk menemukan apa yang benar dan apa yang salah.

Berkenaan dengan etika di dalam tahapan tarekat, Syaikh Yusuf menganjurkan sikap-sikap sebagaimana yang dijelaskan oleh Jailani, yakni beberapa cara yang dianjurkan oleh guru-guru sufi: saling menasehati dalam kebenaran dan kesabaran, bersahabat dengan orang fakir, dan melayani waliyullah, ketergantungan seorang hamba kepada orang yang berada di atasnya adalah kesombongan, ketergantungannya kepada yang setara adalah akhlak yang buruk. Oleh karena itu, kefakiran dan tasawuf itu berat, sehingga disarankan untuk tidak mencampuradukkan sedikit pun di antara keduanya. ${ }^{36}$

Hal-hal yang pantas diperhatikan oleh salik adalah:

a. Adanya keyakinan bahwa Sang Pencipta akan menanyakan segala gerak dan tindakan yang dilakukan seseorang.

b. Menyelamatkan anggota tubuhnya dari hal-hal yang tidak berguna dan akan merugikan dirinya sendiri.

c. Ketaatan kepada Allah dan rasulnya adalah suatu hal yang mutlak.

d. Memikirkan nasib umat Islam.

e. Tidak berburuk sangka serta berbuat baik dalam perkataan, pikiran, dan tindakan.

Dalam menjalani tarekat, ada etika yang perlu diperhatikan dan dilakukan oleh seseorang yang menempuh jalan tasawuf dalam tahapan tarekat, di antaranya adalah:

${ }^{36}$ M. Amin Al Kurdi, Tanwirul Qulub fi Muamalati Alllamin Ghuyub, (Jakarta: Penerbit Hikmah, 2003), hlm.299-307. 


\section{Basis Pemikiran Etika Religius Syaikh Yusuf}

a. Hendaknya seorang murid memuliakan gurunya dan mengagungkannya, baik secara lahir maupun batin. Di samping itu, sang murid harus meyakini bahwa ia tidak akan mencapai apa yang menjadi tujuannya kecuali di bawah bimbingan-Nya.

b. Patuh, tunduk, dan rela terhadap berbagai perlakuan sang guru dan memuliakan serta membantu sang guru dengan harta dan badan, karena esensi keinginan dan kecintaan itu tidak akan tampak kecuali dalam tindakan-tindakan.

c. Tidak menentang apa yang dilakukan sang guru.

d. Tujuannya hanyalah mendekatkan diri kepada Allah.

e. Menarik segala keinginannya dan memprioritaskan segala keinginan dan kebutuhan gurunya.

f. Tidak mengintai atau memata-matai segala aktivitas gurunya.

g. Menjaga kehormatan gurunya.

h. Melihat berkah dari segala perbuatan gurunya.

i. Menunggu jawaban gurunya dan tidak mendesaknya untuk segera memberikan jawaban bila bertanya.

j. Tidak menyebarluaskan kelemahan dan kejelekan gurunya.

k. Tidak menikahi perempuan yang disukai gurunya.

1. Tidak mengeluarkan pendapat kecuali diminta oleh gurunya, bahkan ia selayaknya menyerahkan jawaban itu kepada gurunya. Selain itu, ia layak memperhatikan segala hal dan kebutuhan gurunya dan bersikap jujur kepada guru beserta kerabatnya, menghormati pemberian gurunya, dan tidak bersahabat dengan orang yang dibenci gurunya.

Kurdi, seorang tokoh sufi, mengatakan bahwa seseorang haruslah memperhatikan etika atau moral yang baik ketika meniti jalan rohani, seperti menjaga hak-hak orang lain, tolong-menolong 
serta melakukan hal-hal terpuji lainnya dan menjauhkan dari halhal yang tercela. ${ }^{37}$

\section{Hakikat}

Menurut Syaikh Yusuf, hakikat adalah hati, batin atau gnosis (my heart). ${ }^{38}$ Hakikat mengacu pada makna terdalam dalam praktik dan bimbingan yang dibangun dalam syari'at dan tarekat. Hakikat adalah pengalaman langsung dalam kondisi mistis dalam sufisme dan pengalaman langsung dari kehadiran Tuhan dalam diri. Tanpa pengalaman ini, para murid hanya mengikuti secara buta, berusaha meniru orang yang telah mencapai tingkatan (maqam) hakikat. Pencapaian hakikat memperkuat dan memperkokoh laku pada dua tingkatan, yaitu sebelum sampai pada hakikat, seluruhnya adalah peniruan. Tanpa pemahaman batin yang mendalam dan lahir dari pengalaman, maka orang hanya mengikuti ajaran dan laku orang lain secara mekanistis. ${ }^{39}$

Oleh karena itu, beberapa pernyataan di bawah ini sangat penting untuk diperhatikan:

a. Hati merupakan unsur utama dalam meraih hakikat, karena hati itu ibarat bejana.

b. Hati orang kafir adalah bejana terbalik yang tidak bisa dimasuki satu kebaikan pun.

c. Hati orang munafik adalah bejana pecah yang apabila dituangkan sesuatu dari atas akan merembes keluar dari bawah.

d. Hati orang beriman adalah bejana yang baik dan seimbang sehingga dapat menampung kebaikan yang dituangkan di atas

\footnotetext{
${ }^{37}$ Yusuf dalam Tudjimah, hlm. 42.

${ }^{38}$ Fadiman, hlm. xxi.

${ }^{9}$ Abdul Aziz Al Daniri, Thahatul Qulub wa Khudu' li Aallamil Ghuyub, (Bandung: Mizan, 2004), hlm. 82-83.
} 


\section{Basis Pemikiran Etika Religius Syaikh Yusuf}

hatinya. Hati kaum yang beriman bersih dari kelalaian dan kecerobohan sehingga bisa menjaga kesucian sesuatu yang dituangkan ke dalamnya. Hati kaum yang memiliki sedikit kotoran akan mencemari sesuatu yang dituangkan ke dalamnya. Hati kaum yang banyak memiliki kotoran akan mengotori semua kebaikan yang dituangkan ke dalamnya.

Jika hati kotor, tidak ada sedikit pun ruang untuk yang lain. ${ }^{40}$ Dengan demikian, penyucian hati berkaitan erat dengan usahausaha lahir dan batin yang dilakukan seseorang, misalnya berdoa dan berdzikir. Doa memiliki aspek lahir dan batin, yaitu doa yang diucapkan (lahir) dan keikhlasan (batin). ${ }^{41}$

Dalam Daf al-Bala, Syaikh Yusuf mengatakan: “Tiap-tiap wali dari waliyullah yang arif mempunyai kesibukan dan kebiasaan. Kesibukan yang tertinggi adalah shul al-ashghal, karena firman Allah: Wa kanallahu bi kulli syai’n muhith. Maksudnya, kiblat (orientasi batin) itu ada tiga, pertama, kiblat al-amal atau kiblat awam. Firman Allah: "Hadapkanlah wajahmu ke masjid Haram." Shalat tidak akan sah kecuali menghadap kiblat ini pada lahirnya. Kiblat ini dapat jauh atau dekat dari orang yang shalat.

Kedua, kiblat al-ilm atau kiblat khawas. Firman Allah: "Ke mana engkau hadapkan wajahmu, maka sempurnakanlah wajah Allah". Hanya orang yang khawas yang mengerti rahasia ini. Ketiga, kiblat sirr, yaitu Allah itu sendiri, yaitu Dia yang awal dan yang akhir, yang lahir dan yang batin. Firman Allah: "Aku lebih dekat daripada kamu sekalian, sedang kamu tidak melihat”. "Aku lebih dekat daripada urat nadi kalian semua." 43

\footnotetext{
${ }^{40}$ Annemarie Schimmel, I am Wind, You Are Fire, (Bandung: Mizan, 2008), hlm. 228-229.

41 Ibid., hlm.232

${ }^{42}$ Yusuf dalam Tudjimah.

${ }^{43}$ Ibid., hlm. 88.
} 
Syaikh Yusuf menjelaskan tingkatan dan macam-macam kiblat dalam menyembah Allah. Orang-orang awam hanya memusatkan diri pada kiblat lahir (ka'bah dan Masjid Haram di Makah). Sementara muslim yang mencapai tingkatan khusus, selain memusatkan diri pada kiblat lahir, juga memusatkan hatinya kepada Allah. Tingkatan yang tertinggi adalah seorang hamba yang dapat memusatkan hatinya untuk menjadi kiblat dalam pengabdian kepada Allah, dan ia akan sampai pada taraf pencapaian hakikat kebenaran, karena memperhatikan seluruh tingkatan dalam peribadatan kepada Yang Maha Benar. ${ }^{44}$

Terkait dengan maqam, Syaikh Yusuf kembali mengulang pentingnya keyakinan akan eksistensi Allah. Allah merupakan wujud yang tidak tertandingi dan tidak dapat digambarkan, karena Dia memiliki sifat meliputi segala sesuatu. Selain itu, pengetahuan bahwa Allah tidak sama dengan suatu apapun merupakan pengetahuan yang akan membawa seorang muslim pada pemahaman akan kebenaran, terutama yang berkaitan dengan ontologi dan epistemologi Tuhan, alam, dan manusia.

Dalam Risalah Gayat al-Ikhtisar wa Nihayat al-Intizar, Syaikh Yusuf menerangkan tentang hakikat. Pertama, talib (yang menuju Allah) yang disebut a'yanu at-thabita. Kedua, ilmu Ilahiyah itu qadim, karena zat-Nya itu qadim. Ketiga, hakikat dalam bahasa itu bukan benda itu sendiri: ia itu Ia. Keempat, wujud alam, termasuk manusia, itu wajib, sedangkan yang diketahui itu mesti maujud. Penjelasan tentang keempat hal tersebut, dapat dilihat dalam kutipan berikut ini:

Ketahuilah, talib (yang menuju Allah) yang disebut a'yanu at thabitah bagi orang 'arif billah itu gambaran bentuk yang diketahui atau dikenal dari benda-benda dalam pengetahuan Allah yang qodim dan azali. Ilmu Ilahiyyah itu qodim, karena zat-Nya itu qodim,

${ }^{44}$ Ibid., hlm 89. 


\section{Basis Pemikiran Etika Religius Syaikh Yusuf}

sedangkan hubungannya dengan a'yanu thabita dan sifatnya al a'yanu itu karena ia tetap di dalam ilmu Ilahi, tidak lepas dan keluar daripadanya sama sekali dari azali dan abadi. Arti dari al-a'yanu di sini: benda-benda yang ada di dalam ilmu. la mempunyai namanama lain dari jumlah al ma'lumatal ilmiyyah.

Hakikat dalam bahasa itu bukan benda itu sendiri: ia itu la. Dalam istilah orang-orang arif billah yang sempurna, hakikat itu dengan siapa benda itu berdiri, dan hak Allah itu hakikatnya benda-benda dan benda-benda itu berdiri karena Allah azza wa jalla. Ketahuilah itu. Adapun perkataan hudustiah-nya dengan ibarat bekasnya di luar, maka itu betul dari sudut namanya al-muathir dengan nama athar jaiz. Seperti perkataan: qadimnya alam dengan ibarat hakikatnya tetap dalam ilmu Ilahiyyah yang qadim dan azali. Itu dinamakan al -a'yanu thabitah oleh ahli fana ini seperti tersebut di atas dari sudut nama alathar dengan nama al-muathir. Jika kamu raru-ragu, kita buat contoh supaya engkau paham. Seorang laki-laki masuk ke dalam hutan. la melihat telapak singa di atas tanah dan berkata: Ini singa. Padahal di dalam perkataannya bagi orang yang arif dan kata-katanya itu tidak diingkari oleh seorang pun. Ketahuilah itu. ${ }^{45}$

Kutipan di atas memperlihatkan bahwa konsep Syaikh Yusuf tentang Tuhan bercorak sintesis antara paham ta'thil (pengosongan Tuhan dari sifat-sifat) dan paham tasybih (penyerupaan-Nya dengan makhluk dalam sifat). Tuhan adalah Zat Yang Maha Suci tanpa ta'thil dan memiliki keserupaan tanpa kesamaan. Sebab, kemutlakan menyebabkan terjadinya keserupaan. Oleh karena itu, hakikat pandangan ini mengajarkan etika mengenal Ilahi, yaitu:

a. Manusia tidak boleh melepaskan diri dari prinsip kecil (tidak ada apa-apanya) di hadapan Tuhan.

b. Kemutlakan Tuhan berada di antara kenisbian manusia.

c. Tuhan adalah Zat Yang Maha Suci dan memiliki keserupaan tanpa kesamaan.

d. Tuhan tidak memiliki sifat-sifat terbatas, karena membatasi sifat Tuhan hanya akan menghambat jalan menghampiri-Nya.

${ }^{45}$ Ibid., hlm. 96-97. 
Syaikh Yusuf menegaskan bahwa prinsip akidah yang paling pokok adalah mempercayai bahwa Tuhan adalah Zat yang maujud, qadim dan azali, bersifat mandiri dan menjadi tumpuan utama segala sesuatu, bersifat unik (laysa kamitslihi syai'un). Kesempurnaan Tuhan merupakan hakikat (a'yanu) kemutlakan-Nya.

Berkata beberapa orang ahli ilmu, bahwa wujud alam ini wajib. Maka dijawab: Betul jika ia tahu apa yang dimaksud dengan kata-kata itu. Ini ibarat ciptaan Allah terhadapnya. Jika ia menemukan Allah, maka ia harus ada, karena adanya Allah Ta'ala, wujudnya itu ibarat wajib, tidak mungkin. Betul wujud alam itu mungkin sebelum ada hubungan dengan ciptaan Tuhan, tetapi sesudah adanya alam itu wajib dengan wujudnya karena Allah, artinya bahwa alam ini harus ada karena dicipta oleh Allah al-Malik, yang berkuasa, yang berkehendak, dan bijaksana. Adapun perkataan adamiyyah-nya atau tidak adanya itu ibarat tidak ada wujudnya di luar. Sedangkan perkataan wujudiah-nya itu ibarat maklumiyyah-nya, sedangkan yang diketahui itu mesti maujud. Adapun perkataan tidak ada qadimahnya dan tidak ada hudutsiah-nya.

Menurut qawaid istilah ahlul kamal yang arif: yang qadim wujudnya di luar itu hanya Hak Allah Ta'ala, sedangkan yang hadits dan maujud di luar itu hanya alam. Maka a'yanu tahbitah itu bukan Hak Ta'ala sehingga qadim maujud di luar dengan sendirinya (Yusuf, dalam Tudjimah, 1997: 97).

...la juga bukan alam sehingga ia hadits maujud di luar. $A^{\prime} y a n u$ thabitah itu tidak berbau maujud di luar sama sekali, qadim atau hadits. Maka betul untuk dikatakan bahwa a'yanu thabitah itu tidak qadim dan tidak hadits. Ketahuilah itu. Seperti alam itu pada hakikatnya tidak maujud dan tidak ma'dum mutlak. Ketahuilah itu. Ini sangat berharga. Yang dapat mengerti hal ini hanya yang ahli. Jika ada yang berkata, kita paham semua yang dikatakan dalam risalah ini dengan pertolongan Hak Ta'ala, maka yang dibicarakan itu bukan firman Tuhan: Kun, dengan perintah yang berbicara. Jika kita berkata, perkara itu menunjukkkan bahwa ia berbicara mengenai sesuatu yang maujud, maka Hak Ta'ala harus tidak dapat mencipta dan membuat tidak ada kalau Dia mau. Dan ini sulit untuk diridhai. Jika kita berkata bahwa pembicaraan mengenai firman Ilahi itu sesuatu yang tidak ada, maka firman Ilahi itu hanya perm a'yanu karena bicara mengenai sesuatu yang tidak ada, sedang kata-kata itu ada dan Hak Ta'ala itu bijaksana dan Maha Tahu, tidak ada perm a'yanu dalam pekerjaannya semua 


\section{Basis Pemikiran Etika Religius Syaikh Yusuf}

sama sekali. Ini muskil juga. Bagaimana itu, maka jawabnya bahwa yang dibicarakan dalam firman Ilahi itu sudut wujudiyyah-nya. ${ }^{46}$

Sebagai kesimpulan, al-a'yanu thabita itu mempunyai dua sudut: wujudiyah dan wujud adamiyah. Dari sudut wujudiyah, Allah berfirman, dan Kun dari sudut adamiyyah. Maka benar jika dikatakan bahwa hak Ta'ala membuat barang-barang dari ada pada wujud atau dari wujud dalam ilmu Ilahiyah. Jika dikatakan mengapa alam itu disebut bayangan Allah, bayangan itu bentuknya seperti yang empunya: sedang Allah itu laysa kamitslihi syaiun. Maka dikatakan bahwa perkara itu tidak dipahami. Ia disebut begitu karena mempunyai tiga hal: pertama, bahwa bayangan itu tidak berdiri sendiri, tetapi berdiri dengan Yang Empunya bayangan. Begitu pula alam, tidak berdiri sendiri, tetapi berdiri karena Allah Yang Maha Kuasa. kedua, bahwa bayangan itu tidak bergerak kecuali kalau yang empunya itu bergerak. Begitu pula alam, tidak berbuat atau berkehendak sesuatu, kecuali dengan kehendak Allah dan kodrat-Nya. Ketiga, bayangan itu bertambah banyak karena banyaknya yang melihat, sedang Yang Empunya bayangan tidak bertambah banyak, karena banyaknya yang melihat. Inilah persamaan dari sudut itu, bukan dari yang lain.

Konsep-konsep kosmologi dan antropologi Syaikh Yusuf tampaknya terpengaruh oleh pandangan Ibn Arabi, meskipun tidak ditemukan tulisan Syaikh Yusuf secara komprehensif mengenai hal ini. Menurut Syaikh Yusuf, alam secara keseluruhan diciptakan oleh Tuhan dengan perintah Kun. Objek perintah itu ditujukan pada al-a'yanu al-tsabitah (hakikat alam sebelum berwujud secara nyata), yang tampak dengan dua wajah: pertama adalah segi keberadaannya (wujudiyahtuha) dan kedua, adalah segi ketiadaannya (adamiyahtuha). Dari segi yang pertama itulah perintah Kun ditujukan, sedangkan dari segi yang kedua, ia

\footnotetext{
${ }^{46}$ Ibid., hlm. 98.
} 
menerima perwujudan dari Tuhan. Oleh karena itu, wujud alam ini bisa dikatakan wajib berada (wajibu al-wujud) dan bisa juga dikatakan mungkin berada (mumkin al-wujud). Dikatakan wajib karena dilihat dari sudut perintah dengan kata Kun, alam pasti dan harus berwujud. Disebut mungkin, dilihat dari segi keadaannya sebelum menerima perintah perwujudan dari Tuhan (lihat, Ghayat al-Ikhtisar wa Nihayat al-Ikhtisar, Taj al-Asrar fi Tahqiq Masyrab al-Arifin min Ahl al-Istibshar, dan naskah Zubdat al-Asrar).

Dapat dikatakan bahwa Allah menciptakan alam secara keseluruhan dari ketiadaan. Hal ini merupakan pembahasan filsafat tentang keberadaan alam yaitu, creatio ex nihilo, alam diciptakan dari ketiadaan. Tetapi, dari sudut yang lain dapat dikatakan bahwa alam ini dari suatu wujud ke wujud yang lain, yakni dari wujud ilmunya Tuhan yang diisyaratkan sebagai wujud yang dirahasiakan menjadi wujud yang nyata. Pesan yang ingin disampaikan oleh Syaikh Yusuf dalam hal ini adalah persoalan seperti ini hanya bisa diterima oleh orang yang benar-benar mengetahui hakikat persoalan. Seluruh penciptaan akan berujung pada Sang Pencipta yang tidak diciptakan. Sebab, dalam perdebatan filosofis disebutkan bagaimana sesuatu yang tiada dapat mengadakan sebuah keberadaan, tentu ada causa prima dalam hubungannya dengan kehidupan manusia.

Konsep-konsep tersebut menjadi titik tolak munculnya etika religius dalam hubungannya dengan sikap dan perilaku manusia. Penciptaan alam dan hubungannya dengan tindakan manusia serta tanggung jawabnya telah menjadi perdebatan panjang sejak filosoffilosof Yunani mempertanyakan keberadaan alam dan Tuhan. Puncaknya, Socrates yang tidak percaya akan keberadaan dewadewa Yunani akhirnya mati dengan meminum racun, disusul kemudian oleh Sartre yang membahas tentang ada dan tiada (keberadaan dan ketiadaan). 
Sehubungan dengan hal tersebut di atas, Syaikh Yusuf menjelaskan bahwa siapa pun yang telah mengetahui hakikat Tuhan, ia akan mencapai tingkatan yang lebih tinggi, yakni mengetahui hakikat kebenaran tentang Tuhan. Kebenaran yang tertanam di dalam hati dan diwujudkan dalam peribadatan seharihari, memberi gambaran bahwa orang di masa lalu memiliki gambaran filsafat sebagai mitos sebagaimana dilakukan di Yunani dengan cerita-cerita tentang dewa dewi, dan bahkan di pahatanpahatan kayu dan batu. Kebenaran-kebenaran itu ditonjolkan dalam gambar-gambar yang diukir di tempat-tempat peribadatan. Gambar yang berfungsi sebagai simbol merupakan doa bagi pemeluk agama tersebut. Inilah yang membedakan Islam dari agama lain.

\section{Makrifat}

Dalam al-Nafhat al-Sailaniyya, Syaikh Yusuf memaknai kata "makrifat" sebagai rahasia atau hakikat (gnosis). ${ }^{47}$ Makrifat adalah kearifan puncak atau pengetahuan tentang kebenaran spiritual. Makrifat adalah level yang paling dalam dan tinggi dari pengetahuan batin dan melampaui hakikat. Makrifat lebih dari sekadar pengalaman spiritual sesaat, dan makrifat merujuk pada kondisikondisi keselarasan dengan Tuhan dan kebenaran. Makrifat adalah pengetahuan tentang realitas yang dapat dicapai oleh hanya sedikit orang. Makrifat merupakan tingkatan para nabi, rasul, waliyullah, dan para bijak.

Tahapan makrifat memungkinkan seseorang yang telah sampai kepada-Nya, menyebut Tuhan dengan sepenuh hati. Seseorang akan menemukan cahaya Ilahiyah, yaitu jalan kebenaran dalam kehidupannya. Makrifat merupakan jalan

${ }^{47}$ Ibid., hlm. 42. 
mengenali zat dan sifat-Nya secara benar, karena mengenal Allah merupakan suatu pengetahuan yang paling sulit. Hal ini karena tidak ada sesuatu pun yang menyamai eksistensi Allah. ${ }^{48}$ Allah memuji hamba yang mengenali-Nya. Sebaliknya, Dia mencela hamba yang tidak mengenali-Nya dan mengingkari-Nya. 49

Makrifat Allah itu ada dua macam, bersifat umum dan bersifat khusus. Makrifat yang pertama wajib dimiliki setiap mukalaf, yakni mengakui eksistensi-Nya dari segala sesuatu yang tidak sesuai dengan-Nya serta mengakui segala sifat yang telah ditetapkan untuk diri-Nya. Makrifat yang kedua adalah kondisi menyaksikan Allah.

Ahli makrifat adalah orang yang mempunyai kemampuan untuk menyaksikan zat, sifat, dan perbuatan-Nya, sedangkan orang alim adalah orang yang dikaruniai pengetahuan melalui keyakinan, bukan dengan penyaksian. Pendapat lain menyebutkan bahwa makrifat adalah suatu keyakinan yang muncul setelah perjuangan ibadah. Menurut Imam al-Ghazali, Allah terlalu besar untuk dapat ditangkap oleh pancaindra, akal, dan analogi, bahkan keagunganNya terlampau besar untuk dapat dijangkau oleh selain-Nya. ${ }^{50}$

Tidak ada yang dapat mengetahui hakikat wujud Allah kecuali Allah sendiri. Puncak pengetahuan hamba akan sampai pada suatu kesadaran bahwa akan sangat mustahil untuk mencapai makrifat yang hakiki. Secara sempurna hal itu disadari oleh para nabi dan orang-orang yang shidiq (benar). Nabi misalnya pernah bersabda: "Aku tidak pernah dapat memberikan pujian yang cukup kepadaMu. Engkau seperti pujian yang Engkau berikan untuk diri-Mu”. Abu Bakar pernah berkata: "Adapun ketidakmampuan untuk

\footnotetext{
${ }^{48}$ Q.S. al-Isra: 44.

${ }^{49}$ Iskandari (2006), hlm. 121.

50 Ibid., hlm. 122.
} 


\section{Basis Pemikiran Etika Religius Syaikh Yusuf}

mengenal-Mu adalah pengetahuan itu sendiri". ${ }^{51} \mathrm{Jadi}$, makrifat merupakan istilah yang digunakan oleh para sufi, yang berarti pengetahuan yang sebenarnya tentang Tuhan melalui hati sanubari. ${ }^{52}$

Berkaitan dengan makrifat, qalbu atau jiwa menurut kaum sufi adalah sebagai instrumen penting karena dengan jiwa, salik dapat menghayati segala rahasia yang ada di dalam alam gaib, dan puncak penghayatannya adalah makrifat kepada Tuhan. Menurut kaum sufi, dalam hati sanubari terdapat kekuatan yang disebut ruh yang berfungsi untuk mencintai atau rindu kepada Tuhan. Di dalam ruh terdapat sirr atau rahasia yang berfungsi untuk berpikir tentang Tuhan sehingga seorang sufi dapat berkomunikasi dengan Tuhan. 53

Untuk mencapai tingkat makrifat, Syaikh Yusuf menyatakan dalam Tahsil al-Inayat wal Hidayah:

Seorang hamba yang berakal jika ingin menjadi waliyullah, maka ia harus banyak berdzikir kepada Allah. Seorang hamba yang berdzikir harus tahu dan percaya pada ayat: laysa kamitslihi syai, dan pada surat al-Ikhlas, karena semua kepercayaan kepada Allah kembali pada ayat dan surat tersebut.

Jika ingin berdzikir kepada Allah, pilihlah dzikir yang termulia, yaitu: La ilaaha illa Allah. Dizkir itu sesungguhnya iman itu sendiri. Kemudian ia harus menjalani lahirnya dan batinnya syari'at yang suci dengan memegang teguh hakikat yang suci. la juga harus memberatkan akhirat daripada dunia dan mencintainya dengan cinta yang benar dan ikhlas. ${ }^{54}$

51 lbid., hlm. 123.

${ }^{52}$ Masyharuddin, Pemberontakan Tasawuf, Kritik Ibnu Taimiyah atas Rancang Bangun Tasawuf (Kudus: STAIN Press, 2007), hlm. 151.

53 Ibid., hlm. 152.

${ }^{54}$ Yusuf, hlm. 94. 
Menurut Syaikh Yusuf, tahap akhir pencarian kebenaran disebut makrifat. Hamba yang telah mencapai makrifat, ia disebut waliyullah. Jika telah mencapai derajat waliyullah, berarti ia telah mencapai derajat tertinggi di bawah kenabian. Artinya, seseorang yang telah mencapai derajat wali akan sepenuh hati mencintai Allah dan nabi-Nya. Ia akan memegang teguh syari'at secara lahir dan batin serta tidak terlalu mencintai dunia. Apapun yang dikerjakannya diniatkan ikhlas untuk mencapai keridaan Allah.

Sehubungan dengan etika hubungan antara manusia dan Tuhan, dan antarmanusia sendiri, Syaikh Yusuf mengutip hadits, yang artinya:

Sesungguhnya oarang yang tinggi derajatnya adalah ahli suluk dan mampu menyembah Allah seakan-akan engkau melihat-Nya. Selain itu, diwajibkan juga bersikap baik kepada manusia, misalnya berbaik sangka. ${ }^{55}$

Karena Allah memerintahkan akhlak atau etika yang mulia, Syaikh Yusuf berkata:

Akhlak yang mulia terhadap sesama manusia membawa pula untuk berakhlak dengan akhlak Allah. Ini sesuai dengan hadits, "Sesungguhnya Allah mempunyai akhlak yang banyak, barangsiapa mempunyai salah satu dari akhlak itu, ia masuk surga". Karena tasawuf sendiri adalah permulaannya memurnikan niat kepada Allah Ta'ala, dan akhirnya adalah berhias dengan akhlak Allah". ${ }^{56}$

Tujuan utama dari perjalanan hamba dalam suluknya adalah untuk bertemu dengan Tuhan, sehingga ia harus berbekal akhlak Tuhan itu sendiri. Orang yang telah mencapai puncak perjalanan suluknya, ia akan mengalami kefanaan dalam diri Tuhan serta kebaqa'an dengan-Nya, yaitu:

\footnotetext{
${ }^{55}$ Yusuf, dalam Zubdatul Asrar, Bundel A, hlm. 101. 56 Ibid.
} 


\section{Basis Pemikiran Etika Religius Syaikh Yusuf}

a. Ia akan tenggelam dalam tajalli kebesaran Tuhan Yang Maha Indah serta penyaksiannya yang tetap dalam suatu maqam, seolah-olah ia adalah Tuhan karena ia telah disifati dengan sifatsifat-Nya.

b. Dalam hal seperti ini orang yang berdzikir akan disifati dengan sifat-sifat-Nya berubah menjadi dizikir.

c. Selanjutnya, yang mengenal menjadi dikenali.

d. Terus meningkat, yang memandang atau si pemandang akan menjadi dipandangi.

e. Lalu, yang menyaksikan atau si penyaksi menjadi disaksikan.

f. Yang berkehendak atau si berkehendak menjadi dikehendaki.

g. Si pencinta menjadi dicintai.

h. Perasaan yang paling indah dan hakiki adalah: Tuhan adalah hamba dan hamba adalah Tuhan.

Menurut Syaikh Yusuf, hal-hal yang disebut di atas bukan karena kehendak atau kemauan manusia, melainkan Tuhan-lah yang ber-tajalli dan berbicara melalui lidah hamba-Nya. Tentu saja, hamba yang telah mencapai tingkat al-'arifu billahi, al-wali, atau al-insanu al-kamil. ${ }^{57}$ Pandangan Syaikh Yusuf ini tampak memiliki kesamaan dan bersumber dari dari pemikiran mistik Ibn Arabi yang kemudian dimatangkan oleh al-Jilly. ${ }^{58}$

Al-Ghazali menjelaskan makrifat dengan mengibaratkan qalbu sebagai cermin, sementara pengetahuan yang ditangkap qalbu adalah realitas yang terdapat di dalam cermin qalbu. Karena itu, jika cermin hati kotor, ia tidak dapat memantulkan realitas pengetahuan. Menurutnya, yang membuat cermin qalbu tidak bersih adalah hawa nafsu dan tubuh. Ketaatan kepada Allah serta

${ }^{57}$ Cawidu, hlm. 8.

58 Ibid. 
berpaling dari tuntutan hawa nafsu itulah yang membuat qalbu bersih sehingga dapat menangkap pengetahuan Tuhan. ${ }^{59}$

Al-ghazali memasukkan makrifat ke dalam ilmu mukasyafah atau penyingkapan. Ia menjelaskan bahwa fenomena memperoleh makrifat sebagai ilmu kasyf adalah terbukanya tabir rahasia Ketuhanan bagi para wali, yang berupa penyaksian berbagai keajaiban surgawi dan keadaan yang dialami orang-orang yang meninggal dunia. Makrifat merupakan pengetahuan penyaksian (musyahadah) yang diperoleh melalui pengalaman secara langsung terhadap objek yang diketahui, terutama Tuhan. ${ }^{60}$

Secara etimologis, makrifat adalah pengetahuan tanpa keraguan sedikit pun. Dalam terminologi kaum sufi, makrifat disebut pengetahuan yang tidak disertai keraguan di dalamnya ketika pengetahuan itu berkaitan dengan zat Allah dan sifat-sifat-Nya. ${ }^{61}$

Tingkatan makrifat itu berbeda-beda. Tingkat penyaksian seseorang juga berbeda, bergantung pada kualitas penempatan diri dan perbuatan mulia (tahalli). Orang yang ingin menyalakan lentera, tentunya ia membutuhkan tujuh sarana untuk melakukannya, seperti batang kayu, batu pembakaran, korek, tiang, sumbu, dan minyak. Bila seseorang ingin mendapat lentera makrifat kepada Allah, pertama, ia harus memiliki semangat perjuangan yang tinggi. Karena dengan semangat itu, dan juga karena Allah, jalan keluar dari permasalahan akan ditunjukkan oleh Allah. "Orang-orang yang berusaha mencari ridla Kami, akan Kami tunjukkan kepada mereka jalan-jalan Kami” (QS. al-Ankabut: 69).

Kedua, seseorang haruslah memiliki kerendahan hati di hadapan Allah. Seperti penegasan al-Qur'an: “Berdoalah kepada

\footnotetext{
${ }^{59}$ Masyharuddin, hlm. 152.

${ }^{60}$ Ibid., hlm. 154.

${ }^{61}$ Imam al Gazali, Kimiyyah al Sa'adah wal Mawaidz fi al Ahadist al Qudsiyyah (terj.) (Jakarta: Serambi Ilmu, 2007), hlm. 225.
} 


\section{Basis Pemikiran Etika Religius Syaikh Yusuf}

Tuhanmu dengan merendahkan diri dan dengan suara yang lembut” (QS. al-A'raf: 55). Ketiga, nyala api yang dibutuhkan berarti terbakarnya hawa nafsu. Al-Qur'an menyatakan: "Dan orang-orang yang menahan diri dari hawa nafsunya” (QS. anNaziat: 40).

Keempat, kembali kepada Allah dalam setiap urusan. "Kembalilah kalian kepada Tuhan kalian" (QS. az-Zumar: 54). Kelima, tiang kesabaran. Seseorang harus memiliki tiang kesabaran dalam menghadapi hidup. “... sesungguhnya Allah beserta orang-orang yang sabar” (QS. al-Anfal: 46). Keenam, bumbu kesyukuran. Seorang hamba harus selalu bersyukur kepada Allah dalam berbagai keadaan. "Bersyukurlah kamu sekalian terhadap nikmat Allah” (QS. an-Nahl: 114). Ketujuh, seorang hamba membutuhkan minyak keridhaan, yaitu perasaan ridha terhadap ketentuan yang telah ditetapkan Allah dan takdir yang diterima. Jika takdir jatuh padanya, maka perintah kesabaran berkaitan erat dengan takdir yang telah ditentukan. "Keharusan bersabar terhadap ketentuan Tuhan” (QS. at-Thur: 48).

Berdasarkan al-Qur'an, para sufi mengemukakan deskripsi tentang Tuhan sebagai yang pertama, yang terakhir, yang lahir, yang batin. Penekanan pada pendapat bahwa Tuhan adalah aspek batin dari segala sesuatu membutuhkan artikulasi hubungan antara yang lahir dan batin. Hal ini terpantulkan sepenuhnya dalam struktur tiga serangkai yang sering digunakan dalam pengajaran. Bentuk lahir adalah hukum syari'at, sedangkan pendekatan batin adalah jalan tarekat. Tuhan adalah realitas-Nya (hakikat). Rumusan ini menjadikan sufi menganggap praktik-praktik yang berbeda sebagai internalisasi ritual-ritual lahir kehidupan religius muslim.

Sufisme merupakan jalan dalam berproses dari kehidupan untuk menemukan realitas batin Tuhan. Tingkat hierarki realitas semacam ini sama dengan teori esoterisme. Kedudukan orang yang tahu dan yang tidak tahu menjadi penting dalam konteks 
keberagamaan. Hal ini ditegaskan oleh Al-Qur'an dengan kalimat filosofis yang retorik: "Apakah sama, mereka yang mengetahui dengan yang tidak mengetahui ?” (Q.S. az-Zumar: 9). Dalam dunia filsafat, kaum filosof yang lebih mengerti tentang persoalan, memiliki kedudukan yang lebih tinggi dari filosof lainnya, sebagaimana Socrates yang dianggap manusia paling bijak oleh Plato dan murid-muridnya karena Socrates memiliki pengetahuan yang lebih baik dari yang lain. Sehubungan dengan konsep hakikat dan makrifat yang menjadi tujuan para sufi, tidak hanya mengandalkan ibadah secara jasmani dan hati, tetapi juga pemahaman intelektual dan filsafati yang benar tentang keberadaan dan hakikat Tuhan.

Penting untuk diketahui bahwa metafor realitas dan pengetahuan batin membutuhkan bentuk-bentuk lahirnya, agar semuanya menjadi masuk akal dalam pelaksanaannya. Kenyataan tentang sufisme oleh golongan sufi tersebut mengisyaratkan adanya norma-norma atau etika yang harus diperhatikan oleh tradisi Islam. Namun pada saat yang sama terkadang berada di luar kebiasaan mayoritas masyarakat Islam dalam menjalankan kewajiban-kewajiban agama, terutama dalam hal pendekatan diri kepada Allah. ${ }^{62}$

Sufisme sebenarnya dapat digambarkan sebagai kesungguhan moral dan etika dan kaitannya dengan interiorisasi (penghayatan) keimanan. Sufisme menekankan spiritualitas yang didasarkan dengan kuat pada Al-Qur'an dan keyakinan adanya sebuah ikatan esensial di antara seluruh muslim yang hidup sesuai dengan panggilan prinsip-prinsip Islam. Sufisme yang sesungguhnya juga mengandung kritik kepada orang-orang yang tidak mengaitkan Islam dengan aktivitas dan komitmen kaum sufi yang menyandar-

${ }^{62}$ Ibid., hlm.315. 


\section{Basis Pemikiran Etika Religius Syaikh Yusuf}

kan keselamatan pada keanggotaan tarekat tertentu walaupun menyimpang. ${ }^{63}$

Berkaitan dengan hal tersebut, Abdul Qadir Jailani mengingatkan untuk tidak berambisi masuk ke dalam golongan orangorang ruhaniyyin (spiritual) sampai benar-benar pantas menjadi musuh ego dan benar-benar terlepas dari semua kebutuhan organorgan tubuh. Artinya, bila seseorang ingin menapaki jalan rohani, maka ia harus benar-benar terlepas dari ego dan keinginan ragawi yang berlebihan, serta memusatkan diri hanya mencari keridhaan Allah dalam segala gerak-geriknya. Ia harus menundukkan syahwat materi dan non-materi yang masih terdapat dalam dirinya. Berusaha untuk memisahkan segala keinginan syahwat duniawi yang tidak ada kaitannya dengan jalan menuju Tuhan. Dengan usaha, seseorang dapat menempatkan rohaninya dalam diri dan dapat menjadi panglima dalam kehidupannya sehari-hari serta dapat mengontrol keinginan ragawi, maka jalan menuju Tuhan akan tercapai, karena segala tabir telah tersingkap. Bila seseorang telah dapat mencapai tingkat rohani seperti ini, maka ia telah dapat menyingkapkan penghalang dan segala kegelapan antara dirinya dan Tuhannya. ${ }^{64}$

Tahap pencapaian seperti disebutkan diatas pernah dialami oleh Nabi Ibrahim ketika sampai pada pemahaman sempurna akan Tuhan. Proses pencarian Ibrahim tentang Tuhan diabadikan dalam Al-Qur'an dengan pernyataan Ibrahim: "Sesungguhnya mereka semua adalah musuhku kecuali Tuhan semesta alam. Dia berkata demikian pada berhala-berhala itu” (QS. as-Syura: 77).

Pengalaman spiritual Nabi Ibrahim di atas mengandung pesan yang sangat jelas, yaitu agar tidak menjadikan segala keberadaan

\footnotetext{
${ }^{63}$ Ghazali, hlm.50.

${ }^{64}$ Ernst, Carl W, The Shambala Guide to Sufism (terj.) (Yogyakarta: Pustaka Sufi, 2003), hlm. 23.
} 
dan bagian-bagian diri dan ciptaan-ciptaan lain sebagai berhala dan tidak ingkar kepada Tuhan. Dengan demikian, maka makrifat Tuhan akan dikaruniakan bagi orang-orang yang mengikuti teladan Ibrahim dan nabi-nabi lainya dan diberikan daya cipta yang kreatif serta diberikan hikmah sebagaimana Allah mengaruniakannya kepada ahli-ahli surga. Keberadaan seorang hamba dalam kondisikondisi seperti ini ibarat jiwa yang terbangkitkan dari kematian di akhirat. Seseorang yang ingin mencapai makrifat, maka ia harus menjadi perwujudan kuasa Allah:

a. Menjadikan seluruh tindakannya berdasarkan keinginan Allah.

b. Menjadi tuli dengan sesuatu kecuali Dia,

c. Dengan demikian, seseorang akan menjadi tuli dengan sesuatu kecuali Tuhan, tidak mendengar kecuali dengan pendengaranNya, dan tidak bertindak kecuali dengan arahan dan bimbinganNya. Hal ini berarti seseorang telah mengetahui hukum-hukum Tuhan dan mengetahui segala hak dan kewajibannya kepada Tuhan dan manusia dalam menjalankan hukum-hukum tersebut. Sebab, segala sesuatu yang tidak memiliki landasan dalam hukum Tuhan yang benar adalah suatu kekafiran. ${ }^{65}$

Sehubungan dengan hakikat Tuhan, Jalaluddin Rumi memandang bahwa hanya ada satu Tuhan yang maha kuasa yang menjadi sumber hikmah. Untuk mencapai Tuhan, seseorang harus memperhatikan batinnya. Asal-usul segala kejahatan di dunia ini adalah nafsu syahwat. Namun, dalam jiwa manusia juga ada yang disebut ruh, yaitu pemberian kekuasaan Tuhan untuk mengatasi nafsu itu. Perjuangan antara nafs dan ruh merupakan tantangan dan penentangan dari segala aspek-aspek yang membentuk tujuan hidup manusia. Dalam menghadapi tantangan ini maka perlu disadari sepenuhnya bahwa halangan yang paling berat adalah

${ }^{65}$ Ibid., hlm. 30-31. 


\section{Basis Pemikiran Etika Religius Syaikh Yusuf}

penipuannya oleh penampilan lahir makhluk. Jika seseorang dapat melihat makhluk ciptaan sebagaimana aslinya, kebingungan atau pertentangan yang muncul dari peristiwa-peristiwa itu tidak akan menyebabkan kekecewaan atau keputusasaan. Dengan percaya kepada ruh Tuhan dan dengan membuatnya menguasai jiwa lahiriah, orang tidak hanya akan dibebaskan dari persoalan ketuhanan, tetapi akhirnya akan melampaui persoalan-persoalan Ketuhanan yang muncul pada dirinya. ${ }^{66}$

Karakteristik jalan sufi terdapat fakta bahwa semua guru sufi menjalankan secara beriringan aspek lahir dan batin (eksoteris dan esoteris) dan mampu menyelaraskan keduanya agar satu jalan dari kedua jalan tersebut melunturi jalan lainnya. Raga dan jiwa membentuk sebuah harmoni dengan tidak mengutamakan jiwa saja karena manusia hidup dalam keduniaan, dibutuhkan keseimbangan. Jika hidup dalam jiwa, manusia hanya akan hidup dalam utopia dan idealita. Fungsi jiwa adalah mentransformasikan materi. Oleh karena itu, manusia harus menginjakkan kaki di bumi dan tetap menatap tinggi di langit. Tujuan hidup adalah mencapai keseimbangan antara yang vertikal dan horisontal, antara duniawi dan ukhrawi. Ini merupakan salah satu karakteristik tasawuf. ${ }^{67}$

Jalan tasawuf adalah sebuah jalan aktif, yang artinya untuk menjadi ahli ibadah, seorang tafakur atau pencari Tuhan tidak perlu mengasingkan diri dari dunia kecuali untuk sementara untuk menjalani kontemplasi. Seseorang harus memenuhi kewajibannya terhadap masyarakat. Itu sebabnya tasawuf hanya mengajarkan bagaimana menjalani hidup sebagai manusia, menikah, memiliki anak, dan lain lain. Ajaran ini tidak menganjurkan pengasingan diri dan agar berperan dalam medan kehidupan.

\footnotetext{
${ }^{66}$ Elizabeth Sirriyyeh, Sufis anti Sufis (terj.) (Yogyakarta: Pustaka Sufi, 2003), hlm. 132.

${ }^{67}$ Jailani, hlm. 141-142.
} 
Oleh karena itu, dalam upayanya mencapai Tuhan, sufisme menekankan bahwa tauhid sebagai sesuatu yang prinsipil, yakni meyakini Allah sebagai Zat Yang Maha Esa, Maha Pertama, Maha Ada, Maha Hadir, Maha Mengetahui, Maha Berkuasa, dan Maha Hidup. ${ }^{68}$ Sementara itu, hakikat syahadat rasul adalah meyakini sepenuhnya bahwa Muhammad adalah penutup para nabi. AlQur'an adalah kitab Allah yang memelihara dan membenarkan informasi kitab-kitab sebelumnya. Artinya, Al-Qur'an adalah saksi atas kebenaran kitab sebelumnya. ${ }^{69}$

Dalam hubungan antara prinsip-prinsip tasawuf yang menekankan tujuan akhir untuk mencapai makrifat kepada Allah dengan prinsip-prinsip etika Islam, perlu untuk memahami dengan baik tentang hubungan etika dan usaha-usaha kaum sufi dalam mendekati Tuhan. Persepsi etika tentang Tuhan pada awalnya berkembang di kalangan kaum asketik (zuhhad), yang merupakan perkembangan awal tasawuf. Pandangan tentang Tuhan tidak hanya terbatas sebagaimana pandangan kaum teolog, karena memosisikan Tuhan sebagai sumber kebaikan, keindahan, dan segala yang ada, sehingga antara Tuhan dan manusia ada relasi komunikasi etik yang bersifat timbal balik. ${ }^{70}$

Mengingat dalam tasawuf, etika merupakan salah satu pilar dasar komunikasi manusia dengan Tuhan, maka etika bagi sebagian sufi merupakan tujuan utama dalam mengidentifikasi diri dengan sifat ketuhanan (ittasif bisifatillah) dan takhallaqu biakhlaqillah. Kaum sufi berpendapat bahwa satu-satunya jalan yang dapat mengantarkan seseorang untuk mengidentifikasikan

${ }^{68}$ Ibid., hlm. 142.

${ }^{69}$ Banani, Amin dkk., Poetry and Mysticism in Islam, the Heritage of Rumi (terj.) (Surabaya: Risalah Gusti, 2001), hlm.188-189.

${ }^{70}$ Khaled Bentounes, Le Soufisme Coeur de L'Islam (terj.) (Yogyakarta: Pustaka Sufi, 2003), hlm. 36. 


\section{Basis Pemikiran Etika Religius Syaikh Yusuf}

dirinya dengan sifat-sifat ketuhanan adalah melalui penyucian jiwa yang diawali dengan membentuk pribadi yang bermoral dan bersifat spiritual. Bertolak dari falsafah hidup ini, penilaian baik dan buruk serta sikap mental seseorang dinilai atas dasar pandangannya terhadap kehidupan duniawi dan komitmennya dengan nilai-nilai etis yang dipraktikkan dalam kehidupan.

Kenikmatan hidup duniawi menurut kaum sufi bukanlah tujuan, melainkan sarana. Oleh karena itu, dalam rangka pendidikan mental dan moral, yang utama adalah dengan cara menguasai atau menghilangkan penyebab utamanya, yaitu hawa nafsu. Dalam persepsi sufi, hawa nafsu merupakan pokok timbulnya kejahatan moral. Tidak terkontrolnya hawa nafsu yang cenderung pada kenikmatan duniawi akan menimbulkan kerusakan etika atau moral seperti munculnya fitnah, kesombongan, ria, takabur, dan perilaku-perilaku lainnya. Hal ini yang menjadi kendala bagi relasi manusia dengan Tuhannya. Untuk merehabilitasi sikap mental yang tidak baik, terapinya tidak cukup hanya menyentuh aspek lahiriah saja. Tetapi, perlu transformasi akhlak melalui amalan dan latihan kerohanian yang kuat (riyadah dan mujahadat). Tujuannya adalah untuk mengendalikan hawa nafsu serta menekannya sampai titik terendah bahkan mematikannya sama sekali. ${ }^{71}$

Di kalangan sufi terdapat seperangkat moral yang harus dimiliki untuk menjalankan relasi etis dengan Tuhan, yaitu yang dikenal dengan maqamat dan ahwal. Menurut Imam Abu Nasr as-Sarraj al-Tusi (w. $988 \mathrm{M}$ ), yang dimaksud dengan maqamat adalah tingkatan seorang hamba di hadapan Tuhan dalam hal ibadah, mujahadah, dan riyadah serta pemusatan diri kepada Allah. Ahwal adalah keadaaan yang mendominasi qalbu seseorang

\footnotetext{
${ }^{71}$ Al-Makki, Abu Thalib, Qu tul Qulub, Pasal ke-33, Dzikir Da'aim al Islam al Khams Allati Buniya Alaih (terj.) (Bandung: Mizan, 2005), hlm. 46.
} 
serta perasaannya yang terkandung di dalamnya. Jika maqamat adalah tingkatan moralitas seorang sufi untuk mencapai tujuan kepada Allah, maka ahwal merupakan pengalaman batin yang diperoleh seorang sufi dalam perjalanan rohanimua menuju tujuan tersebut. $7^{2}$

Upaya yang dapat dilakukan untuk menimbulkan rasa takut kepada Allah terkait makrifat adalah hati yang tenang, yaitu dengan mengingat Allah, baik secara terang-terangan atau sembunyisembunyi. Hal ini akan terjadi jika seseorang sudah merasa yakin bahwa Allah mampu melihat segala gerak-gerik dan keyakinan bahwa tidak ada sesuatu pun yang akan luput dari pengawasanNya, baik lahir maupun batin. Jika seseorang mampu memuliakan keadaan ini dan melaksanakannya dalam segala gerak-geriknya baik lahir maupun batin, maka ia akan terus-menerus khawatir karena merasa selalu diawasi oleh Allah. Seseorang yang selalu merasa diawasi Allah akan menjaga perilakunya karena khawatir melakukan sesuatu yang tidak diridhai-Nya. ${ }^{73}$

Oleh karena itu, batin manusia selalu sadar bahwa Allah Swt. senantiasa melihatnya dan menjauhkan dirinya dari segala perkara yang dibenci oleh Allah. Hati akan bersih dan penuh cahaya Ilahi. Pada saat itu, ia akan terus menjunjung tinggi perintah Allah dalam hatinya dan tidak mempedulikan orang lain dalam melaksanakan perintah Allah. Allah adalah tujuannya. ${ }^{74}$ Orang yang telah sampai kepada Allah, ia akan memiliki etika karena selalu merasa dekat dengan Allah, sehingga akan mempunyai sifat wara', zuhud, ikhlas, sabar, tawakal, yakin, cinta, rindu, dan akhlak terpuji lainnya dalam berhubungan dengan Allah dan makhluk hidup lainnya.

\footnotetext{
72 Ibid., hlm. 18.

${ }^{73}$ Masyharuddin, hlm. 113-114.

${ }^{74}$ Ibid., hlm.114-115
} 


\section{Basis Pemikiran Etika Religius Syaikh Yusuf}

Seluruh sifat ini telah meresap dalam tabiat dan terpendam dalam rahasia batin, tidak mengenali sifat-sifat lainnya sebab semua sifat mulia ini dianggap sebagai kebiasaan. Kaum sufi telah mengharuskan dirinya untuk menyifati semua sifat yang mulia tersebut serta mengamalkannya dengan baik sehingga menjadi kebiasaan diri, serta tidak pernah jenuh dalam menjalankan ibadah kepada Tuhan. ${ }^{75}$

Etika dan sikap terhadap dunia yang selanjutnya dikembangkan oleh seseorang yang ingin mencapai Tuhan adalah sikap alienasi atau pengasingan diri, yaitu menjauhakn diri secara batin dari hawa nafsu, hasrat, keinginan terhadap dunia, selanjutnya disertai oleh sikap pelepasan diri dari yang bersifat eksternal. Secara fisik, pelepasan ini adalah pelepasan sementara dari orangorang dan tempat yang akan membawanya pada kesesatan. Kesempuraan jiwa yang diperoleh dari pengasingan diri dan jalan spiritual tidak akan terikat oleh dan tidak juga tunduk pada jebakan-jebakan eksternal duniawi, serta menjadi tangguh dengan rintangan dan cobaan yang harus dihadapi dengan kesabaran dan ketabahan, sedangkan dunia ini dapat dimanja oleh kesenangan dan kelimpahan materi yang tersedia baginya. ${ }^{76}$ (Awn, 2007: 116).

Seorang sufi, Yahya bin Muadz, memberikan nasehat kepada orang-orang yang ingin menapaki jalan spiritual untuk fokus mencintai dan mengerahkan seluruh daya upaya untuk mencapai Allah dan tidak terlena pada bujukan iblis. Dunia seyogyanya hanya menjadi alat untuk mencapai akhirat dan bukan menjadi tujuan. Selain sangat dipengaruhi oleh keberhasilan wali-wali Allah, orang awam pada umumnya diajak untuk mengharap bahwa dalam kenyataannya seseorang mampu secara bertahap untuk

\footnotetext{
75 Ibid.

${ }^{76}$ Al-Karraz, Abu Said, Al Tariq Ailallah atau Kitab as Sidq (terj.) (Yogyakarta: Pustaka Sufi, 2003), hlm. 60.
} 
mengendalikan kesenangannya bahkan mencapai suatu titik fana, atau peleburan dari segala sesuatu yang bukan Allah.

Sehubungan dengan makrifat, alienasi diri para sufi merupakan suatu usaha pelepasan secara radikal dari segala hal yang dapat menghalangi dan merintangi perkembangan spiriritual diri. Dengan demikian diharapkan usaha-usaha spiritual melalui pelaksanaan syari'at dan tarekat dapat mencapai hakikat dan makrifat, sebab dinding tebal yang tidak dapat ditembus oleh iblis yang selalu menggoda manusia.

Sebagai kesimpulan, seluruh etika Islam yang bercorak tasawuf, tulus kepada Allah, berbuat baik terhadap sesama, maka disebut sufi. Ketulusan kepada Allah berarti menghilangkan kepentingan-kepentingan diri untuk melaksanakan perintahperintah Allah. Demikian juga, pergaulan yang baik dengan sesama manusia, selama itu sesuai dengan syari'at. Setiap orang yang menyimpang dari syari'at atau mengingkarinya, maka dia bukanlah sufi; jika mengaku sufi, berarti dia telah berdusta. ${ }^{77}$

Ibnu Arabi dan al-Hallaj menyebut penyatuan dengan Tuhan (wahdat al-wujud) pada hakikatnya merupakan etika tertinggi seorang hamba yang merasa bahwa wujudnya sebenarnya tidak ada. Wujud yang ada pada hakikatnya adalah wujud Tuhan yang termanifestasi dalam ciptaan-Nya. Bagi kaum awam dan ahli fiqh yang tidak mengenal tasawuf secara mendalam dan belum mencapai makrifat, pandangan seperti ini dianggap sesat dan kafir. Bagi orang yang mencapai tingkatan makrifat, pandangan ini justru merupakan etika tertinggi kepada Tuhan, karena dalam pandangan itu terkandung makna kelemahan dan ketidakberdayaan hamba di hadapan Tuhannya. Oleh karena itu, etika keagamaan dalam kaitannya dengan hubungan manusia dan Tuhan terbagi dua, yaitu

77 Ibid., hlm. 60. 


\section{Basis Pemikiran Etika Religius Syaikh Yusuf}

etika orang-orang awam yang memahami agama dari kulit luarnya dan etika orang yang telah mencapai makrifat.

Pemahaman tentang syari'at, tarekat, hakikat, dan makrifat yang diuraikan Syaikh Yusuf dalam karya-karyanya, merupakan ciri dan corak etika Syaikh Yusuf. Etika ini merujuk pada karyakarya sufi terdahulu, dengan berlandaskan Al-Qur-an dan sunnah serta pandangan ulama-ulama sufi yang hakiki terdahulu, yaitu ulama-ulama yang memahami syari'at lahir dan batin serta mengamalkannya dalam kehidupan sehari-hari. Hal penting yang perlu dicatat dalam karya-karya Syaikh Yusuf adalah pengulangan yang sering terjadi. Artinya, seringkali Syaikh Yusuf mengulangulang pembahasan. Jadi tidak mengherankan bila pembahasan di dalam satu karya kemudian dapat dijumpai lagi pada tulisan atau karya yang lainnya. Hal itu barangkali dimaksudkan agar muridmuridnya memiliki pemahaman yang mendalam.

Akhirnya, konsep-konsep kunci etika sufisme Syaikh Yusuf, seperti yang diuraikan di atas, merupakan inti dari dakwah Islam dari masa ke masa. Oleh karena itu, siapa pun yang melakukan dakwah Islam seharusnya memiliki pandangan yang mendalam dan luas mengenai konsep-konsep tersebut di atas. Pandangan yang mendalam tersebut tentunya didasarkan pada sumbersumber literatur Islam. Dengan demikian diharapkan dakwah yang dijalani merupakan cerminan dari pesan inti Islam, yaitu menjadi rahmat bagi semesta alam. 



\section{Bab IV \\ UNIVERSALISME PESAN ETIS DALAM KARYA SYAIKH YUSUF}

Etika religius Syaikh Yusuf merupakan etika yang memiliki landasan normatif yang bersumber pada keyakinan dan pengalaman keberagamaan. Etika ini menitikberatkan pada dimensi relasi dan harmonisasi kehidupan manusia dengan Sang Pencipta berdasarkan suatu pandangan universal dan rasional. Hubungan ini sangat signifikan, karena sebagai makhluk yang lemah, manusia selalu resah dan memiliki ketergantungan kepada yang lebih kuat dan perkasa. Ketergantungan ini terkait dengan tindakan dan sikap manusia tentang yang baik dan buruk, serta dengan kebahagiaan hidup di dunia dan di akhirat.

Bagi penganut pandangan filsafat etika an sich tanpa agama, yang terpenting adalah melakukan tindakan baik yang secara umum diakui oleh masyarakat: tindakan itu baik dan mendatangkan kebaikan bagi diri sendiri dan orang lain. Sementara itu, dimensi hidup setelah mati tidak berkaitan dengan Tuhan. Kebahagiaan dalam pandangan filsafat etika seperti ini adalah memberi kebahagiaan bagi diri sendiri dan orang lain melalui tindakan yang benar dan etis. 


\section{A. Pesan Ilahi dalam Teks Keagamaan dan Universalisme Islam dalam Karya-karya Syaikh Yusuf}

Ajaran pokok tarekat Syaikh Yusuf, berkisar pada usaha manusia untuk mendekatkan diri kepada Allah Swt., mengacu pada peningkatan kualitas akhlak yang mulia serta penekanan amal saleh dan dzikir. Ibadah shalat dan dzikir merupakan amalan yang dapat membawa salik (hamba) sampai ke ujung suluknya. Kedudukan dzikir dalam tarekat Syaikh Yusuf menempati posisi yang sangat penting. ${ }^{1}$ Ini adalah salah satu amalan untuk mencapai kebahagiaan sempurna bagi seorang hamba untuk dapat mencapai Tuhannya.

Seperti halnya sufi-sufi lain, Syaikh Yusuf mengatakan bahwa tujuan utama dari perjalanan hamba dalam suluknya adalah untuk bertemu dengan Tuhan. Ada tiga jalan yang biasa ditempuh untuk sampai kepada Tuhan, yaitu: pertama, jalan orang kebanyakan, yaitu dengan memperbanyak amal-amal lahir seperti shalat, puasa, haji, zakat, jihad, dan lain lain. Kedua, jalan ahlu al-mujahadah, yaitu jalan orang-orang yang lebih mementingkan amalan-amalan batin melalui latihan-latihan keras, misalnya menghilangkan akhlak buruk dan menggantinya dengan akhlak baik, membersihkan jiwa, menyucikan hati, mengosongkan roh, dan lain-lain. Ketiga, jalan ahlu az-dzikr dan ahlu al-muhabbah kepada Allah secara dzahir dan batin. Kelompok ini menyejajarkan amalan dzahir dan amalan batin. ${ }^{1}$

Di antara ketiga jalan tersebut, yang terbaik adalah jalan yang ketiga. Pokok-pokok amalan yang harus ditempuh dan dilalui untuk sampai kepada Tuhan menurut jalan ini adalah taubat kepada Tuhan dari segala dosa lahir dan batin, zuhud dari dunia, tawakal kepada Allah, qana'ah terhadap pemberian Tuhan, ber'uzlah dari sesama makhluk, khususnya manusia dengan menghilangkan kecenderungan hati yang berlebihan, memastikan tawajuh kepada Allah dengan segala rahasianya, sabar terhadap segala cobaan melalui mujahadatun al-

1 Ensiklopedi Islam, hlm. 217. 


\section{Pesan Dakwah dan Etika Religius Dakwah dalam Karya Syaikh Yusuf}

nafsih, ridha kepada qada Allah dengan menyerahkan segala urusan kepada-Nya dan memasrahkan diri ke hariabaan-Nya, melakukan dzikir secara lahir dan batin, benar-benar dalam pendekatan kepada Allah. ${ }^{2}$ (Yusuf, Al-Nafhat al-Saylaniyah, dalam Tudjimah).

Sejalan dengan pandangan Syaikh Yusuf di atas, seorang sufi Islam yang juga ahli etika Ibnu Miskawih mengatakan bahwa kebahagiaan yang sempurna tidak mungkin tercapai, kecuali telah menguasai seluruh bagian filsafat. Untuk itu, dalam menggunakan akal sebagai karunia tertinggi Tuhan, seorang hamba harus mendekatkan diri kepada Tuhan dengan etika yang baik dan sempurna. Beretika dengan baik merupakan suatu syarat untuk dapat hidup sehat secara jasmani dan rohani, karena etika dipandang ilmuwan muslim sebagai pengobatan rohani. Hal ini seperti tercermin dalam sebuah kitab etika, dari Abu Bakr al-Razi, (w.925), seorang ahli klinis muslim, yang berjudul al-Thibb alRuhani atau Kedokteran Rohani. Para ilmuwan muslim memang mensejajarkan etika dengan kedokteran, baik dari segi kepentingannya maupun metodenya. ${ }^{3}$

Jiwa seseorang akan menjadi mulia dengan berperilaku baik kepada Tuhan dan manusia. Jiwa yang mulia adalah jiwa yang terjaga dari kehinaan, kerendahan, dan ketamakan. Berbeda halnya dengan kesombongan yang timbul dari kebanggaan atas diri dan penghinaan terhadap orang lain, dua anggapan ini yang kemudian memicu timbulnya kesombongan. Sementara sikap baik dan jiwa mulia lahir dari budi pekerti yang mulia, yaitu kemuliaan jiwa dan penghormatan atau pengagungan terhadap Tuhan, sehingga sebagai seorang hamba, ia merasa hina dan rendah, yang kemudian melahirkan dua pekerti mulia yaitu, kemuliaan jiwa dan keter-

2 Cawidu, Harifuddin, "Peringatan 300 tahun Mendaratnya Syeikh Yusuf AlKhlwaty AIMakassary di Afrika Selatan", Makalah Seminar Nasional, Ujung pandang: Universitas Hasanuddin, 1994, hlm. 7.

3 Ibid. 
peliharaannya. Sumber dari semua ini adalah persiapan jiwa dan pertolongan Tuhan. Tanpa pertolongan Tuhan, maka tidak akan ada kebaikan sama sekali.

Selanjutnya, pembahasan tentang pesan universal Islam, perlu memahami isi kandungan teks yang seringkali bercampur antara akhlak dan ajaran-ajaran fiqh serta tasawuf. Memilih ajaran yang universal dari teks naskah Syaikh Yusuf, seringkali ditemukan di satu paragraf atau dari suatu naskah merupakan intisari dari pesan-pesan universalnya. Dapat dikatakan bahwa hampir seluruh tulisan Syaikh Yusuf menekankan pentingnya pelaksanaan syari'at dalam pengertian yang luas dan juga pelaksanaan fiqh dan tasawuf. ${ }^{4}$ Fiqh dan tasawuf dalam pengertian universal merupakan aspek lahir dan batin dari setiap agama. Fiqh mewakili aspek lahiriah dari ketentuan-ketentuan ajaran agama, dan tasawuf mewakili aspek batin. Setiap agama memiliki kedua aspek ini, meskipun menggunakan istilah yang berbeda. Inilah yang dimaksud dengan aspek universal yang sering diungkapkan secara berulang-ulang oleh Syaikh Yusuf.

Pada umumnya, seluruh teks karya Syaikh Yusuf merupakan tulisan-tulisan pendek yang seringkali berulang. Namun demikian, tidak berarti hal itu tidak penting. Mungkin sebagaimana tradisi penulisan Islam pada saat itu, yang dimaksudkan agar tidak lupa terhadap ajaran-ajaran Islam. Teks terpenting dari karya Syaikh Yusuf yang mengandung ajaran-ajaran universal adalah Bidayat al-Mubtadi, yang menerangkan tentang Tuhan Yang Maha Satu atau Tunggal, yang berkuasa atas segala sesuatu. ${ }^{5}$ Bagian penting dari naskah tersebut dapat dilihat sebagai berikut:

4 Kartanegara, Mulyadhi, Nalar Religius, Memahami Hakikat Tuhan, Alam, dan Manusia (Jakarta: Penerbit Erlangga, 2007), hlm. 48.

5 Darusman, Lukmanul Hakim, "Jihad in Two Faces of Syariah, Case Studies of Syaikh Yusuf Al-Maqassary and Syaikh Daud al Fatani", Disertasi (Canberra, Australia: ANU, The Australian, 2008), hlm. 5. 


\section{Pesan Dakwah dan Etika Religius Dakwah dalam Karya Syaikh Yusuf}

Adapun pengetahuan mengenai Allah Ta'ala itu, supaya hamba mengetahui bahwa Allah Ta'ala mempunyai sifat-sifat yang sempurna, Tuhan itu pencipta semesta alam, semua yang maujud, zatnya, sifatnya pekerjaannya yang baik dan buruk, semua di bawah kekuasaan-Nya dan kehendak-Nya. Adapun mengenai kepercayaan kepada Hak Ta'ala adalah sebagai berikut: Sesungguhnya Tuhan itu Laysa kamitslihi Syai'un". Allah itu satu, tak ada teman dalam zat-Nya, sifatNya, dan af'alNya (perbuatan-Nya). Tuhan berbeda dengan semua yang dikhayalkan dalam pikiran manusia. ${ }^{6}$

Pandangan di atas menunjukkan bahwa ide tentang keabsolutan Tuhan merupakan ide universal tentang Tuhan. Setiap agama memiliki pandangan bahwa Tuhan adalah Maha Sempurna dan memiliki segala sifat dan karakter yang sempurna, memiliki kehendak absolut yang tidak dapat ditentang, serta pencipta alam semesta. Segala yang ada di alam ini tunduk pada kekuasaan-Nya. Dialah Yang Maha Kuasa atas segala sesuatu dan segala makhluk di alam ini karena semesta diciptakan oleh-Nya. Ajaran Syaikh Yusuf tentang keharusan universal setiap hamba beriman kepada Tuhan, mengetahui sifat kesempurnaan Tuhan, merupakan ajaran yang juga terdapat di dalam masing-masing agama.

Dalam Al-Nafhat al-Sailaniyya, Syaikh Yusuf menjelaskan tentang syarat seorang salik yang sedang menuju jalan Tuhan.

Seorang salik harus memiliki adab atau etika yang baik terhadap semua makhluk, karena semua makhluk adalah mazahir (cerminan) nama-nama Allah dan sifat-sifat-Nya. Etika yang baik terhadap semua makhluk diharuskan bagi orang yang arif billah (orang yang mengenal Allah). Etika kepada Allah Ta'ala merupakan hal utama. sabda Nabi: "Tuhan mengajarkan etika kepadaku maka aku belajar baik-baik." Di antara adab (etika) yang baik terhadap Allah itu seperti dikatakan oleh Ibnu 'Athaillah al-Syadhili al-Iskandari (seorang sufi dari Iskandaria Mesir): “Perkara itu bukanlah adanya pencarian, tetapi supaya engkau beradab (beretika) baik, yaitu seorang hamba mencari sesuatu dari

6 Tudjimah, Syaikh Yusuf Makasar, Riwayat dan Ajarannya (Jakarta: UI Press, 1997), hlm. 52 . 


\section{Agama dan Bayang-Bayang Etis Syaikh Yusuf Al-Makassari}

kekayaan Tuhannya dan tidak diminta yang lain: jangan mengira bahwa Allah akan memberi apa yang harus kerjakan sebagai Tuhan, bagi orang ahli Allah, itu perkara Tuhan, dalam perkara hamba beradab (beretika) di depan Tuhannya dengan adab (etika) yang baik dan menyerahkan semua perkara kepada Allah, maka Allah rela kepadanya. la tak meminta sesuatu, jika la minta, ini hanya haknya hamba saja. Maka salik (orang yang menuju Tuhan) harus baik adab (etikanya) kepada Allah dalam segala hal dan rahasianya." ${ }^{\text {7 }}$

Seorang salik juga harus berprasangka baik terhadap manusia. Semua ini membawa sangkaan baik terhadap Tuhan dengan bersandarkan firman Allah: "Pada-Nya kunci yang gaib, tak ada yang tahu kecuali Dia. Wahai hamba-Ku, jangan menolak rahmat Allah". ${ }^{8}$

Syaikh Yusuf menekankan pentingnya etika yang baik tidak hanya kepada Tuhan, tetapi kepada seluruh makhluk tanpa memandang suku, agama, ras atau golongan. Bahkan seseorang yang sedang menuju Tuhan sekalipun, diharuskan memiliki etika yang luhur dan mulia. Siapa pun yang belum memiliki etika religius, tidak akan sampai pada derajat mengenal Tuhan, atau ia tidak dapat menjadi orang yang benar-benar saleh. Ini berarti bahwa Islam tidak pernah memisahkan etika kepada Tuhan dan manusia. Etika seperti dua sisi mata uang. Seseorang tidak dapat memperhatikan etika kepada Tuhan dan mengabaikan etika kepada makhluk-Nya, atau sebaliknya. Etika religius Syaikh Yusuf, yang berlandaskan ajaran Islam ini, menekankan harmonisasi antara kehidupan dunia dan akhirat, sebagaimana pandangan Soren Kierkegaard, bahwa manusia dapat menjadi hamba Tuhan yang saleh sekaligus juga menjadi anggota masyarakat yang aktif dan baik.

Dalam Sirr al-Asrar, Syaikh Yusuf mengingatkan kepada salik dengan mengatakan:

Seorang salik harus tahu bahwa Allah itu bersamanya di mana pun ia berada karena la berfirman, wahuwa maakum ainama kuntum

\footnotetext{
7 Ibid., hlm. 26.

8 Ibid., hlm. 45.
} 


\section{Pesan Dakwah dan Etika Religius Dakwah dalam Karya Syaikh Yusuf}

(la bersamamu di mana pun kamu berada). Sabda Nabi: "Iman yang terbaik bagi seorang hamba adalah ia mengetahui bahwa Allah bersama dia di manapun ia berada". ${ }^{9}$

Kalimat wahuwa maakum ainama kuntum menunjukkan bahwa Tuhan mengawasi sikap dan perbuatan manusia. Oleh karena itu, dalam melaksanakan setiap perbuatan seseorang haruslah mengingat dan sadar bahwa Tuhan mengawasi dan hadir di setiap tempat (omni present). Dan setiap perbuatan akan dimintai pertanggungjawabannya. Etika religius ini tidak hanya terdapat di dalam, tetapi juga di dalam ajaran agama-agama lain.

Karya Syaikh Yusuf yang lain juga menunjukkan konstruksi ajaran Islam yang bercorak tasawuf dan tarekat, seperti bagaimana seseorang menjadi manusia sempurna (insan kamil), yaitu dalam pengertian menjadi waliyullah. Hal ini tentu saja tidak dapat dimasukkan ke dalam kategori universalisme. Konsep insan kamil (waliyullah) merupakan ciri khas yang hanya terdapat di dalam ajaran Islam.

Syaikh Yusuf adalah seorang ulama yang memahami tasawuf dengan baik. Imajinasi dan amalan tasawufnya tidak hanya bersumber dari hadits biasa, tetapi juga dari hadits qudsi. Amalanamalan sufi terdiri dari dua macam: ritus-ritus yang diwajibkan kepada muslim yang bersifat sukarela dan yang sunnah. ${ }^{10}$ (Lings, 1993: 96).

Pujian kepada Allah merupakan amalan-amalan para sufi. Pujian ini merupakan hal yang penting, meskpun terdapat kontradiksi sehubungan dengan amalan kewajiban fardu dengan amalan yang bersifat sukarela, misalnya dengan adanya ayat AlQur'an, bahwa dzikrullah yang bersifat sunah lebih bernilai

\footnotetext{
9 Ibid., hlm. 46.

${ }^{10}$ Yusuf, dalam Tudjimah, 1997, hlm. 68 dan Naskah Bundel A. hlm. 101.
} 
daripada shalat yang sifatnya fardu. Namun, keteladanan para sufi telah memperlihatkan amalan sunah sebagai amalan yang mengandung keteladanan potensial, karena sanggup merangkul dan menembus kehidupan seutuhnya. Kemampuan inilah yang diusahakan tercapai dan mengamalkan puji-pujian itu secara metodik. Makna hadits qudsi yang sering menjadi spirit bahwa kewajiban legal tidak dapat digantikan oleh perbuatan atau amalan yang bukan wajib, menjadi perdebatan.

Salah satu amalan yang dilakukan para sufi, termasuk yang sering dilakukan Syaikh Yusuf adalah meditasi serta dzikir sebagaimana tertuang dalam karyanya tentang dzikir yang telah disebutkan di muka. Landasan dari hal ini adalah karena Al-Qur'an terus-menerus menandaskan pentingnya meditasi, yang mana fungsi kontemplasi dan dzikir dalam kehidupan spiritual bagaikan fungsi darah beserta urat-uratnya dalam kehidupan jasmani; tafakur mempengaruhi jiwa dengan doanya untuk membuka saluran-saluran jasmani dan rohani secara alamiah. Hasil yang diraih dari praktik amalan ini adalah transformasi batiniah, meneguhkan kebenaran-kebenaran metafisika atau eskatologis. Jalan ini merupakan penghubung antara kemunafikan natural menuju keikhlasan spritual.

Tanpa dzikir, jasmani tidak akan memberikan manfaat apaapa. Tafakur mempengaruhi jiwa dengan doanya untuk membuka saluran-saluran jasmani dan rohani secara alamiah. Hasil yang diraih dari praktik amalan ini adalah transformasi batiniah atau imajinasi atau alam bawah sadar, serta pencapaian yang selaras dengan realitas aktual. Hal ini sangat baik untuk inteligensia guna meneguhkan kebenaran-kebenaran metafisika atau eskatologis. Imajinasi atau alam bawah sadar harus diorientasikan percaya dengan sungguh-sungguh akan dunia ini, bukan kepada Tuhan atau dunia yang akan datang semata. Karena pada dasarnya manusia secara a priori senantiasa mengalami kemunafikan yang tidak disadari. Oleh karena itu, jalan ini merupakan penghubung antara kemunafikan natural menuju keikhlasan spritual. 


\section{Pesan Dakwah dan Etika Religius Dakwah dalam Karya Syaikh Yusuf}

Amalan-amalan tasawuf memiliki keberagaman, dengan tujuan dapat menjangkau keberagaman serta kepelikan jiwa manusia yang setiap unsurnya memiliki misteri sendiri, sehingga harus diisi dengan cahaya amalan keikhlasan dalam segala aspeknya (Lings, 1993: 115). Sejalan dengan pandangan ini, ada juga pandangan bahwa pesan Tuhan dalam amalan tasawuf dapat dicapai dengan pengungkapan rasa teofatik yang menyatakan secara tidak langsung hubungan antara keadaan spiritual Tuhan (Ernst, 2003: 274).

Dalam kaitannya dengan pesan Tuhan yang digali dari pemahaman Islam lewat sufisme, perlu diperhatikan bahwa sufisme ditandai oleh tiga hal: Pertama, berusaha menjadikan iman yang bersifat nalar menjadi perasaan yang bergelora, mengubah iman aqli menjadi iman qalbi. Kedua, melatih dan mengembangkan diri menuju tingkat kesempurnaan dengan cara mengumpulkan sifat-sifat mulia dan membersihkan diri dari sifat-sifat tercela, dan ketiga, memandang dunia ini hanya sebagian kecil dari kehidupan luas hingga ke masa akhir kehidupan dunia.

Al-Ghazali, seorang sufi yang sering disebut oleh Syaikh Yusuf dalam karyanya, menyebutkan definisi sufisme dari beberapa tokoh tasawuf yang hampir secara seragam, yaitu bahwa sufisme ditegakkan di atas Al-Qur'an dan Sunah. Dengan demikian, dapat disimpulkan bahwa nilai-nilai sufisme adalah nilai-nilai Islam. ${ }^{11}$

Zuhud merupakan aspek praktis tasawuf yang pada masa awalnya tidak terlepas dari permasalahan-permasalahan yang dihadapi. Ia tampil dalam rangka memberikan solusi spiritual terhadap problematika sosial, politik, ekonomi, dan budaya. Zuhud bukanlah asketisme dalam pengertian keadaan atau corak kehidupan orang-orang yang menolak masalah-masalah duniawi

11 Yusuf, dalam Tudjimah, 1997, hlm. 67. 
atau madzhab pemikiran yang meletakkan semua tekanan pada segi-segi rohani dan sepenuhnya mengabaikan segi-segi kehidupan duniawi. Zuhud adalah asketisme dalam pengertian kehidupan sederhana, berdasarkan motif keagamaan. ${ }^{12}$

Zuhud adalah meninggalkan hal-hal yang berlebihan walaupun halal, menunjukkan sikap hemat, hidup sederhana dan menghindari keberlebihan, kemewahan, atau pemilikan harta yang lebih, yang lebih berarti konsumtif ketimbang produktif. Zuhud dalam pengertian di atas juga mendorong untuk mengubah harta bukan hanya sebagai aset yang bernilai ekonomis, melainkan juga sebagai aset yang bernilai sosial.

Konsep penting yang dapat diperhatikan dari zuhud adalah sebagai solusi spiritual terhadap problematika sosial. Zuhud bukanlah asketisme; zuhud merupakan kehidupan sederhana berdasarkan motif keagamaan. Zuhud bermakna meninggalkan hal-hal yang berlebihan walaupun halal, sikap mengubah aset yang bernilai ekonomis sekaligus bernilai sosial.

Konsep-konsep etika Syaikh Yusuf secara substantif berbasis pada prinsip al-takhalluq bi akhlaq Allah (berakhlak dengan akhlak Allah). Konsep ini mengandung arti bahwa seseorang harus berusaha mencontoh dan menerapkan dalam dirinya semua sifat Tuhan (al-Asma al-Husna), kecuali sifat kibr (kesombongan, kebanggaan) yang menjadi hak Allah semata. Melalui jalan ini seseorang akan mencapai kesucian moral lahir dan batin.

Etika Syaikh Yusuf bersifat komprehensif, substantif, dan universal. Syaikh Yusuf sendiri berkali-kali menekankan perlunya menerapkan husnul khuluk (akhlak luhur), baik terhadap Tuhan maupun makhluk. Akhlak yang baik atau luhur haruslah bersifat utuh dan lengkap serta tercermin dalam seluruh penampilan

${ }^{12}$ Syukur, HM. Amin, Muhayya, Abdul, (ed.), Tasawwuf dan Krisis (Semarang:

Pustaka Pelajar dan IAIN Walisongo, 2001), hlm. 87-88. 
seseorang, yang mencakup sikap, sifat, perkataan, dan perilaku yang timbul dari hati yang bersih.

Koherensi dan konsistensi antara hati, sikap, sifat, perkataan, dan perilaku akan membentuk pribadi yang bermoral luhur, yang memiliki sifat-sifat kejujuran, kebenaran, kasih sayang, kesederhanaan, dan sebagainya. Husnul khuluk kepada makhluk Allah harus dibarengi dengan husnul adab (adab kesopanan). Husnul khuluk kepada Allah mengandung arti tetap konsisten dalam menjalankan perintah Allah, menjauhi larangan-Nya, tetap berzikir kepada-Nya. Sedangkan husnul adab mengandung arti memperbaiki sikap dan perilaku.

Husnul khuluk dan husnul adab kepada Tuhan akan melahirkan pribadi yang tangguh, optimis dalam hidup, tidak kenal putus asa, karena yakin akan sifat rahman dan rahim Allah. Husnul khuluk kepada sesama makhluk mengandung makna yang sangat dalam karena timbul dari rasa kemakhlukan yang tinggi, dan bukan sekadar solidaritas kemanusiaan saja. Rasa kemahklukan ini berangkat dari kesadaran bahwa apa pun yang ada di alam ini adalah makhluk Allah.

Moralitas luhur yang dapat dikembangkan dari rasa kemahklukan adalah tumbuhnya rasa kecintaan, rasa sayang, dan kepedulian terhadap lingkungan. Rasa kemakhlukan yang tinggi tentunya akan melahirkan rasa kemanusiaan yang luhur, sebab jangankan menyakiti manusia, menyakiti atau membunuh seekor semut pun patut dihindari. Inti dari etika religius Syaikh Yusuf adalah tercapainya kedudukan seorang hamba sebagai insan kamil. Manusia yang memiliki etika lahir dan batin akan menjadi cermin dari keagungan Allah. ${ }^{13}$ Etika ini dapat dikatakan sebagai etika yang bersifat humanis, teologis, dan kosmologis, karena ia

\footnotetext{
${ }^{13}$ Ibid., hlm. 92-93.
} 
mencakup ketiga dimensi tersebut sehingga pribadi seperti ini disebut insan kamil.

Konsep insan kamil melihat bahwa manusia adalah wujud yang utuh dan merupakan manifestasi Ilahi di dalam semesta. Manusia adalah citra Tuhan, dan kenyataannnya adalah mata rantai yang menghubungkanTuhan dan alam semesta. Manusia adalah tujuan utama yang ada di balik penciptaan alam semesta karena tiada ciptaan yang lain yang memiliki sifat-sifat untuk menjadi cermin Ilahi yang sesungguhnya. Menurut Muhammad Iqbal, konsep insan kamil adalah konsep yang di dalam diri sang mukmin terdapat kekuatan, wawasan, perbuatan, dan kebijaksanaan. Hal tersebut tercermin di dalam diri seorang nabi. ${ }^{14}$ Pandangan Iqbal tentang mukmin yang menjadi tuan bagi nasibnya sendiri dan secara bertahap dapat mencapai derajat kesempurnaan, dapat dikatakan sejalan dengan pandangan filosof Jerman, Kierkegaard, tentang filsafat eksistensialisme yang mengutamakan aktualisasi diri dalam masyarakat dengan tetap menjadi saleh. Artinya adalah menyatukan etika pada pencipta dan etika pada masyarakat dalam kehidupan sehari-hari. ${ }^{15}$

Secara keseluruhan, filsafat etika dalam Islam bersumber dari iman, yang merupakan syarat utama untuk mencapai kesempurnaan (insan kamil), yang tergambar jelas dalam konsepsi manusia sebagai khalifah di dunia. Manusia yang memiliki keabsahan menyandang tugas sebagai khalifah adalah manusia yang beriman, yang memandang alam dan seluruh isinya dengan optimistis dan memiliki tujuan-tujuan tertentu. Iman juga menerangi hati

${ }^{14}$ Effendi, Djohan, "Adam dan Insan Kamil: Pandangan Iqbal tentang Manusia", dalam Dawam Rahardjo, Insan Kamil, Konsepsi Manusia Menurut Islam, (Jakarta: Grafiti Pers, 1985), hlm. 24.

${ }^{15}$ Biddiss, Michael D, The Age of the Masses Ideas an Society in Europe Since 1870, (England: Penguin Books, 1977), hlm. 246. 
manusia dan membimbingnya ke arah kebenaran dan memberikan harapan bagi hasil-hasil dari suatu perbuatan yang baik. ${ }^{16}$

Pengaruh lain dari iman adalah memberikan kebahagiaan jiwa dan rohani dalam diri manusia. Kebahagiaan semacam ini diperoleh misalnya dari sifat murah hati dan suka menolong. Selain itu, iman juga berfungsi untuk memperbaiki hubunganhubungan sosial seperti saling menghargai hak dan peraturan serta pembatasan-pembatasan yang berlaku serta kepercayaan satu sama lain atas dasar nilai-nilai spiritual. Setiap individu memandang dirinya memiliki tanggung jawab dan kewajiban kepada masyarakatnya, memperlihatkan kebaikan dan ketulusan yang sama, baik dalam kehidupan pribadi maupun dalam kehidupan sosial. ${ }^{17}$

Pada akhirnya, iman memberikan bantuan dan kelapangan pada kesengsaraan dengan membentuk kekuatan dalam diri manusia untuk mengubah penderitaan menjadi kebahagiaan. Dengan iman pula ilmu pengetahuan digunakan sebagai alat yang bermanfaat bagi kemanusiaan, bukan sebaliknya, yaitu sebagai monster yang membahayakan kehidupan manusia. ${ }^{18}$ Menurut Muthahhari, iman adalah norma tertinggi atau etik tertinggi. ${ }^{19}$ Keimanan akan menjadi norma tertinggi, etik, atau kerangka orientasi bagi manusia dalam memberikan makna dan penilaian terhadap lingkungan alam, manusia, dan dirinya sendiri. ${ }^{20} \mathrm{Hal}$ ini selaras dengan karakter filsafat manusia itu sendiri, yaitu keseimbangan antara pikiran yang baik dan tubuh yang baik. Dari

\footnotetext{
${ }^{16}$ Hasan, Ahmad Rifai, "Manusia Serta Dimensi dalam Pandangan Mutahhari", dalam Dawam Rahardjo, Insan Kamil, hlm. 129.

17 Ibid.

18 Ibid.

${ }^{19}$ Ibid., hlm. 146.

${ }^{20}$ Ibid., hlm. 147.
} 
pikiran yang baik dan tubuh yang baik ini, manusia dapat menyeimbangkan kehidupan dan alam sekitarnya. ${ }^{21}$

Jadi, jiwa berpikir secara potensial dan apabila bentuk-bentuk dari pikiran tersebut di atas secara rasional bersatu dalam jiwa, maka jiwa dan akal itu sama, yaitu dalam pengertian telah menyatu dan harmonis dalam pikiran dan dorongan keinginan. Akal akan mengalihkan jiwa menjadi pelaku pemikiran yang aktual. ${ }^{22} \mathrm{Hal}$ ini sangat penting dalam kaitannya dengan pelaksanaan etika religius dalam kehidupan sehari-hari, karena sebagaimana pandangan filosof Islam, Ibnu Sina, bahwa kekuatan yang pasti adalah kekuatan intelek akal, ${ }^{23}$ karena akal yang mendorong pemahaman tentang tiga hal penting dalam kepastian filsafat, yaitu metafisika, fisik, dan moral atau kepastian etika. ${ }^{24}$ Artinya, akal memiliki peranan yang penting dalam proses filsafat yang tidak hanya berkaitan dengan kehidupan duniawi, tetapi juga ukhrawi. Dalam etika religius, yaitu tanggung jawab dari suatu tindakan tidak hanya berhenti pada tanggung jawabnya di dunia, tetapi juga di akhirat. Dengan kata lain, etika yang dilakukan di dunia memiliki tanggung jawabnya di dunia dan di akhirat.

Oleh karena itu, sufisme yang seringkali menekankan pentingnya etika religius dalam segala aspek kehidupan manusia, memiliki kaitan yang erat dengan filsafat. Jika sufisme adalah suatu pengalaman yang digambarkan dalam tindakan untuk menjelaskan kondisi psikologi manusia tentang apa yang dirasakan dalam kaitannya dengan pengalaman ketuhanan, maka pandangan-

${ }^{21}$ Bacon, Francis, The Advancement of Learning (Heron Books, 1861), hlm. 178.

${ }^{22}$ Abu Riddah, M. Abdu al Hadi, "Razail al Kindi al Falsafiyyah, Dar al-Fikr al Arabi", dalam Nurcholis Madjid, Khazanah Intelektual Islam, (Bandung: Bulan Bintang, 1997), hlm. 97.

${ }^{23}$ Ibid., hlm. 127.

${ }^{24}$ Fleming,S.J, T.V, Foundations of Philosophy (Sydney: The Shakespeare Head, 1949), hlm. 129. 
pandangan filosofis memiliki akar dari kondisi-kondisi psikologis manusia. ${ }^{25}$ Pada dasarnya, agama merupakan sesuatu yang misterius, sesuatu yang secara pasti tidak dapat dibuktikannya saat ini. Ia hanya diyakini dengan keimanan dan bukti-bukti nalar. Inilah sebenarnya inti dari keseluruhan agama, yaitu menyadarkan bahwa ada sesuatu yang tidak dapat dibuktikan secara langsung di dunia ini, karena berkaitan dengan hal-hal yang misterius bagi manusia, yaitu alam metafisika yang hanya dapat dijangkau dengan keimanan atau kepercayaan. ${ }^{26}$

\section{B. Etika Religius Syaikh Yusuf dalam Dakwah}

Konsep al-takhalluq bi akhlaq Allah (berakhlak dengan akhlak Allah) mengandung arti bahwa seseorang harus berusaha mencontoh dan mempraktikkan sifat-sifat Tuhan (al-asma alhusna), kecuali sifat kibr (kesombongan). Melalui jalan ini seseorang akan mencapai kesucian moral lahir dan batin. Hal ini penting dalam melaksanakan dakwah Islam, karena dari basis nilai seperti inilah metode dakwah Syaikh Yusuf diterima dan berkembang. Metode dakwah Syaikh Yusuf sangat adaptif dalam mengembangkan ajaran-ajaran Islam sesuai dengan kondisi objektif Indonesia yang plural, dan hal ini diperkuat oleh penguasaan Syaikh Yusuf terhadap aspek-aspek Islam, baik secara lahir maupun batin. Pemahaman Syaikh Yusuf yang komprehensif ini membuat dakwahnya jauh dari unsur-unsur pemaksaan akan doktrin agama.

Sementara itu, etika sebagai metode merupakan faktor yang terkait dan berpengaruh terhadap keberhasilan dakwah. Peng-

${ }^{25}$ Smart, Ninian, World Philosophies (New York: Rontledge, 1999). Smith, Linda, dan William Raeper, A Beginner Guides to Ideas (terj.) (Yogyakarta: Kanisius, 2000), hlm. 209.

${ }^{26}$ Johnson, Raynor C., A Religious Outlook for Modern Man (McGraw-Hill Book Company, New York, 1969), hlm. 1-8. 
ajaran yang metodis-adaptif oleh Syaikh Yusuf sangat jauh dengan metode dakwah sekarang ini, yang tidak jarang disertai oleh kekerasaan dan teror. Dalam sepak terjangnya, Syaikh Yusuf tidak pernah melakukan provokasi kepada pengikutnya untuk membenci kelompok lain karena alasan berbeda agama.

Corak etika Syaikh Yusuf juga berbeda dengan pola-pola dakwah yang dikembangkan sekarang ini. Etika dakwah Syaikh Yusuf berlangsung secara rasional, estetis, dan etis sehingga mudah diterima oleh masyarakat. Hal ini tidak hanya ditopang oleh keselarasan pandangannya tentang manusia sebagai hamba Tuhan, tetapi juga karena adanya kesejajaran intensitas amal dan perilakunya secara lahir dan batin, atau sebagai corak dasar dakwah yang sufistik. Oleh karena itu, metode dan substansi dakwah Syaikh Yusuf perlu diapresiasi dalam konteks Indonesia sekarang ini, karena coraknya yang mengayomi, menyejukkan, dan mencerahkan serta jauh dari tindakan anarkis dan teror, sehingga Islam sebagai rahmatan lil alamin dapat diwujudkan.

Ajaran pokok etika Syaikh Yusuf dalam dakwahnya, sebagaimana dikemukakan dalam Zubdatul Asrar, adalah tentang akhlak yang baik kepada semua makhluk Tuhan. Dalam hal ini Syaikh Yusuf mengatakan:

Wa yajiu alihi aydlan tahsinul khuluqi ma'al khalaiq kulluhum liannahu sallallahu alaihi wasallam qad suila 'an ayyinnasi, aqrabu ilaika yaumal qiyamah yaa Rasulallah fa ajaba anhu sallallahu alaihi wasallam innama buitstu liutammima makaarimal akhlak. Falihadza qala ba'du ahli suluki radiallahu anhu, at tasawwuf huwa husnul khulqi faman laysa lahu husnul khuluqi, laa tasawwafa lahu, fafham dzalika, tsumma tadammana jumlata husnil khuluyqi aydan fi qaulihi sallallahu alahi wasallam, akrim al duyuf walau kana kafiran.

Terjemahannya adalah:

Dan hal yang terpenting juga adalah etika atau akhlak yang baik. Karena Rasulullah Saw. pernah ditanya, "siapakah orang yang paling 


\section{Pesan Dakwah dan Etika Religius Dakwah dalam Karya Syaikh Yusuf}

dekat denganmu pada hari kiamat hai Rasulullah?" Maka dijawab oleh Rasulullah Saw., "bahwa sesungguhnya aku diutus untuk menyempurnakan akhlak yang mulia. Oleh karena itulah berkata sebagian ahli tasawuf: "Tasawuf adalah akhlak yang mulia, barangsiapa yang tidak berakhlak mulia maka ia tidak bertasawuf. Pahamilah itu." Akhlak yang mulia itu tercakup dalam sabda Rasul sebagai berikut: "Tempatkanlah manusia sesuai dengan derajatnya masing-masing". Dan sabdanya: "Muliakanlah tamu meskipun ia adalah orang kafir." (Dalam Lubis, 1996: 88-89).

Dakwah Syaikh Yusuf secara prinsipil berdasar pada etika, bahwa perbuatan yang baik dengan moral yang baik terhadap sesama merupakan dakwah utama yang dianjurkan oleh Islam. Dengan dakwah melalui etika dan perilaku yang baik, ketentraman masyarakat yang majemuk dapat terjaga, sebagaimana telah ditunjukkan dalam sejarah awal Islam di Indonesia. Meskipun dalam perkembangannya muncul kekerasan, hal itu tidaklah layak disebut sebagai proses dakwah, tetapi merupakan kesempitan berpikir dari sebagian kaum muslim.

Dalam kaitannya dengan etika Islam pada periode Islam awal di Makah dan Madinah, etika Islam yang diterapkan Nabi menjadi begitu penting, sebagai suatu aturan dalam berperilaku karena hal itu sangat dibutuhkan bagi masyarakat individualistik yang pada saat itu secara populasi sedang berkembang. ${ }^{27}$

Dalam perjalanan sejarah Islam di Nusantara, khususnya di Sulawesi Selatan, hubungan yang baik antara Sulawesi Selatan dan Aceh merupakan aspek sejarah Islam Nusantara yang positif dan relevan bagi pengembangan dakwah selanjutnya. Menurut Mattulada, kerajaan di Sulawesi yang mula-mula menerima Islam adalah Kerajaan Gowa-Tallo sekitar tahun 1014 H (1605). Sementara itu, menurut Thomas Arnold, ketika Portugis pertama

\footnotetext{
${ }^{27}$ Watt, W. Montgomery, What is Islam? (Washinton: Frederick A. Praeger Publishers,
} New York, 1968), hlm. 90. 
kali memasuki Sulawesi Selatan pada tahun 1540 M, telah ditemukan beberapa orang Islam di Gowa, ibukota Kerajaan Makassar dan baru pada awal abad XVII, Islam dianut oleh sebagian besar rakyat. ${ }^{28}$

Ada pula perkiraan bahwa jalur Islamisasi Indonesia bagian timur, mula-mula dari Sumatera kemudian ke Jawa, Kalimantan, Sulawesi, dan Maluku. Berkaitan dengan kasus Sulawesi, sejak abad XVI, telah terdapat perkampungan orang-orang Melayu yang beragama Islam di Makassar. Pada masa pemerintahan Raja Gowa XII, raja mendirikan masjid bagi para pedagang di Mangallekana, tempat kediaman raja di Makassar. ${ }^{29}$

Ulama dari Aceh yang datang ke Makassar terjadi sekitar tahun 1662, yaitu dengan datangnya Sayyed Jalaludin di Gowa. Ulama ini masih memiliki darah Arab yang kemudian menikah dengan salah seorang putri bangsawan Kerajaan Gowa yang bernama I Acara Daeng Tamami. Ulama ini kemudian menetap di Cikoang dan menyebarkan Islam di sana. Sebagai bukti nyata bahwa ulama ini berasal dari Aceh adalah naskah yang dibawanya, yaitu naskah karangan Nuruddin al-Raniri, Akhbarul Akhirah dan al-Shirat al-Mustaqim. Sampai sekarang naskah tersebut masih dipergunakan oleh keturunannya di Cikoang dan telah diterjemahkan ke dalam bahasa setempat. Kedatangan Sayyed Jalaluddin tampaknya menandai gelombang Islamisasi kerajaan-kerajaan Bugis Makassar, sesudah periode Dato' Ri Bandang dan kawankawan (datto tellue). Apa yang menjadi isi pengajaran dari Sayyed

\footnotetext{
${ }^{28}$ Oesman, Moerad, "Masuknya Islam di Indonesia Bagian Timur dan Hubungannya dengan Aceh Darussalam", dalam Andi Rasdiyanah (ed.), Bugis-Makassar dalam Peta Islamisasi Indonesia, Selayang Pandang tentang Beberapa Aspek (Ujung Pandang: IAIN Alauddin, 1982), hlm. 22.

${ }^{29}$ Ahmad, Muhammad, "Hubungan Gowa dengan Aceh dalam Proses Islamisasi Kerajaan Bugis-Makassar", dalam Andi Rasdiyanah (ed.), Bugis-Makassar dalam Peta Islamisasi Indonesia, hlm. 29.
} 
Jalaluddin masih dapat diketahui sampai saat ini, karena muridmurid dan keturunannya masih menjadi guru-guru agama. ${ }^{30}$

Sejarah penyebaran Islam di Sulawesi Selatan sebenarnya didahului oleh agama Katolik yang dianut lebih dahulu oleh empat raja Sulawesi Selatan, jauh sebelum Islam, yaitu Arung Alitta, Datu Suppa, Arung Bacukiki, dan Karaeng Siang. Mengapa Katolik berhasil mempengaruhinya, sementara nakhoda Bonang Syahbandar I Makassar tidak berhasil mempengaruhi masuk Islam, hal ini karena cara pendekatannya yang berbeda ${ }^{31}$ (Farid, dalam Rasdiyanah (ed.), 1982: 65). Orang Katolik tidak secara langsung menyatakan larangan-larangan agama secara drastis, sedangkan orang Islam pada waktu itu langsung menyatakan bahwa kalau Anda makan babi itu haram. Namun, dalam perkembangan selanjutnya, yang menarik adalah kedatangan tiga orang datuk dari Sumatera Barat, yaitu Khatib Sulung atau Datuk Ri Patimang, Khatib Makmur, dan Khatib Bungsu dengan gelar Datuk Ri Tiro. Sejak itu, Islam berkembang dan diterima oleh penduduk.

Tampaknya, ketiga datuk itu tidak hanya ahli dalam bidang agama, tetapi juga ahli jiwa yang diplomatis. Salah seorang di antaranya dikirim ke Bulukumba untuk menghadapi orang Kajang yang berbaju hitam kepercayaan kebatinan (patuntung), yaitu Datuk Bungsu. Datuk Bungsu adalah pilihan yang tepat karena ia ahli dalam bidang kebatinan Islam. ${ }^{32}$

Selanjutnya, penting menguraikan isi sejarah menurut Lontara yang telah diterjemahkan ke dalam bahasa Indonesia, yaitu:

\footnotetext{
30 Ibid., hlm. 33.

${ }^{31}$ Farid, Andi Zainal Abidin, Lontara Sulawesi Selatan sebagai Sumber Informasi IImiah, dalam Andi Rasdiyanah (ed.) (Ujungpandang: IAIN Alauddin), hlm. 65.

32 Ibid., hlm. 67.
} 


\section{Agama dan Bayang-Bayang Etis Syaikh Yusuf Al-Makassari}

Apabila dipertanyakan siapa sebenarnya raja pertama masuk Islam di Sulawesi Selatan, mungkin akan dijawab bahwa raja pertama masuk Islam di Sulawesi Selatan adalah Karaeng Tallo (Raja Tallo). Namun kalau dibaca Lontara, akan ditemukan jawaban yang berbeda, yaitu Datu Luwu atau Raja Luwu. Beliau mendahului Raja Tallo masuk Islam dua tahun sebelumnya, yaitu pada tanggal 13 Ramadhan 1013 Hijriah (1603). Beliau diberi gelar oleh muballig, dengan nama Sultan Muhammad dan nama pribadinya adalah La Patiware Daeng Parabu. Pada waktu tiga serangkai datang, mereka bertanya lebih dahulu tentang pusat kerajaan Bugis. Jawabannya adalah, bahwa pusat kerajaan tertua adalah Luwu, dan Datu Luwu-lah raja yang dihormati dan disegani. Akan tetapi, yang paling ditakuti adalah Raja Gowa, karena senjatanya banyak, sebab berhubungan dagang dengan orang asing. ${ }^{33}$

Pada tahap pertama, para datuk ini mengatakan bahwa:

Kami ini pedagang dari Minangkabau. Lalu mereka bertanya tentang agama yang dianut oleh Datuk Luwu. Datuk Luwu menyatakan bahwa agama kami adalah Dewata Seuwae, maksudnya Tuhan yang Maha Esa. Dengan demikian kelirulah kalau dikatakan bahwa sebelum Islam, orang Bugis itu beragama Hindu karena Dewata Seuwae itu tidak mengenal Brahmana, Siwa, dan Wisnu. Bagaimana menghadapi Tuhan itu? Raja mengatakan kami tak tahu. Maka dijelaskan bahwa Dewa Seuwae itu berada di mana-mana. Dia-lah yang menciptakan kita, menghidupkan dan mematikan kita. Kalau kami mau minta sesuatu kepada Tuhan, dengan perantaraan makelar yaitu biksu. Dia-lah yang dapat menghubungkan kami dengan Tuhan dengan perantaraan roh-roh yang sudah mati dan kami memberinya sajian songkolo. Datuk menyatakan bahwa Tuhan tidak makan dan tidak minum ${ }^{34}$ (Farid, dalam Rasdiyanah (ed.), 1982: 67-68).

Demikian pula yang terjadi pada orang Toraja. Jika mereka ditanya, "berapa Tuhanmu?, mereka menjawab "satu”, yaitu Puang Matoa. Apakah Puang Matoa itu raja? Menurut mereka, "bukan”. Dia ada di langit, tapi tidak tahu di mana. Orang Melayu itu lalu bertanya kepada Datuk Luwu, apa pesan Saweri Gading pada waktu

33 Ibid.

${ }^{34}$ Ibid., hlm. 67-68. 


\section{Pesan Dakwah dan Etika Religius Dakwah dalam Karya Syaikh Yusuf}

dia akan tenggelam? Seperti diketahui bahwa di Luwu tersebar sebuah cerita tentang Saweri Gading. Pada waktu ia akan tenggelam, lalu pergi menghadap kakeknya dan mengatakan bahwa dirinya mau berdialog dengan Tuhan. Sang kakek mengingatkan bahwa itu tidak bisa dilaksanakan karena Tuhan itu keramat sekali. Namun, Saweri Gading telah bertekad untuk mencoba dengan menggunakan ilmu. Dengan putus asa sang kakek mempersilakan. Setelah kembali dari menghadap Tuhan, Saweri Gading mulai lemah. Sang kakek lalu menanyakan apakah sudah menyaksikan sifat mustika tunggalnya Tuhan pencipta? Ketahuilah, siapa saja yang meragukan Tuhan, maka dia akan meleleh bagai lilin dan tenggelam bagai batu. Sang datuk menyambut cerita itu dengan pernyataan bahwa cerita itu sangatlah bagus. Oleh para analis, cerita di atas berkait erat dengan masalah keberagamaan.

Pesan lain lainnya adalah dia berlabuh di timur dan juga muncul di barat. Orang Melayu menyatakan bahwa mereka berasal dari barat. Setelah itu, barulah mereka mengajarkan agama Islam. Jadi, mereka tidak langsung mengajarkan surat al-ikhlas, tentang Tuhan Yang Maha Esa menurut Islam, dan juga tidak melarang sama sekali makanan dan minuman yang haram.

Di sini ditunjukkan suatu langkah penawaran agama kepada masyarakat yang pada dasarnya belum mengenal atau memahami esensi keberagamaan itu. Cerita kapan adat baru itu datang, dilanjutkan dengan keyakinan bahwa adat akan datang setelah tiga tahun ia dikubur. Jadi, Arung Matowa Wajo dikatakan Islam sebelum datangnya Islam. Raja Tallo bertanya, dengan siapa paman belajar kepadanya. Dikatakan bahwa ia belajar dengan Raja Bone, tetapi ia tidak mau mengikutinya. Demikianlah pada mulanya orang Bone tidak mau masuk Islam, tetapi setelah menganut Islam menjadi paling fanatik. Kalau ada yang tidak sembahyang dipenggal lehernya. Setelah Karaeng Tallo masuk Islam, barulah diikuti oleh Raja Gowa. Lontara menegaskan bahwa Raja Tallo 
masuk Islam pada Kamis tanggal 22-09-1605 M, bertepatan dengan 9 Jumadil Awal 1014. Penjelasan ini menunjukkan bahwa Lontara itu banyak macamnya, yaitu: Bila ingin menyelesaikan problem sejarah Bugis-Makassar maka bacalah Lontara Attorioloang (Lontara Sejarah); kalau ingin mengungkapkan peristiwa-peristiwa penting yang terjadi dan menyangkut catatan harian pada satu kerajaan bacalah Lontara Bilang; Kalau sakit, lalu ingin mencari obat, bacalah Lontara Pabbura. ${ }^{35}$ Proses dakwah yang dilakukan ketiga ulama Islam yang mengetahui tasawuf serta metode dakwah untuk masyarakat, sangat menghormati dan mengikuti adat dan budaya setempat. ${ }^{6}$ Keterangan yang jelas dari Lontara perlu diungkapkan apa adanya di sini dalam kaitannya dengan bagaimana dalam sejarah, peranan kaum sufi dan mubaligmubalig Islam yang memahami kondisi sosial masyarakat dapat dengan sukses melaksanakan tugasnya. Hal ini sangat penting agar dapat menjadi pelajaran dakwah bagi masyarakat, baik pada masa sekarang maupun yang akan datang.

Setelah Syaikh Yusuf kembali ke Indonesia tahun 1672 M, situasi politik di Makassar belum memungkinkan dirinya kembali ke Makassar. Akhirnya, Syaikh Yusuf memilih menetap di Banten, dan menikah dengan putri Sultan Banten, serta menjadi seorang syaikh yang bersuara lantang dalam berdakwah. Dengan ilmunya, dia mampu mengumpulkan ribuan murid. Ketika terjadi perselisihan antara kesultanan Banten dan Belanda, dia menjadi pemimpin perang bersama murid-muridnya dalam angkatan perang sultan. Maka tidak mengherankan bila banyak pengikut Syaikh Yusuf dalam perjuangan itu, juga merupakan muridmuridnya. Beberapa di antaranya menjadi anggota tarekat, sebagian lainnya menjadi pengikut tidak resmi. Namun demikian, orang-

\footnotetext{
${ }^{35}$ Ibid., hlm. 69.

${ }^{36}$ Ibid., hlm. 70 .
} 
orang yang tidak mengikuti tarekat pun merupakan muridmuridnya. ${ }^{37}$ Belanda mampu melumpuhkan pasukan sehingga syaikh menjadi tawanan dan diasingkan ke Sri Lanka tahun 1099 $\mathrm{H}$ dalam usia 57 tahun. Syaikh Yusuf kemudian menetap di Sri Lanka beberapa tahun dan menghabiskan waktunya dengan belajar dan menulis.

Ketika terjadi bentrokan di Jawa, Belanda menuduh Syaikh Yusuf sebagai penyebabnya dan kemudian dia diasingkan lagi untuk kedua kalinya ke Afrika Selatan hingga meninggal di pengasingan. Setelah beberapa tahun meninggal, Sultan Gowa meminta pemerintah Belanda untuk memindahkan kuburan Syaikh Yusuf ke tempat kelahirannya di Makassar. ${ }^{38}$

Dalam pengasingannya di Afrika Selatan, Syaikh Yusuf tetap berjuang untuk membela kebenaran dan keadilan dan bukan untuk mencari kekuasaan. ${ }^{39}$ Pengaruh gerakannya kemudian menyebabkan jejak dan berkembangnya keturunan Syaikh Yusuf hingga saat ini di Cape Town Afrika Selatan dan terus mengembangkan Islam di Afrika. Melihat kenyataan ini, maka dakwah Islam yang beretika yang dikembangkan Syaikh Yusuf di Afrika, misalnya, adalah perkembangan dakwah Islam yang menggembirakan dunia Islam termasuk Indonesia. Di awal telah disebutkan soal hubungan Cape Town Afrika Selatan dan Indonesia yang berlangsung sangat baik dalam pengembangan dakwah Islam, baik di Afrika Selatan maupun di Indonesia, dengan tetap mengikuti metode dakwah Syaikh Yusuf yang sesuai dengan kepribadian masyarakat Melayu atau Indonesia.

\footnotetext{
${ }^{37}$ Sewang, Ahmad, M, Islamisasi Kerajaan Gowa (Jakarta: Yayasan Obor Indonesia, 2005), hlm. 88-95.

${ }^{38}$ Darusman, Lukmanul Hakim, "Jihad in Two faces of Syariah, Case Studies of Syaikh Yusuf al Maqassary and Syaikh Daud al Fatani", Disertasi (Canberra, Australia: ANU, The Australian National University, 2008), hlm. 273.

${ }^{39}$ Shihab, hlm.179-180.
} 
Pengaruh ketokohan Syaikh Yusuf masih mewarnai hubungan antarkedua negara. Afrika Selatan telah menganggap Syaikh Yusuf sebagai pejuang muslim yang melegenda, khususnya di Cape Town. Syaikh Yusuf membangun sebuah kota yang dikenal sebagai kampung Makassar, terletak di Distrik Stellenbosch, kawasan perkebunan Anggur, 40 kilometer dari jantung kota Cape Town. Syaikh Yusuf berumur 73 tahun, dan 4 tahun terakhir hidup di Cape Town. Puncak ziarah ke makamnya adalah pada hari Paskah, bulan April, yaitu saat liburan umat Kristiani. Hal ini karena sejak zaman dulu, pekerja di perkebunan Belanda, hanya bisa berlibur saat Paskah. ${ }^{40}$

Kerena ketokohan Syaikh Yusuf inilah, Indonesia dan Afrika Selatan baru-baru ini melakukan rencana kerja sama untuk menulis ulang riwayat perjalanan dan pergulatan Syaikh Yusuf, hingga diangkat menjadi salah satu pahlawan nasional Afrika Selatan. ${ }^{41}$

Konsep-konsep penting yang digunakan Syaikh Yusuf dalam dakwah Islam adalah konsistensi dan koherensi antara dzikir, fikr dan amal, penguasaan pengetahuan yang kuat, kepribadian yang kuat, kharisma yang tinggi, kesetiaan dan ketaatan, adaptasi yang kontekstual, kesejukan dan toleransi, damai dan harmonis, serta tegas kepada penguasa yang zalim. ${ }^{42}$

Konsep-konsep Syaikh Yusuf banyak dikembangkan oleh kaum sufi selanjutnya. Konsepnya sangat relevan sebagai salah satu alternatif menyelesaikan persoalan kemanusiaan. Humanisme kaum sufi bebeda dengan humanisme Barat, yang tidak memiliki

\footnotetext{
${ }^{40}$ Salam, Solichin, Syaikh Yusuf "Singa dari Gowa" (Ulama Kaliber Internasional) (Jakarta: Yayasan Pembina Generasi Muda Indonesia Bekerja Sama dengan Gema Salam, 2004), hlm. 42.

${ }^{41}$ Kompas, 18 Maret 2008.

42 Ibid.
} 
muatan dan wawasan moral dan spiritual karena muncul dari ontologi dan epistemologi yang sangat mengagung-agungkan manusia, yang menjadikan manusia sebagai pusat dan ukuran segala-galanya. 



\section{Bab V REFLEKSI TEORETIS ETIKA RELIGIUS SYAIKH YUSUF}

Pada dasarnya, setiap ilmu pengetahuan saling berhubungan, baik yang sifatnya berdekatan, pertengahan maupun yang berjauhan. Ilmu-ilmu yang berhubungan dengan ilmu akhlak atau etika dikategorikan berdekatan dengan ilmu tasawuf, ilmu tauhid, ilmu pendidikan, ilmu jiwa, dan filsafat, sedangkan yang dikategorikan pertengahan adalah ilmu hukum, ilmu sosial, ilmu sejarah, dan ilmu antropologi. Sementara itu, ilmu-ilmu yang jauh hubungannya dengan ilmu akhlak adalah ilmu fisika, biologi, dan ilmu politik. Filsafat etika adalah sebuah upaya untuk mensistematisasikan pengetahuan tentang hakikat moralitas dan apa yang dituntut, seperti yang diucapkan oleh Socrates, bagaimana seharusnya hidup, dan mengapa harus hidup demikian ${ }^{1}$.

Pandangan tentang hakikat moralitas memiliki kaitan yang erat dengan Islam, sebab satu pesan penting dalam ajaran agama Islam adalah pembentukan moral atau akhlak yang baik, Islam menyebutnya hablum minallah (hubungan dengan Allah) dan hablum minannas (hubungan dengan manusia).

Di samping itu, pandangan etika Syaikh Yusuf termasuk dalam kategori etika religius karena pandangan-pandangan tersebut

Rachels, James, The Elements of Moral Philosophy (terj.) (Yogyakarta: Kanisius, 2004), hlm. 17. 
memiliki landasan pada ajaran agama Islam yang menekankan pada harmonisasi kehidupan dunia dan akhirat. Artinya ajaranajaran Islam mengajarkan bahwa etika yang dilakukan dalam tindakan hidup sehari-hari mempunyai konsekuensi dan tanggung jawab tidak hanya kepada sesama manusia, tetapi juga kepada Tuhan.

\section{A. Refleksi dalam Konteks Keindonesiaan}

Terkait dengan krisis kemanusiaan yang terjadi di Indonesia dewasa ini, ada dua teori yang perlu ditempatkan, yaitu: humanisme dan radikalisme. Kedua teori ini akan diangkat dalam dua kenyataan yaitu humanisme yang diajarkan oleh Syaikh Yusuf yang masih relevan untuk diaktualisasikan, dan radikalisme agama yang digerakkan oleh organisasi-organisasi seperti Front Pembela Islam (FPI) yang muncul di Indonesia.

Humanisme yang dikembangkan oleh kaum sufi seperti Syaikh Yusuf sangat kontras dengan humanisme model Barat, yang tidak memiliki muatan moral dan wawasan spiritual karena ia muncul dari ontologi dan epistemologi yang mengagungkan manusia, yang menjadikan manusia sebagai pusat dan ukurannya. Humanisme Barat, kosong dan semu karena lebih mementingkan peradaban pikir (Iptek) dan materi yang pada akhirnya berujung pada dehumanisasi, demoralisasi, dan despiritualisasi.

Dimensi rasa dan moral yang tidak dikembangkan secara sejajar dengan dimensi ilmu dan teknologi, dapat menggelincirkan manusia pada keadaan hidup yang tidak jelas karena ia tidak memiliki tujuan yang pasti dan bermakna. Hal ini akan menyebabkan keterasingan, ketidaktentraman, sebab kesenangan materi an sich sama sekali tidak akan pernah memberi kebahagiaan sejati. Namun kritik tentang humanisme kaum sufi sebagai humanisme yang tidak memberi tempat bagi kehidupan dunia modern, 


\section{Refleksi Teoretis Etika Religius Syaikh Yusuf}

disebabkan oleh ajaran zuhud yang menekankan agar manusia hidup dalam kesederhanaan. Tetapi kritik atas makna zuhud dalam kesufian bisa berkembang secara dinamis dan fleksibel. Ada zuhud yang ekstrim dan ada pula yang moderat. Zuhud moderat tidak harus meninggalkan dunia tetapi mengandung makna tidak terikat oleh dunia apalagi dikendalikan oleh kehidupan duniawi. Kehidupan dunia tetap layak digeluti namun ia tidak menjadi tujuan utama yang dicari. Kehidupan dunia adalah alat atau sarana untuk meraih hidup yang lebih layak, lebih bahagia untuk mencapai kebahagiaan kekal kelak. ${ }^{2}$

Syaikh Yusuf sendiri menggeluti hidup dunia secara intens. Ia menerima tawaran untuk menjadi pejabat negara dalam bidang keagamaan, yaitu menjadi tokoh majelis ulama atau mufti kerajaan Banten. Ia juga turut berjuang secara nyata, melakukan perang melawan kolonial Belanda. Dalam keseharian, Syaikh Yusuf hidup layaknya sebagai manusia biasa yang mempunyai isteri dan keturunan. Hal ini membuktikan bahwa hidup kesufian yang diajarkan oleh Syaikh Yusuf tidak mengharuskan manusia meninggalkan kehidupan duniawi.

Dalam konteks keindonesiaan yang beraneka ragam suku, budaya, dan ras serta keyakinan maka perlu dirumuskan kembali etika dan tata susila yang diperlukan. Adapun beberapa hal yang perlu dirumuskan adalah pemahaman kembali pesan-pesan Tuhan dalam Al-Qur'an, bagaimana pesan-pesan tersebut dipahami oleh kaum terpelajar dengan merujuk pada sejarah awal mula munculnya agama serta kondisi sosial dan kebudayaan serta politik masyarakat di mana agama tersebut berkembang, dan bagaimana kemudian para pendakwahnya merumuskan metode filsafat

Cawidu, Harifuddin, "Peringatan 300 Tahun Mendaratnya Syaikh Yusuf AlKhlwaty Al Makassary di Afrika Selatan", Makalah Seminar Nasional, Ujung pandang: Universitas Hasanuddin, 1994, hlm.12. 
dakwah, dari yang sederhana hingga sistematis sesuai dengan objek dakwahnya.

Inti dakwah Syaikh Yusuf, adalah kebaikan moral dan etika luhur pada sesama manusia, bahkan pada sesama makhluk Tuhan. Dalam hal ini ajaran-ajaran etikanya yang berlandaskan ajaran Islam mengandung pesan-pesan moral dan spiritual yang dapat digali serta dikembangkan, terkait dengan filsafat dakwah bagi masyarakat Indonesia yang majemuk. Hal ini penting untuk ditekankan, karena sebagai putra daerah, atau ulama yang lahir di bumi Nusantara, Syaikh Yusuf telah membuktikan bahwa selain memahami ajaran-ajaran Islam dengan baik secara lahiriah atau fiqh dan secara batin, Syaikh Yusuf juga memahami sejarah dan kebudayaan bangsanya. Ragam pengetahuan tersebut membuat dakwah Syaikh Yusuf berhasil,disamping itu ia dapat membandingkan dan mempertimbangkan kondisi-kondisi psikologis serta sosial budaya dan pandangan filsafat masyarakat berdasarkan kebudayaannya.

Dalam konteks keindonesiaan, hal ini patut menjadi refleksi dan pelajaran untuk pengembangan dakwah Islam, sebab kegagalan akan terjadi apabila para pendakwah tidak dapat mendengarkan suara kaumnya sendiri, tetapi meniru dan mendengar suara-suara ulama dari luar negaranya tanpa mempertimbangkan kondisi masyarakat. Oleh karena itu, perumusan metodologi dakwah bagi masyarakat Indonesia masa kini dan masa depan seharusnya juga berlandaskan pada contoh-contoh teladan yang diberikan oleh para ulama Indonesia dengan merujuk pada ulama Islam yang lain dalam sejarah.

Modernisasi dan industrialisasi kadang berakibat degradasi moral yang dapat menjatuhkan harkat dan martabatnya. Oleh karena itu, sufisme pada masa sekarang memiliki tanggung jawab moral untuk membawa masyarakat kembali kepada fitrahnya 


\section{Refleksi Teoretis Etika Religius Syaikh Yusuf}

dengan pendekatan kepada Tuhan melalui penentangan terhadap ketidakadilan. Dalam sejarah Syaikh Yusuf telah membuktikan hal tersebut. Pada proses kemerdekaan Republik Indonesia, tarekat, tidak hanya tarekat Syaikh Yusuf tetapi juga tarekat-tarekat lainnya pernah menjadi basis perjuangan melawan penjajah. Selain tarekat Khalwatiyah Syaikh Yusuf, yang perlu disebutkan kembali misalnya peristiwa perjuangan di Cianjur (1885 M), Cilegon (1888 M), dan peristiwa Garut (1919 M). ${ }^{3}$

Di Indonesia gerakan dakwah disebut juga gerakan keagamaan. Para akademisi menggunakan berbagai istilah untuk menggambarkan gerakan komunitas muslim. Dan studi tentang gerakan komunitas muslim dengan segala labelnya telah banyak digunakan oleh para peneliti dan akademisi, seperti radikal, fundamentalis, militan, revivalis dan pemaknaannya disatukan dengan paradigma yang sama yaitu eksklusivitas. ${ }^{4}$

Di Indonesia, penggunaan kata gerakan Islam radikal lebih tepat dibandingkan dengan kata Islam fundamentalis. Radikalisme ditandai dengan penolakan secara menyeluruh terhadap tertib sosial yang sedang berlaku, karena adanya kejengkelan moral yang kuat terhadap kaum yang memiliki hak-hak istimewa dan berkuasa. Keanggotaan gerakan radikal tersebut terbatas pada strata sosial rendahan, kaum tertindas atau yang kurang mampu. Di Indonesia, organisasi FPI (Front Pembela Islam) diposisikan sebagai gerakan radikal dan para pengikutnya sebagai komunitas radikal5.

Radikalisme di Indonesia merupakan suatu reaksi bukan aksi. Kemunculannya dipicu oleh persoalan domestik dan konstelasi

3 Syukur, HM. Amin, Muhayya, Abdul, (eds.), Tasawwuf dan Krisis (Semarang: Pustaka Pelajar dan IAIN Walisongo, 2001), hlm. 117.

4 Rosadi, Andri, Hitam Putih FPI (Front Pembela Islam) ( Jakarta: Nun Publisher, 2008), hlm. 31.

5 Ibid., hlm. 33. 
politik internasional yang dinilai telah memojokkan kehidupan sosial politik umat Islam. Persoalan domestik misalnya adalah pembantaian kiai di Jawa Timur, tragedi Poso, Ambon dan menjamurnya kemaksiatan di masyarakat. Secara ringkas dapat dikatakan bahwa kemunculan kelompok-kelompok radikal di Indonesia bisa dikaitkan dengan fenomena yang terjadi. Front Pembela Islam (FPI) muncul karena premanisme dan kemaksiatan yang sudah tidak mampu lagi dikontrol oleh negara. Tugas ini diambil alih dengan argumen agamis yaitu, amar makruf dan nahi munkar, demikian juga dengan munculnya Majelis Mujahidin Indonesia (MMI) dengan Hizbut Tahrir Indonesia (HTI). ${ }^{6}$

Di Indonesia, FPI disebut-sebut sebagai gerakan yang paling radikal dalam konteks dakwah dan FPI merupakan gerakan perlawanan terhadap kemungkaran yang terjadi di masyarakat. Kemungkaran yang terjadi dipahami dengan teori konspirasi, sehingga menimbulkan perasaan terancam yang berlebihan. Pemahaman berdasarkan teori konspirasi tersebut digabungkan dengan ajaran agama. Artinya, FPI menggunakan dua paradigma untuk memahamai realitas, yaitu teori konspirasi dan ajaran agama. Perlawanan muncul disebabkan karena adanya penilaian bahwa aparat negara bersikap pasif terhadap kemungkaran yang terjadi. Kelompok ini mengambil alih tugas kepolisian, sehingga sering menimbulkan konflik vertikal dengan negara. Pada sisi lain, ruang publik dalam masyarakat sipil juga digunakan FPI untuk memperjuangkan ide dan gagasannya, sehingga konflik juga terjadi di tataran horizontal. Relasi antara FPI dengan negara dan masyarakat yang saling mempengaruhi inilah yang menentukan arah perkembangan FPI.7 Hubungan saling mempengaruhi ini menyebabkan terjadinya perubahan-perubahan internal dalam FPI, baik

6 Ibid., hlm. 66.

7 Ibid., hlm. 215. 


\section{Refleksi Teoretis Etika Religius Syaikh Yusuf}

dalam tataran paradigma maupun aksi. Perubahan reaksi negara juga terus berlangsung, sesuai dengan perubahan yang terjadi dalam FPI. Penangkapan oleh aparat keamanan dan wacana pembubaran FPI merupakan bagian dari reaksi negara tersebut. Sementara itu, keluhan dan pro-kontra di masyarakat juga merupakan bagian dari wujud relasi yang saling mempengaruhi.

Ada keyakinan berdasarkan ajaran agama bahwa kemungkaran akan menimbulkan azab dan bencana, untuk menghindari hal itu maka FPI mengambil inisiatif untuk menegakkan hukum dengan caranya sendiri. Dalam konteks masyarakat sipil yang didasarkan pada supremasi hukum, FPI seharusnya menyampaikan tuntutan dan protes melalui institusi negara, agar tidak terjebak pada cara-cara yang anarkis. Namun FPI menggunakan caranya sendiri, cara yang berbeda dengan institusi sosial lainnya. Akibatnya kehadiran FPI bukannya memperkuat masyarakat sipil tetapi malah menambah kompleksnya permasalahan. Mungkin bisa dikatakan, FPI adalah anomali dalam masyarakat sipil. ${ }^{8}$

Apabila menengok sejarah Islam Nabi Muhammad Saw. membangun masyarakat peradaban setelah berhijrah dari Makah ke Madinah dilandasi dengan nilai-nilai kemanusiaan yang menjunjung tinggi persamaan hak, perlindungan terhadap kaum minoritas, menghormati agama dan ibadah orang lain, menghormati kebebasan pendapat dan beragama. Oleh karena itu perilaku dan tindakan kekerasan apalagi mengatasnamakan agama Islam sebagaimana yang dicontohkan oleh Nabi Muhammad Saw. sangat bertentangan dan merupakan tindakan dakwah yang kontra produktif, tidak mencerminkan spirit masyarakat sipil yang pernah dibangun oleh Nabi Muhammad Saw. di Madinah dengan landasan menegakkan dakwah atas kesabaran dan kasih sayang (nasihat dalam kebenaran dan kasih sayang).

8 Ibid., hlm. 216-217. 


\section{B. Rekonstruksi dan Tawaran Metodologis}

Sebelum melangkah ke perdebatan pemikiran etika, penting untuk membahas dan memberikan gambaran tentang hakikat ilmu. Ilmu merupakan kumpulan pengetahuan yang mempunyai ciriciri tertentu yang membedakan ilmu dengan pengetahuan yang lain. Kajian tentang hakikat keilmuan merupakan kajian filsafat yang biasanya meninjau dari tiga segi penting yaitu, ontologi, epistemologi dan aksiologi ilmu pengetahuan. Filsafat mempelajari masalah ini sedalam-dalamnya dan hasil pengkajiannya merupakan dasar bagi eksistensi ilmu. Ciri-ciri keilmuan didasarkan pada jawaban yang diberikan ilmu terhadap tiga pertanyaan pokok. Ketiga pertanyaan pokok itu mencakup masalah tentang apa yang ingin diketahui? Bagaimana cara mendapatkan pengetahuan tersebut? Apa nilai kegunaannya?9

Ontologi membahas tentang apa yang ingin diketahui, yaitu pengkajian teori tentang yang ada. Kemudian bagaimana cara mendapatkan pengetahuan mengenai objek tersebut. Pertanyaanpertanyaan itu merupakan kajian epistemologi, yaitu teori pengetahuan. Sedangkan tentang nilai kegunaan pengetahuan merupakan kajian aksiologi. Setiap bentuk buah pemikiran manusia dapat dikembalikan pada dasar-dasar ontologi, epistemologi, dan aksiologi dari pemikiran tersebut.

Epistemologi atau teori pengetahuan, membahas secara mendalam segenap proses yang terlihat dalam usaha untuk memperoleh pengetahuan. Ilmu merupakan pengetahuan yang didapat melalui proses tertentu yang dinamakan metode keilmuan. Metode inilah yang membedakan ilmu dengan buah pemikiran yang lain. Dengan kata lain, ilmu adalah pengetahuan yang diperoleh dengan menerapkan metode keilmuan. Karena ilmu merupakan sebagian

Suria Sumantri, Jujun, Filsafat IImu, Sebuah Pengantar Populer (Jakarta: Pustaka Sinar Harapan, 1993), hlm. 4. 


\section{Refleksi Teoretis Etika Religius Syaikh Yusuf}

dari pengetahuan, yakni pengetahuan yang memiliki sifat-sifat tertentu, maka ilmu dapat disebut juga pengetahuan keilmuan. Agar tidak terjadi kekacauan antara pengetahuan yang diperoleh dari belajar (ilmu atau science) dengan pengetahuan yang diperoleh dari informasi atau pengetahuan (knowledge), maka dipergunakan istilah ilmu untuk ilmu pengetahuan. ${ }^{10}$

Ditinjau dari pengetahuan, ilmu lebih bersifat kegiatan daripada sekadar produk yang siap dikonsumsi. Kata sifat dari keilmuan lebih mencerminkan hakikat ilmu daripada istilah ilmu sebagai kata benda. Kegiatan ilmu sangat dinamis dan tidak statis selama hal itu terbatas pada objek empiris dan pengetahuan tersebut diperoleh dengan mempergunakan metode keilmuan, maka sah disebut keilmuan. Hakikat ilmu tidak berhubungan dengan titel, profesi atau kedudukan. Hakikat ilmu ditentukan oleh cara berpikir yang dilakukan menurut persyaratan keilmuan.

Sedangkan aksiologi adalah pengetahuan tentang nilai yang memberikan penilaian baik atau buruknya suatu tindakan. Jika ditinjau dari segi perkembangannya, sama seperti semua unsur kebudayaan manusia sebelumnya dalam mencari pengetahuan. Karena pada dasarnya sejarah berpikir manusia, terdiri dari dua pola cara berpikir secara rasional dan cara berpikir empiris

Cara berpikir secara rasional, berdasar pada paham rasionalisme, yakni gagasan atau ide tentang kebenaran yang ada. Pikiran manusia dapat mengetahui ide, namun tidak menciptakannnya dan tidak pula mempelajarinya melalui pengalaman. Dengan kata lain, ide tentang kebenaran yang menjadi dasar pengetahuan diperoleh melalui berpikir secara rasional, terlepas dari pengalaman manusia. Sistem pengetahuan dibangun secara koheren di atas landasan-landasan pernyataan yang sudah pasti. Namun dari

${ }^{10}$ Ibid., hlm. 9. 
manakah mendapatkannya bila kebenaran itu bercerai dari pengalaman manusia yang nyata? Dari sinilah kaum rasionalis mulai mendapatkan kesulitan untuk mendapatkan konsensus yang dapat dijadikan landasan berpikir bersama. Tiap orang cenderung untuk percaya kepada kebenaran, lalu bagaimana bisa sampai pada suatu konsensus jika hanya berdasarkan pada apa yang dianggap benar oleh masing-masing? ${ }^{11}$

Sedangkan cara berpikir secara empiris berpendapat pengetahuan tidak secara a priori diperoleh atau tahu tanpa pengamatan, melainkan harus diperoleh dari pengalaman atau a posteori. Lalu berkembanglah apa yang dinamakan pola berpikir empiris yang semula berasal dari sarjana-sarjana Islam. Dan kemudian terkenal di dunia Barat lewat tulisan Francis Bacon (1561-1626) dalam bukunya Novum Organum tahun 1920. Pola berpikir rasional pun sebenarnya dikenal oleh ahli-ahli pikir Barat melalui pembahasan ahli-ahli filsafat Islam terhadap filsafat Yunani yang dilakukan antara lain oleh al-Kindi (809-873), al-Farabi (881-961), Ibnu Sina (980-1037) dan Ibnu Rusyd (1126-1198). Di samping ahli filsafat, juga ahli dalam bidang keilmuan. Filsafat Ibnu Rusyd sendiri, memiliki pengaruh yang besar dalam dunia pemikiran Barat yang kemudian dikenal dengan sebutan Averoism. Sarjana Islam juga menyumbangkan kemajuan ilmu dengan pengembangan aljabar oleh Khawarizmi, geometri oleh al-Battani serta penggunaan angka desimal, sebagaimana sekarang dipergunakan. ${ }^{12}$

Sehubungan dengan penerapan, serta distribusi filsafat ilmu dalam sistem pendidikan, maka terdapat tiga kesalahan yang menyebabkan lemahnya sistem pendidikan masa kini. Pertama, adalah gagasan yang keliru bahwa sekolah diadakan hanya untuk melatih anak-anak baik laki-laki maupun perempuan untuk mampu

\footnotetext{
11 Ibid., hlm.10.

12 Ibid., hlm. 10-11.
} 


\section{Refleksi Teoretis Etika Religius Syaikh Yusuf}

bergaul, berinteraksi dengan kelompoknya, melengkapi dengan ketrampilan kehidupan sosial, mampu menyesuaikan diri dengan keluarga dan masyarakat. Sesungguhnya semua itu hanyalah salah satu dari tujuan pendidikan. Tujuan lain yang lebih penting adalah melatih pemikiran individu seintensif mungkin dan mendorongnya ke arah pemikiran yang beraneka ragam, sebab kehidupan yang pokok bersifat pribadi.

Kesalahan kedua terletak pada konstruksi sosial bahwa proses pendidikan selesai ketika anak beranjak dewasa, Banyak sekali pelajar muda yang meninggalkan proses belajarnya. Kesalahan yang ketiga terletak pada suatu gambaran yang salah, bahwa proses belajar dan mengajar harus memperlihatkan hasil yang serba membawa keuntungan dan membawa ke arah keberhasilan. ${ }^{13}$ Konsekuensi menganut prinsip-prinsip ilmu pengetahuan ada beberapa, pertama dari segi praktis, jika hal itu merupakan sesuatu paling baik dari yang dimiliki, maka ilmu adalah sangat berguna. Kedua, dilihat secara teoretis, manusia hampir tidak mempunyai sesuatu yang lebih baik daripada ilmu dalam hal menjelaskan alam. Ilmu memberikan perspektif, baik untuk gejala yang diamati maupun fakta yang bersifat mungkin atau peluang. Ketiga, sikap bahwa semua orang yang berpikir harus memihak ilmu dan menentang kekuasaan manusia terlebih bila terjadi kontradiksi. Kontradiksi ini mungkin terjadi jika ilmu pengetahuan bertentangan dengan ideologi, yakni argumentasi yang disusun berdasarkan kekuasaan baik berupa kekuasaan manusia, sosial, maupun kekuasaan-kekuasaan lainnya. ${ }^{14}$

Selain itu, penilaian hakikat ilmu tentang yang baik dan buruk, perlu merujuk pada pandangan Aristoteles tentang kebaikan. Menurut Aristoteles, kebaikan harus didasarkan pada intelektual

\footnotetext{
${ }^{13}$ Ibid., hlm. 49.

${ }^{14}$ Bochenski, J.M., "Apakah Sebenarnya Berpikir", dalam Jujun S. Suria Sumantri, IImu dalam Perspektif, (Jakarta: Yayasan Obor Indonesia, 2006), hlm. 57.
} 
atau ilmu dan moral. Dengan demikian, kebaikan akan memiliki landasan filosofis yang kuat dan dapat menjadikan pelakunya menjadi baik bila melakukannya sebagai kebiasaan, ${ }^{15}$ karena manusia merupakan pelaku yang bertanggung jawab terhadap tindakan. ${ }^{16}$ Seseorang akan memiliki fondasi intelektual dan psikologis yang baik, apabila tindakannya dilandasi oleh moral dan intelektual yang baik pula.

Sedangkan akibat keempat, karena ilmu untuk sebagian besar hanya memberikan pernyataaan yang bersifat mungkin, maka hal tersebut dapat ditolak berdasarkan sesuatu yang pasti. Ilmu bukanlah sesuatu yang pasti dan jika menemukan sesuatu yang pasti, yang mana penemuan itu menentang apa yang dipertahankan ilmu, maka harus memihak kepada sesuatu yang pasti tersebut dan menentang teori keilmuan.

Kelima, ilmu hanya mempunyai kemampuan dalam bidangnya sendiri. Misalnya, seorang dokter yang mengatakan kesadaran dalam struktur otak manusia memililiki argumen yang dapat diterima akal, karena sang dokter telah banyak membedah mayat. ${ }^{17}$ Jadi hal tersebut merupakan hasil ilmu pengetahuan yang juga berdasarkan pengalaman. Jika pengetahuan tentang hal tersebut dianggap final, dan sang dokter dianggap telah mengetahui seluruh seluk beluk struktur otak, maka hal tersebut malapetaka bagi yang tidak memahami permasalahan dalam bidang tersebut. Alasannya adalah karena masih banyak bagian yang luas dari wilayah pengetahuan tentang struktur otak yang belum pernah diselidiki. Keterbatasan yang ada pada manusia menyebabkan manusia tidak mungkin menguasai secara komprehensif seluruh bagian dari ilmu pengetahuan. Ilmu pengetahuan sedemikian luas tak terbatas,

\footnotetext{
${ }^{15}$ Aristotle, Nicomachean Ethics, (London: Prentice Hall, 1999), hlm. 33.

16 Ibid., hlm. 64-65.

17 Boechenski, hlm. 57-58.
} 


\section{Refleksi Teoretis Etika Religius Syaikh Yusuf}

sehingga seakan-akan, ilmulah yang menguasai manusia dan bukan manusia yang menguasai ilmu, maka manusia tidak akan pernah menguasai seluruh ilmu pengetahuan.

Untuk itu, pengetahuan tentang filsafat penting bagi manusia sebab pemikiran yang salah yang dapat menguasai manusia dapat membahayakan kehidupan. ${ }^{18}$ Selain itu, kemampuan seseorang untuk memperbaiki kesalahan dalam pengujian diperoleh dari pengalaman, karena pengalaman sangat berfaedah dalam mengembangkan proses pemikiran yang aktif. ${ }^{19}$ Berteori secara benar, didukung dengan pengamatan yang cermat dan teliti, adalah syarat mutlak bagi kemajuan keilmuan, karena ilmu senantiasa mengikuti proses pertumbuhan dan perkembangan masyarakat.

Salah satu elemen penting dalam ilmu pengetahuan adalah fakta. Sebab fakta merupakan sesuatu yang ada, apakah tiap orang berpikir demikian atau tidak. ${ }^{20}$ Seluruh aspek kognitif yang ditinjau dari sudut biologis merupakan bagian dari proses penyesuaian terhadap fakta-fakta. Proses ini merupakan sesuatu yang terdapat dalam semua kehidupan dalam tingkat yang berbeda-beda. Akan tetapi, biasanya proses itu tidak disebut kognitif sebelum ia mencapai suatu tingkat perkembangan tertentu, sebab, terdapat batasan yang tajam yang membedakan antara hewan dengan manusia. Oleh karena itu, menjadi sukar untuk mengatakan dengan tepat pada titik mana melangkah kepada sesuatu yang ditinggikan dengan pengetahuan. Pada setiap tahap, tentunya terdapat penyesuaian diri dengan lingkungan. ${ }^{21}$ Filsafat sebagaimana ilmu

\footnotetext{
18 lbid., hlm. 59.

${ }^{19}$ Davis, W.M., "Kaidah-Kaidah Ilmu yang Masuk Akal: Suatu Dongeng tentang Pasang", dalam Jujun S. Suria Sumantri, Ilmu dalam Perspektif, hlm. 64.

${ }^{20}$ Russel, Bertrand, Fakta, Kepercayaan, Kebenaran, dan Pengetahuan, dalam Jujun S. Sumantri, Ilmu dalam Perspektif, hlm.70.

${ }^{21}$ Ibid., hlm. 71.
} 
pengetahuan harus menyadari bahwa meskipun ketepatan yang sempurna tidak mungkin, namun berbagai teknik dapat dibuat untuk mengurangi kekaburan dan ketidakmenentuan secara bertahap. Kebenaran merupakan suatu kesesuaian antara kepercayaan dan fakta. Bila hubungan ini tidak ada, maka kepercayaan tersebut adalah salah.

Dengan demikian, jelas bahwa kepercayaan adalah bagian dari pengetahuan yang benar, dan tidak sebaliknya. Mengenai kepercayaan yang benar dan bukan merupakan pengetahuan, contohnya ada seseorang yang memperhatikan jam yang tidak berjalan, meskipun ia berpikir bahwa jam itu berjalan, karena kebetulan ia melihat jam itu pada waktu yang tepat: orang ini memperoleh suatu kepercayaan yang benar tentang waktu, tetapi tidak dapat dikatakan memiliki pengetahuan. ${ }^{22}$

Pengetahuan tentang awal mula timbulnya ilmu dapat diketahui pada perkembangan sejarah manusia. Suatu usaha awal di bidang keilmuan yang tercatat dalam lembaran sejarah, dilakukan oleh bangsa Mesir. Fenomena banjir Sungai Nil yang terjadi setiap tahun, ikut menyebabkan berkembangnya sistem almanak, geometri dan kegiatan survey. Keberhasilan perumusan sistem almanak dan geografi serta survey yang dilakukan oleh orang Mesir ini kemudian diikuti oleh bangsa Babylonia dan Hindu yang memberikan sumbangan-sumbangan yang berharga meskipun tidak seintensif kegiatan bangsa Mesir. Setelah itu muncul bangsa Yunani yang menitikberatkan pada pengorganisasian ilmu dan bukan hanya menyumbang pada perkembangan ilmu astronomi, kedokteran dan sistem klasifikasi Aristoteles, namun juga silogisme yang menjadi dasar bagi penjabaran secara deduktif pengalaman-pengalaman manusia. Terlepas dari tendensi

22 Ibid., hlm. 82. 


\section{Refleksi Teoretis Etika Religius Syaikh Yusuf}

untuk menitikberatkan teori dengan sering melupakan pengalaman empiris dan kurang memperhatikan percobaan-percobaan sebagai sumber bukti-bukti keilmuan, bangsa Yunani dapat dianggap sebagai perintis dalam mendekati ilmu dengan cara sistematis.

Pendekatan silogistik adalah satu-satunya metode yang efektif dalam cara berpikir secara sistematis dalam zaman Yunani dan Romawi sampai masa Galileo dan Renaissans. Cara berpikir pada Abad Pertengahan berdasarkan silogisme ini mencapai puncaknya yang ekstrim tanpa memperhatikan peringatan Aristoteles, manusia berpikir seakan-akan seperti gymnastik mental tanpa hubungan sama sekali dengan pengamatan dan pengalaman alam nyata. ${ }^{23}$

Sebagai contoh, bagaimana memecahkan masalah mengenai jumlah gigi seekor kuda. Masalah ini bukan didekati dengan mengamati dan menghitung gigi kuda namun dipecahkan secara logika. Hal ini tentu saja adalah merupakan kesalahan. Bertrand Russel berkata: "Untuk manusia modern yang terdidik, seakanakan suatu hal yang biasa bahwa kebenaran suatu fakta harus ditentukan oleh pengamatan dan tidak didasarkan pada konsultasi dengan seorang ahli”. Walaupun begitu hal ini benarbenar suatu konsepsi modern, sesuatu yang hampir tidak pernah dilakukan sebelum abad XVII. Aristoteles bersikeras bahwa perempuan yang mempunyai gigi lebih sedikit, meskipun dia pernah kawin dua kali, tak pernah terlintas dalam pikirannya untuk menguji pendapatnya dengan mengamati mulut istrinya. Aristoteles juga berkata bahwa bayi-bayi akan lebih sehat jika dibuahi waktu angin sedang bertiup di utara; bahwa gigitan seekor tikus kesturi lebih berbahaya dari gigitan seekor kuda, apalagi bila kesturi tersebut sedang hamil dan lain sebagainya. Terlepas dari pendapat-pendapat aneh tersebut, ahli-ahli pemikir klasik yang

\footnotetext{
${ }^{23}$ Mouly, George, "Perkembangan IImu", dalam Jujun S. Suria Sumantri, IImu dalam Perspektif, hlm. 87.
} 
tidak pernah memperhatikan binatang kecuali kucing dan anjing terus memuja Aristoteles. ${ }^{24}$ Sampai masa Renaissans, ajaran Aristoteles itu dianggap benar, relevan, memuaskan dan sekaligus cocok untuk semua tujuan, dan dengan demikian maka ilmu terjatuh kembali ke lembah yang penuh kemandulan tanpa guna.

Seperti yang telah disinggung oleh Aristoteles, bahwa kebaikan harus didasarkan pada intelektual atau ilmu dan moral. Dengan demikian, maka kebaikan akan memiliki landasan filosofis yang kuat sehingga dapat menjadikan pelakunya menjadi baik bila melakukannya sebagai kebiasaan, ${ }^{25}$ karena manusia merupakan pelaku yang bertanggung jawab terhadap tindakan. Dengan landasan moral dan intelektual yang baik yang melandasi suatu tindakan maka seseorang akan memiliki fondasi intelektual dan psikologis yang baik. ${ }^{26}$ Landasan prinsipil dari ilmu dan kebaikan itu adalah kebijaksanaan. Aristoteles mengindikasikan bahwa kebijaksanaan ilmu tertinggi yang menjadi objek filsafat, merupakan sebab dan prinsip-prinsip ilmu itu sendiri. ${ }^{27}$

Dalam sejarah filsafat, dan terkait dengan dialektika pemikiran para filosof, Aristoteles (384-322 S.M.) memiliki posisi yang cukup berpengaruh. Filosof Yunani yang lahir di Stagira ini, pada usia 18 tahun menjadi murid Plato di Akademi, menjadi guru di Athena selama 20 tahun. Kemudian menjadi guru pribadi Iskandar Agung (Alexander The Great). Selanjutnya mendirikan lembaga pendidikan sendiri yang dikenal sebagai Lyceum di Athena. Sumbangan pikirannya terhadap perkembangan ilmu pada zaman Yunani kuno meliputi hampir semua bidang: etika, biologi, fisika, politik, kesusasteraan, psikologi, metafisika, dan

\footnotetext{
${ }^{24}$ Ibid., hlm. 87-88.

${ }^{25}$ Aristoteles, hlm. 33.

${ }^{26}$ Ibid., hlm. 64-65.

27 Ibid., hlm. 7.
} 


\section{Refleksi Teoretis Etika Religius Syaikh Yusuf}

logika. Aristoteles diakui sebagai pelopor logika. Bidang pengetahuan yang menelaah struktur pikiran dan proses penalaran untuk mencapai kebenaran dinamakannya analitika atau yang berpangkal pada pernyataan yang benar, dan dialektika yang berpangkal pada pernyataan yang belum pasti kebenarannya. Ajaran-ajarannya ditulis dalam enam naskah yang kemudian dihimpun menjadi satu oleh para penganutnya dan diberi judul Organon. Pengetahuan dalam Organon kemudian oleh Alexander dari Aphrodisias dinamakan logika.

Pokok-pokok persoalan yang dibahas dalam karyanya adalah: Catagories, masalah konsep-konsep dasar yang dengannya pemikiran dilakukan; On Interpretation, masalah komposisi dan hubungan dari keterangan sebagai satuan pikiran; Prior Analytics, masalah inti dari logika silogisme kategorik dan modalitas dalam logika; Posterior Analytics, masalah penerapan silogistik dalam pembuktian ilmiah dan membicarakan metode pra anggapan serta proses definisi dan klasifikal; Topics, masalah membahas dialektika berdasarkan premis-premis yang boleh jadi benar; Sophistical Refutations, masalah pembahasan berbagai sesat pikir dan penyelesaiannya.

Selain itu, ada juga karyanya tentang metafisika. Teori Aristoteles mengenai sepuluh jenis keberadaan, yang dapat dijadikan pokok (untuk yang pertama) dan sebutan dalam suatu keterangan logika, yakni: Substance (benda), Quantity (besaran), Quality (sifat), Relation (hubungan), Place (tempat), Time (waktu), Posture, Attitude (sikap), Possesing (kemilikan), Doing Activity (kegiatan), dan Suffering Passivity (kesasaranan). Teori yang pertama dikemukakan oleh Aristoteles mengenai jenis-jenis sebutan (predicable) yang dapat dikenakan pada suatu pokok dan merumuskan suatu batasan dari pokok yang bersangkutan, ada empat buah, yakni: Genus (jenis), Differentia (ciri pembeda), Proprium (sifat khas), dan Accident (sifat sampiran). Penalaran 
Aristoteles ini kemudian disebut logika atau penalaran deduktif yang disebut juga logika tradisional yang selama berabad-abad merupakan satu-satunya yang dipergunakan dan dipelajari.

Pada permulaan abad XVII, Francis Bacon (1561-1626) berusaha mengembangkan logika baru dan filsafat ilmu. Logika yang dimaksud ialah logika induktif sebagai pengganti logika deduktif dari Aristoteles. Karyanya mengenai logika itu berjudul Novum Organum (1620) sebagai imbangan atau respons terhadap Organon dari Aristoteles. Bacon menekankan pengamatan dan metode empiris untuk diterapkan dalam filsafat. Pikiran manusia dalam filsafat dan ilmu harus dibebaskan dari kecenderungan atau sikap tertentu secara idol atau sesuatu yang dipuja, karena ini mengakibatkan kekeliruan atau kesesatan.

Pengkultusan akan mengakibatkan kekeliruan atau kesesatan dalam bidang ilmu dan filsafat. Ada empat macam kekeliruan dengan penamaan: idols of the cave, yakni kekeliruan-kekeliruan yang disebabkan oleh orangnya sendiri, misalnya prasangka pribadi atau cacat mental; idols of the market place, yakni berbagai kesalahan dan kelemahan dalam bahasa yang dipergunakan sebagai sarana komunikasi dari buah-buah pikiran; idols of the theatre, yakni kekeliruan-kekeliruan yang timbul dari berbagai azas kepercayaan dalam sistem filsafat dan kaidah-kaidah pembuktian yang salah; dan idols of the tribe, yakni berbagai kekeliruan yang berpangkal pada pemahaman dari manusia sendiri terhadap dunia kenyataan.

Novum Organum merupakan kritik kelemahan Organum, bahkan merupakan suatu pemberontakan terhadap cara berpikir filosof Yunani kuno tersebut. Menurut Bacon, logika saja tidak cukup untuk menemukan kebenaran itu sendiri, karena menurutnya kepelikan alam jauh lebih besar dari kepelikan argumen. Dalam hal ini logika dimulai dengan suatu anggapan menyimpang dari 


\section{Refleksi Teoretis Etika Religius Syaikh Yusuf}

keadaan sebenarnya. Lebih lanjut ia mengemukakan bahwa jika seseorang mengumpulkan keterangan yang cukup tentang sesuatu tanpa anggapan yang sebelumnya sudah terbentuk tentang hal tersebut, atau mencoba mempertahankan objektivitas yang sempurna, maka hubungan-hubungan yang terkait secara asasi akan muncul sebagai suatu kesimpulan bagi pengamat yang tekun. Metode ini disebut metode induktif. ${ }^{28}$

Metode induktif dari Bacon kemudian digantikan oleh metode induktif-deduktif dari Charles Darwin yang diakui sebagai pelopor penggabungan metode deduksi Aristoteles dengan metode induksi Bacon. Metode gabungan ini merupakan kegiatan beranting antara induksi dan deduksi, yang mana mula-mula seorang penyelidik mempergunakan metode induksi dalam menghubungkan antara pengamatan dan hipotesis, kemudian secara deduktif hipotesis dihubungkan dengan pengetahuan yang ada untuk melihat kecocokan dan implikasinya. Setelah melewat berbagai perubahan yang dinilai perlu, maka hipotesis kemudian diuji melalui serangkaian data yang dikumpulkan untuk mengetahui sah atau tidaknya hipotesis secara empiris. ${ }^{29}$

Pendekatan ini merupakan esensi dari metode keilmuan modern dan menandai kemajuan terakhir manusia dalam menjabarkan ilmu yang bersifat empiris dari tahap awal yaitu ilmu berkembang dari animisme. Antropologi dan sejarah manusia menunjukkan bahwa manusia pertama kali menerangkan gejalagejala seperti petir, banjir dan lain-lain sebagai perbuatan dewadewa. Mitologi kuno penuh dengan dewa dan dewi yang kelihatannnya memainkan peranan yang penting dalam kehidupan manusia primitif kemudian berubah menjadi manusia menyadari bahwa gejala alam dapat diterangkan sebab dan musababnya,

\footnotetext{
${ }^{28}$ Mouly, hlm. 88.

${ }^{29}$ Ibid., hlm. 90.
} 
suatu langkah yang penting yang menandai permulaan ilmu sebagai suatu pendekatan sistematis dalam pemecahan masalah. Perkembangan ke arah ini berlangsung lambat. Perkiraan yang kasar dan tidak sistematis juga secara lambat laun memberi jalan kepada observasi yang lebih sistematis dan kritis. Kemudian kepada pengujian hipotesis secara sistematis dan teliti di bawah kondisi yang dikontrol, meskipun hipotesis ini masih terpisahpisah, dan akhirnya paling tidak dalam beberapa bidang keilmuan, pengembangan teori yang menyatukan penemuan-penemuan yang terpisah tersebut ke dalam suatu struktur yang utuh dan formulasi pengujian secara sistematis dan teliti, telah terintegrasi yang diderivasi dari teori tertentu. Proses ini dibagi ke dalam dua tahap perkembangan yang saling bertautan.

Pertama, tingkat empiris, yang mana ilmu terdiri dari hubungan empiris yang ditemukan dalam berbagai gejala dalam bentuk-bentuk X menyebabkan Y tanpa mengetahui mengapa hal ini terjadi. Kedua, tingkat penjelasan teoretis yang mengembangkan suatu struktur teoretis yang tidak saja menerangkan hubungan empiris yang terpisah-pisah, namun juga mengintegrasikannya menjadi suatu pola yang berarti. Tingkat teoretis yang dicapai secara penuh oleh satu dalil disiplin-disiplin ilmu yang ada sekarang apalagi oleh ilmu-ilmu sosial. Tahapan tersebut adalah pengalaman, klarifikasi, kuantifikasi, penemuan hubunganhubungan dan perkiraan kebenaran. Dua langkah fundamental dalam perkembangan ilmu yaitu proses perkiraan kebenaran yang terus menerus dan proses pendefinisian kembali masalah ditinjau dari keberhasilan atau kegagalan perkiraan tersebut. ${ }^{30}$

Tingkat paling akhir dari ilmu adalah ilmu teoretis, yang mana hubungan dan gejala yang ditemukan dalam ilmu empiris diterang-

${ }^{30}$ Ibid., hlm. 96-98. 


\section{Refleksi Teoretis Etika Religius Syaikh Yusuf}

kan dengan dasar suatu kerangka pemikiran tentang sebab musabab sebagai langkah untuk meramalkan dan menentukan cara untuk mengontrol kegiatan agar hasil yang diharapkan dapat dicapai. Peralihan dari ilmu empiris ke ilmu teoretis adalah suatu langkah yang sukar. Kelihatannya relatif mudah untuk menemukan apa yang terjadi akan tetapi tidak sedemikian mudahnya jika harus menerangkan, mengapa hal itu terjadi? Hal ini nampak pada ilmuilmu sosial yang masih belum mempunyai penjelasan secara keilmuan untuk sebagian besar masalah. Sebagian ilmu pendidikan atau hampir seluruhnya merupakan ilmu empiris, namun kenyataannnya, masih harus juga menemukan lebih banyak lagi hubungan empiris yang terdapat dalam kelas. Mungkin kekurangan yang paling besar dalam ilmu ini adalah kegagalan untuk menyusun suatu kerangka teoretis. Hanya akhir-akhir ini terdapat kesadaran bahwa empirisme merupakan tahap keilmuan yang belum lengkap dan masih memerlukan orientasi yang lebih besar terhadap teori. ${ }^{31}$

Kaum rasionalisme memulai dengan suatu pernyataan yang sudah pasti. Aksioma dasar yang dipakai membangun sistem pemikirannnya diturunkan dari ide yang menurut anggapannnya adalah jelas, tegas dan pasti dalam pemikiran manusia. Pikiran manusia mempunyai kemampuan untuk mengetahui ide tersebut, namun manusia tidak menciptakannya, maupun tidak mempelajari melalui pengalaman. Ide tersebut kiranya sudah ada di sana sebagai bagian dari kenyataan dasar, dan pikiran manusia, karena ia terlihat dalam kenyataaan tersebut dan dalam pengertian inilah maka pikiran itu menalar. Kaum rasionalis berdalil bahwa, karena pikiran dapat memahami prinsip, maka prinsip itu harus ada, artinya prinsip itu harus benar dan nyata. Jika prinsip itu tidak ada, orang tidak mungkin akan menggambarkannya. Prinsip dianggap sebagai suatu a priori, karena itu prinsip tidak dikembang-

\footnotetext{
31 Ibid., hlm. 98.
} 
kan dari pengalaman bahkan sebaliknya. Pengalaman hanya dapat dimengerti bila ditinjau dari prinsip tersebut. ${ }^{22}$

Plato memberikan gambaran klasik dari rasionalisme, dengan menyatakan bahwa seseorang tidak dapat mengatakan apakah sebuah pernyataaan itu benar, kecuali kalau dia tahu sebelumnya bahwa itu benar. Kesimpulannya adalah bahwa manusia tidak mempelajari apapun, selain yang teringat dan apa yang ia ketahui. Semua prinsip-prinsip dasar dan bersifat umum sebelumnya sudah ada dalam pemikiran manusia. Menurut Plato pengetahuan adalah suatu penemuan selama proses pemikiran rasional yang teratur. ${ }^{33}$

Descartes menganggap bahwa pengetahuan memang dihasilkan oleh indera tetapi karena dia mengakui bahwa indera itu bisa menyesatkan, seperti dalam mimpi atau khayalan, maka dia terpaksa mengambil kesimpulan bahwa, data keinderaan tidak dapat diandalkan. Dia kemudian menguji kepercayaannya terhadap Tuhan Yang Maha Kuasa, tetapi di sini pun dia menemukan bahwa dia dapat membayangkan Tuhan yang mungkin bisa menipu manusia. Dalam kesungguhannya mencari dasar yang mempunyai kepastian mutlak ini, Descartes meragukan adanya surga dan dunia. Satu-satunya yang tidak diragukannya adalah eksistensi dirinya sendiri. Dia tidak meragukan lagi bahwa dia sedang ragu-ragu. Bahkan jika dia kemudian disesatkan dalam berpikir bahwa dia ada, dia berdalih bahwa penyesatan itu pun merupakan bukti bahwa seseorang yang sedang disesatkan. Kepastian Descartes ini diekspresikan dalam bahasa lain cogito ergo sum (aku berpikir maka aku ada). ${ }^{34}$

\footnotetext{
${ }^{32}$ Honer, Stanley M. dan Thomas C. Hunt, "Metode dalam Mencari Pengetahuan: Rasionalisme, Empirisme dan Metode Keilmuan", dalam Jujun S. Suria Sumantri, Ilmu dalam Perspektif, hlm. 99.

33 Ibid., hlm, 99-100.

${ }^{34}$ Ibid., hlm. 100.
} 


\section{Refleksi Teoretis Etika Religius Syaikh Yusuf}

Sejak Aristoteles, ada tradisi epistemologi yang kuat untuk mendasarkan diri kepada pengalaman manusia dan meninggalkan cita-cita untuk mencari pengetahuan yang mutlak. Doktrin empirisme merupakan contoh dari tradisi ini. Kaum empiris berargumen bahwa tidak beralasan untuk mencari pengetahuan mutlak yang mencakup semua segi, apalagi terdapat kekuatan yang dapat dikuasai untuk meningkatkan pengetahuan manusia yang meskipun bersifat lebih lambat namun lebih dapat diandalkan. Kaum empiris cukup puas dengan mengembangkan sebuah sistem pengetahuan yang mempunyai peluang yang besar untuk benar, meskipun kepastian mutlak itu tidak pernah dapat dijamin. ${ }^{35}$

Metode keilmuan adalah suatu cara dalam memperoleh pengetahuan. Suatu rangkaian prosedur tertentu yang harus diikuti untuk mendapatkan jawaban tertentu dari pernyataan tertentu pula. Mungkin epistemologi dari sebuah metode keilmuan akan lebih mudah dibicarakaan, jika mengarahkan perhatian kepada sebuah rumus yang mengatur langkah-langkah berpikir yang diatur dalam suatu urutan tertentu. Kerangka dasar prosedur ini dapat diuraikan dalam beberapa langkah, yaitu: sadar akan masalah dan perumusan masalah, pengamatan dan pengumpulan data yang relevan, penyusunan atau klasifikasi data, perumusan hipotesis, deduksi dari hipotesis dan tes dan pengujian kebenaran (verifikasi dari hipotesis). ${ }^{36}$

Ilmu dapat dianggap sebagai suatu sistem yang menghasilkan kebenaran dan seperti sistem-sistem yang lain, dia mempunyai komponen-komponen yang berhubungan satu sama lain. Komponen utama dari sistem ilmu diawali dengan perumusan masalah, pengamatan dan deskripsi, penjelasan, dan ramalan. ${ }^{37}$

\footnotetext{
${ }^{35}$ Ibid., hlm. 102.

36 Ibid., hlm. 105.

37 Sen, Peter R., "Struktur Ilmu", dalam Jujun S. Suria Sumantri, Ilmu dalam Perspektif, hlm. 111.
} 
Gejala sosial sesuatu yang lebih kompleks dibandingkan dengan gejala alami. Ahli-ahli ilmu alam, berhubungan dengan satu jenis gejala yakni gejala yang bersifat fisik. Gejala sosial juga mempunyai karakteristik fisik, namun diperlukan penjelasan lebih dalam untuk menerangkan gejala tersebut.

Ahli ilmu sosial harus mengatasi berbagai rintangan jika berharap membuat kemajuan, dalam menerangkan, meramalkan dan mengontrol kelakuan manusia. Kemajuan ini hanya dapat dicapai melalui penyelidikan yang gigih dan sabar. Kemajuan yang pesat yang dicapai ahli-ahli ilmu alam, menyebabkan ahli-ahli ilmu sosial harus memecahkan masalah kemanusiaan dengan tenaga baru. Perkembangan tenaga atom, transportasi berkecepatan tinggi, dan proses otomatisasi telah menyebabkan masalah sosial dan berbagai masalah ini harus dipecahkan bila masyarakat ingin maju.

Tiap-tiap bentuk adalah berbeda dari bentuk-bentuk lainnya, tidak terdapat dua bentuk yang identik, karena bila identik, maka tidak akan berjumlah dua. Konsekuensinya adalah bahwa semua gejala dan bukan semata-mata gejala ilmu-ilmu sosial adalah unik. Lebih lanjut dapat katakan bahwa jika anggapan mengenai keunikan adalah seperti yang diuraikan di atas, maka bukan hanya ilmuilmu sosial namun semua ilmu adalah tidak mungkin seperti setiap gejala atau bentuk sosial. Selaras dengan itu, maka argumentasi berdasarkan keunikan ini tidak mendukung sama sekali suatu pandangan bahwa harus terdapat perceraian yang radikal antara metodologi ilmu-ilmu sosial dan non-sosial. ${ }^{8}$

Dalam rangka memberikan dasar yang dapat diandalkan untuk menolak atau menerima hipotesis suatu kejadian yang sedang diselidiki, maka harus menyusun secara terpisah suatu gambaran sebelumnya tentang apa yang akan terjadi. Konsep yang

${ }^{38}$ Rudner, Richard S., "Perbedaaan antara Ilmu-ilmu Alam dan Ilmu-ilmu Sosial", dalam Jujun S. Suria Sumantri, Ilmu dalam Perspektif, hlm. 143. 


\section{Refleksi Teoretis Etika Religius Syaikh Yusuf}

lebih efektif dalam memberikan informasi adalah konsep perbandingan. Konsep ini berperan sebagai perantara antara konsep kualifikasi dan konsep kuantifikasi. ${ }^{39}$

Menurut filsafat Yunani kuno, bentuk tertinggi dari ilmu adalah kebijaksanaan. ${ }^{40}$ Bersama itu terlihat suatu sikap etika. Di zaman Yunani, etika dan politik saling berjalan erat, kebijaksanaan politik mengajarkan bagaimana manusia harus mengarahkan negara. Sebaliknya, ilmu tidak dapat mengubah apa-apa dari apa yang ingin atau sudah tercapai, ilmu tidak dirasakan sebagai suatu tantangan. Baru sejak abad ke-17, ilmu giat dikembangkan di Eropa, orang juga mencari apa tujuan sebenarnya dari ilmu. Fase yang sifatnya empiris rasional mulai bergeser ke fase eksperimental. Sifat progresif ini menunjukkan bahwa ilmu bukan sekadar tujuan bagi dirinya sendiri, melainkan sarana untuk mencapai sesuatu. Sebenarnya nilai dari ilmu terletak pada penerapannya. Ilmu mengabdi pada masyarakat sehingga ia menjadi sarana kemajuan. Boleh jadi orang mengatakan bahwa ilmu itu mengejar kebenaran dan kebenaran itu merupakan inti etika ilmu. ${ }^{4}$

Dalam hal ini, persoalan etika atau kebenaran dalam keilmuan, sudah menjadi perhatian sejak lama. Sejarah pergerakan dan perjuangan para ulama sebagaimana halnya, Syaikh Yusuf, dapat diidentifikasi sebagai sejarah pergerakan dan perjuangan menegakkan etika dengan berbagai varian konsep dan konstruksinya. Syaikh Yusuf menitikberatkan konstruksi etika dalam dimensi agama dalam hal ini tasawuf. Tasawuf sendiri merupakan inti dari etika yang diajarkan oleh para ulama yang berdakwah untuk menegakkan kebenaran. Keyakinan terhadap kekuatan etika ber-

\footnotetext{
${ }^{39}$ Ibid., hlm. 146.

${ }^{40}$ Aristoteles, hlm. 7.

${ }^{41}$ Daldjoeni, N., "Hubungan Etika dengan Ilmu", dalam Jujun S. Suria Sumantri, IImu dalam Perspektif, hlm. 234.
} 
dimensi tasawuf atau etika sufistik ini, dibuktikan dengan adanya pendirian yang kokoh dan teguh padanya (etika tersebut) juga adanya efek keberhasilan dalam perjalanan perjuangan menegakkan kebenaran.

Pada akhir abad XVIII dan abad XIX, terjadi rentetan pergolakan yang mengagumkan. Munculnya negara bangsa atau nation state modern yang ditandai gejolak revolusi-revolusi di tahun 1848, memperlihatkan berkuasanya gagasan-gagasan baru mengenai kebebasan, persamaan, persaudaraan. Amerika lahir, sebagai negara baru dengan konstitusi baru pula dan perang saudaranya yang berdarah mengakhiri perbudakan dalam peradaban Barat. Sementara itu Revolusi Industri membawa serta suatu restrukturisasi total dari masyarakat. ${ }^{42}$

Di tengah seluruh perubahan ini, orang mungkin mulai berpikir secara berbeda mengenai etika. Nilai-nilai lama, cara berpikir lama yang melayang-layang di atas, kini mendapat tantangan. Dengan latar belakang ini, argumen Bentham, yang membela konsep moralitas baru mempunyai pengaruh besar. Moralitas, menurut Bentham, bukanlah hanya soal menyenangkan Tuhan ataupun soal kesetiaan pada aturan-aturan abstrak. Moralitas tidak lain adalah suatu upaya untuk sedapat mungkin memperoleh kebahagiaan di dunia dengan prinsip utama yaitu utilitas. Utilitas menuntut agar setiap kali seseorang menghadapi pilihan dari tindakan-tindakan alternatif atau kebijakan sosial, dia dapat mengambil satu pilihan yang memiliki konsekuensi yang secara menyeluruh paling baik bagi setiap orang yang terlibat di dalamnya. Oleh karena itu, perilaku moral diartikan sebagai perilaku yang sesuai dengan nilai-nilai dasar yang dijunjung tinggi

${ }^{42}$ Rachels, James, The Elements of Moral Philosophy (terj.) (Yogyakarta: Kanisius, 2004), hlm.169. 


\section{Refleksi Teoretis Etika Religius Syaikh Yusuf}

oleh masyarakat manusia beradab, oleh karenanya ilmu merupakan bagian dari humanisasi. ${ }^{43}$

Dalam mencari kebenaran, ilmuwan senantiasa berusaha melengkapi dirinya dengan budi luhur, kebajikan, dan memanfaatkan peluang eksperimen, betapapun kecilnya menerobos tabir rahasia keilmuan. Budi luhur atau kebajikan ini misalnya kapasitas kerja keras, ketabahan atau kegigihan, ketekunan, kesetiaan pada tugas, keterbukaan untuk bekerja sama saling menghargai sesama ilmuwan serta hasil-hasil karyanya. Semua ini merupakan budi luhur dan kebajikan yang akan meningkatkan kemampuan manusia untuk berkomunikasi dengan sesamanya dan secara wajar dengan menunjukkan sikap dan prilaku moral terhadap sesamanya dan terhadap lingkungan alam di sekitarnya.

Dalam perspektif seperti ini, kata bermoral mengacu pada bagaimana suatu masyarakat yang berbudaya dan berperilaku, sedangkan beretika mengacu pada bagaimana seharusnya ia berperilaku. Etika memberikan nasehat-nasehat mengenai perilaku, yang biasanya dalam bentuk ungkapan, mutiara kata, pribahasa dan sebagainya yang menyiratkan, tetapi tidak menyatakan dengan tegas dan didambakan akan menuruti nasehat itu serta kemungkinan akibat-akibat buruk yang akan menimpa jika petuah itu dilanggar. 44

Tokoh-tokoh yang penting untuk diperhatikan pemikirannya, pada abad modern, yaitu abad IX dan XX, antara lain George Edward Moore, yang memiliki pengaruh yang cukup besar dalam bidang etika. Ia merumuskan beberapa proposisi yang sampai sekarang menantang para filosof moral. Arti utama pemikiran etis Moore terletak pada cara pendekatannya yang baru, yang mem-

\footnotetext{
${ }^{43}$ Wilardjo, L., "Ilmu dan Humaniora", dalam Jujun S. Suria Sumantri, IImu dalam Perspektif, hlm. 238.

${ }^{44}$ Ibid., hlm. 242.
} 
buka cakrawala persolaan baru bagi etika. Hal yang baru adalah bahwa ia memfokuskan perhatian pada logika argumentasi dan pada keabsahan bahasa yang dipakai dalam filsafat moral. Moore memasukkan analisis bahasa ke dalam etika dan menjadi seorang pendorong terpenting ke arah meta-etis yang khas bagi etika abad XX. Ia menjadi acuan filsafat abad XX dalam usaha mengatasi kerancuan dalam pemikiran etika. Di situlah letak kebesaran filsafat moral Moore. ${ }^{45}$

Etika Moore tersebut tertuang di dalam dua bukunya, yang pertama adalah Principia Ethica, terbit tahun 1903, dan yang kedua adalah Ethics, terbit tahun 1912. Garis-garis besar pemikiran dalam Principia Ethica adalah bahwa dalam etika terdapat tiga pertanyaaan dasar. Pertama, apa yang harus dilakukan? Kedua, apa yang bernilai? Ketiga, apa arti baik? Ketiga pertanyaan tersebut memiliki hubungan logis dari sudut kehidupan praktis. Pertanyaan yang langsung relevan adalah pertanyaan yang pertama. Manusia perlu mengetahui perbuatan mana yang benar dan mana yang salah. Pertanyaan ini termasuk wilayah bahasan etika normatif yang mencari prinsip-prinsip dasar kelakuan etis. ${ }^{46}$

Kelakuan yang benar adalah kelakuan yang paling tepat dalam melaksanakan apa yang baik. Maka secara logis, pertanyaan yang pertama mengandaikan jawaban atas pertanyaan yang kedua. Manusia harus mengetahui terlebih dahulu apa yang baik, baru dapat mempertanyakan tindakan mana yang paling cocok untuk mencapai yang baik itu. Dalam bahasa etika, etika normatif mengandaikan etika nilai. Tetapi, untuk mengetahui apa yang bernilai, manusia harus mengetahui lebih dahulu nilai itu sendiri apa. Dalam bahasa Moore, untuk mengetahui apa yang baik (the good) harus

\footnotetext{
${ }^{45}$ Suseno, Franz Magniz, Etika Dasar Masalah-Masalah Pokok Filsafat Moral, 9Yogyakarta: Kanisius, 1987), hlm. 11.

46 Ibid., hlm. 12-13.
} 


\section{Refleksi Teoretis Etika Religius Syaikh Yusuf}

mengetahui terlebih dahulu kata baik. Jadi, jelaslah bahwa pertanyaan etika yang paling mendasar adalah masalah hakikat kebaikan. Menurut Moore, perbuatan yang benar adalah perbuatan yang menghasilkan sebanyak mungkin realitas yang baik. ${ }^{47}$

Dengan demikian, naturalisme adalah ciri etis dari etika normatif. Bahwa pernyataan tentang kewajiban atau kebaikan diterjemahkan ke dalam pernyataan tentang sebuah kenyataan atau sebuah realitas. Naturalisme menerjemahkan sikap normatif ke dalam sikap deskriptif atau yang mengharuskan ke dalam yang menjelaskan, yang das sollen ke dalam yang das sein. ${ }^{48}$

Berdasarkan konstruksi Moore, maka teori-teori etika yang bercirikan naturalistik dapat dibagi ke dalam dua kelompok. Pertama naturalisme etis, yang dalam arti sempit dapat disamakan dengan sebuah fakta atau keadaan alami, dan kedua etika-etika metafisik yang menyamakan sebuah realitas normatif atau nilai dengan sebuah keadaan non-normatif faktual, entah fisik atau metafisik. Menurut naturalisme etis, penilaian moral dan pernyataan normatif, bukan sebuah kelas atau pernyataan tersendiri di luar pernyataan faktual, melainkan termasuk pernyataan faktual, yakni pernyataan tentang ada tidaknya sebuah realitas. Kesamaan semua teori yang termasuk naturalisme etis adalah menyangkal adanya penilaian moral sebagai kelompok pernyataan tersendiri. Kebaikan moral dapat dibuktikan dengan bantuan ilmu-ilmu sosial, psikologi atau dalam hal etika yaitu, metafisika dan teologi. Hal yang baik berarti terdapat sifat tertentu, di sinilah ilmu yang dapat meneliti ada tidaknya sifat-sifat itu dan membuktikan apakah sesuatu itu baik.

Tokoh pemikir etika yang selanjutnya adalah Max Scheler, (lahir 1874) yang mengembangkan filsafat etika tentang manusia,

\footnotetext{
47 Ibid.

${ }^{48}$ Suseno (2000), hlm. 18.
} 
persona tentang agama dan tentang Tuhan. Etika Scheler berakar dalam sebuah pengalaman dasar, pengalaman akan nilai-nilai formalisme etika. Buku yang memuat etika nilai dan yang menjadi dasar Scheler adalah Der Formalismus in der Ethik und die Materiale Wertethik. Neuer Versuch der Grundlegung eines Ethischen Personalismus. ${ }^{49}$

Scheler mengkritisi pandangan Kant tentang etika. Bila Kant bertolak dari anggapan bahwa kewajiban moral bersifat mutlak atau imperatif, artinya tidak dapat ditawar-tawar, dari pengandaian itu ia menarik sebuah kesimpulan prinsipil. Moralitas sebuah tindakan, tidak akan tergantung dari tujuan atau nilai yang mau dicapai, karena tujuan dan nilai selalu tergantung dari situasi dan kondisi, jadi tidak mutlak. ${ }^{50}$ Jadi bukan materi kewajiban yang menentukan kadar moralnya, tetapi bentuknya atau formalnya sebagai suatu kewajiban, jadi etika Kant berwujud formalisme. ${ }^{51}$

Menurut Scheler, dengan formalismenya Kant justru tidak menangkap hakikat moralitas yang sebenarnya. Sebuah tindakan bernilai secara moral, bukan karena merupakan kewajiban melainkan karena bernilai secara moral. Nilai mendahului kewajiban. Inti moralitas bukan kesediaan untuk memenuhi kewajiban, melainkan kesediaan untuk merealisasikan apa yang bernilai. Mengusahakan nilai-nilai moral sebenarnya tidak perlu diperintahkan karena manusia dengan sendirinya tertarik oleh apa yang bernilai. Maka bukan kewajiban melainkan nilai yang menjadi pusat moralitas.

Nilai-nilai tidak dipikirkan atau diketahui tetapi dirasakan. Merasa menurut Scheler, merupakan suatu kemampuan tanpa

\footnotetext{
${ }^{49}$ Ibid., hlm. 33.

${ }^{50}$ Kant, Immanuel, Critique of Practical Reason (terj.) (Yogyakarta: Pustaka Pelajar, 2005).

${ }^{51}$ Suseno (2000), hlm. 34.
} 


\section{Refleksi Teoretis Etika Religius Syaikh Yusuf}

pengamatan maupun pengalaman manusia yang khas atau a priori emosional atau perasaan nilai intensional. Dalam hal ini, Scheler juga mengembangkan filsafatnya tentang persona dan tentang cinta. Kata persona menurut Scheler mengungkapkan keterbukaan manusia terhadap alam nilai. Dia menolak pandangan Aristoteles tentang persona, sebagai substansi yang menjadi subjek berbagai actus. Persona seluruhnya terwujud dalam rentangan terhadap nilai-nilai, tidak ada dasar substansial di bawah rentangan itu. Makin persona terbuka terhadap alam nilai, makin ditantang untuk menentukan sikap dan tindakannya, makin berkembang dan berubah, sekaligus makin mewujudkan identitasnya sendiri..$^{2}$

Secara garis besar, filsafat etika Scheler kemudian dibagi menjadi empat model atau gugus nilai. Gugus nilai pertama dan paling rendah adalah segala nilai dalam dimensi yang menyenangkan dan tidak menyenangkan, dalam arti perasaan badani, sehat atau sakit. Gugus yang kedua adalah nilai-nilai yang berkenaan dengan perasaan vital yang berkaitan bukan dengan fungsifungsi inderawi tertentu, melainkan dengan kehidupan dalam kebutuhannnya. Nilai-nilai ini tersebar di sekitar yang luhur dan yang kasar dalam arti kesehatan fisik, dan yang lemah misalnya ringkih, sakit dan lain sebagainya. Gugus yang ketiga adalah nilainilai rohani. Nilai-nilai itu tidak lagi tergantung dari dimensi ketubuhan. Scheler mencatat, bahwa orang bersedia mengorbankan nilai-nilai kehidupan demi nilai-nilai rohani. Hal ini terbagi tiga, pertama adalah nilai estetis mengenai yang indah dan yang jelek, yang kedua adalah nilai benar dan tidak benar, dan yang ketiga adalah nilai pengetahuan murni. Gugus keempat yang tertinggi adalah nilai-nilai di sekitar daerah kudus dan yang profan, termasuk di sini adalah kebahagiaan religius. ${ }^{53}$

\footnotetext{
52 Ibid., hlm. 34-35.

${ }^{53}$ Ibid., hlm. 40-41.
} 
Selanjutnya adalah etika emotivistik yang dikembangkan oleh A.J. Ayer, lahir tahun 1910. Filosof Inggris ini termasuk tokoh aliran empirisme ilmiah atau positivisme logis. Menurut aliran ini, filsafat ditafsirkan sebagai analisa logis dan proses penjelasan dari bahasa biasa. Pernyataan umum dalam ilmu terikat dalam asas verifikasi, sebagaimana dalam karyanya, The Foundations of Empirical Knowledge (1940) Sebagai penganut positivisme logis, Ayer menyangkal keabsahan penilaian moral. Menurut Ayer, perasaan moral termasuk bidang psikologi dan anjuran moral bidang sosiologi. Etika normatif mempertanyakan pembenaran pernyataan-pernyataan moral seperti itu. Sesuai dengan keyakinan positivisme, Ayer menyangkal bahwa pernyataan moral menyatakan sesuatu apapun dan oleh karena itu juga tidak masuk akal untuk mempertanyakan pembenarannya. Satu-satunya tugas etika adalah dengan pendekatan analisis logis terhadap bahasa moral yang bersifat meta-etika. Jadi Ayer mengakui meta-etika, bahwa perbedaan dalam penilaian itu sebenarnya bila semua fakta tersebut sudah tercapai kesamaan pendapat, tinggal argumen yang dapat diajukan untuk mendukung suatu penilaian. Hal yang menunjukkan bahwa, sebenarnya bukan penilaian melainkan orang mempunyai perasaan berbeda-beda terhadap suatu permasalahan. Ayer bertolak dari pengandaian bahwa apa yang tidak dapat dibuktikan dengan sebuah argumen atau verifikasi empiris tidak mempunyai arti. ${ }^{54}$

Tokoh selanjutnya adalah Jean-Paul Sartre, lahir tahun 1905, yang terkenal dengan filsafat eksistensialismenya. Manusia senantiasa sadar tentang perbedaan dirinya dengan bentuk-bentuk kehidupan lainnya. Akan tetapi, apanya yang berbeda? Apa pula maksudnya berada? Salah satu hal terpenting yang membedakan kehidupan manusia adalah menyadari keberadaannya, eksistensi-

\footnotetext{
${ }^{54}$ Ibid., hlm. 57-61.
} 


\section{Refleksi Teoretis Etika Religius Syaikh Yusuf}

nya serta mempertanyakan keberadaannya. Manusia tidak hanya ada, ia memahami bahwa ia ada, dan menyadari bahwa keberadaannya suatu saat akan berakhir dengan kematian atau keberakhiran. ${ }^{55}$

Secara falsafati, eksistensialisme pada dasarnya adalah protes terhadap pandangan bahwa manusia adalah benda, serta tuntutan agar eksistensi personal seseorang harus benar-benar diperhatikan secara serius. Pemikirannya dituangkan dalam salah satu karya besarnya, Being and Nothingness, yang menelaah tentang cara berada, yaitu ada tanpa beban, sadar tanpa isi, ada Ilahi atau ada di sisi Tuhan. Sartre menyebut pemikirannnya sebagai eksistensialisme karena pusatnya adalah eksistensi. Manusia itu sadar bahwa ia berada, ia bereksistensi karena dia menyadari diri berhadapan dengan kekosongan. Eksistensi manusia dalam hubungannya dengan etika ditentukan oleh dua dimensi yaitu yang berada pada dirinya sendiri, dan yang berada di luar dirinya sendiri. Dalam karangan Sartre, L-Eksistentialisme est un Humanisme, tahun 1946, bahwa dalam pilihan-pilihannya, manusia sendiri tidak hanya menciptakan nilai-nilainya melainkan ia juga mengikat diri. Ia menjadi diri, Ia mendapat bentuk, dan hakikatnya. Keputusan itu berarti bahwa ia menjadi ini atau itu, jadi esensinya terwujud. Keputusan-keputusannya menunjukkan siapa dia. Manusia dapat mengatakan, melalui pilihan-pilihannya, manusia mewujudkan karakternya. Lama-kelamaan kelihatan orang macam apa dia, dalam kaitannya dengan tindakan yang beretika. ${ }^{56}$

Pandangan filsafat selanjutnya yang berkenaan dengan etika tanggung jawab atas orang lain adalah filosof Emmanuel Levinas (lahir 1906). Levinas tidak tertarik pada pertanyaan-pertanyaan

\footnotetext{
${ }^{55}$ Martin, O.P., Vincent, Filsafat Eksistensialisme: Kerkegaard, Sartre, Camus, (Yogyakarta: Pustaka Pelajar, 2003).

${ }^{56}$ Suseno (2000), hlm. 77-73.
} 
rutin etika filosofis. Teori yang dikembangkan adalah mengapa manusia dapat merasa tertantang untuk bersikap baik terhadap sesama, mengapa dapat memilih, antara sikap bertanggung jawab atasnya atau tidak. Bila banyak filosof-filosof moral atau etika pada umumnya mencari prinsip-prinsip yang menjadi dasar normanorma moral, maka Levinas lain dengan itu. Levinas ingin memperlihatkan bahwa pembentukan identitas berdasarkan sebuah peristiwa awal yang terulang setiap kali bertemu dengan orang lain. Setiap kali bertemu dengan orang lain, terjadi sesuatu yang mendasar, dan menjadi bertanggung jawab atasnya. Tanggung jawab awal mendahului segala sikap, yang merupakan kenyataan paling dasar dalam kesadaran. Itulah intuisi inti dalam filsafat Levinas. ${ }^{57}$

Menurut Levinas, etika primordial adalah etika tanggung jawab, yang juga merupakan peristiwa ketika berhadapan dengan orang lain. Dalam situasi ini manusia bertanggung jawab total terhadap orang lain. Akan tetapi, manusia tidak pernah dapat memberikan diri secara total kepada seseorang, karena ada banyak orang lain. Oleh karena itu, etika dengan orang lain berhubungan dengan keadilan. Levinas menegaskan bahwa kemungkinan untuk bersikap adil, dengan sebaik-baiknya memperbantukan diri kepada orang-orang lain, serta keadilan melalui lembaga-lembaga yang terdapat dalam masyarakat, adalah primordial manusia. ${ }^{8}$ Etika Levinas dapat dikatakan etika penebusan, bukan etika dalam arti filosofis biasa. Etikanya adalah etika fundamental, dalam arti bahwa hal yang paling pertama dalam eksistensi adalah tanggung jawab terhadap sesama, jadi sikapnya positif dan tidak negatif. Panggilan untuk menjadi solider, sebagai penebus bagi sesama. Ringkasnya menurut Levinas, etika tertinggi dalam kaitannya

57 Ibid., hlm. 87-89.

58 Ibid., hlm. 103-104. 


\section{Refleksi Teoretis Etika Religius Syaikh Yusuf}

dengan tugas manusia adalah menjadi penjaga sesama saudara manusia. ${ }^{59}$

Selanjutnya dalam perkembangan filsafat etika abad XX, muncul suatu aliran etika yang disebut etika situasi, dengan tokohnya Joseph Fletcher. Dalam filsafat, etika situasi tidak banyak mendapat perhatian karena dikembangkan oleh kaum teolog. Tetapi dalam cara menilai kelakuan, etika situasi jauh lebih berpengaruh daripada semua etika lain yang diperkenalkan. Etika situasi berhasil mendorong teologi moral Kristiani ke arah pembaharuan yang mendalam dalam beberapa tahun terakhir ini. Secara singkat, etika situasi mengatakan bahwa, apa yang wajib dilakukan oleh seseorang dalam situasi konkret, tidak dapat disimpulkan dari suatu hukum moral umum, tetapi harus diputuskan secara bebas oleh orang yang bersangkutan. Etika situasi menjunjung tinggi otonomi moral individu dan menolak ketaatan begitu saja terhadap suatu hukum moral sebagai heteronomi. Tidak ada perbuatan yang pada dirinya baik atau jahat, semuanya tergantung dari situasi. ${ }^{60}$

Etika situasi, dimaknai sebagai usaha untuk menerjemahkan pokok keyakinan eksistensialisme ke dalam filsafat dan teologi moral. Sumber kedua dari filsafat etika situasi adalah personalisme. Anggapan dasar etika situasi adalah bahwa kualitas moral sebuah tindakan tergantung dari situasi. Dengan kata lain, dalam setiap situasi, orang yang bersangkutan harus memutuskan secara otonom apa yang akan dilakukannnya, tidak ada hukum moral yang berhak begitu saja menuntut untuk ditaati. ${ }^{61}$ Menurut Fletcher, etika memakai empat prinsip kerja: pragmatisme, relativisme, positivisme, dan personalisme. Menurut pragmatisme, yang baik

\footnotetext{
${ }^{59}$ Ibid., hlm. 106.

${ }^{60}$ Ibid., hlm. 111.

${ }^{61}$ Ibid., hlm. 112-114.
} 
adalah apa yang jalan, yang berguna dan yang memuaskan. Yang menentukan kualitas moral adalah tindakan, bukan diukur dari aturan terpenuhi atau tidak, melainkan apakah hasil nyata positif tercapai atau tidak. Etika situasi mengandung relativistik, karena semua hukum dan aturan moral dianggap berlaku jika mendukung cinta kasih. Hukum moral tidak boleh menjadi tujuan nya sendiri. Hukum hanya bernilai sejauh melayani cinta kasih. Bukan otoritas melainkan pengalaman, bukan kekakuan suatu aturan melainkan kebebasan adalah khas bagi etika situasi. Manusia selalu diperintah untuk bertindak sesuai dengan cinta kasih, tetapi bagaimana melaksanakannya tergantung dari penilaian manusia tentang situasi yang bertanggung jawab. Etika situasi mengandung positivisme karena menolak keberlakuan hukum kodrat yang tinggal dilaksanakan. Penilaian moral merupakan keputusan, bukan kesimpulan. Tidak ada hukum kodrat yang tinggal diterapkan pada situasi konkret begitu saja. Melainkan orang memutuskan dengan bebas, berdasarkan cinta kasih sebagai hukum satu-satunya. Etika situasi menganut personalisme, berarti bahwa ia menolak adanya nilai-nilai intrinsik maupun perbuatan-perbuatan yang pada dirinya sendiri baik atau buruk. Yang bernilai pada dirinya sendiri hanyalah manusia, eksistensinya, perkembangannya, keadaan baiknya. Itulah yang diajarkan oleh cinta kasih. Mencintai berarti mendukung sesama dalam eksistensinya dan dalam perkembangannya, mendukung agar ia berada dalam keadaan baik. Di luar manusia tidak ada nilai dan tidak ada hukum yang mempunyai prioritas terhadap kepentingan kebaikan persona. Hukum itu demi manusia dan bukan manusia demi hukum. Etika situasi tidak bertanya apa yang baik, melainkan bagaimana berbuat baik bagi siapa, ia adalah etika keputusan, etika membuat keputusan lebih daripada mencari apa yang harus dilakukan dalam sebuah pegangan peraturan-peraturan. ${ }^{62}$

62 Ibid., hlm. 117. 


\section{Refleksi Teoretis Etika Religius Syaikh Yusuf}

Selanjutnya terdapat pula pandangan filsafat yang membahas tentang behaviorisme, atau sikap atau prilaku dalam etika, yang terkenal dicetuskan oleh, Byrus Frederic Skinner. Menurut Skinner, sebenarnya kelakuan manusia selalu merupakan jawaban atas rangsangan dari lingkungan alam dan sosialnya. Dalam hubungan ini, Skinner menegaskan bahwa ia tidak menyangkal adanya dimensi batin. Hal yang dipegangnya adalah bahwa behaviorisme metodologis yang membatasi diri pada apa yang dapat diamati secara umum. Proses-proses mental bisa saja ada, tetapi dikeluarkan dari pertimbangan ilmiah karena sifat batin. Maka kalau sekarang mau merekayasa kelakuan manusia secara ilmiah, menghapus ilusi manusia otonom, bukan manusia itu sendiri. Perbedaannya hanya, bahwa dulu manusia ditentukan oleh faktorfaktor lingkungan yang acak dan tidak diketahui, sedangkan sekarang lingkungan itu dirancang secara rasional. Lingkungan yang mengontrol manusia, semakin akan dikontrol oleh manusia sendiri. Skinner berpendapat, manusia bersedia memakai kemungkinan teknologi kelakuan untuk merancang unsur-unsur budaya masa datang dan mendukung suatu kelakuan yang diharapkan. ${ }^{63}$

Tokoh pemikir etika yang penting yang lain adalah, Kohlberg. Melalui penelitiannya, Kohlberg menemukan bahwa perkembangan kemampuan anak untuk memberikan penilaian moral menunjukkan adanya satu struktur tetap. Psikoanalisis selalu fokus pada isi penilaian moral, bahwa tidak boleh membunuh, tidak boleh korupsi, yang lalu dijadikan sebagai pembatinan norma-norma lingkungan. Tetapi penelitian Kohlberg, menunjukkan bahwa yang lebih relevan bukan isi jawaban, melainkan pendasarannya. Misalnya atas pertimbangan apa anak menyetujui dokter memberikan obat yang mematikan? Pertimbangan-pertimbangan yang dikemukakan ternyata menunjukkan pola-pola tertentu yang mempunyai

${ }^{63}$ Ibid., hlm. 142. Lihat Kohlberg (1987), hlm. 1-17. 
suatu struktur kognitif. Berdasarkan pengertian tertentu, orang akan mampu mempertanggungjawabkannnya.

Hasil penelitian Kohlberg, dapat dirumuskan sebagai berikut: Dalam perkembangan, kesadaran moral anak melalui beberapa tahap, tepatnya enam tahap. Tahap-tahap itu termasuk dalam tiga tingkat atau level. Kesadaran moral tingkat pra konvensional, tingkat konvensional dan tingkat pasca konvensional. Tahap-tahap itu bersifat invarian, universal dan transkultural. Artinya, di semua lingkungan budaya anak akan mulai di tahap satu lalu ke tahap dua dan seterusnya ke tahap mana anak akan sampai, tidak pasti melainkan tergantung dari lingkungan sosial budaya dan juga dari kemampuan intelektual individual. Tetapi di manapun anak sampai ke tahap lima misalnya, ia mesti sebelumnya melalui tahap 1,2,3,4 dan dalam urutan itu. ${ }^{64}$

Berkaitan dengan etika masa depan dan tanggung jawab, muncul pula aliran etika masa depan dalam kaitannya dengan tanggung jawab. Tokoh aliran ini adalah Hans Jonas, tahun 1903. Pada Hans Jonas, etika tanggung jawab mendapat sebuah konteks dan urgensi yang baru. Umat manusia mulai menyadari sesuatu yang tidak pernah terpikirkan sebelumnya dan karena itu tidak pernah perlu ditangani oleh etika, yaitu bahwa ia dalam memakai teknologi untuk semakin menguasai alam, dapat sekaligus menghancurkan dasar-dasar alami darinya ia hidup. Kalau dulu cukup bertanya, apakah suatu tindakan itu baik atau sekurang-kurangnya tidak jahat, dan apakah akibat-akibatnya dapat dibenarkan, maka sekarang, kalau pun perbuatan itu baik dan akibatnya dapat dibenarkan pula, tindakan yang sama di masa depan dapat saja menghancurkan ekosistem bumi dan karena itu tidak dapat dibenarkan. Inilah krisis peradaban teknis industrial. ${ }^{65}$

\footnotetext{
${ }^{64}$ Suseno (2000), hlm. 156.

${ }^{65}$ Ibid., hlm. 174-175.
} 


\section{Refleksi Teoretis Etika Religius Syaikh Yusuf}

Situasi ini menurut Jonas hanya dapat dihadapi dengan sebuah etika gaya baru. Titik tolaknya adalah kesadaran apokaliptik sebuah heuristika ketakutan. Ketakutan terhadap kemungkinan mengerikan tersebut, filsafat moral mampu mempertanyakan apa yang sebenarnya harus dilakukan. Berhadapan dengan perasaan takut, ada suatu kewajiban etika masa depan yang jelas. Di sini manusia harus memakai fantasi dan membayangkan akibat-akibat jangka jauh dinamika peradaban teknologi sekarang. Selanjutnya adalah membangun perasaaan yang sesuai dengan apa yang dibayangkan. Menurut Jonas, untuk praktik moral dan politik perumusan prinsip tanggung jawab barangkali sudah cukup. Tetapi, bagi etika pekerjaannya baru dimulai. Prinsip tanggung jawab baru terjamin, apabila etika dapat dengan meyakinkan menjawab pertanyaan, apakah manusia memang wajib bertanggung jawab atas masa depannya dan masa depan ekosistem bumi. ${ }^{66}$

Kritik ideologi yang dilontarkan humanisme sekuler ini, menantang agama-agama untuk menawarkan kekhasannya. Apakah agama memperkaya etika? Agama tidaklah memperkaya etika, namun agama menspesifikasi tindakan etis, karena agama dalam etika menjadi penjaga kekhasan individu. Agama menempatkan etika di dalam komunitas konkret, bukan abstrak seperti dalam konsep kemanusiaan dengan organisasi, tradisi, ritus, institusi, teologi dan individu-individu anggotanya.

Akan tetapi, aspek konkret itu bagai pedang bermata dua. Di satu pihak, agama menjadi perekat sosial dan menjadi struktur simbolis dari ingatan kolektif pemeluknya. Ingatan kolektif terhadap peristiwa pewahyuan yang menjadi raison d'etre kelompok sosial tersebut. Di lain pihak identitas konkret agama

66 Ibid., hlm. 175-177. 
bisa menimbulkan masalah karena agama juga berperan sebagai ideologi, artinya memberi kerangka penafsiran untuk memahami dunia dan dalam pemaknaan hubungan-hubungan sosial. Pemaknaan atau penafsiran cenderung menyembunyikan kepentingan-kepentingan. Penyembunyian kepentingan ini tidak bisa dilepaskan dari upaya integrasi dan pembenaran dominasi. ${ }^{67}$

Apa yang ditafsirkan dan mendapat pembenaran dari agama adalah, hubungan kekuasaan. Setiap tindakan dan setiap kekuasaan selalu mencari legitimasi. Kekuasaan menuntut lebih dari keyakinan yang dimiliki. Untuk mengisi kekurangannya, agama berperan sebagai sistem pembenaran dominasi. Apabila identitas agama terancam, sama saja dengan mengancam status sosial, stabilitas dan keberadaan pemeluknya. Maka siapa pun yang dianggap mengancam akan dilawan bahkan sampai pada pembunuhan. Hal ini karena tekanan agama yang berlebihan pada yang benar dan yang baik. ${ }^{68}$

Dalam perdebatan etika religius, yang indah sering tersingkir oleh fokus pada yang baik dan yang benar, tetapi bukan sama sekali diabaikan. Perhatian pada orientasi estetis kesadaran mengundang kehati-hatian untuk tidak mengidentifikasi kesadaran estetis dengan kesadaran religius. Yang terakhir ini menanggung penderitaan individu-individu konkret, sedangkan kesadaran estetis ingin membidik tipe-tipe tertentu karena seni tidak mengenal kepedihan pada dirinya sendiri. Seni hanya melihat wajah buruk atau indah atau materi ungkapannya. Dalam estetika, agama menampakkan diri melalui kemampuannya membangkitkan perasaan khas yang tidak dapat direduksi menjadi perasaan estetis, tetapi berubah dalam rasa dan belas kasih. Perasaan religius ini langsung terkait dengan ekspresi tentang Tuhan karena meru-

\footnotetext{
${ }^{67}$ Haryatmoko (2003), hlm. 84.

68 Ibid., hlm. 85.
} 


\section{Refleksi Teoretis Etika Religius Syaikh Yusuf}

pakan ungkapan penantian keselamatan dan pembebasan. Doa menemukan artinya, karena pengungkapan penantian pembebasan itu. Dengan demikian, konvergensi antara estetika dan agama terletak pada doa dan terutama dalam mistisisme yang mendambakan suatu partisipasi pada ketidakterbatasan Ilahi.

Agama konkret cenderung menerima hukum pemisahan yang mendasari hubungan antara Tuhan dan manusia. Pemisahan ini tanpa disadari oleh para pemeluknya ingin disatukan, yaitu ketika manusia melakukan kekerasan dengan mengatasnamakan Tuhan.. Hal ini dinilai sangat tidak etis dipandang dari kacamata umum, cendekiawan atau para pendakwah agama mana pun.

Nilai menjadi penting dalam suatu tindakan, karena nilai merupakan standar baku yang dengan itu manusia dipandang penting. Semua manusia berbuat, semua manusia berusaha untuk mengubah keadaan yang tidak memuaskan menjadi keadaan yang lebih memuaskan. Semua manusia mengusahakan tujuan tertentu. Inilah mengapa membutuhkan pengetahuan-pengetahuan tentang kebenaran faktual. Pengetahuan-pengetahuan tersebut membantu untuk memilih sarana yang paling efektif dan tepat untuk mencapai tujuan. Nilai ilmu terutama bersifat instrumental meskipun pengetahuan dan pencarian pengetahuan juga bernilai secara instrinsik. Namun, tujuan akhir manusia tidak perlu dibenarkan oleh ilmu karena bagian yang lebih besar sebagai sarana untuk mengejar tujuan yang melampaui dirinya sendiri. Ilmu harus dibenarkan oleh nilai dan bukan malah nilai yang dibenarkan oleh ilmu. ${ }^{69}$

Sehubungan dengan etika religius dalam kaitannya dengan keberadaan Tuhan, dewasa ini perdebatan modern mengenai eksistensi Tuhan telah bergeser. Kaum filosof tidak lagi mempertahankan pandangan dunia Abad Pertengahan. Aquinas yakin

${ }^{69}$ Hazlitt, Henry, The Foundation of Morality (terj.) (Jakarta: Pustaka Pelajar, 2003), hlm. 206. 
bahwa sekarang terdapat jurang yang jelas antara bahasa teologis dan bahasa ilmiah yang sangat diupayakan untuk dijembatani oleh banyak pemikir. Banyak teolog modern berpendapat bahwa kiranya tidak dapat diberikan suatu demonstrasi ilmiah mengenai eksistensi Allah, merujuk pada iman terdahulu sebagai landasan penalarannya. Kenyataan-kenyataannya banyak teolog modern telah sampai pada pertanyaan, apa sebenarnya arti kata Allah, dan berada. Sebab, bila Allah ada, bagaimana Dia berada. Pengertian tradisional mengenai Allah, sebagai Bapa personal, penuh kasih, dan pencipta yang aktif di dunia, yang ingin mencintai dan menyelamatkan manusia yang terancam.

Paul Tillich (1886-1965), salah seorang teolog modern yang cukup berpengaruh menyatakan pemahamannya, bahwa iman sebagai perhatian utama. Teologi Tillich bersifat eksistensial, dan ia mengklaim bahwa karena Allah tidak dapat dikatakan berada dalam cara yang sama dengan benda-benda lain di dunia, maka dalam arti sebenarnya, Allah tidak dapat dikatakan berada sama sekali. Tillich percaya bahwa penyajian Allah di dalam kitab suci merupakan gambar dari pengalaman utama manusiawi. Akibatnya, ia menolak iman seorang yang bersifat pribadi. Sebaliknya, Allah adalah dasar dari keberadaan. Mengapa kesadaran akan keberadaan Allah menjadi penting dalam kaitannya dengan filsafat etika religius, karena dengan menyadari adanya Sang Pencipta, manusia dapat menyadari hakikat eksistensi dirinya serta tugas yang diembannya dalam hidup ini.

Hakikat adalah hal terpenting dari sesuatu yang terdiri dari atas pengertian yang sifatnya abstrak. Abstrak berarti tidak konkret atau tidak dapat dihayati atau diamati dengan pancaindra. Sebagai contoh, manusia sebagai makhluk hidup dapat dihayati dengan panca indera apabila yang diamati adalah jasmani atau fisiknya. Sebaliknya, bila yang dibayangkan adalah jiwa atau roh, maka menjadi abstrak. Namun, semuanya bersifat hakiki, karena jiwa 


\section{Refleksi Teoretis Etika Religius Syaikh Yusuf}

merupakan hal yang pokok dalam kehidupan manusia, jiwa manusia dapat mengendalikan jasmaninya. Bila seseorang sedang malas maka ia enggan berbuat sesuatu. Namun, bila ia bersemangat maka ia akan bersemangat pula untuk melakukan sesuatu itu sampai berhasil. Hal penting yang harus diperhatikan adalah bahwa, pada dasarnya antara jiwa dan raga mempunyai hubungan timbal balik yang saling mempengaruhi. ${ }^{70}$

Berkaitan dengan etika religius, aspek epistemologi yang perlu diperhatikan dalam pendidikan serta pengajaran adalah pengetahuan yang hendaknya bersifat ideal dan spiritual, yang dapat menuntun kehidupan manusia pada kehidupan yang lebih mulia. Pengetahuan semacam itu tidak semata-mata terikat oleh hal-hal yang bersifat spiritual. Orang mengetahui bahwa komposisi makanan terdiri dari berbagai gizi, tetapi saat memakannya perlu disertai rasa syukur bahwa makanan itu adalah karunia Tuhan dan bila telah dimakan diharapkan dapat mencerdaskan pikiran untuk mencapai hal-hal yang baik bagi kehidupan.

Hal gizi dan kebersyukuran tentang makanan, merupakan bagian dari etika religius dalam hubungannya antara manusia dan Tuhan. Karena tujuan dari pendidikan adalah untuk meningkatkan ketaqwaan dan keimanan kepada Tuhan yang Maha Kuasa, maka nilai dan norma serta etika religius secara otomatis melingkupi proses tersebut. Hal ini dengan sendirinya berarti meliputi semua pelaku pendidikan yaitu pendidik serta peserta didik, yang mengalami peningkatan secara keseluruhan. Sebagai konsekuensinya, peserta didik juga mengalami peningkatan baik pengetahuan maupun rasa religiusitasnya. ${ }^{71}$

Dengan memiliki integritas religius, maka seseorang entah bereligi atau orang yang tidak religius bukan satu yang terpisah

\footnotetext{
${ }^{70}$ Bernadib (2002), hlm. 18.

${ }^{71}$ Ibid., hlm. 26.
} 
dari kepribadiannya, melainkan turut menentukan sikap orang itu dalam semua bidang kehidupannya, jadi tidak hanya dalam kegiatan khas saja. Integritas religius menuntut kerendahan hati yang memberikan kebebasan pada orang lain, tidak mau memakai kekuasaan untuk memajukan keyakinan religiusnya. Tuntutan itu berasal dari integritas dan kejujuran religius, karena religiusitas hanyalah benar apabila mengakui kemahadaulatan Allah dan pengakuan itu hanya nyata apabila dibuktikan dalam sikap hormat terhadap cara bagaimana Yang Maha Kuasa berkenan menyentuh dan bergaul dengan hati segenap orang dan alam semesta. Integritas religius menuntut hormat yang sebesar-besarnya terhadap kebebasan Allah dan kebebasan beragama sesama. ${ }^{72}$

Terdapat hubungan yang erat sekali antara integritas religius dan integritas intelektual dan moral. Secara moral, integritas religius hanya utuh apabila disertai kerendahan hati dalam hal agama, disertai hormat terhadap segenap manusia dalam keyakinan dan sikap hidup yang diyakininya. Integritas religius tidak mencemarkan kemurnian agama.

Pada setiap agama dapat dibedakan ajaran dogma dan ajaran moral. Ajaran dogma membahas iman kepercayaan tentang hakkat Tuhan, hubungan Tuhan dengan dunia, kedudukan para nabi agama bersangkutan dan sebagainya. Ajaran moral atau etika menjelaskan apa yang harus dilakukan dan apa yang tidak boleh dilakukan. Ajaran moral membeberkan nilai dan norma etis yang dijunjung tinggi dalam suatu agama. Jika membandingkan ajaran dogma dengan ajaran moral yang terdapat dalam agama-agama yang berbeda, ternyata sulit menghindari kesimpulan bahwa terutama ajaran dogmalah yang memisahkan umat beragama yang

Suseno, Franz Magniz, Berfilsafat dari Konteks (Jakarta: Gramedia, 1992), hlm. 154. 


\section{Refleksi Teoretis Etika Religius Syaikh Yusuf}

kadang-kadang berbeda. Berbagai agama mempunyai ajaranajaran dogma yang kadang berbeda. Misalnya ada agama yang bersifat politeistik. Agama lain memiliki pandangan monoteistik. Di antara agama-agama yang berpandangan monoteistik pun ditemukan banyak perbedaan pendapat. ${ }^{73}$

Berkaitan dengan etika religius atau pengejawantahan ajaranajaran etika agama dalam tingkah laku sehari-hari, perlu dicamkan bahwa etika religius bersumber dari iman yang tentunya dapat dipertanggungjawabkan secara teologis dan filosofis. Oleh karena itu, etika religius dapat dipertanggungjawabkan secara teologis dan filosofis. Secara teologis, iman dapat dipertanggungjawabkan apabila dapat menunjukkan bahwa apa yang diimani serta kehidupan yang dijalani berdasarkan iman itu, adalah sesuai dengan sumber iman itu. Jadi teologi berdasarkan wahyu agama yang bersangkutan. Wahyu itulah sumber kebenaran. Setiap agama mempunyai wahyu atau dasarnya sendiri, sehingga setiap agama mempunyai teologinya sendiri. Pertanggungjawaban iman secara teologis terjadi dalam rangka refleksi dan diskursus iman di dalam umat beragama yang bersangkutan. Orang luar tidak dapat masuk karena tidak mengakui atau terikat dengan wahyu agama itu sebagai sumber kebenaran. ${ }^{74}$

Pertanggungjawaban filosofis iman adalah berbeda. Di situ, yang ingin ditunjukkan adalah rasionalitas iman yang dilakukan dengan memakai nalar. Nalar dapat memeriksa suatu keyakinan atau ajaran agama dari beberapa sudut, misalnya dari sudut konsistensi logis, apakah ada pertentangan di antara ajaran-ajaran agama. Dari sudut pengetahuan tentang dunia dan masyarakat, misalnya apakah ajaran tentang penciptaan dunia dapat diper-

\footnotetext{
${ }^{73}$ Bertens, K., Etika (Jakarta: PT. Gramedia Pustaka Utama, 2002), hlm. 159.

${ }^{74}$ Suseno, Franz Magniz, Menalar Tuhan (Yogyakarta: Kanisius, 2006), hlm. 21 22.
} 
tanggungjawabkan dari sudut pengetahuan ilmu-ilmu tentang alam raya, perkembangan hayat di bumi dan lain lain. Juga dari sudut pengalaman batin. Filsafat Ketuhanan sebagai filsafat tidak mendasarkan diri pada ajaran atau wahyu agama tertentu, tetapi bertanya, apa yang secara nalar dapat dikatakan tentang iman. ${ }^{75}$

Filsafat tentu saja tidak membicarakan seluruh iman kepercayaan suatu agama, melainkan hanya intinya. Keyakinan iman bahwa Allah itu ada dengan segala kualifikasinya.

Berdasarkan paparan-paparan di atas, dapat diketahui beberapa pandangan dan perdebatan tentang filsafat etika dalam kaitannya dengan kehidupan manusia. Bila diperhatikan, hampir kebanyakan filsafat etika lebih menekankan pentingnya hubungan dan masa depan masyarakat dalam kaitannya dengan hubungannya satu sama lain. Hal ini misalnya dapat diamati ketika persoalan kebenaran dan tanggung jawab moral setiap individu terkait dengan tanggung jawab dan keberadaannnya di dunia ini dengan kehidupan orang lain. Filsafat etika agama tidak mendapat analisisanalisis yang cukup tajam.

Sebagaimana disinggung dalam bab-bab terdahulu bahwa Syaikh Yusuf merupakan seorang sufi dan ahli hukum Islam. Dengan demikian perlu kiranya mengetahui hakikat sejarah tasawuf dan sekelumit pandangan ulama sufi tentang etika kepada pencipta atau etika religius. Periode sufisme awal bisa dikatakan bermula pada masa Nabi Saw. dan berlanjut sampai paro pertama abad IX, ketika terjemahan buku-buku Yunani, Persia, dan India mulai tersedia di kalangan kaum muslim. Al-Qusyairi mencatat tentang hal ini, yaitu: Ibrahim bin Adham, Dawud al-Thay, Ma'ruf alKarkhi, Abu Said Hasan al-Basri, serta Abu al-Abbas al-Sabti, putra khalifah Harun al-Rasyid, yang mengorbankan dunianya demi

75 Ibid., hlm. 22. 


\section{Refleksi Teoretis Etika Religius Syaikh Yusuf}

sebuah kehidupan yang penuh dengan ketaaatan, kesalehan, dan penyepian diri. ${ }^{76}$

Kaum sufi pada periode pertama ini mungkin lebih tepat disebut para pertapa asketis ketimbang para sufi, karena tidak membedakan antara syari'at dan tarekat, dan mengikuti segala ketaatan beragama pada sisi luarannya, mendasarkan pengetahuan agamanya semata-mata pada al-Qur;an dan tradisi serta tidak menambahkannya dengan pengalaman sendiri. Dalam kenyataannya, kaum sufi ini tampak tidak memiliki pengalaman tersebut, tidak memiliki doktrin-doktrin sufisme dan sistem sendiri, tetapi sepenuhnya menerima keimanan muslim sebagaimana dikenal khalayak dan meyakininya. Kaum sufi ini tidak mengetahui doktrin panteisme. ${ }^{77}$

Kaum sufi pada periode ini menjalani hidup yang penuh dengan pantangan, bukan karena ingin menjauhkan diri dari hasrat dan nafsu tetapi karena ingin mengikuti cara hidup sang rasul dengan caranya sendiri. Puritanisme awal yang disalahpahami masa berikutnya, memberikan kontribusi terhadap masa berikutnya berupa kebangkitan asketisisme, dan berkonsentrasi pada ide tentang hari pembalasan dan tentang kerugian para pendosa, sehingga akibatnya begitu kental dalam beragama. Sufi Abu Hasyim sangat terkesan oleh ajaran al-Qur'an tentang dosa, hari pembalasan dan sebuah bagian singkat tentang kehidupan duniawi. Di luar materi itu ia mengembangkan definisi sufisme yang dikemukakan oleh Ma'ruf al-Karkhi sebagai pemahaman atas realitas Ketuhanan. ${ }^{78}$

Bentuk awal sufisme karenanya memperlihatkan karakter kedamaian yang saleh. Ia pantang terhadap pamer kekayaan dan

\footnotetext{
${ }^{76}$ Khan, Ali Mahdi, The Elements of Islamic Philosophy (terj.) (Bandung: 1999), hlm. 115.

77 Ibid., hlm. 116.

78 Ibid.
} 
pantang mengikuti hawa nafsu, juga menganjurkan kesederhanaan hidup, bukannya kemiskinan sukarela dan aib. Para sufi meninggalkan kehidupan duniawi kadang-kadang saja, tetapi satu atau dua orang darinya juga mengadopsi gaya hidup pertapa.

Sufisme lanjutan atau sufisme doktriner terjadi pada masa penyebaran pengetahuan Yunani, Mesir, Persia, dan India, yang terjadi pada abad IX M, memang mempengaruhi sufisme, seperti halnya filsafat muslim yang terpengaruh oleh pengetahuan asing. Doktrin-doktrin filsafat dan teori-teori metafisika diperkenalkan kepada sufisme. Sufisme paling awal, yang hanya merupakan sebuah jalan hidup yang saleh dan meditasi yang tekun, diikuti dan dipraktikkan hanya oleh yang cukup terpelajar untuk bisa mulai memasuki misterinya. Orang pertama yang menganjurkan diperkenalkannya dokrin filsafat ke dalam sufisme adalah Dzun nun al-Misri, yang wafat tahun 859 M. Perkembangan sufisme doktriner dikatakan bermula dan diakhiri oleh Jalaluddin Rumi, seorang Persia. Rumi lahir pada tahun 1207 se-zaman dengan Ibnu Arabi, namun Rumi lebih muda.79

Perkembangan sufisme doktriner selanjutnya bisa dibagi ke dalam dua periode berbeda, dan tahun wafatnya al-Ghazali (1111 M) disebut-sebut sebagai titik pembatas antara kedua periode itu. Sebelum masa al-Ghazali, kaum sufi dianggap bidah karena berinovasi dan karena perpaduan antara doktrin-doktrinnya dengan pandangan-pandangan kaum Syiah ekstrem. Al-Ghazali, di satu sisi mempengaruhi dogma-dogma agama melalui sufisme dan di sisi lain memodifikasi sufisme agar cocok dengan dogmadogma tersebut, sehingga bisa menghasilkan rekonsiliasi di antara keduanya. Kebesarannya sebagai seorang teolog dan keberaniannya menegakkan sufisme, menyebabkan sufisme menerima pengakuan resmi dan diperkenalkan dalam teologi ortodoks. Sejak

${ }^{79}$ Ibid., hlm. 117. 


\section{Refleksi Teoretis Etika Religius Syaikh Yusuf}

itu sufisme menguat. Para sufi yang muncul setelah al-Ghazali dianggap sebagai orang-orang yang suci religius oleh kalangan muslim ortodoks dan sungguh tidak terkait dengan gerakan Islam di Persia dan tidak selalu setia kepada prinsip-prinsip yang diletakkan al-Ghazali serta tidak jarang melampaui batas pendirian standar agama ortodoks. Tetapi penghormatan yang didapatkan dari khalayak muslim yang pernah ditegakkan oleh al-Ghazali tidak pernah hilang. Wakil-wakil utamanya pada periode sebelum alGhazali ketika sufisme akrab dengan kaum Syiah dan orang-orang Persia adalah: Dzunnun al-Misri, Junaid al-Baghdadi, Mansur alHallaj, Syibli dari Khurasan, Abu Utsman dari Nisyapur, Abu Said bin Abu al-Khair, Abu Nasr al-Sarraj al-Thusi, Abu al-Qasim alQusyairi, al-Hujwiri, Abdul Qadir Jailani, dan Abu Yazid al-Bistami. Pada periode kedua setelah al-Ghazali, wakil-wakil utamanya adalah Taj al-Din bin Atha Allah dari Alexandria, Jamal al-Din Abdul al-Razzaq, Abdul Karim al-Jilli, Muhy al-Din Ibnu Arabi, Syahab al-Din Suhrawardi dari Baghdad, Khawaja Nizam al-din Auliya dari India, Fariduddin Attar dari Nisyapur, Abdurrahman Jami, dan Jalaluddin Din Rumi, penulis Masnawi yang terkenal. ${ }^{80}$

Cita-cita sufisme adalah pengetahuan akan realitas akhir yakni Tuhan. Pengetahuan ini diperoleh bukan melalui pemikiran spekulatif, melainkan melalui gnosis atau makrifat. Gnosis (makrifat) hanya mungkin bagi manusia yang telah menyempurnakan intelektual dan diri moralnya, juga mencurahkan diri secara khusus pada meditasi, cinta, kesalehan dan kesucian. Pengetahuan (dengan dimensi etika), menurut kaum sufi ada tiga jenis:

1) Pengetahuan dari Tuhan

2) Pengetahuan bersama Tuhan

3) Pengetahuan tentang Tuhan

${ }^{80}$ Ibid., hlm. 118. 
Pengetahuan tentang Tuhan adalah gnosis. Pengetahuan dari Tuhan adalah pengetahuan tentang agama dan teologi yang merupakan hukum Tuhan dan tanggung jawab manusia. Pengetahuan bersama Tuhan adalah pengetahuan tentang tahapantahapan, jalan kebenaran dan deskripsi tentang tingkatan orang suci. Barangsiapa yang tidak memiliki gnosis, maka dia telah mematikan hatinya dengan kebodohan, dan hati manusia yang tidak mempelajari agama adalah hati yang sakit karena kebodohan. Karenanya kaum sufi menjadikan pengetahuan agama dan teologi termasuk filsafat sebagai sebuah prasyarat wajib dalam memulai sufisme, sehingga hanya para intelektual terbaiklah yang bisa menjadi sufi.

Oleh karena itu, ditemukan banyak filsafat dalam sufisme. Setelah menyelesaikan karier akademis dan menjadi seorang ilmuwan sains spekulatif, orang yang sedang belajar menjadi sufi harus mempersiapkan diri untuk mengikuti jalan mistik dalam memperoleh pengetahuan tertinggi dengan menjalani hidup penyucian. Ini dirancang untuk menyucikan jiwa dari hasrat ilmiah dan keinginan jahat serta membebaskan jiwa dari kecenderungan dosa. Idenya adalah bahwa pemikiran praktis melengkapi dan memperkuat pemikiran spekulatif dan penglihatan terhadap realitas yang lebih tinggi hanya mungkin bagi yang memadukan akan dengan nilai moral atau etika keagamaan yang sejati. Kebaikan dan pengetahuan berjalan bersama dan berhubungan baik, sehingga seseorang yang jahat tidak bisa menjadi seorang ilmuwan yang baik. Jiwa yang bermoral mulia, yang memiliki etika religius yang tinggilah yang diperlukan untuk menerima bentuk kebenaran. ${ }^{81}$

Berdasarkan penjelasan-penjelasan di atas, maka moral yang mulia atau moralitas religius dalam ajaran Syaikh Yusuf dapat diungkapkan sebagai berikut:

${ }^{81}$ Khan (1999), hlm. 119-120. 


\section{Refleksi Teoretis Etika Religius Syaikh Yusuf}

1) Sebagai etika yang tinggi dan menjadi kata kunci dalam pelaksanaan kewajiban dan tugas dalam kehidupan sehari-hari, baik dalam hubungan antarmanusia maupun antara manusia, alam, dan Tuhan.

2) Moralitas religius adalah kualitas dalam perbuatan manusia yang menunjukkan bahwa perbuatan itu benar atau salah, baik atau buruk. Moralitas mencakup pengertian tentang estetisnya perbuatan manusia.

Berkaitan dengan inilah maka ajaran agama yang menekankan tentang etika menjadi pembahasan yang berkaitan erat, dan Tuhan adalah sumber dan norma dari segala sesuatu yang ada. Selain itu, Tuhan juga merupakan sumber dan norma segala kebaikan. Sebab terakhir mengapa suatu perbuatan manusia itu baik adalah karena mengambil bagian dalam kebaikan Tuhan. Sebab terakhir mengapa suatu perbuatan manusiawi itu buruk ialah karena berlawanan dengan aktivitas dan hakikat Tuhan, sebagai mata air sumber segala kebaikan. Ringkasnya, norma terakhir moralitas harus menjadi patokan terakhir dan mutlak, yang merupakan titik acuan dalam memutuskan kebaikan perbuatanperbuatan manusiawi. Patokan terakhir semua kebaikan, baik kebaikan perbuatan manusiawi atau sesuatu yang lain adalah hakikat Ilahi. Maka norma terakhir adalah etika religius. ${ }^{82}$

Oleh karena itu, ajaran-ajaran agama seringkali juga dipahami sebagai bagian dari ideologi seseorang yang menggerakkan setiap perbuatan. Ideologi agama, sebagaimana ideologi-ideologi dan ajaran-ajaran filsafat yang lain, memanggil subjek atau individuindividu yang terkait untuk melaksanakan ide-ide yang tergambar dalam pikirannya dengan memperhatikan kondisi riil dalam masyarakat. Dalam hal inilah ideologi agama sebagaimana ideologi

${ }^{82}$ Poespoprodjo, W., Filsafat Moral, Kesusilaan dalam Teori dan Praktek (Bandung: Pustaka Grafika, 1998), hlm. 151. 
lain yang telah disebutkan memiliki etika-etikanya tersendiri, menggerakkan masyarakat dalam perubahan sosial. Sebagaimana dalam kasus revolusi Bolsyevik di Rusia yang dipimpin Lenin, digerakkan oleh ideologi Marxis untuk mencapai keadilan masyarakat tanpa kelas menurut versinya. ${ }^{83}$

Di sinilah arti penting etika religius dalam konteks ideologi yang menggerakkan individu untuk mengubah suatu tatanan masyarakat agar lebih baik lagi. Dalam sejarah Islam awal, konsep ideologi Islam yang menggerakkan tergambar dalam bingkai etika religius tauhid yang menekankan pentingnya etika hubungan antara manusia dan Tuhan serta manusia dan manusia. Dalam sejarah nabi, sebagaimana telah diuraikan dalam bab terdahulu, bahwa munculnya Islam sebagai agama baru di Arabia pada saat itu berawal dari kerusakan etika dalam masyarakat Arab. Islam sebagai ideologi yang mengusung ajaran etika tauhid dan kemanusiaan menyatakan dengan tegas dalam perkataan nabi bahwa nabi diutus untuk menyempurnakan akhlak atau etika yang mulia demi tegaknya masyarakat yang baik dan teratur. Dari sini dapat dilihat, bahwa ideologi agama yang didasarkan etika religius yang tinggi dapat menjadi pendorong gerakan perubahan sosial masyarakat dengan tetap mengacu pada kebaikan dan kemaslahatan bagi seluruh umat. Dalam kaitan ini, dakwah Islam merupakan suatu medium untuk mewujudkan prinsip-prinsip dan ajaran etika religius.

Berkaitan dengan pandangan etika religius Syaikh Yusuf, yang menekankan pentingnya etika individu dalam kaitannya dengan kehidupan bermasyarakat dan sosial serta tanggung jawab setelah kehidupan ini, yaitu kehidupan masa depan di alam yang berbeda yaitu alam akhirat, maka tanggung jawab, bagi etika religius Syaikh

${ }^{83}$ Althuser, Louis., Lenin and Philosophy, and Other Essays (terj.), (Yogyakarta: Indonesia oleh Team Resist Book, 2007), hlm. 185-221. 


\section{Refleksi Teoretis Etika Religius Syaikh Yusuf}

Yusuf yang berdasarkan keislaman kepada Tuhan sang pencipta, memiliki dimensi universal kemanusiaan sekaligus dimensi primordial antara manusia dan Tuhan. Dimensi universal tentu saja amat penting dalam kehidupan sekarang. Namun berbeda dengan kebanyakan pandangan filosof Barat yang seringkali mengabaikan agama, karena kekecewaan terhadap agama Kristen, dalam hal ini pemikir Islam melihat lebih jauh pada filsafat agama tentang tanggung jawab manusia sebagai makhluk yang diciptakan oleh Tuhan sebagai wakil Tuhan untuk memakmurkan bumi. Oleh karena itu, nilai-nilai universal etika religius dalam Islam tidak hanya berkenaan dengan hubungan masyarakat di dunia ini tetapi juga berhubungan dengan etika pada sang pencipta. Dua hal yang dalam Islam disebut hablum minallah dan hablum minannas atau hubungan dengan Tuhan dan manusia inilah yang menjadi landasan etika religius yang dikembangkan oleh Syaikh Yusuf.

Menurut pandangan Syaikh Yusuf, yang tentu saja bersumber dari Islam, kedua hal tersebut harus seimbang. Apabila salah satu ditinggalkan, maka tidaklah sempurna. Secara etika kemanusiaan, manusia memang cukup untuk berbuat baik kepada sesamanya tanpa harus memperhatikan dan melaksanakan ajaran-ajaran seremonial agama. Artinya manusia dapat menjadi manusia yang baik hanya dengan melaksanakan ajaran-ajaran universal agama.

Namun, ajaran etika religius dalam pandangan Syaikh Yusuf adalah manusia harus mengingat asal muasal keberadaan dirinya. Hal ini merupakan hal yang sangat primordial, dalam pengertian bahwa tanggung jawab pribadi kepada sang pencipta harus diwujudkan dalam sikap etika yang primordial antara dirinya dan penciptanya. Tanggung jawab etika primordial ini berkenaan dengan keyakinan keagamaan yang dianut seseorang, dan tentu saja tanggung jawab hal ini tidak dapat secara universal ditanggung bersama-sama. 
Inilah hal terpenting yang menjadi inti pandangan etika Syaikh Yusuf. Hal tersebut juga sesuai dengan pandangan filosof Jerman, Sooren Kierkegaard. Pisau analisis dalam kajian ini adalah bahwa manusia tetap dapat menjadi saleh dan baik dalam menjaga etika primordial antara dirinya dengan Tuhan sekaligus juga menjadi manusia yang secara sosial baik kepada sesamanya. Ringkasnya, saleh secara sosial dan saleh secara individual.

Beberapa pokok pikiran yang perlu mendapat perhatian dalam rangka merekonstruksikan kembali konsep-konsep etika religius untuk kehidupan masa kini dan masa depan adalah dengan memperhatikan kebutuhan masyarakat yang secara umum dapat dibagi menjadi kebutuhan materi dan spiritual.

Pertama, kebutuhan materi. Kebutuhan materi berkenaan dengan etos kerja yang menghasilkan produksi materi demi kebutuhan hidup sehari-hari. Berdasarkan perdebatan kaum filosof etika seperti diterangkan di atas, bahwa etos kerja dan hasil produksi yang bermanfaat berhubungan dengan pandangan filosofis manusia yang bekerja dan memiliki etika atau moral yang baik. Etika atau moral yang baik berhubungan dengan rasa tanggung jawab terhadap masyarakat. Dalam hal ini, bila etika religius menjadi landasan dalam setiap perbuatan, baik kerja maupun dakwah, maka kesadaran bahwa tanggung jawab setiap perbuatan tidak hanya kepada manusia, tetapi juga kepada Tuhan yang akan meminta pertanggung jawaban di akhirat. Dengan demikian, dalam melakukan kerja untuk kebutuhan hidupnya, seseorang akan memperhatikan etika sosial sebagai tanggung jawab kepada manusia lain selain kesadaran akan tanggung jawab kepada Tuhan.

Kedua, berkaitan dengan kebutuhan spiritual. Kebutuhan spiritual dalam kaitannya dengan etika religius adalah bahwa setiap pekerjaan dan tindakan yang dilakukan selalu didasarkan 


\section{Refleksi Teoretis Etika Religius Syaikh Yusuf}

pada etika atau moral yang mengacu pada ajaran-ajaran luhur keagamaan. Dengan mengacu pada ajaran-ajaran luhur keagamaan, maka kebutuhan spiritual juga termanifestasi dalam kerja-kerja nyata. Dalam kaitannya dengan dakwah yang dibutuhkan oleh masyarakat modern, kedua aspek ini menjadi sangat penting. ${ }^{84}$

Menurut Syaikh Yusuf, segala sesuatu yang dilakukan dan berkenaan dengan pelaksanaan ajaran Islam, haruslah memiliki dua aspek yaitu aspek lahir dan batin. Apabila tidak ada aspek lahir dan batin, maka suatu tindakan merupakan tindakan yang tidak bermakna. Oleh karena itu, tindakan etis termasuk dakwah yang etis adalah tindakan dan dakwah yang etis-sufistik, yaitu untuk mengubah hidup tanpa makna atau nonsense menjadi dunia hidup yang penuh makna atau sense. Shalat misalnya haruslah memiliki aspek lahir dan batin, tidak hanya secara lahiriah saja. Aspek lahir batin ini mempertautkan antara rukun-rukun atau ritualnya dengan arti serta efek ungkapan pernyataan dalam shalat itu. Misalnya, memahami "mengapa orang yang shalat memproklamasikan Allahu Akbar? Meletakkan kepalanya yang dijaga, dihormati di atas lantai, sejajar dengan tanah, dan seterusnya. Inilah bagian dari etika religius dalam kaitannya dengan hubungan manusia dan Tuhan. Aspek lahir dan batin, tidak hanya secara lahiriah. Hal ini merupakan implementasi dari pelaksanaan etika dalam kaitannya dengan hubungan manusia dan Tuhan dalam kehidupan sehari-hari.

Perlu disadari bahwa masyarakat global modern saat ini terdiri atas masyarakat dari berbagai bangsa dan negara di dunia yang berhubungan satu sama lain untuk berbagai kepentingan, seperti ekonomi, sosial budaya, politik dan pendidikan serta lain sebagainya. Hubungan ini diwarnai dengan sikap saling ketergantungan. Oleh karena itu, hubungan antarbangsa ini dapat

${ }^{84}$ Darusman (2008), hlm. 287. 
menumbuhkan homogenitas pada lingkungan yang heterogen. Dikatakan homogenitas karena nilai-nilai dan norma-norma tertentu ada kalanya sangat berpengaruh sehingga sifat, corak berpikir atau perbuatan tertentu mempunyai kesamaan di antara bangsa-bangsa tertentu. Salah satunya adalah kemodernan. Kemodernan menuntut adanya kemampuan berpikir dan berbuat. Hal ini telah terjadi dimana-mana dan menjadi ciri utama pada bangsa-bangsa yang berjuang mencapai kemodernan tersebut. Akibatnya, bangsa-bangsa mudah berkomunikasi karena homogenitas tersebut. Hal yang tidak dapat dilepaskan dari kenyataan adalah adanya sifat-sifat yang berlandaskan heterogenitas. Tiap bangsa mempunyai adat istiadat dan kebudayaan yang merupakan ciri khas dari bangsa yang bersangkutan. Namun, meski dengan perbedaan-perbedaan yang ada, tetap mencari hubungan satu sama lain. ${ }^{85}$

Oleh sebab itu, etika religius memainkan peranan yang penting. Dalam hal ini patut dicamkan bahwa sufisme bukanlah suatu ajaran yang mengajarkan fatalisme. Konsep-konsep dalam sufisme yang berdasarkan ajaran Islam bahkan mengajarkan untuk bersikap dinamis dalam hidup dengan tetap memperhatikan tujuan akhir, yaitu mencapai keridaan Tuhan, karena Tuhan memberikan pilihan kepada manusia untuk memilih yang terbaik. ${ }^{86} \mathrm{Hal}$ ini merupakan suatu bentuk etika religius yang diajarkan oleh Syaikh Yusuf.

Etika religius Syaikh Yusuf dalam dakwah Islam dilihat dalam konstruksi filsafat, dan disebut sebagai etika dakwah yang kosmosentris dan teosentris. Kosmosentris adalah bahwa etika religius tersebut dalam kaitannya dengan dakwah Islam, meletakkan alam dan manusia sebagai objek dan wacana filsafat sufismenya.

\footnotetext{
${ }^{85}$ Bernadib (2002), hlm. 71.

${ }^{86}$ Darusman (2008), hlm. 295.
} 


\section{Refleksi Teoretis Etika Religius Syaikh Yusuf}

Sedangkan teosentris adalah bahwa Tuhan dalam etika religius Syaikh Yusuf dan dakwah Islam, diletakkan sebagai pusat pembahasan filsafat. ${ }^{87}$ Artinya, seluruh interpretasi ajaran etika Islam yang dikembangkan dalam dakwahnya dimaksudkan oleh Syaikh Yusuf sebagai pengabdian kepada Tuhan. Oleh karena itu, pola dakwah yang dikembangkan oleh Syaikh Yusuf, yang berlandaskan ajaran cinta kasih dan kedamaian Islam, telah sesuai dengan misi Islam yaitu rahmatan lil alamin (rahmat bagi semesta). Bila seseorang telah dapat melaksanakan syari'at Islam secara lahir dan batin, maka ia akan dapat mencapai derajat al-Insan al-Kamil (manusia sempurna, yang dalam filsafat Nietzsche disebut Übermensch, manusia sempurna, manusia masa depan yang mendekati karakter Ketuhanan). ${ }^{88}$

Setidaknya, secara keseluruhan ada lima kunci dari karyakarya Syaikh Yusuf yang sangat penting untuk dicermati, yaitu pentingnya tauhid, syari'at Islam, tarekat, makrifat, atau filsafat tentang Ketuhanan dan hakikat atau wahdat al-wujud atau filsafat tentang kesatuan eksistensi. Artinya alam ini adalah cerminan dari eksistensi Tuhan. ${ }^{89}$ Oleh karena itu, berkaitan dengan pola keberagamaan saat ini dan pola-pola dakwah yang dikembangkan oleh sebagian umat Islam yang bercorak radikal, pada hakikatnya tidak sesuai dengan filsafat dakwah Islam bahkan bertentangan dengan misi suci kenabian dalam Islam.

Dengan membaca karya Syaikh Yusuf, muncul koreksi terhadap pandangan hidup yang hanya tersusun di atas kedangkalan dimensi esoteris dalam kehidupan dunia. Syari'at tanpa tarekat, makrifat, dan hakikat, dan demikian sebaliknya bagaikan hidup tanpa tuntunan yang kuat. Kekuatan dan kemauan

\footnotetext{
${ }^{87}$ Kaelan, M.S., Etika Lingkungan (Yogyakarta: Paradigma, 1999), hlm. 7.

${ }^{88}$ Darusman (2008), hlm. 302-207.

${ }^{89}$ Ibid., hlm. 340-341.
} 
sebagaimana Ibnu Arabi, dari syari'at sampai hakikat di dalam ajaran Syaikh Yusuf, merupakan pokok keberhasilan mengatasi problematika kehidupan. Manusia menjadi sadar bahwa kekuatan dan kemauan untuk mengamalkan agama termasuk untuk mengembangkan dakwah agama, harus dibarengi dengan "bayangbayang" kehadiran Sang Penentu dan Penilai benar dan salahnya, atau baik dan buruknya cara beragama. Mengakui adanya Dia, berarti semua yang dimiliki relatif dan bukan standar utama atas kebenaran maupun kebaikan. Kebenaran dan kebaikan mutlak serta pengklaimannya hanya milik Dia, hanya Dialah yang bisa sombong, angkuh, arogan, berkuasa, dan menguasai. Walaupun sifat-sifat itu amat mungkin Dia tunjukkan, tetapi kenyataannya, jarang dilakukanNya, mengapa sebagian atau mungkin seluruh manusia merasa bisa benar dan baik segala-galanya? Seorang ulama yang sudah lama meninggalkan dunia dan memberikan konsep sebagai koreksi atas kekeliruan dalam beragama, bisa jadi tidak tenang bahkan marah di alam sana, melihat tingkah manusia yang berani menduduki kursi-kursi kekuasaan yang tidak pernah sedikitpun ditinggalkan oleh Yang Maha Kuasa. Humanisme Islam adalah kemanusiaan yang bermoral, beretika, dan etika humanisme, ${ }^{90}$ sebagaimana yang diajarkan oleh Syaikh Yusuf ditampilkannya dalam tiga wilayah sekaligus, yakni ulama, birokrat, dan sufi.

90 Soejadi, Mensyukuri Karunia Allah (Jakarta: Pustaka Pergaulan, 2008), hlm. 125. 


\section{Bab VI \\ PENUTUP}

Syaikh Yusuf dikenal sebagai figur dai, ahli tarekat, sekaligus ulama syari'at yang andal. Sebagai sufi besar, ia menguasai dan mengamalkan ajaran Islam secara menyeluruh dan telah mencapai puncak pendakian spiritual tertinggi dalam suluknya, sehingga menjadi wali yang suci dan karomah, bahkan ia berperan juga dalam persoalan sosial dan politik. Ia menjadi tokoh ulama di Kerajaan Islam Makassar, mufti di Kerajaan Islam Banten, juga pejuang yang memiliki patriotisme besar melawan kedzaliman penjajah di Nusantara, bahkan menjadi tokoh yang berpengaruh di berbagai negara. Syaikh Yusuf adalah salah satu mujadid terpenting dalam sejarah Islam di Indonesia. Jejaknya meliputi wilayah yang sangat luas, dari Sulawesi Selatan dan Jawa Barat, sampai ke Arabia, Sri Lanka, dan Afrika Selatan.

Dimensi sufistik ajaran-ajaran Syaikh Yusuf sangat dominan. Keterlibatan Syaikh Yusuf dalam dakwah dan tarekat sangat ekstensif. Hal ini terlihat pada pengembaraan pengetahuan dan spiritualnya ke berbagai daerah sejak di Makassar hingga ke beberapa negara.

Pandangan filsafat Syaikh Yusuf merupakan paduan dari dari para filosof Yunani kuno yang diinterpretasi oleh tokoh-tokoh pemikir Islam sebelum Syaikh Yusuf, yang kemudian mengalami perbedaan corak. Pemikiran Syaikh Yusuf dipengaruhi oleh tokoh- 
tokoh berpengaruh seperti Ibrahim bin Adham, Imam al-Ghazali, Ibnu 'Ataillah al-Iskandari, Abdul Qadir Jailani, Abdul Karim alJilli, dan Rabiah al-Adawiyah serta dua tokoh lain yang jarang disebut dalam karya-karyanya, yaitu Ibn Arabi dan Ibn Miskawih.

Teori-teori etika religius yang dikembangkan Syaikh Yusuf bersumber dari Al-Qur'an, tentang manusia dan kedudukannya di alam semesta. Etikanya didasari pada pandangan dunia Al-Qur'an, sunnah, konsep-konsep teologi, kategori-kategori filsafat, dan sufisme. Unsur utama pemikiran etika ini berpusat pada dunia dan manusia. Sistem etika ini muncul dalam bentuk yang kompleks, yaitu teosentris, antroposentris, dan kosmosentris. Bangunan konsep Syaikh Yusuf merupakan perpaduan antara unsur akal (rasio), rasa (estetis), dan kehendak (etika yang berbasis ilahiah).

Konsepsi Syaikh Yusuf tentang Tuhan (teologi) bercorak sintesis antara paham ta'thil (pengosongan Tuhan dari sifat-sifat) dan paham tasybih. Mengenai alam semesta (kosmologi), tampaknya Syaikh Yusuf terpengaruh oleh para pemikir sebelumnya. Hakikat alam adalah tidak ada. Yang ada hanya Tuhan yang menciptakan. Karena itu, semua yang diciptakan oleh Yang Ada hanya penampakan lahir (tajali) dari Tuhan. Sementara tentang manusia (antropologi), Syaikh Yusuf mengatakan bahwa hakikat manusia adalah bayangan Tuhan di muka bumi. Namun demikian, antara Tuhan dan hamba harus tetap ada perbedaan. Hamba tetap hamba betapa pun ia telah sampai ke puncak kesatuan dengan Tuhan, dan Tuhan tetap Tuhan meskipun Dia turun kepada hambaNya. Manusia yang seperti ini disebut sebagai insan kamil.

Konsep etika Syaikh Yusuf pada hakikatnya berdasarkan prinsip al-takhalluq bi akhlaq Allah (berakhlak dengan akhlak Allah). Moralitas hidup harus seiring dengan sikap dan perilaku yang beradab. Keberadaban ini tidak hanya sekadar rasa solidaritas 


\section{Penutup}

sosial, tetapi juga merupakan solidaritas yang didasarkan pada unsur-unsur primordial. Relasi etika Syaikh Yusuf dan dakwah Islam berhubungan dengan tiga hal, yaitu: manusia, pribadi, dan makhluk Tuhan. Etika religius Syaikh Yusuf merupakan pandangan moralitas religius yang universal, mencakup kebutuhan materiil dan spirituil. Secara materiil, ia menjadi landasan etos kerja dan aktivitas serta menjadi pendorong berkarya sebagai bentuk tanggung jawab sosial kepada sesama manusia. Secara spirituil, ia melandasi segala aktivitas kehidupannya dalam bingkai etika religius dan menyadari bahwa tanggung jawabnya tidak hanya kepada manusia dan berhenti di dunia saja, namun juga kepada penciptanya.

Berbeda dengan tawaran-tawaran konsep etika sekuler, etika religius Syaikh Yusuf sebagaimana pandangan Sooren Kierkegaard dan Toshishiko Isutzu, dilandasi oleh ajaran-ajaran moral agama yang memiliki tujuan ganda, yaitu tujuan untuk kehidupan riil saat ini dan kehidupan yang dijanjikan Tuhan di masa mendatang. Untuk menjadi hamba Tuhan yang saleh, manusia perlu menjadi saleh secara sosial, sehingga kesalehannya dapat memberikan hasil kepada masyarakat dalam kehidupan sehari-hari.

Konsep insan kamil Syaikh Yusuf terfokus pada esensi kesucian, yakni spiritual manusia yang akan mengantarkan manusia ke alam ilahiah (alam ketuhanan), melalui potensi batin yang dimilikinya sebagai indikasi kesempurnaan spritualnya. Konsep-konsep seperti ini adalah sesuatu yang batin (dalam), bahwa perkembangan dimensi batin manusia harus diupayakan melalui perjalanan rohani yang sangat berat (mujahadat) dan latihan spiritual yang terus-menerus (riyadah), karena dimensi batin manusia merupakan hakikat dirinya. Idealisasi kesempurnaan manusia merujuk pada diri Nabi Muhammad Saw. dari sisi kesempurnaan jiwanya dalam merefleksikan sifat-sifat ketuhanan. Dengan mencontoh perilaku Nabi, manusia dimungkinkan dapat 
memanifestasikan pola relasinya dengan Tuhan dan dengan etika kebudayaan yang sempurna. Dalam rangka pendakian menuju ke maqam insan kamil, manusia harus merujuk pada syari'at, tarekat, hakikat, dan makrifat. Tingkatan-tingkatan tersebut terintegrasi ke dalam suatu sistem ajaran keberagamaan sehingga meniscayakan manusia menuju tujuan final, yakni jiwa yang siap menerima Tuhan, dan manusia pun mampu mengenal Tuhannya secara sempurna.

Di dalam konteks gerakan, ajaran-ajaran Syaikh Yusuf dapat menggerakkan suatu aktivitas sehingga berhasil membawa Islam sebagai agama yang maju dan berkembang di dalam masyarakat yang majemuk. Melekatnya dakwah Islam dengan tradisi, strata dan latar belakang masyarakat pada masa Syaikh Yusuf, adalah hal penting untuk diperhatikan, dan karenanya harus menjadi perhatian para juru dakwah sekarang ini, baik secara perorangan maupun institusi. Dalam berbagai literatur, dijelaskan bahwa perbedaan status sosial (ekonomi, pendidikan, lingkungan tempat tinggal) menjadikan intensitas dan derajat pemahaman keagamaan seseorang menjadi berbeda atau beragam. Bahkan latar belakang pendidikan yang tidak sama, perlakuan pendidikan dan faktor status juru dakwah, menyangkut kapasitas dan kapabilitas, kualitas dan profesionalitas, baik itu secara personal maupun institusional, ikut mempengaruhi kesadaran dan partisipasi keberagamaan masyarakat.

Konsep dakwah adalah suatu konsep penyelarasan antara etika dan dimensi estetika sekaligus, memiliki sandaran vertikal sekaligus sandaran horizontal. Corak dakwah Syaikh Yusuf yang tidak hitam-putih, langsung menyentuh aspek syari'at yang paling dalam (batin manusia), dan kemudian melaksanakan ajaran-ajaran syari'at dengan etika lahir-batin yang sangat dibutuhkan. Dengan pendekatan sufistik, Syaikh Yusuf mendapat simpati dari pelbagai lapisan masyarakat, raja, punggawa, dan rakyat jelata. Keberhasilan 


\section{Penutup}

ini tidak hanya terjadi di Nusantara, namun juga di mancanegara, tempat Syaikh Yusuf pernah menyebarkan ajaran dan dakwahnya.

Dalam sejarah perjalanan dakwah Islam di Nusantara, keberhasilan juru dakwah Islam masa-masa awal dan selanjutnya bertitik tolak dari penerapan etika religius serta pandangan filsafat hidup masyarakat setempat. Mereka telah menunjukkan keberhasilannya di dalam proses dakwah Islam dari masa ke masa. Dalam berdakwah, Syaikh Yusuf telah menunjukkan metode dakwah yang sesuai dengan konteks lokal, sedangkan contoh yang digunakannya tidak terlepas dari etika religius. Selain itu, dalam prosesnya, Syaikh Yusuf juga menunjukkan kapasitas dirinya sebagai seorang ulama sekaligus intelektual yang memiliki pengalaman dan pandangan luas akan dunia keilmuan Islam. Hal ini dapat dilihat dari pengalaman belajar serta rujukan-rujukan yang digunakannya ketika menjelaskan ajaran Islam di dalam karya-karyanya.

Dalam konteks dakwah Islam di Indonesia, kajian tentang etika religius Syaikh Yusuf dapat menjadi acuan yang perlu dikembangkan guna merumuskan ulang paradigma-paradigma filsafat dakwah yang lebih baik, misalnya dakwah etis dalam kaitannya dengan masyarakat non-Islam. Jika mengingat dunia global dan interaksi masyarakat yang makin intensif dalam memenuhi kebutuhan hidup, tentunya masyarakat membutuhkan pandangan dan sikap yang lebih bersahabat, memberi kenyamanan dan ketenangan. Karena itu, etika religius penting dipraktikkan di dalam kehidupan sehari-hari, terutama dalam proses dakwah Islam.

Etika religius Islam yang dikembangkan oleh Syaikh Yusuf merupakan ajaran-ajaran luhur ketuhanan yang sesuai dengan pandangan-pandangan universal pemikir-pemikir non-muslim lainnya yang juga menaruh perhatian besar pada etika religius. Persamaan dari seluruh pemikir etika religius walaupun berbeda 
agama adalah bahwa etika hidup yang dikembangkan dalam masyarakat memiliki tanggung jawab kepada sesama individu dalam masyarakat sekaligus tanggung tawab kepada Tuhan. Hal ini jelas berbeda dengan pandangan filsafat yang hanya menekankan etika dalam kaitannya dengan tanggung jawab di kehidupan dunia saja, tanpa membicarakan tanggung jawabnya di akhirat. Penekanan dalam etika religius adalah pada pandangan dunia yang komprehensif, yaitu dunia kini yang ditempati dan dunia yang akan datang. Pemahaman komprehensif inilah yang sebenarnya dirindukan oleh masyarakat modern yang tampaknya mulai haus akan unsur-unsur spiritual. 


\section{DAFTAR PUSTAKA}

Abdullah, Irwan. 2006. Konstruksi dan Reproduksi Kebudayaan. Yogyakarta: Pustaka Pelajar.

Abdullah, M. Amin. 2006. Islamic Studies di Perguruan Tinggi, Pendekatan Integratif-Interkonektif. Yogyakarta: Pustaka Pelajar. . 2004. Studi Agama, Normativitas atau Historisitas? Yogyakarta: Pustaka Pelajar.

Abdullah, M. Yatimin. 2006 Studi Etika. Jakarta: PT. Raja Grafindo Persada.

Abduh, Muhammad. 2006. Madza Ya’ni Intimaa’i lid Dakwah. Terj. Ulil Bahruddin. Jakarta: Robbani Press.

Abineno, J.L.Ch. 1994. Sooren Kierkegaard, Filsuf, Religius, dan Teolog. Jakarta: BPK Gunung Mulia.

Abu Riddah, M. Abdu al Hadi. 1997. "Razail al Kindi al Falsafiyyah, Dar al-Fikr al Arabi”. Dalam Nurcholis Madjid, Khazanah Intelektual Islam. Bandung: Bulan Bintang.

Ahmad, Mustaq. 2006. Business Ethics in Islam. Jakarta: Pustaka al-Kautsar.

Ahmad, Muhammad. 1982. "Hubungan Gowa dengan Aceh dalam Proses Islamisasi Kerajaan Bugis-Makassar”. Dalam Andi 
Rasdiyanah (ed.). Bugis-Makassar dalam Peta Islamisasi Indonesia, Selayang Pandang tentang Beberapa Aspek. Ujung Pandang: IAIN Alauddin.

Al-Ghazali, Imam. 2003. Ihya' Ulumiddin. Jilid I-IX. Semarang: Asy Syifa'.

. 2005. Al-Halal wal Haram. Saduran Indonesia oleh Muslih Ziedan. Surabaya: Amelia.

. 2007. Kimiyyah al Sa'adah wal Mawaidz fi al Ahadist al Qudsiyyah (terj.). Jakarta: Serambi Ilmu.

. 2007. Bidayatul Hidayah (terj.). Jakarta: Khatulistiwa Press.

.tt. Laysa minal Islam, asy Syariah al Islamiyyah Ahdafun wa Manahij (terj.) Solo: Pustaka Mantiq.

. 2007. Majmuah Rasail al Ghazali (terj). Yogyakarta: Pustaka al Furqan.

Ali Engineer, Asghar. 2003. Islam dan Teologi Pembebasan. Yogyakarta: Pustaka Pelajar.

Ali, Fachry dan Bahtiar Effendi. 1986. Merambah Jalan Baru Islam. Bandung: Mizan.

Al-qur'an dan Terjemahnya. tt. Semarang:PT. Toha Putra.

Amahzun, Muhammad. 2004. Manhajun Nabiyy fid Da'wah min Khilalis Sirah ash Shahihah al Ma'rifah, at-Tarbiyah, athThakhtith, at-Tanzhim. Edisi Indonesia. Manhaj Dakwah Rasulallah. Jakarta: Qisthi Press.

Aqil Siraj, Said. 2006. Tasawuf sebagai Kritik Sosial. Bandung: Mizan.

Armstrong, Karen. 2004. Islam: A Short Histor y (Terj.). Jakarta: Ikon Teralitera. 


\section{Daftar Pustaka}

. 2007. Holy War: The Crusades and Their Impact on Today's World. (terj.). Jakarta: PT. Serambi Ilmu Semesta.

Azra, Azyumardi. 1994. Jaringan Ulama Timur Tengah dan Kepulauan Nusantara Abad XVII dan XVIII. Bandung: Mizan.

Althuser, Louis. 2007. Lenin and Philosophy, and Other Essays (terj.) Yogyakarta: Resist Book.

Amril, M., 2002. Etika Islam, Telaah Pemikiran Filsafat Moral Raghib Al-Isfahani. Yogyakarta: Pustaka Pelajar.

Amir, Andi Rasdiyanah. 1982. Bugis-Makassar dalam Peta Islamisasi di Indonesia. Ujungpandang: IAIN Alauddin. Aristoteles. 1999. Nicomachean Ethics. London:Prentice Hall. . 1998. The Metaphysic. London: Penguin Group. . 2007. Aristoteles. Jakarta: PT. Elex Media Komputindo.

Awn, Peter J. 2007. Satan's tragedy and Redemption (terj.). Yogyakarta: Optimus..

Bacon, Francis. 1861. The Advancement of Learning. Heron Books.

Banani, Amin dkk. 2001. Poetry and Mysticism in Islam, the Heritage of Rumi (terj.) Surabaya: Risalah Gusti.

Bakti, Andi Faisal. 2006. Islam and Nation Formation in Indonesia. (terj.). Jakarta: Churia Press.

Basit, Abdul. 2006. Wacana Dakwah Kontemporer. Yogyakarta: Pustaka Pelajar.

Beekun, Rafik Issa. 2004. Islamic Business Ethics (terj.). Yogyakarta: Pustaka Pelajar. 
Bentounes, Khaled. 2003. Le Soufisme Coeur de L'Islam (terj.) Yogyakarta: Pustaka Sufi.

Beuken, Wim, Josef Kuschel, Karl et.all. 2003. Religion as A Source of Violence? (terj.). Yogyakarta: Pustaka Pelajar.

Bernadib, Imam. 2002. Filsafat Pendidikan. Yogyakarta: Adicita. Bertens, K. 2002. Etika. Jakarta:PT. Gramedia Pustaka Utama.

Biddiss, Michael D. 1977. The Age of the Masses Ideas an Society in Europe since 1870. England: Penguin Books.

Bochenski, J.M. 2006. “Apakah Sebenarnya Berpikir”. Dalam Jujun S. Suria Sumantri. Ilmu dalam Perspektif. Jakarta: Yayasan Obor Indonesia.

Bretal, Robert. 1947. A Kierkegaard Anthology. New Jersey: Princeton University Press.

Chittick, William C. 2002. Sufism: A Short Introduction (terj.). Bandung: Mizan.

Daldjoeni, N. 2006. "Hubungan Etika dengan Ilmu”. Dalam Jujun S. Suria Sumantri. Ilmu dalam Perspektif. Jakarta: Yayasan Obor Indonesia.

Dangor, S., Yusuf Da Costa, Achmad Davis. 1994. The Foot Steps in the Companions: Sheikh Yusuf of Macassar 16261699) in Pages from Cape Muslim History. Cape Town: Cape Muslim Press.

Darini (al), Abdul Aziz. 2004. Thahatul Qulub wa Khudu'li Aallamil Ghuyub (terj.). Bandung: Mizan.

Darusman, Lukmanul Hakim. 2008. Jihad in two faces of Shariah, Case Studies of Sheikh Yusuf al Maqassary and Sheikh Daud al Fatani (Disertasi). Canberra, Australia: ANU, The Australian National University. 


\section{Daftar Pustaka}

Davis, W.M. 2006. "Kaidah-Kaidah Ilmu yang Masuk Akal: Suatu Dongeng tentang Pasang”. Dalam Jujun S. Suria Sumantri. Ilmu dalam Perspektif. Jakarta: Yayasan Obor Indonesia.

Departemen Pendidikan Nasional. 2005. Kamus Besar Bahasa Indonesia. Jakarta: Balai Pustaka.

Dirk, M.Div, Psy., D. Jerald F. 2006. The Abrahamic Faith: Juda'ism, Christianity, and Islam Similarities and Contrast (terj.). Jakarta: Serambi Ilmu Semesta.

Effendi, Djohan. 1985. "Adam dan Insan Kamil: Pandangan Iqbal tentang Manusia”. Dalam Dawam Rahardjo. Insan Kamil, Konsepsi Manusia Menurut Islam. Jakarta: Grafiti Pers.

El Jazairi, Abu Bakar Jabir. 1993. Minhajul Muslim (terj.). Bandung: Remaja Rosda Karya.

Ernst, Carl W. 2003. The Shambala Guide to Sufism (terj.) Yogyakarta: Pustaka Sufi. . 2003. Words of Ecstasy in Sufism (terj.). Yogyakarta: Putra Langit.

Elders' S.V.D., Leo J. 1990. The Philosophical Theology of St. Thomas Aquinas. Leiden: E.J. Brill.

Esposito, John L. 2002. What Everyone Needs to Know About Islam (terj.). Depok: Inisiasi Press.

Faizah dan Lalu Muchsin Effendi. 2006. Psikologi Dakwah. Jakarta: Prenada Media.

Fakhry, Majid. 1996. Ethical Theories in Islam (terj.). Yogyakarta: Pustaka Pelajar

Farid, Andi Zainal Abidin.1982. Lontara Sulawesi Selatan sebagai Sumber Informasi Ilmiah. Dalam Andi Rasdiyanah (ed.). Ujung Pandang: IAIN Alauddin. 
Fleming, S. J, T.V. 1949. Foundations of Philosophy. Sydney: The Shakespeare Head.

Foucoult, Michael. 2007. The Orders of Things. An Archeology of Human Science. Yogyakarta: Pustaka Pelajar.

Fuad, Hashem. 2005. Sirah Muhammad Rasulallah, Kurun Makah. Jakarta: Tama Publisher.

Furchan, Arief dan Maimun, Agus. 2005. Studi Tokoh, Metode Penelitian Mengenai Tokoh. Yogyakarta: Pustaka Pelajar.

Gadamer, Hans-Georg. 2004. Truth and Method (terj.). Yogyakarta: Pustaka Pelajar.

Gardiner, Patrick. 1998. Kierkegaard, A Very Short Introduction. New York: Oxford.

Geertz, Clifford. 1973. The Interpretation of Cultures. New York: Basic Books.

The Liang Gie. 1980. Kamus Logika. Edisi kedua. Yogyakarta: Karya Kencana. .2003. Sejarah Ilmu-Ilmu, dari Masa Kuno sampai Zaman Moderen. Yogyakarta: PUBIB Yogyakarta dan Sabda Persada.

Gilsenan, Michael. 1973. Saint and Sufi in Modern Egypt, an Essay in the Sociology of Religion. Oxford: Oxford at The Clarendon Press.

Great, The Alexander. 2007. Alexander The Great. Jakarta: PT. Elex Media Komputindo.

Green, Ronald M. 1988. Religion and Moral Reason. Oxford: Oxford University Press.

Hadi, P. Hardono. 1994. Epistemologi Filsafat Pengetahuan Kenneth T. Gallagher. Yogyakarta: Kanisius. 


\section{Daftar Pustaka}

Haikal, Muhammad Husein. 2005. Hayatu Muhammad (terj.). Jakarta: Litera AntarNusa.

Haeri, Syaikh Fadhlalla. 2003. The Element of Sufism. Yogyakarta: Tim Forstudia, Pustaka Sufi.

Hadzami, Sjafi'i. 1971. Taudihul Adillah, 100 Masalah Agama. Jilid 1-7. Kudus: Penerbit Menara Kudus..

Halim, Mahmud, Ali Abdul. 2004. Fiqhud Da'wah al Fardiyyah (terj.). Jakarta: Gema Insani..

Hamid, Abu. 2005. Syaikh Yusuf, Seorang Ulama, Sufi, dan Pejuang. Jakarta: Yayasan Obor Indonesia.

Hanafi, Hasan. 2007. Etika Global dan Solidaritas Kemanusiaan dalam Islam dan Humanisme, Aktualisasi Humanisme Islam di Tengah Krisis Universal. Yogyakarta: Penerbit IAIN Walisongo Semarang dan Pustaka Pelajar.

Harits, A. Busyairi. 2006. Dakwah Kontekstual, Sebuah Refleksi Pemikiran Islam Kontemporer. Yogyakarta: Pustaka Pelajar.

Haryatmoko. 2004. Etika Politik dan Kekuasaan. Jakarta: PT. Kompas Media Nusantara.

. 2003. Etika Politik dan Kekuasaan. Jakarta: Penerbit Buku Kompas.

Hazlitt, Henry. 2003. The Foundation of Morality (terj.). Jakarta: Pustaka Pelajar.

Hasymy, A. 1989. Sejarah Masuk dan Berkembangnya Islam di Indonesia, (Kumpulan Prasaran pada Seminar di Aceh). Bandung: PT. Alma'arif.

Hassan, Fuad. 2001. Stadium Generale. Bandung: Pustaka Jaya 
Hasan, Ahmad Rifai. 1985. "Manusia serta Dimensi dalam Pandangan Mutahhari”. Dalam Dawam Rahardjo, Insan Kamil, Konsepsi Manusia Menurut Islam. Jakarta: Grafiti Pers.

Hazrat, Inayat Khan. 2001. In the Eastern Rose Garden (terj.). Yogyakarta: Putra Langit.

Hegel, George Wilhelm Friedrich. 2007. The Philosophy of History (terj.). Yogyakarta: Pustaka Pelajar. . 1984. Lectures on the Philosophy of Religion (ed.). California: University of California Press. . 2002. Faith and Knowledge. (terj.). Yogyakarta: IRCiSoD.

Hiher, Gilbert. 2006. "Pikiran Manusia yang Tak Tertundukkan". Dalam Jujun S. Suria Sumantri. Ilmu dalam Perspektif. Jakarta: Yayasan Obor Indonesia.

Hitti, Philip. K. 2002. History of the Arabs (terj.). Jakarta: Serambi Ilmu Semesta.

Honer, Stanley M. dan Thomas C. Hunt. 2006. "Metode dalam Mencari Pengetahuan: Rasionalisme, Empirisme, dan Metode Keilmuan”. Dalam Jujun S. Suria Sumantri. Ilmu dalam Perspektif. Jakarta: Yayasan Obor Indonesia.

Hornby, AS, Wehmeir, Sally (ed.). 2005. Oxford Advanced Learner's Dictionary of Current English. Oxford.

Hujwiri (al), Ibnu Usman. 200o. The Kashf al Mahjub, The Oldest Persian Treatise on Sufism. (terj.). Yogyakarta: Pustaka Sufi.

Ilaihi, Wahyu dan Harjani Hefni. 2000. Pengantar Sejarah Dakwah. Jakarta: Kencana Predana Media. 


\section{Daftar Pustaka}

Iskandari (al), Ibnu Athaillah. 2006. Miftahul Falah wa Misbahul Arwah (terj.). Jakarta: PT. Serambi Ilmu Semesta. . 2007. Ataillah al-Qasd al-Mujarrad fi Ma'rifat al-Ism alMufrad (terj.). Jakarta: Serambi Ilmu.

Izutsu, Toshihiko. 1993. Ethico-Religious Concepts in the Qur'an (terj.). Yogyakarta: Tiara Wacana. .2003. God and Man in the Koran: Semantics of the Koranic Weltanschauung (terj.). Yogyakarta: Tiara Wacana.

. 1959. The Structure of the Ethical Terms in the Koran. Tokyo: Keio University, Studies in the Humanities and Social Relations.

Jailani, Abdul Qadir. 2007. Al Fath al-Rabbani wa al-Fayd alRahmani (terj.). Jakarta: Serambi Ilmu.

. 2007. Jalan Cinta al-Jailani (terj.). Jakarta: Diadi Media. . 2006. Adab al Suluk wa Tawasul ila Manazil al-Muluk (terj.). Jakarta: Pustaka al Furqan.

Jami, Maulana Abdurrahman. 2007. Nafahat al Uns min Hadharat al Quds. tp.

Jili, Abdul Karim, al. 2006. Al-Insan al-Kamil Fi Ma'rifatil Awail wal Awakhir (terj.) Jakarta: Serambi Ilmu

Johnson, Raynor C. 1969. A Religious Outlook for Modern Man. McGraw-Hill Book Company, New York.

Juziyah, Ibnu Qayyim. 2000. Al-Furuqun Nafisah baina Shifaatinnafsi ath-Thayyibah wal Khabitsati (terj.). Surabaya: Risalah Gusti.

Jum'ah Amin Abdul Azis. 1417H/1997. Ad-Dakwah, Qawaid wa Ushul. Cet. I. Iskandaria: Dar al-Da'wah. 
Kaelan, M.S. 2006. Perkembangan Filsafat Analitika Bahasa dan Pengaruhnya terhadap Ilmu Pengetahuan. Yogyakarta: Paradigma. . 2005. Metode Penelitian Kualitatif Bidang Filsafat. Yogyakarta: Paradigma.

. 2002. Filsafat Pancasila. Yogyakarta: Paradigma. . 1999. Etika Lingkungan. Yogyakarta: Paradigma.

Karraz, Abu Said, al. 2003. Al-Tariq Ailallah atau Kitab as-Sidq (terj.) Yogyakarta: Pustaka Sufi.

Kartanegara, Mulyadhi. 2007. Nalar Religius, Memahami Hakikat Tuhan, Alam, dan Manusia. Jakarta: Penerbit Erlangga.

Kattsoff, Louis O. 2004. Elements of Philosophy (terj.). Yogyakarta: Tiara Wacana.

Kant, Immanuel. 2005. Critique of Practical Reason (terj.). Yogyakarta: Pustaka Pelajar. . 1990. Critique of Pure Reason. Translated by J.M.D. Meiklejohn., New York: Promotheos Books.

Kartodirjo, Sartono, dkk. 1975. Sejarah Nasional Indonesia Jilid III. Jakarta: Departemen Pendidikan dan Kebudayaan. 1992. Pengantar Sejarah Indonesia Baru: 1500-19oo, dari Emporium sampai Imperium Jilid 1. Jakarta: Penerbit Gramedia Pustaka Utama.

Keraf, A. Sony. 2002. Etika Lingkungan. Jakarta: Penerbit Buku. . 2006. Etika Lingkungan. Jakarta: PT. Kompas Media Nusantara.

Kern, R.A. 1993. I Laga Ligo. Catalogus der Boegineesche tot den I Laga Ligo-cyclus behorende handschriften bewaard in het Legatum Warnerianum te Leiden alsmede in andre 


\section{Daftar Pustaka}

Europeesche bibliotheken. Leiden, Legatum Warnerianum, 1939., Catalogus van de Boeginese, tot de I La Galigo-cyclus behorende hanschriften van Jajasan Matthes (Matthes-stichting) te Makassar (Indonesiae), Jajasan Matthes, 1954., Een episode uit het I Lagaligo epos, Bijdragen tot de Taal-Land- en Volkenkunde, 1961. (Edisi terjemahan ini adalah hasil terjemahan beberapa bagian dari Karya-karya tersebut di atas).

Kierkegaard, Sooren. 1955. On Authority and Revelation. New Jersey: Princeton University Press.

Khan, Ali Mahdi.1999. The Elements of Islamic Philosophy (terj.) Bandung. tp.

Kristy, Retno (ed). 2007. Plato, Pemikir Etika dan Metafisika. Jakarta: PT. Gramedia.

Kurdi (al), M. Amin. 2003. Tanwirul Qulub fi Muamalati Allamin Ghuyub (terj.). Jakarta: Penerbit Hikmah.

Lasiyo dan Yuwono. 1985. Pancasila, Pendekatan secara Kefilsafatan. Yogyakarta: Penerbit Liberti.

Latif, Dochak. 2006. Etika Bisnis: Antara Norma dan Realita. Surakarta: Muhammadiyah University Press.

Lambton, A.K.S. 2008. "Benturan Peradaban: Kekuasaan, Legitimasi, dan Ketersempurnaan”. Dalam Andri Rosadi, Hitam Putih FPI (Front Pembela Islam). Yogyakarta: Nun Publisher.

Lubis, Nabilah. 1996. Syaikh Yusuf al-Taj al-Makassari, Menyingkap Intisari Segala Rahasia. Bandung: Mizan.

Latif, Halilintar. 2004. Bissu, Pergulatan dan Peranannya di Masyarakat Bugis. Depok \& Makassar: Desantara dan Latar Nusa. 
Lings, Martin. 2004. What is Sufism (terj.). Yogyakarta: Futuh Printika.

2007. Muhammad: His life Based on the Earliest Source (terj.). Jakarta: PT. Serambi Ilmu Semesta.

Machfoeld, Ki Moesa A. 2004. Filsafat Dakwah, Ilmu Dakwah dan Penerapannya. Jakarta: Bulan Bintang.

Madjid, Nurcholish. 2006. Islam Doktrin dan Peradaban. Jakarta: Paramadina.

. 2007. Konsep Islam tentang Manusia dan Implikasinya terhadap Apresiasi Muslim Mengenai Hak-Hak Sipil dan Politik dalam Islam dan Humanisme, Aktualisasi Humanisme Islam di Tengah Krisis Universal. Yogyakarta: Penerbit IAIN Walisongo Semarang dan Pustaka Pelajar.

Mahmud, Ahmad. 2004. Ad-Dakwah Ila al-Islam (terj.). Bogor: Pustaka Thariqul Izzah.

Mahmud, Ali Abdul Halim. 1992. Fiqhud Dakwah al-Fardiyyah (terj.). Jakarta: Gema Insani Press.

Makki, Abu Thalib, al. 2005, Qu tul Qulub, Pasal ke-33, Dzikir Da'aim al-Islam al-Khams Allati Buniya Alaih, (terj.). Bandung: Mizan.

Maliki, Sayyid Muhammad Alwi, al. 2005. Al-Insan al-Kamil Muhammad Saw. (terj.). Surabaya: Bina Ilmu.

Mangemba, H.D. 2002. Takutlah Pada Orang Jujur, Mozaik Pemikiran. Yogyakarta: Lembaga Penerbitan Universitas Hasanuddin Makassar Kerja sama dengan Pustaka Pelajar. 


\section{Daftar Pustaka}

Manyambeang, Abd. Kadir dkk. 1990. Lontarak Syaikh Yusuf Suatu Analisis Filologi Kultural. Ujungpandang: Universitas Hasanudin.

Mas'ud, Abdurrahman. 2004. Intelektual Pesantren, Perhelatan Agama dan Tradisi. Yogyakarta: LKiS.

Maududi, Abul a'la. 2004. Islam's Way of Life, Islam Kaffah (terj.). Jakarta: Cahaya Hikmah.

Marx, Karl. 2004. Poverty of Philosophy (terj.). Jakarta: Hasta Mitra.

Mastuki, HS dan M. Ishom El Saha, (ed.). 2003. Intelektualisme Pesantren. Jakarta: Diva Pustaka.

Mattulada. 1983. "Islam di Sulawesi Selatan”. Dalam Taufik Abdullah (ed.). Agama dan Perubahan Sosial. Jakarta: LP3ES.

. 1995. Latoa, Suatu Lukisan Analitis Antropologi Orang Bugis. Ujung Pandang: Hasanuddin University.

Martin, O.P., Vincent. 2003. Filsafat Eksistensialisme: Kerkegaard, Sartre, Camus. Yogyakarta: Pustaka Pelajar.

Masyharuddin. 2007. Pemberontakan Tasawuf, Kritik Ibnu Taymiyah atas Rancang Bangun Tasawuf. Kudus: STAIN Press.

Mubarak, Ahmad. 2002. Psikologi Dakwah. Cet. ke-3. Jakarta: Pustaka Firdaus.

Mudhafir, Ali. 2001. Kamus Filsuf Barat. Yogyakarta: Pustaka Pelajar.

Muhadjir, Noeng. 1996. Metodologi Penelitian Kualitatif. Yogyakarta: Rake Sarasin. 
Muhiddin, Asep. 2002. Dakwah dalam Perspektif al-Qur'an. Bandung: Pustaka Setia.

Muthahhari, Murtadha. 2004. Falsafatul Akhlak (terj.). Jakarta: Al-Huda.

Muhammad, Abdul Kadir. 2006. Etika Profesi Hukum. Bandung: PT. Citra Aditya Bakti.

Mulyati, Sri. 2006. Tasawuf Nusantara, Rangkaian Mutiara Sufi Terkemuka. Jakarta: Kencana.

Mouly, George. 2006. "Perkembangan Ilmu”. Dalam Jujun S. Suria Sumantri. Ilmu dalam Perspektif. Jakarta: Yayasan Obor Indonesia.

Nada, Abdul Aziz bin Fathi Sayyid. 2005. Mausu'ah al-Adab alIslamiyyah al-Murattabah ala al-Huruf al-Hija'iyyah (terj.). Jakarta: Maghfirah Pustaka.

Nasier, Abdul. 2005. "Saya Asal Macassar”. Dalam Ramadhan KH dan Fitria Sari (eds.). Jakarta: Yayasan Obor Indonesia.

Nasr, Sayyed Hossein. 2003. Islam: Religion, History, and Civilization (terj.). Surabaya: Risalah Gusti.

Nasution, Harun. 1973. Falsafah dan Mistisisme dalam Islam. Jakarta: Bulan Bintang.

Nawawi, Hadari. 2005. Metode Penelitian Bidang Sosial. Yogyakarta: Gadjah Mada University Press.

Nazir, Mohammad. 1983. Metode Penelitian. Ghalia Indonesia.

Naysaburi, Imam Al-Qusyairi, An. 2006. Risalah Qusyairiyah. Surabaya: Risalah Gusti.

Nietzsche, Friedrich. 2002. Beyond Good and Evil Prelude, Menuju Filsafat Masa Depan (terj.). Yogyakarta: Ikon Teralitera. 


\section{Daftar Pustaka}

Nicholson, R.A. 2003. Studies in Islamic Mysticism (terj.). Bandung: Mizan.

Nuh, Sayyid Nuh. 2004. Fiqh Dakwah al-Fardiyah fi al-Manhaj al-Islami. (terj.). Jakarta. Indonesia Era Intermedia.

Oesman, Moerad. 1982. "Masuknya Islam di Indonesia Bagian Timar dan Hubungannya dengan Aceh Darussalam”. Dalam Andi Rasdiyanah (ed.). Bugis-Makassar dalam Peta Islamisasi Indonesia, Selayang Pandang tentang Beberapa Aspek. Ujung Pandang: IAIN Alauddin.

Pelras, Christian. 2005. The Bugis (terj.). Jakarta: Forum JakartaParis EFEO.

Permata, Ahmad Norma (ed.). 1996. Perennialisme: Melacak Jejak Filsafat Abadi. Yogyakarta: Tiara Wacana.

Peterson, Michael et.all. 1996. Philosophy of Religion. New York: Oxford University Press.

Peursen, C. A. van. 1988. Cultuur in Stroomversnelling-een Geheel Bewerkte Uitgave Van (terj.). Yogyakarta: Kanisius.

Philips, Christopher. 2001. Socrates Café, A Fresh Taste of Philosophy. New York: W.W. Norton and Company.

Prasetia, Heru. 2007. Lintas Batas Identitas, Posisi dan Artikulasi Komunitas Tolotang Sulawesi Selatan dalam Hak Minoritas, Multikulturalisme dan Dilema Negara Bangsa. Yogyakarta: Interseksi Foundation-TIFA.

Poedjawijatna, I.R. 2004. Tahu dan Pengetahuan. Jakarta: Rineka Cipta. . 2003. Etika Filsafat Tingkah Laku. Jakarta: Rineka Cipta.

Pritchard, E.E.Evan. 1973. The Sanusi of Cyrenaica. Oxford: Oxford at The Clarendon Press. 
Putuhena, M. Shaleh. 2007. Historiografi Haji Indonesia. Yogyakarta: $L K i S$.

Purwadaksi, Ahmad. 2001. Ratib Samman dan Hikayat Syeikh Muhammad Samman. Jakarta: UI Press.

Poespoprodjo, W. 1998. Filsafat Moral, Kesusilaan dalam Teori dan Praktek. Bandung: Pustaka Grafika.

Qardhawi, Yusuf. 2004. Al-Iman wa Hayat (terj.). Yogyakarta: Mitra Pustaka.

Qahtani, Saad ibn Ali ibn Wahf, al. 2005. Muqawwimat Adda'iyyah an Najih fi Dhau' al Kitab wa as Sunnah, Mafhum wa Nazhar wa Tatbiq (terj.). Jakarta: Qisthi Press.

Quinn Patton, Michael. 2006. How to Use Qualitative Methods in Evaluation (terj.). Yogyakarta: Pustaka Pelajar.

Qutb, Sayyid. 1986. Fiqhu ad-Da'wah, Maudhu'at fi ad-Da'wah wa al-Harakah (terj.). Jakarta: Pustaka Amani.

Rachels, James. 2004. The Elements of Moral Philosophy (terj.). Yogyakarta:Kanisius

Radhakrisnan, S. 2003. Religion and Society (terj.). Denpasar: Mabhakti.

Rahman, Nurhayati., dkk (eds.). 2003. La Galigo: Menelusuri Jejak Warisan Sastra Dunia. Makassar: UNHAS.

Ramadlhan Al-Buthy, Muhammad Sa’id. 2006. Al Jihad fil Islam, Kaifa Nafhamuhu wa Kaifa Numarisuhu (terj.). Jakarta: al Markaz Publishing.

Rasdiyanah, Andi (ed.). 1982. Bugis-Makassar dalam Peta Islamisasi Indonesia, Selayang Pandang tentang Beberapa Aspek. Ujung Pandang: IAIN Alauddin. 


\section{Daftar Pustaka}

Rawls, John. 2006. A Theory of Justice (terj.). Yogyakarta: Pustaka Pelajar.

Ricklefs, M.c. 2007. A History of Modern Indonesia (terj.). Yogyakarta: Gadjah Mada University Press.

Roth, John K. 2003. The Problems of the Contemporary Philosophy of Religion (terj.). Yogyakarta: Pustaka Pelajar.

Rudner, Richard S. 2006. "Perbedaaan antara Ilmu-Ilmu Alam dan Ilmu-Ilmu Sosial”. Dalam Jujun S. Suria Sumantri. Ilmu dalam Perspektif. Jakarta: Yayasan Obor Indonesia.

Russel, Bertrand. 2006. "Fakta, Kepercayaan, Kebenaran, dan Pengetahuan”. Dalam Jujun S. Suria Sumantri. Ilmu dalam Perspektif. Jakarta: Yayasan Obor Indonesia.

Rosadi, Andri. 2008. Hitam Putih FPI (Front Pembela Islam). Jakarta: Nun Publisher.

S.Praja, Juhaya. 2005. Aliran-Aliran Filsafat dan Etika. Jakarta: Prenada Media.

. 2003. Filsafat dan Etika. Jakarta: RajaGrafindo Persada.

Salam, Solichin. 2004. Syaikh Yusuf "Singa dari Gowa" (Ulama

Kaliber Internasional). Jakarta: Yayasan Pembina Generasi Muda Indonesia bekerja sama dengan Gema Salam.

Sarraj, Abu Nashr. 2002. Al-Luma' (Lajnah Nasyr at-Turats ashShufi (terj.). Jakarta: Risalah Gusti.

Sen, Peter R. 2006. “Struktur Ilmu”. Dalam Jujun S. Suria Sumantri. Ilmu dalam Perspektif. Jakarta: Yayasan Obor Indonesia.

Sewang, Ahmad, M. 2005. Islamisasi Kerajaan Gowa. Jakarta: Yayasan Obor Indonesia. 
Schimmel, Annemarie. 2008. I Am Wind, You Are Fire. (terj.). Bandung: Mizan. . 2000. Mystical Dimension of Islam (terj.). Yogyakarta: Pustaka Firdaus.

Shihab, Alwi. 2000. Al-Tashawwuf al-Islami wa Atsaruhu fi alTasawwuf al-Indunisi al-Mu'ahsir (terj.). Bandung: Mizan.

Sina, Ibnu. 1997. Itsbat al-Nubuwwat li Ibn Sina (ed.). Bandung: Bulan Bintang.

Siti Aminah, Wiwin, (ed.). 2006. Sejarah Teologi dan Etika Agama. Yogyakarta: Pustaka Pelajar.

Sirriyyeh, Elizabeth. 2003. Sufis anti Sufis (terj.). Yogyakarta: Pustaka Sufi.

Siba'i, Mustafa, as. 2007. As-Sirah an-Nabawiyyah (terj.). Jakarta: Studia Press.

Smart, Ninian. 1999. World Philosophies. New York: Rontledge. Smith, Linda dan William Raeper. 2000. A Beginner Guides to Ideas (terj. ).Yogyakarta: Kanisius.

Soejadi. 2008. Mensyukuri Karunia Allah. Jakarta: Pustaka Pergaulan.

Soepardan, Suryani dan Dadi Anwar. 2005. Etika Kebidanan dan Hukum Kesehatan. Jakarta: Penerbit buku Kedokteran, EGC.

Sugiharto, I Bambang dan Rachmat W, Agus. 2000. Wajah Baru Etika dan Agama. Yogyakarta: Kanisius.

Supadjar, Damardjati., 2001, Filsafat Sosial Serat, Sastra Gending. Yogyakarta: Fajar Pustaka Baru. 


\section{Daftar Pustaka}

Suria Sumantri, Jujun. 1993. Filsafat Ilmu, Sebuah Pengantar Populer. Jakarta: Pustaka Sinar Harapan. . 2006. Ilmu dalam Perspektif. Jakarta: Yayasan Obor Indonesia

Suryo, Joko. 2006. Sumber-Sumber Sejarah: Untuk Penelitian Sejarah Indonesia, Sebuah Pengantar. Surabaya: Perpustakaan Nasional RI, Penyajian Materi Metode Penelitian Sejarah di Jurusan Sejarah Universitas Airlangga.

Suparta dan Hefni (ed.). 2003. Metode Dakwah. Jakarta: Prenada Media.

Suseno, Franz Magniz. 1987. Etika Dasar Masalah-Masalah Pokok Filsafat Moral. Yogyakarta: Kanisius. . 1992. Berfilsafat dari Konteks. Jakarta: Gramedia. . 1997. 13 Tokoh Etika. Yogyakarta: Kanisius. . 20oo, 12 Tokoh Etika Abad Ke-2o. Yogyakarta: Kanisius. . 2006. Menalar Tuhan. Yogyakarta: Kanisius. . 2006. Etika Abad Kedua Puluh. Yogyakarta: Kanisius.

Sulthon, Muhammad. 2003. Menjawab Tantangan Zaman, Desain Ilmu Dakwah Kajian Ontologis, Epistemologis, dan Aksiologis. Semarang: Pustaka Pelajar dan Walisongo Press.

Syamsuddin, Din. 200o. Etika Agama dalam Membangun Masyarakat Madani. Jakarta: Logos wacana ilmu.

Syukur, HM. Amin, Muhayya, Abdul. (ed.). 2001. Tasawuf dan Krisis. Semarang: Pustaka Pelajar dan IAIN Walisongo.

Syukur, M Amin. 2004. Tasawuf Sosial. Yogyakarta: Pustaka Pelajar. 
Syukur, Suparman. 2004. Etika Religius. Yogyakarta: Pustaka Pelajar.

Syuwaikh, Adil Abdullah al-Laili, Asy. 2006. Musafir fi Qithratid Dakwah (terj.). Jakarta: Rabbani Press.

Syarbashi, Ahmad, Asy. 2001. Yas Alunaka fiddin wal Hayah (terj.). Jakarta: PT. Lentera Basritama.

Sou'yb, Joesuf. 1979. Sejarah Khulafaur Rasyidin. Jakarta: Bulan Bintang.

Sofwan dkk. 2004. Islamisasi di Jawa. Yogyakarta: Pustaka Pelajar.

Sultan, Sahib. 1989. Allah dan Jalan Mendekatkan Diri KepadaNya dalam Konsepsi Syaikh Yusuf. Jakarta: Penerbit al Quswa.

Smith, Margareth. 2007. Studies in Early Mysticism in the Near and Middle East (terj.). Jakarta: Gaya Media Pratama.

Syah, Omar Ali. 2004. Sufism as Theraphy (terj.). Yogyakarta: Futuh Printika.

Teichman, Jenny. 1998. Social Ethics: A Student's Guide (terj.). Yogyakarta: Kanisius.

Titus, Harold H. dkk. 1979. Persoalan-Persoalan Filsafat. Jakarta: Bulan Bintang.

Thompson, Mel. 2006. Ethics. England: Hodder Headline.

Thomte, Reidar. 1949. Kierkegaard's Philosophy of Religion. New Jersey: Princeton University Press.

Trimingham, J. Spencer. 1999. Madzhab Sufi (terj.). Bandung: Pustaka Bandung. . 1971. The Sufi Orders in Islam. Oxford: Oxford University Press. 


\section{Daftar Pustaka}

Tudjimah. 1997. Syaikh Yusuf Makasar, Riwayat dan Ajarannya. Jakarta: UI Press.

Thomas W. Arnold. 1981. The Preaching of Islam (terj.). Jakarta: Wijaya.

Umr, Abdurrahman bin Hamad, al. 2001. Hakikat Dakwah Syaikh Muhammad bin Abdul Wahhab. Terj. Abdul Rosyad Shiddiq. Jakarta: Darul Falah.

Usman, Sunyoto. 1998. Pembangunan dan Pemberdayaan Masyarakat. Yogyakarta: Pustaka Pelajar.

W. Elrod, John. 1981. Kierkegaard and Christendom. Princeton University Press.

Van Dalen, Deobold B. 2006. "Ilmu-Ilmu Alam dan Ilmu-Ilmu Sosial: Beberapa Perbedaan”. Dalam Jujun S. Suria Sumantri. Ilmu dalam Perspektif. Yogyakarta: Yayasan Obor Indonesia.

Van Ufford, Philip Quarles. 2003. Kritik Moral Pembangunan. Yogyakarta: Penerbit Kanisius.

Watt, W. Montgomery. 1968. What is Islam? Washinton: Frederick A. Praeger Publishers, New York.

Wibisono, Koento.1996. Filsafat Ilmu. Yogyakarta: Fakultas Filsafat UGM- Penerbit Liberti.

Wilardjo, L. 2006. "Ilmu dan Humaniora”. Dalam Jujun S. Suria Sumantri. Ilmu dalam Perspektif. Jakarta: Yayasan Obor Indonesia.

Yunus, Mahmud. 1989. Kamus Arab-Indonesia. Jakarta: Mahmud Yunus wa Zuriyyah.

Yusuf al Makassari, Syaikh. 1997. "Al-Barakat al Sailaniyyah minal Futuhat al Rabbaniyyah”. Dalam Tudjimah (ed.). Syaikh 
Yusuf, Riwayat Hidup, Karya, dan Sejarahnya. Jakarta:

UI Press.

. 1997. Bidayatul Mubtadi. Dalam Tudjimah (ed.). Jakarta:

UI Press.

. 1997. Al Fawaih al Yusufiyyah fi Bayan Tahqiq al Sufiyyah. Dalam Tudjimah (ed.). Jakarta: UI Press.

. 1997. Hasyiah fi Kitab al Anbah fi I'rabi la Ilaha Illallah.

Dalam Tudjimah (ed.). Jakarta: UI Press.

. 1997. Kifiyat al Munji wal Itsbat bi al Hadist al Qudsiyyah.

Dalam Tudjimah (ed.). Jakarta: UI Press.

. 1997. Matalib Salikin. Dalam Tudjimah (ed.). Jakarta: UI Press.

. 1997. Al Nafhah al-Saylaniyah. Dalam Tudjimah (ed.). Jakarta: UI Press.

. 1997. Qurratul Ain. Dalam Tudjimah (ed.). Jakarta: UI Press.

. 1997. Sirrul Asrar. Dalam Tudjimah (ed.) Jakarta: UI Press.

. 1997. Surah. Dalam Tudjimah (ed.). Jakarta: UI Press.

. 1997. Taj al Asrar fi tahqiq Masyarib al Arifin. Dalam Tudjimah (ed.). Jakarta: UI Press.

. 1997. Zubdat al Asrar fi Tahqiq Ba'dha Masyarib al Akhyar. Dalam Tudjimah (ed.). Jakarta: UI Press.

. 1997. Fathu Kayfiyyat al Dzikr. Dalam Tudjimah (ed.). Jakarta: UI Press.

. 1997. Daf'ul Bala. Dalam Tudjimah (ed.). Jakarta: UI Press.

. 1997. Hadzihi Fawaid Azhimat al Dzikr Lailaha Illalah.

Dalam Tudjimah (ed.). Jakarta: UI Press. 


\section{Daftar Pustaka}

. 1997. Muqaddimah al Fawaid Allati ma Labudda minal Aqaid. Dalam Tudjimah (ed.). Jakarta: UI Press.

. 1997. Tahsilul Inayat wa al Hidayat. Dalam Tudjimah (ed.). Jakarta: UI Press..

. 1997. Ghayatul Ikhtisar wa Nihayat al Intizar. Dalam Tudjimah (ed.). Jakarta: UI Press.

. 1997. Tuhfatul Amr fi Fadlilat al Dzikr. Dalam Tudjimah (ed.). Jakarta: UI Press.

. 1997. Tuhfat al Abhar li Ahlil Asrar. Dalam Tudjimah (ed.). Jakarta: UI Press.

. 1997. Al Washiyyat al Munjiyyat an Mudahar al Hijaib. Dalam Tudjimah (ed.). Jakarta: UI Press.

\section{Naskah/Manuskrip, Jurnal, dan Koran, Lain-Lain}

Azra, Azyumardi. "Syekh dan Ulama Nusantara". Dalam Paket Siaran Ramadhan TV One. 16 September 2008.

. "Radikalisme Kelompok Islam di Indonesia”. Jakarta: dalam Harian Kompas. 27 Juli 2007.

Baqi, Muhammad Fu'ad Abdul, al. t.t. Al-Mu’jam al-Mufahras li al-Fazh al-Qur'an. Jakarta: Naskah yang ditunjukkan oleh PPS UIN Syarif Hidayatullah.

Cawidu, Harifuddin. 1994. Peringatan 300 tahun Mendaratnya Syaikh Yusuf Al- Khlwaty Al-Makassary di Afrika Selatan. Makalah Seminar Nasional. Ujung pandang: Universitas Hasanuddin.

Kaelan, M.S. 2007. Kesesatan Epistemologi di Era Reformasi dan Revitalisasi Nation-State. Yogyakarta: Pidato 
Pengukuhan Jabatan Guru Besar pada Fakultas Filsafat Universitas Gadjah Mada.

Kompas. 16 dan 18 Maret 20o8, “Jejak Syaikh Yusuf di Cape Town” dalam Rangka Kunjungan Kenegaraan Presiden RI Susilo Bambang Yudoyono.

Kusmaryanto, CB. Etika Levinas. t.t. Makalah/Bahan kuliah). Program Pascasarjana Univesitas Gadjah Mada Yogyakarta. Tidak diterbitkan.

Mangemba, H.D. 1994. Syaikh Yusuf Tuanta Salammaka Pahlawan Nasional, Penyebar Agama Islam dan Pejuang Hak Asasi Manusia. Ujung Pandang: Makalah Seminar Nasional diselenggarakan oleh Universitas Hasanuddin.

Mappangara, Suriadi. "Bugis-Makassar dalam Lintasan Sejarah”. Dalam Kompas. 16 Januari 2009.

Maqdisi, Faidullah al-Hasani, al. t.t. Fathurrahman Litalibil Qur'an. (Naskah Arab). Peny. M. Dahlan.

Mustari. 1995. Studi Metodologi Dakwah Yayasan Paramadina Jakarta. Makassar: Skripsi tidak diterbitkan pada Fakultas Dakwah dan Komunikasi UIN Alauddin Makassar.

- 2000. Pengaruh Dakwah terhadap Kesadaran Lingkungan Hidup (Studi Kasus pada Beberapa Majelis Ta'lim Kota Makassar). Makassar: Tesis tidak diterbitkan pada Jurusan Pendidikan Ilmu Sosial, PPS Universitas Negeri Makassar.

Naskah Arab/Manuskrip, Perpustakaan Nasional bundel A. 101. Peny. Sanwani, Jakarta, 1186 H/1772 M.

Naskah Arab/Manuskrip dalam Solichin Salam. 1994. 


\section{Daftar Pustaka}

Naskah Arab/Manuskrip dalam Nabilah Lubis. 1996.

Naskah Arab/Manuskrip. Matalib Salikin. Perpustakaan Nasional Bundel A. 101. Peny. Sanwani, Jakarta, 1186 H./1772 M.

Naskah Arab/Manuskrip. Al Nafhah al Saylaniyah. Perpustakaan Nasional Bundel A. 101. Peny. Sanwani, Jakarta, 1186 H./1772 M.

Naskah Arab/Manuskrip. Qurratul 'Ain. Perpustakaan Nasional Bundel A. 101. Peny. Sanwani, Jakarta, 1186 H./1772 M.

Naskah Arab/Manuskrip. Sirrul Asrar. Perpustakaan Nasional Bundel A. 101. Peny. Sanwani. Jakarta, 1186 H./1772 M.

Naskah Arab/Manuskrip. Taj al Asrar fi Tahqiq Masyarib al Arifin, Perpustakaan Nasional Bundel A. 101. Peny. Sanwani. Jakarta, 1186 H./1772 M.

Naskah Arab/Manuskrip. Zubdat al Asrar fi Tahqiq Ba'dha Masyarib al Akhyar. Perpustakaan Nasional Bundel A. 101. Peny. Sanwani, Jakarta, 1186 H./1772 M. Lihat juga Naskah yang sama dalam Solichin Salam. Penerbit Yayasan Pembina Generasi Penerus Indonesia (YPGPI) bekerjasama Gema Salam. 1994.

Puang Rama, S. Djamaluddin Assegaf. 1994. Penyebaran Ajaran Syaikh Yusuf di Sulawesi Selatan. Makalah Seminar Nasional diselenggarakan oleh Universitas Hasanuddin Ujung Pandang.

Riyanto, Armada. "Etika Mati di Aushcwitz dan Gaza”. Dalam Kompas. 17 Januari 2009.

Transtv. Syaikh Yusuf dalam Jejak Langkah. Jakarta. 31 Maret 2007. 



\section{INDEKS}

A

Abd Qadir 21

Abdul Bashir Dharir 28

Abdul Fathi 28

Abdul Fattah 25

Abdul Jabbar Khatib Bungsu 20

Abdul Kadir 5, 188

Abdul Karim 38, 40, 41, 158, 170,183

Abdul Karim Qutbuddin 40

Abdul Madani 32

Abdul Qadir Jailani 38, 40, 73, 158,170

Abdul Qadir Karaeng Majenneng 28

Abdullah Allamatuttahir Assegaf 30

Abdullah Muhammad Abdul Baqi al-Yamani 31

Abdullah Muhammad Assayati Annakasa 31

Abdurrahman Jami 38, 158

Abu Ayyubi 31, 32

Abu Darda 39

Abu Said Hasan 155

Abu Utsman 158

Abu Yazid 158
Afrika Selatan 6, 7, 27, 29, 43, $85,105,106,111,169$, 197

Ali Engineer 5, 176

Allah 10, 19, 32, 33, 34, 35, $36,37,39,40,47,48$, $49,50,51,52,54,55$, $56,57,59,60,61,62$, $63,64,66,67,68,70$, $71,72,73,74,76,78$, $79,80,84,85,87,88$, $89,92,93,97,109,150$, $151,152,153,154,158$, $164,167,170,192,194$

Althuser 160, 177

Ammatowa 14

Andalusia 44

Ateisme 47

Athena 124, 125

Azyumardi Azra 4

B

Babylonia 122

Baghdad 31, 44, 158

Banten 7, 9, 22, 24, 25, 27, 28, 29, 104, 111, 169 


\section{Agama dan Bayang-Bayang Etis Syaikh Yusuf Al-Makassari}

Belanda 9, 24, 27, 28, 29, F $104,105,106,111$

Bernadib 151, 165, 178

Bertens 153, 178

Bertrand Russel 123

Bugis 13, 14, 15, 16, 17, 18, $19,100,101,102,104$, $175,176,177,185,187$, $189,190,198$

Bulukumba 101

Burhanuddin 26

C

Cape Town 19, 27, 29, 105, $106,178,198$

Cawidu 20, 33, 43, 44, 69, 85, 111,197

Charles Darwin 127

D

Daeng Ri Tasammang 22

Damaskus 19, 22

Demak 15

Descartes 130, 131

\section{E}

Eksistensi 141, 187

Eksistensialisme 141, 187

Emmanuel Levinas 142

Ensiklopedi Islam 84

Epistemologi 116, 180, 193, 197

Eropa 133

Etika Bisnis 5, 185

Etika Kebidanan 5, 192

Etika Lingkungan 5, 165, 184

Etika Politik 6, 181

Etika Profesi 5, 188

Etika Religius 97, 194

Filsafat Ketuhanan 154

Formalisme 138

Francis Bacon 118, 126

Futuhat 32, 45, 195

G

Galigo 13, 14, 15, 18, 185, 190

Gallarang Moncong Loe 21

Gelar 19

George Edward Moore 136

Gowa 7, 9, 13, 15, 16, 17, $18,19,21,22,23,24$, 27, 28, 99, 100, 102, 104, $105,106,175,191$

Granada 44

Gujarat 26

H

hadits $38,39,49,54,55,62$, $68,89,90$

Hadramaut 22, 26

Hakikat 58, 61, 86, 117, 151, $170,184,195$

Hallaj 80, 158

Hamka 27

Hans Jonas 147

Haramayn 22

Haryatmoko 6, 148, 181

Hizbut Tahrir 114

Hujurat 10

Humanisme Barat 110

Humanisme Islam 167, 181, 186

I

Ibn Arabi 44, 63, 69, 170

Ibn Miskawih 170

Ibnu Rusyd 118 
Ibnu Sina 96, 118

Ibrahim Hasan 31, 32

IImu Ilahi 61

Imam Syafi'i 22, 23

Insan Kamil 94, 95, 179, 182

Iskandar Agung 124

\section{J}

Jalaluddin Rumi 74, 157

Jazirah Arab 23, 26

Jean-Paul Sartre 141

Jihad 8, 86, 105, 178, 190

Jumadil Awal 104

K

Kaelan 12, 165, 184, 197

Kaidah 121, 179

Kajang 14, 101

Kanisius 5, 97, 109, 134, 136, $154,180,189,190,192$, 193, 194, 195

Karaeng Galesong 21

Kartanegara 86, 184

Khalawaty 19

Khatib Sulung 101

Khawarizmi 118

Khazanah 96, 175

Kosmosentris 165

\section{L}

Lenin 160, 177

Lontara Attorioloang 104

Lontara Bilang 104

Lontara Pabbura 104

Lontara Sejarah 104

Lukmanul Hakim 86, 105, 178

Luwu 15, 17, 18, 102, 103

Lyceum 124

M

Madinah 22, 26, 31, 99, 115

Mahasin Hadiyatullah 20

Mahmud Abdul Qadir 24

Majalawi Makassar 19

Majelis 114, 198

Makah 22, 24, 26, 31, 38, 60, $99,115,180$

Makasar 33, 43, 87, 195

Makrifat 65, 66, 70

Malaka 15

Mangemba 8, 19, 23, 25, 29, 186, 198

Manjalawi 21

Masnawi 158

Matalib Salikin 34, 196, 199

Matoa 17, 103

Mattulada 14, 15, 16, 28, 99, 187

Maulana Muhammad Baqi 31

Max Scheler 138

Melayu 29, 100, 103, 106

Metafisika 2, 38, 125, 185

Misbahul Arwah 40, 51, 183

Mistisisme 44, 188

Mitologi 128

mubalig 16, 30, 104

Mughal 44

Mujahidin 114

Mukashafa 50

Munjiyyat 37, 197

Mursalah 19

N

Naksabandi 31

Nalar 86, 154, 184

Naskah 32, 33, 34, 35, 37, 53, $89,197,198,199$ 
Naturalisme 137

Naziat 71

Negara 189

Nietzsche 166, 188

Nihayat 36, 60, 64, 197

Nil 2, 122, 134, 138, 139, 140, 149,152

Norma 5, 6, 175, 185, 189

Nusantara 5, 7, 15, 20, 26, 44, $99,112,169,173,177$, $181,184,188,197$

\section{0}

Omar Ali 46, 194

Ontologi 116, 193

Organon 125, 126

\section{P}

Palestina 3

Paradigma 12, 165, 184

Pemikir 2, 38, 185

Persepsi 76

Persia 44, 155, 156, 157, 158, 182

Petta Sekkangnili 15

Plato 2, 38, 72, 124, 130, 185

Poespoprodjo 160, 190

Politik 6, 181, 186

Portugis 15, 24, 100

Poso 114

Profesi 5, 188

Puang Matoa 102, 103

Puritanisme 156

Purwadaksi 20, 190

Q

Quraisy 19, 27, 31

Qurratul Ain 35, 196
Qusyairi 155, 158, 188

Qutbuddin 40

$\mathbf{R}$

Radikalisme 4, 113, 197

Raja Bone 103

Raja Gowa 19, 22, 23, 27, 100, 102, 104

Raja Luwu 102

Raja Tallo 102, 103, 104

Revolusi Industri 134

Risalah Gayat al-Ikhtisar wa Nihayat al-Intizar 60

Robert Franger 44, 52

Romawi 123

Rusia 160

\section{S}

Sailaniyyah minal Futuhat 45, 195

Salik 49, 54

Saweri Gading 18, 103

Saylaniyyah 47

Sayyid Baa Alwi Assegaf 22

Sirrul Asrar 35, 196, 199

Socrates 65, 72, 109, 189

Sufisme 72, 73, 156, 157

Sulaiman Ibnu Mansur 38

Sulawesi $6,13,14,15,16,17$, $19,20,22,23,99,100$, $101,102,169,179,187$, 189, 199

Sultan Alaudin 21

Sultan Bone 27

Sultan Gowa 105

Sultan Hasanuddin 23, 27

Sultan Iskandar Muda 25

Sultan Iskandar Tsani 25

Sultan Johor 17

Suluk 51, 55, 183 


\section{Indeks}

Surek Galigo 15

Suria Sumantri 116, 119, 121, $123,130,132,133,135$, $178,179,182,188,191$, 193, 195

Syattariyah 23, 26, 32

Syiah 44, 157, 158

Syura 74

\section{$\mathbf{T}$}

Tahqiq Masyarib 35, 199

Tahsilul Inayat 36, 197

Tarekat 25, 26, 27, 28, 31, 32, 52,53

Tasawuf 8, 32, 46, 67, 99, 134, 176, 187, 188, 193

taubat $51,55,84$

tauhid 18, 23, 33, 34, 37, 40, $47,48,51,76,109,161$, 166

Teologi 151, 176, 192

Teori 9, 125, 142, 160, 170, 190

Theory 191

Thomas Arnold 100

Timur Tengah 26, 45, 177

Timur Wajo 17

Toraja 17, 102

Toshihiko Izutsu 9, 10

Transformasi 6

Tuan Rappang 28
Tudjimah 9, 25, 32, 33, 34, $35,36,37,43,45,47$, $52,53,58,59,62,85$, 87, 89, 91, 195, 196, 197 Tuhfatul Amr fi Fadlilat 37, 197

U

Ulama 7, 24, 43, 100, 106, 177, 181, 191, 197 Universalisme Islam 84

V

VOC 27,28

W

Wahyu 154, 182

Wajo 16, 17, 103

Washiyyat 37, 197

Y

Yaman 22, 26, 31, 32

Yunani 2, 64, 65, 118, 122, $123,124,125,126,127$, $133,155,156,169$

Z

Zikir 48

Zuhud 91, 92, 111 



\section{Biodata Penulis}

Mustari Mustafa. Lahir di Siru Manggarai Barat NTT, 30 September 1971. Putra dari bapak/ibu H. Mustafa Ibrahim dan Hj. Semia. Pendidikan dasar dan menengah pertama ditamatkan di Nangalili, Manggarai Barat, dan SLTA pada Madrasah Aliyah Negeri di Ende NTT. Menyelesaikan pendidikan S1 jurusan Komunikasi dan Penyiaran Islam di UIN Alauddin Makassar tahun 1995. Selanjutnya tahun 2000 menyelesaikan Pendidikan Magister jurusan Sosiologi di Universitas Negeri Makassar, dan tahun 2009 menyelesaikan Program Doktor Filsafat di Pascasarjana Fakultas Filsafat Universitas Gadjah Mada Yogyakarta.

Adapun aktivitas yang pernah dijalani penulis, di antaranya adalah menjadi pengurus senat Fakultas Dakwah IAIN Alauddin tahun 1992, Ketua Himpunan Mahasiswa Islam (HMI) Cabang Makassar tahun 1993, Pengurus Komite Nasional Pemuda Indonesia Kota Makassar tahun 1994, Direktur Lembaga Dialog (Forlog) Antarkita Sulawesi Selatan tahun 2010-sekarang, Koordinator Jaringan Interfeith se-Sulawesi (JIS) tahun 2011-sekarang, Direktur Kajian Keagamaan Pimpinan Kolektif Majelis wilayah KAHMI Sulawesi Selatan tahun 2010-sekarang, snggota badan pengurus harian bidang ibadah Masjid Al-Markaz Al-Islami Makassar tahun 2010-sekarang. 
Sejak tahun 1997, menjadi dosen tetap Fakultas Dakwah dan Komunikasi serta Pascasarjana Universitas Islam Negeri Alauddin Makassar. Dosen tidak tetap pada Program Magister Agama Universitas Al Khaerat Palu, STAIN Pare-Pare, STAIN Ambon, STAIN Ternate. Ketua penyunting Jurnal Tabligh Fakultas Dakwah dan Komunikasi UIN Alauddin tahun 2011-selesai, Wakil Ketua Ikatan Alumni Fakultas Dakwah dan Pengurus Ikatan Alumni UIN Alauddin tahun 2010-sekarang. Pernah menjadi sekretaris jurusan Pengembangan Masyarakat Islam tahun 1999-2000, ketua bidang Program Laboratorium Dakwah Fakultas Dakwah dan Komunikasi UIN Alauddin Makassar. Karya ilmiah yang dihasilkan antara lain: Agama dalam Bayang-Bayang Etika (penulis, 2010); Dakwah Kaum Sufi (penulis, 2010); Kami Bukan Fundamentalis (sedang dalam proses cetak) Begawan Jadi Presiden: Catatan Untuk Pencapresan Nurcholish Madjid (editor, 2004); Pembaharuan Pemikiran Islam di Indonesia (editor, 2006); Syari'ah Demokratik (editor, 2006); Historiografi Haji Indonesia (editor, 2007); Dakwah di Lintas Batas: Menjawab Problematika Dakwah Kekinian (editor, 2009). Karya lain yang berupa tulisantulisan untuk jurnal, baik lokal, nasional, maupun internasional, di antaranya Jurnal Transformation: School of Social Sciens Kuala Lumpur, Jurnal Civilization ICCS Kuala Lumpur. Hingga saat ini, penulis juga sering menghasilkan tulisan lain yang berupa artikel di koran-koran di Makassar. 